Doktori $(\mathrm{PhD})$ Értekezés

dr.jur. Sziebig Orsolya Johanna LL.M.

\title{
A vadvilággal kapcsolatos büntetendő cselekmények nemzetközi jogi keretei
}

\section{The International Legal Frameworks of Wildlife Crime}

\author{
Szegedi Tudományegyetem \\ Állam- és Jogtudományi Doktori Iskola
}

Témavezető:

Prof. Dr. Blutman László, tanszékvezető egyetemi tanár

Szeged

2019 


\section{GS}

\section{Köszönetnyilvánítás}

Köszönöm mindenkinek, aki segitségével hozzájárult a doktori értekezésem megírásához és támogatott ebben az embert próbáló időszakban.

„A világ különleges és bonyolult, akárcsak a pók hálója.

Ha megérinted egy fonalát, remegése végigfut az összes többi szálon.

Mi nemcsak megérintjük a hálót, hanem bele is szakitunk."

(Gerald Durrell)

$\cos$ 


\section{Tartalomjegyzék}

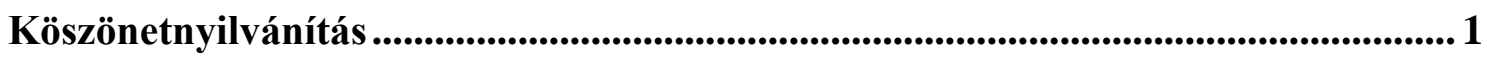

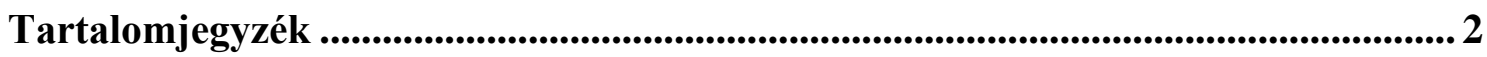

Táblázatok, ábrák jegyzéke ............................................................................................................... 4

Rövidítések jegyzéke...............................................................................................................................5

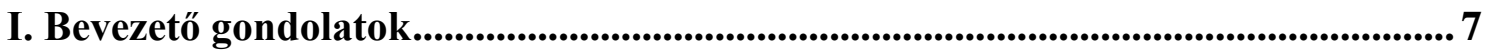

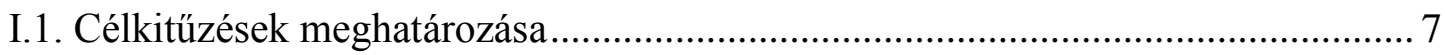

I.2. Nyelvi problémák, avagy egy új terminológia megalkotásának nehézségei ........ 15

II. A vadvilággal kapcsolatos büntetendő cselekmények jelentősége....................... 19

III. A vadvilággal kapcsolatos büntetendő cselekmények fogalmi kérdései............. 30

III.1. A környezet elleni büncselekmények …..................................................... 31

III.2. A vadvilággal kapcsolatos büncselekmények az ENSZ fogalmi rendszerében. 40

III.3. A vadvilággal kapcsolatos büntetendő cselekmények fogalmi elemei és jellemzői

III.3.1. Az állami büntetőjog szerepe, a büntetni rendelés................................. 49

III.3.2. A szervezett bünözés és a súlyos büncselekménynek minősítés .................52

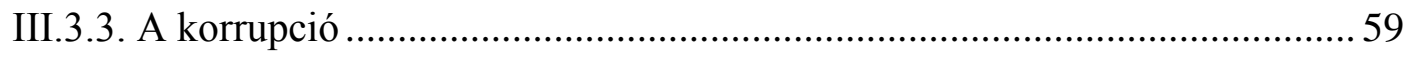

III.4. A vadvilággal kapcsolatos büncselekmények jellemzői ................................... 62

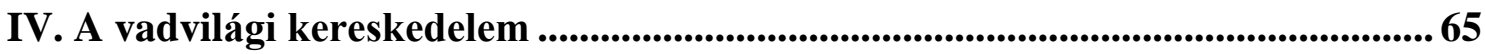

IV.1. A CITES helye a nemzetközi környezetvédelmi jogban.................................. 74

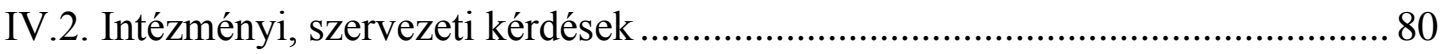

IV.3. A vadvilági kereskedelmet szabályozó nemzetközi egyezmény kritikai vizsgálata

IV.3.1. Kezdeti problémák és a hatékonyság kérdése 93

IV.3.2. A CITES szabályozási rendszere - a Függelékekkel kapcsolatos problémák

feltárása egy esettanulmányon keresztül. .97 
IV.3.3. A CITES-hez füzött fenntartások hatása a fajok védelmére 108

IV.3.4. A CITES végrehajtása és érvényesülése az államokban - megfelelés az Egyezmény által támasztott kötelezettségeknek 116

IV.3.4.a) Megfelelőségi kérdések 119

IV.3.4.b) „A nem felelt meg minősítés” - kereskedelmi felfüggesztések. 125

IV.3.4.c) A nemzetközi kereskedelmi jog kapcsolódási pontjai a Washingtoni Egyezményhez 128

IV.4. A hátrányos jogkövetkezmények alkalmazása 140

V. Az Európai Unió vadvilági kereskedelemre vonatkozó szabályozása 148

V.1. A vadvilági kereskedelem jelentősége az Európai Unióban 151

V.2. Az Európai Unió csatlakozása a Washingtoni Egyezményhez 156

V.3. Az Európai Unió vadvilági kereskedelemre vonatkozó normái 159

V.3.1. A szabályozás kezdeti lépései és módosításai 159

V.3.2. Wildlife Trade Regulations, az Európai Unió vadvilági kereskedelemre vonatkozó rendeletei és döntései 162

V.4. Föbb különbségek a CITES és az EU vadvilági kereskedelemre vonatkozó szabályozása között. 166

V.5. A bürokrácia útvesztői - vadvilági kereskedelem a belső piacon és harmadik államokkal

V.5.1. Fogalmi alapvetések

V.5.2. A megfelelő dokumentáció követelménye 173

V.5.3. Behozatal az Európai Unió területére 175

V.5.4. Az Európai Unión belüli kereskedelem 180

Konklúzió: a vadvilággal kapcsolatos büntetendő cselekmények elleni küzdelem eszközei - sarokpontok a védett fajok megőrzésében. 184

Záró gondolatok 192

Irodalomjegyzék 193 


\section{Táblázatok, ábrák jegyzéke}

1. sz. ábra Összefüggések bemutatása 62. p.

1. sz. táblázat Terminológia 18. p.

2. sz. táblázat Fenntartások az I. és II. Függelékekhez 114. p.

3. sz. táblázat $\quad$ Az uniós tagállamok csatlakozása a CITES-hez 158. p.

4. sz. táblázat Dokumentációs követelmények az Európai Unióban 183. p. 


\section{Rövidítések jegyzéke}

CITES (Convention on International Trade in Endangered Species of Wild Fauna and Flora): Washingtoni Egyezmény a veszélyeztetett vadon élő állat- és növényfajok nemzetközi kereskedelméről

CoP(s) (Conference(s) of the Parties): Részes felek konferenciája (konferenciái)

CTE (Committee on Trade and Environment): Kereskedelmi és Környezeti Bizottság (értekezésben: WTO-hoz kapcsolódóan)

ECJ (European Court of Justice): Európai Bíróság

ENSZ (United Nations): Egyesült Nemzetek Szervezete

EU (European Union): Európai Unió

FAO (Food and Agricultural Organisation): ENSZ Élelmezésügyi és Mezőgazdasági Szervezete

IATA (The International Air Transport Association): Nemzetközi Légi Szállítási Szövetség

ICC (International Criminal Court): Nemzetközi Büntetőbíróság

ICCWC (The International Consortium on Combating Wildlife Crime) A vadvilágot érintő büncselekmények ellen fellépő nemzetközi konzorcium

ICJ (International Court of Justice): Nemzetközi Bíróság

IFAW (International Fund for Animal Welfare): Állatok jólétével foglalkozó nemzetközi alap

INTERPOL (International Criminal Police Organization): Nemzetközi Bűnügyi Rendörség Szervezete

ITLOS: (International Tribunal for the Law of the Sea): Nemzetközi Tengerjogi Bíróság IUCN (The International Union for Conservation of Nature): Természetvédelmi Világszövetség

MDGs (Millenium Development Goals): Millenniumi Fejlesztési Célok 
MEA (multilateral environmental agreement): többoldalú környezeti megállapodás/egyezmény

NGO (non-governmental organisation): nem kormányzati szervezet

OECD (Organisation of Economic Cooperation and Development): Gazdasági Együttmüködési és Fejlesztési Szervezet

SDGs (Sustainable Development Goals): fenntartható fejlődési célkitüzések

TOC (Transnational Organised Crime): nemzetközi szervezett bünözés

TRAFFIC (the Wildlife Trade Monitoring Network): a vadvilággal kapcsolatos kereskedelmi tevékenység megfigyelésével foglalkozó hálózat

UNCAC (The United Nations Convention against Corruption): az ENSZ Korrupció elleni egyezménye

UNEP (United Nations Environment Programme, UN Environment): ENSZ Környezeti Programja

UNESCO (United Nations Educational, Scientific and Cultural Organization): Az ENSZ Nevelésügyi, Tudományos és Kulturális Szervezete

UNODC (United Nations Office on Drugs and Crime): Az ENSZ Kábítószer-ellenörzési és Bünmegelőzési Hivatala

WTO (World Trade Organisation): Kereskedelmi Világszervezet

WWF (World Wildlife Fund for Nature): Természetvédelmi Világalap 


\section{Bevezető gondolatok}

\section{I.1. Célkitűzések meghatározása}

„A földi élet jövője attól függ, hogy képesek vagyunk-e cselekedni. Sokan egyénileg is megtesznek minden tölük telhetöt, ám valódi sikert csak akkor érhetünk el, ha gyökeres változások mennek végbe a társadalomban, a gazdaságban és a politikában." 1

A biológiai sokféleség csökkenése napjaink egyik legfontosabb környezetvédelmi kérdése. A biodiverzitás megőrzésének egyik eszköze a veszélyeztetett fajok védelme. A veszélyeztetett fajok számáról megbízható információként szolgál az IUCN vörös listája, amely szerint mintegy 26500 fajt fenyeget a kihalás. ${ }^{2}$ Az IUCN által vezetett lista jelentősége továbbá, hogy információt és segítséget biztosít a multilaterális környezeti egyezmények felülvizsgálatához, így a CITES függelékeibe való sorolás során is használatos. ${ }^{3}$ A fajok fennmaradását nagyban veszélyeztetik az olyan tevékenységek, mint a természetes élőhelyek pusztítása és a globális felmelegedés következtében kialakuló negatív hatások. Azonban a fokozott extinkció egyik vezető oka a fajok gazdasági célzatú kizsákmányolása. A fajok pusztulása alapvetően természetes jelenség az élővilágban, de az utóbbi évszázadok, különösen a XX. század emberi tevékenysége azt eredményezte, hogy a természetes kihalás rátájánál sokkal nagyobb számú, évente mintegy 5-20 ezer közötti faj tünik el. Amennyiben ez a tendencia folytatódik, az összes faj mintegy 10 százalékát fenyegeti a teljes kihalás. ${ }^{4}$ Veszélyeztetettnek hívjuk azokat a fajokat, amelyeket a kihalás veszélye fenyeget, tehát fennmaradásuk nem biztos. Utóbbi általában két tényező eredménye. Egyrészről az ún. élőhelypusztítás, másrészről pedig a vadvilág nem fenntartható kizsákmányolása, kiaknázása. Az emberiség egyre több területet követel magának, például mezőgazdasági célok miatt. Így olcsó, az iparban és az élelmiszergyártás során is felhasználható olaj gyártására, pálmaültetvényeket létesítenek a trópusi őserdők helyén. A fajkihalásról szóló hírek szinte megszokottá váltak, 2019 májusában az utolsó malajziai

\footnotetext{
${ }^{1}$ Sir David Frederick Attenborough (London, 1926. május 8. -), természettudós. Idézet forrása: https://www.citatum.hu/idezet/49783 (2019. 07. 23.).

${ }^{2}$ IUCN Red List Background \& History https://www.iucnredlist.org/about/background-history (2019. 02. 16.).

${ }^{3}$ How the Re List is Used? https://www.iucnredlist.org/about/uses (2019. 07. 23.).

${ }^{4}$ BÁLDI ANDRÁs: Természetvédelmi biológia: a biodiverzitás megörzésének tudománya. Magyar Tudomány, 2006/6, 650. p. http://www.matud.iif.hu/06jun/02.html (2019. 03.24.).
} 
hím szumátrai orrszarvú haláláról olvashattunk. ${ }^{5}$ Talán az egyik legmegdöbbentőbb esemény a vándorgalambok ${ }^{6}$ eltünése volt 1914-ben, amelyről egy centenáriummal később híres tudományos bestseller is íródott „Üzenet Martha-tól: Tanulságok a kihalt vándorgalambról " címmel. ${ }^{7}$ A huron indiánok által szent állatként tisztelt vándorgalamb egykoron Észak-Amerika és a világ legnépesebb madárfaja volt, több százmilliós egyedszámmal. Az indiánok a költési időszakokra és a költőhelyek fennmaradására figyelemmel vadászták őket, azonban a telepesek a magevő madarakat a húsáért vadászni, a mezőgazdasági területek védelme miatt pedig írtani kezdték. Végül a természetes élőhelyek csökkenése eredményeképpen az egyedszám rohamosan csökkeni kezdett és a természetvédelmi erőveszítések már nem tudták megmenteni a fajt. A vándorgalamb azonban beírta magát a természetvédelmi szabályozás történetébe azzal, hogy az első természetvédelmi törvény elfogadásának egyik fó indoka éppen a galambok védelme volt. John F. Lacey $^{8}$ képviselő kongresszusi beszédében kifejtette: ,a vándorgalamb, amely korábban több milliós csapatokban vándorolt, mára eltünt a Föld színéröl. Szörnyü példáját szolgáltattuk a mészárlásnak és rombolásnak, ami az egész emberiség számára intő jel lehet. Adjuk most példáját a bölcs védelemnek, hogy a természet megmaradt javait megóvjuk." "9 Bár a szabályozás nem menthette meg őket, példájuk örök elrettentésként szolgál, hogy az ember miként határozhatja meg egy faj sorsát.

Napjainkra a környezettel szimbiózisban élő közösségek helyét nagyobb részben átvették az urbanizált társadalmak. Az urbanizációnak önmagában is negatív hatása van a környezetre, többek között meg lehet említeni a koncentrált levegőszennyezést és hulladéktermelést, a természeti közeg megváltoztatását az iparosodás és városi fejlesztések érdekében. ${ }^{10}$ A környezetszennyezés olyan újabb tényező, amely negatív hatással van a természetes élővilágra. Különösen az ipari forradalom óta eltelt időszak technológiai újításai

\footnotetext{
${ }^{5}$ A szumátrai orrszarvú az egyik legveszélyeztetettebb fajnak számít a világon, az intenzív orvvadászatnak és élőhelypusztításnak köszönhetően körülbelül 80 vadon élő egyed maradt. Malajziában „Tam” volt az utolsó, fogságban tartott hím példány. A faj megmentésére nemzetközi összefogás kezdődött, de annak túlélése így is csekély esélyekkel kecsegtet.

Forrás: Jason Bittel: Last male Sumatran rhino in Malaysia dies. 2019. május 27.

https://www.nationalgeographic.com/animals/2019/05/last-sumatran-rhino-malaysia-dies/ (2019. 08. 09.).

${ }^{6}$ Idegen nyelvü elnevezések: pigeon de passage (francia), passenger pigeon (angol), ectopistes migratorius (latin).

${ }^{7}$ Mark Avery: A Message from Martha: The Extinction of the Passenger Pigeon and its Relevance Today. Bloomsbury Natural History, 2014. (Martha az utolsó vándorgalamb volt, akit a Cincinatti állatkertben tartottak és 1914. szeptember 1-jén pusztult el.).

${ }^{8}$ John Fletcher Lacey (1841-1913), iowai republikánus képviselő, nevéhez füződik a Lacey Act, az Amerikai Egyesült Államok első természetvédelmi törvénye.

${ }^{9}$ Fuisz Tibor István: A vándorgalamb (ectopistes migratorius) kiirtása. 2015. december 02. https://mttmuzeum.blog.hu/2015/12/02/a_vandorgalamb_ectopistes_migratorius_kiirtasa (2019. 08. 09.).

${ }^{10}$ Urban Threats https://www.nationalgeographic.com/environment/habitats/urban-threats/ (2019. 07. 18.).
} 
vezettek ahhoz, hogy ma már kijelenthetjük, az emberiség sok tekintetben visszafordíthatatlan károkat okozott a Földön. Visszautalva az egyik gondoltara: a fajok fennmaradását veszélyezteti a kizsákmányolás. Számos állat- és növényfajt gazdasági célból vadásznak, gyüjtenek, vágnak ki, hasznosítanak. A természeti közeg, a „vadvilág” kiaknázása mindig is magától értetődő volt az emberek, a közösségek számára. Azonban a korábban már említett természetközeli népek a fenntarthatóság elvei alapján használták ki a rendelkezésre álló erőforrásokat, amelyeket a természet kínált. A probléma akkor kezdődött, amikor ez a „,bevétel, begyüjtés” meghaladta a fenntartható mértéket, vagyis az élővilág már nem tudta újratermelni önmagát. A gazdaság kifejezéseivel élve, a kereslet nagyobb lett, mint a kínálat. Azonban amíg egy gyártósoron készült hiánycikk néhány hónapon, akár pár napon belül pótolható, ha egy élő organizmus eltünik a Föld színéről, az már sohasem tér vissza. A fajkihalás alapvetően természetes jelenség, de az elmúlt néhány évtizedben sohasem látott extinkciós rátáról számolhatunk be.

Az elöbbi problémák miatt jutott szerephez a jog a fenti területen, hiszen mind az állami szintü, mind a nemzetközi szintü szabályozásban igyekeztek olyan normákat alkotni, amelyek védik a biológiai sokféleséget, a fajokat. A nemzetközi közösség az 1960-as évektől kezdődően tárgyalt arról - a civil szektor sürgető támogatásával - milyen formában lehetne a vadvilágból származó termékek/egyedek kereskedelmét szabályozni. Ennek a diskurzusnak az eredményeképpen kötötték meg a Washingtoni Egyezményt, amelynek öt betüből álló rövidítése - CITES - világszerte ismertté vált, 1973-as aláírása óta. ${ }^{11}$ Mindazonáltal a kezdetben nehezen induló, majd erőre kapott és végül újra problémákkal küzdő egyezményrendszer a legjobban müködő multilaterális környezeti megállapodások közé sorolható. Ugyanakkor - ahogyan az értekezés későbbi fejezeteiben bizonyítom számos kritikai észrevétel is megfogalmazódott az Egyezménnyel szemben. A XXI. század első két évtizede nem várt kihívásokat, nem sejtett aggodalmakat hozott a vadvilág megörzésében, és a már korábban alkotott nemzetközi jogi instrumentumoknak adaptálódni kell ezekhez a változásokhoz.

\footnotetext{
${ }^{11}$ Convention on International Trade in Endangered Species of Wild Fauna and Flora. Egyezmény a veszélyeztetett vadon élő állat- és növényfajok nemzetközi kereskedelméröl. 1973. (1975.) Kihirdette: 2003. évi XXXII. törvény [Magyarország vonatkozásában 1985. augusztus hó 27. napján lépett hatályba.] Megjegyzés: az értekezésben a CITES és a Washingtoni Egyezmény, valamint az Egyezmény kifejezéseket a szerző szinonimaként használja.
} 
A következőkben röviden összegzem az értekezés fö célkitüzéseit és feltevéseit.

- Terminológiai problémák rendezése.

A téma vizsgálata során a kutató mindjárt azzal a kihívással szembesül, hogy jelenleg a magyar szakirodalomban nincsen elfogadott megfelelöje az olyan angol terminológiának, mint a „,wildlife crime”, ,wildlife trade”, ,wildlife products”. Így elsődleges célkitüzésem egy olyan megfelelö fordítás kidolgozása, amely mind a tartalmi, mind a nyelvhelyességi szempontoknak megfelel és jól alkalmazható. A bevezető gondolatok végén részletesen elemzésre kerülnek az egyes fordítási lehetőségek, kialakítva az értekezésben használt elnevezéseket.

- A vadvilággal kapcsolatos büntetendö cselekmények rendszertani szempontból elhelyezhetök a környezet elleni büncselekmények körében és azok egyik tipikus megvalósulási formája a jogellenesen folytatott kereskedelmi tevékenység.

Bár a magyar szakirodalom is foglalkozik a környezeti büncselekményekkel, azok egyik legfontosabb megvalósulási formái, a vadvilággal kapcsolatos büntetendő cselekmények, a vadvilági kereskedelem kevéssé ismertek annak ellenére, hogy a nemzetközi környezetvédelmi diskurzus főszereplőivé váltak az utóbbi évtizedben. Ugyanakkor az értekezés keretében nem célom az összes környezeti büncselekmény részletes elemzése.

- A vadvilággal kapcsolatos büntetendö cselekmények fogalmának és jellemzöinek meghatározása.

Jelenleg nincsen nemzetközi szinten elfogadott definíciója az ún. „,wildlife crime” jelenségnek, bár az egyes fogalmi elemek azonosíthatók a nemzetközi szervezetek és vonatkozó nemzetközi egyezmények segítségével. Rendszerezem a vonatkozó határozatokat, megállapodásokat, eszközöket, amelyeket a nemzetközi közösség a vadvilággal kapcsolatos büncselekmények témakörében alkalmaz. Az értekezés egyik központi eleme annak a kérdésnek a megválaszolása, hogy egyáltalán lehetséges-e egységes fogalomalkotás, vagy csak azok a fő elemek állapíthatók meg, amelyek általában véve jellemzik a vadvilággal kapcsolatos büncselekményeket. 
- A vadvilággal kapcsolatos büntetendö cselekmények és a határon átnyúló szervezett bünözés közötti kapcsolat feltárása.

A vadvilágot károsító cselekmények sok esetben megmaradnak az egyes államok területén belül (például az orvvadászat), azonban a szervezett bünözői csoportok térnyerése a környezeti bűncselekmények elkövetése során, új kihívások elé állítja a bünüldöző szerveket. A jogellenes vadvilági kereskedelem biztosítja, hogy a sokszor szintén illegális módon megszerzett vadvilágból származó termékek, egyedek eljussanak a végső vásárlóhoz. Így a téma szempontjából nélkülözhetetlen a határon átnyúló szervezett bünözés és a vadvilággal kapcsolatos büntetendő cselekmények, különösen a jogellenes kereskedelmi tevékenység közti kapcsolódás meghatározása, a vonatkozó nemzetközi jogi instrumentumok értékelése.

- A jogellenes vadvilági kereskedelem - a vadvilágból származó egyedek, illetve azokból készült termékek kereskedelme - a biodiverzitás megörzése érdekében tett eröfeszítések egyik legnagyobb akadálya.

A vadvilággal kapcsolatos büntetendő cselekmények tipikus megvalósulási formája amely már nemzetközi jelleget hordoz - a jogellenes vadvilági kereskedelem. A vadvilági kereskedelem alapvetően nem tilalmazott, számos állam egyik fő bevételi forrását jelenti. Amennyiben az veszélyeztetett, vadon élő fajokkal történik, a kereskedelem a CITES tárgykörébe tartozik, éppen ezért kiemelkedő jelentőséggel bír a Washingtoni Egyezmény.

- A CITES kritikai szemléletü vizsgálata.

A Washingtoni Egyezmény az egyik legjobban müködő rendszert hozta létre, ha a multilaterális környezeti egyezményeket szemléljük. Azonban több szempontból - hatékonyság, a szabályozás módja, a függelékek rendszere - kritika fogalmazható meg a CITESel szemben.

- Egy releváns esettanulmányon keresztül szemléltetni a CITES-hez kapcsolódó függelékek hatását a vadvilággal kapcsolatos büncselekményekre és a fajok fennmaradására.

A CITES által biztosított védelem szintje abban mutatkozik meg, hogy az adott faj az Egyezmény melyik Függelékében (I. - II. - III.) kerül listára. Azonban a kritikai 
észrevételek egy jelentős része azért fogalmazódott meg, hogy a CITES pusztán politikai jellegü eszköz az államok kezében és azon fajok esetében, amelyek jelentős gazdasági értékkel rendelkeznek, nem nyerhető el az államok támogatása.

- A kereskedelmi felfüggesztések összeegyeztethetöségéröl való értekezés, tekintettel a WTO szabályozására és a nemzetközi kereskedelmi jogra.

A téma multidiszciplináris jellegéből adódik, hogy a nemzetközi kereskedelmi jog egyes aspektusai is felmerülnek, különösen a CITES nyomán alkalmazandó kereskedelmi felfüggesztések összeegyeztethetősége a nemzetközi kereskedelmi joggal. Előzetes feltevésként kijelenthető, hogy megállapítható az összeegyeztethetőség, azonban részletesen elemzem a vonatkozó problémákat.

- A nemzetközi szerzödési jogi aspektus elemzése - a Washingtoni Egyezményhez füzött fenntartások hatása a fajok védelmére.

A nemzetközi egyezményekhez füzött fenntartások kérdésköre egy újabb téma, amely a CITES hatékonyságával kapcsolatosan felmerül. A fenntartások több esetben is az Egyezmény gyakorlati érvényesülését akadályozták és rendszeresen akkor kerülnek alkalmazásra, ha az érintett fajok gazdasági hasznot hoznak az államoknak. Tekinthetünk-e tehát a fenntartásokra a Washingtoni Egyezmény kapcsán, mint az államok kibúvójára a fajok védelme alól?

- A vadvilággal kapcsolatos büntetendö cselekmények és az egyéni felelösség kérdésének elemzése.

Alapvetően a környezeti büncselekmények gyüjtőfogalmába tartozó cselekményekért való egyéni büntetőjogi felelősség megállapítása megmarad az államok igazságszolgáltató szerveinek kezében. Bár számos multilaterális környezeti tárgyú egyezmény esetében találhatunk hátrányos jogkövetkezményekre vonatkozó szabályokat - ez alól a CITES sem kivétel - azok a nemzeti szintü jogalkotásra bízzák a részletek kidolgozását. Több állam esetben nem is beszélhetünk büncselekményi minősítésröl. A különböző jogkövetkezményeknek, legyenek azok polgári jogiak, büntetőjogiak vagy közigazgatási jellegüek, mind megvannak a sajátos funkciói a környezetet károsító cselekmények szankcionálásában. Mivel a nemzetközi közösség számára egyre sürgetőbb problémát jelentenek a környezet elleni büncselekmények, a formálódó nemzetközi büntetőjog a jövőben eljuthat egy önálló kategória megalkotásáig. Azonban napjainkban ilyen, környezeti 
tárgyú nemzetközi büncselekményröl nem beszélhetünk annak ellenére, hogy a Nemzetközi Büntetőbíróság gyakorlata is egyre nagyobb figyelemmel van a környezetkárosító cselekményekre.

- Az Európai Unió vadvilági kereskedelemre vonatkozó szabályozásának elemzése, az Európai Unió, mint részes fél a Washingtoni Egyezményben.

Az EU volt az első, az Egyezmény rendszerében „,regionális gazdasági szervezetnek” hívott entitás, amely részes féllé vált az Egyezményben. A részletes elemzés további indoka, hogy a vadvilági kereskedelem egyik „ütközőzónája” az Európai Unió területe, ahol a belső piac további nehézségek elé állítja az államokat.

Az vadvilággal kapcsolatos büntetendő cselekmények transzszisztematikus, multidiszciplináris jellegéből adódóan az értekezés felépitése az egyes vonatkozó jogterületeket és jogágakat követi. Az értekezésben megtalálhatóak a nemzetközi környezetvédelmi jogi, nemzetközi kereskedelmi jogi, büntetőjogi és nemzetközi büntetőjogi, uniós jogi és nemzetközi közjogi elemek is.

Az értekezés először a vadvilággal kapcsolatos büntetendő cselekményekkel, mint jelenséggel foglalkozik, feltárva annak jelentőségét a fajok fennmaradására és az egyes államok környezeti, társadalmi, valamint gazdasági helyzetére. A következő fejezet a fogalmi kérdéseket veszi sorra, amely keretében a rendszertani hely tisztázása után, az egyes fogalmi problémák taglalása történik. Az egyes fogalmi elemek is kibontásra kerülnek, különös tekintettel és részletező jelleggel a határon átnyúló szervezett bünözés, valamint a vadvilággal kapcsolatos büntetendő cselekmények összefüggéseinek megvitatására. Utóbbi két tárgykörben a releváns nemzetközi egyezmények is vizsgálat tárgyát képezik. A kormányközi nemzetközi szervezetek - többek között az ENSZ föszerveinek és a UNEP-nek - a határozatai, döntései is a tanulmányozás tárgyai közé tartoznak. Utóbbiak esetében is megfigyelhető, hogy az egyes - büntetőjogi, környezetvédelmi és környezetvédelmi jogi, kereskedelmi jogi és nemzetközi közjogi - elemek keverten kerülnek taglalásra.

Kitekintés történik a „hátrányos jogkövetkezmények” körére, az individuális büntetőjogi felelősségre, a Nemzetközi Büntetőbíróság legújabb felfogására a környezet károsító cselekményekhez kötődően.

Átfogó jelleggel a vadvilági kereskedelemre vonatkozó nemzetközi és uniós jogi szabályozás kerül elemzésre, amely jogellenes formája a vadvilágot károsító cselekmények 
legfontosabb nemzetközi jellegü formájának tekinthetö. A veszélyeztetett vadon élő állatés növényfajok nemzetközi kereskedelméről szóló Washingtoni Egyezmény 1973-as elfogadása óta rengeteg kihívás tépázta meg az egyébként sikeresnek tekinthető szerződéses rendszert. A CITES gyakorlatban történő megvalósítása olyan nemzetközi közjogi és nemzetközi kereskedelmi jogi kérdéseket vet, amelyeket megnyugtatóan aligha válaszolhatunk meg. Ide sorolhatók a CITES részes konferenciáin elfogadott határozatok és döntések kötőereje, a kereskedelmi felfüggesztések összeegyeztethetősége a WTO rendszerével és a fenntartások hatása a fajok védelmére.

A vadvilággal kapcsolatos büntetendő cselekmények témakörének kutatása megköveteli a multidiszciplináris kutatás- és látásmódot, az összehasonlító jellegü elemzést. A tárgykör érdekes és nehezen megítélhető jogi problémákban gazdag, amelyek feltárása, megválaszolása, kitartó mérlegelést és nemzetközi szemléletet igényel. Ugyanakkor számos olyan vonatkozó részkérdés is felmerül, amelyek nem kerülnek részletes elemzésre az értekezés keretében. Ide sorolható a biológiai sokféleség védelme érdekében alkotott egyezmények sora, az őslakos népek jogai, az államfelelősség kérdése, valamint a szabadkereskedelem és a környezetvédelem összefüggései. Mivel az értekezés elsősorban a veszélyeztetett, vadon élő fajok kereskedelmével és annak jogellenes formájával, mint a vadvilággal kapcsolatos büntetendő cselekmények egyik esetével foglalkozik, az előbb említett témakörök részletes feltárása más irányba terelte volna a dolgozatot. Így az értekezés a rendszertani-fogalmi elemzéstől kezdődően a vadvilági kereskedelem és a vonatkozó egyezmények elemzésén keresztük közelíti meg a témát, feltárva a nemzetközi európai uniós - és állami szinteket, a jogi problémákat. 


\section{I.2. Nyelvi problémák, avagy egy új terminológia megalkotásának nehézségei $^{12}$}

Kosztolányi Dezső szavaival élve: „alig akad olyan árnyalat, melyet hajlékony, rugalmas, gazdag nyelvünkön ma nem fejezhetnénk ki."

Mégis, az idegen nyelvü szakirodalom magyar nyelvbe ültetése során a tudományos munkát végző személy gyakran kerül abba a kínos helyzetbe, hogy az angol nyelvben két szóval - tömören és egyszerűen - meghatározott kifejezést nem tudja érthetően és mívesen visszaadni. Különösen problémás lehet a helyzet, ha olyan területtel foglalkozik, amelynek nincsen magyar nyelvű szakirodalma vagy a használt elnevezéseknek elfogadott fordítása. A PhD értekezés megírásakor a szembesültem az előbbiekben kifejtett akadályokkal. Az angol környezetjogi szakirodalomban használt „wildlife crime” és „wildlife trade” kifejezések a magyar jogtudománytól idegenek, azok jelentéstartalma egyszerü módon nem ragadható meg.

Némileg könnyebb a helyzet az „environmental crime” kifejezéssel, hiszen a környezeti büncselekmények, környezeti érdekeket sértő büncselekmények, vagy a környezet és természet elleni büncselekmények ${ }^{13}$ terminusok használatosak a jogirodalomban is. Az értekezésben a környezet elleni bűncselekmények elnevezést használom.

A problémás kifejezések fordítása során alkalmazhatjuk a szó szerinti átültetést, ami a következő eredményekre vezethet. A „,wildlife” fordítható vadvilágnak, természetnek, a „crime” pedig bünnek, bünténynek, vétségnek, büntettnek vagy büncselekménynek. A „wildlife” fordítását illetően mindenképpen a vadvilág kifejezés alkalmazandó, mivel a vonatkozó és a cselekményeknek hátteret adó egyezmények is elsősorban a vadvilágra és nem a tágabb értelemben vett természetre vonatoznak. Nehezebb helyzetbe ütközünk a „crime” fordulattal, mivel több jelentéssel is bír. A legtágabb értelemtől a szükebbig haladva, elsőként a bűnözés fogalma merül fel. A bünözés alapvetően ,olyan történetileg is

\footnotetext{
12 A terminológiákkal kapcsolatosan megjegyezném, hogy a korábbi publikációim és az értekezésem műhelyvitára leadott változata is a vadvilági bünözés és a vadvilági kereskedelem kifejezéseket alkalmazta, bár a szövegtörzsben megjelent a vadvilággal kapcsolatos büncselekmény fordulat is. A tanulmányok lektorálása során eddig nem kaptam visszajelzést a használt terminológia kapcsán, azonban a dolgozatom előbírálatai kitértek erre a tárgykörre. Utóbbira tekintettel és saját megfontolásból határoztam el az értekezésben használt fogalmi elnevezések elemzését és azok jobbító szándékú újítását.

${ }^{13}$ A szakirodalomban széles körben használt kifejezések:

„Környezet és természet elleni büncselekmények” In: KöHALMI LÁSZLÓ: XIX. Környezet és természet elleni büncselekmények. https://jog.tk.mta.hu/uploads/files/22_KohalmiL.pdf (2019. 07. 21.)

„Környezeti érdeket sértő büncselekmények” In: BÁNDI GYULA: Környezetjog. Szent István Társulat, 2014. „Környezet és természet elleni büncselekmények” 2012. évi C. törvény a Büntető Törvénykönyvről, XXIII. Fejezet Környezet és természet elleni büncselekmények.
} 
változó társadalmi jelenségként is felfogható, amely negatív módon jelzi, hogy egy mindenkori társadalom milyen mértékben képes biztositani zavartalan müködését, milyen módon képes átörökiteni fennmaradását és tovább fejlödését biztositó normákat. "14 Öszszegezve tehát a vadvilági vagy természeti bünözés eredményre juthatunk, amely bár szófordulat szempontjából jól használható, sajnos nem elegáns és anyanyelvünkön idegennek, nyakatekertnek hat. Ráadásul a bünözés túlságosan is széles kört ölel át, így a bünözés fogalmának használatát elvetettem. Ugyanakkor, ha a védett jogi tárgy alapján közelítjük meg a fogalmat, a vadvilági bünözés elnevezés sem lenne kizárható. Hiszen az „environmental crime” elfogadottan fordítható környezeti büncselekménynek. E logika alapján a „wildlife crime” is használható lenne vadvilági bünözésként.

Kissé megnyugtatóbb és szebb a vadvilággal kapcsolatos büncselekmények kifejezés. Utóbbit azonban hosszadalmasnak találhatjuk, szóismétléshez vezethet és nehezebb mondatokat alkotni vele. A büncselekmény fogalmát a magyar Büntetőtörvénykönyv a következőképpen határozza meg: „büncselekmény az a szándékosan vagy - ha e törvény a gondatlan elkövetést is büntetni rendeli - gondatlanságból elkövetett cselekmény, amely veszélyes a társadalomra, és amelyre e törvény büntetés kiszabását rendeli." "15

A fogalom használatával tartalmi szempontból az a probléma adódhat, hogy a vonatkozó egyezmény, a CITES nem írja elő az egyezmény megsértésével elkövetett cselekmények büncselekményi minősítését, hanem több államban ezek megmaradnak a szabálysértés szintjén. A dolgozat későbbi fejezetében még részletesen szólok az előírható jogkövetkezmények köréröl. Elöljáróban annyit jegyeznék meg, hogy a részes felek által foganatosítandó intézkedések között az Egyezmény „hátrányos jogkövetkezményekkel való sújtásról beszél", ${ }^{16}$ amely lehet akár pusztán egy közigazgatási vagy egyéb enyhe szankció, esetleg pénzbírság. A CITES eredeti, hivatalos nyelvi változatában azonban a „penalize” szó található meg, amely magyar fordítása a megbüntet, büntetéssel sújt vagy büntetendőnek nyilvánít. Utóbbira tekintettel az értekezésben a „wildlife crime” kifejezést a „,vadvilággal kapcsolatos büntetendö cselekményeknek”, illetve a „vadvilággal kapcsolatos büncselekménynek" fordítom azzal, hogy a büncselekmény kifejezést olyan államok tekintetében használom, amelyek ténylegesen így szankcionálják az Egyezmény megsértését.

\footnotetext{
${ }^{14}$ BorbíRÓ ANDREA - GÖNCZÖL KATALIN - KEREZSI KLÁRA - LÉVAY MIKLÓs: Kriminológia. Kriminológiai Elmélet: bűnözésmagyarázatok, A kortárs kriminológia tárgya és vizsgálati területei. Budapest, 2016. 235. p.

15 2012. évi C. törvény a Büntető Törvénykönyvröl 4. § (1) bekezdés.

${ }^{16}$ CITES VIII. Cikk, 1. bekezdés a) pont.
} 
A „wildlife trade” fogalmat fordíthatjuk vadvilági kereskedelemnek vagy vadvilággal kapcsolatos kereskedelmi tevékenységnek is, esetleg a vadvilágból származó fajokkal folytatott kereskedelemnek. Amennyiben a CITES fogalomkörét alkalmazzuk, a pontos elnevezés „veszélyeztetett vadon élö állat- és növényfajok kereskedelme” lenne, amely egyaránt utal azok élő és élettelen formáira és a belölük készült termékekre is. Az értekezésben a „vadon élö fajok kereskedelme” vagy a „vadvilági kereskedelem” elnevezéseket használom. A vadvilági kereskedelem önmagában nem sérti a magyar nyelv szabályait és nem is hangzik idegennek, jobban elfogadható, mint a vadvilági bünözés. Így a dolgozat szerzőjeként nem zárkózom el annak használatától.

A vadvilágból származó egyedeket, példányokat és az azokból készült termékeket sok esetben - főként fejlődő államokban - hagyományos piaci körülmények között árulják. Az érintett helyszínek elnevezése ,wildlife market”, amelyet vadvilági termékek piacának fordíthatunk. A vadvilágól származó fajokból készült termékekre a „wildlife products” kifejezéssel utalnak. Utóbbi szintén gyüjtőfogalomnak tekinthető, hiszen a vadon élő fajok bármely - többek között: gyógyászati célú, élelmezési, díszítési, divatipari - felhasználása ebbe a kategóriába sorolható. A ,product” legszélesebb értelemben vett jelentései: termék, áru, így a kifejezés leginkább vadvilági termékeknek/áruknak fordítható le. ${ }^{17}$ Végül de nem utolsó sorban érdemes megjegyezni, hogy a vadvilággal kapcsolatos cselekményeken belül kiemelendő egy külön kategória, a ,forest crime”. Az erdőkkel, erdészettel kapcsolatos büntetendő cselekmények körébe olyan tevékenységek tartoznak, amelyek az erdők jogellenes kiaknázásával, a védett fa- és egyéb erdészeti fajok jogellenes kivágásával és azok kereskedelmével valósulnak meg. A ,forest crime” elnevezést szintén elfogadott módon lehet erdészeti büncselekményeknek fordítani, így a dolgozatban is ezt az elnevezés jelenik meg.

Az egyes, értekezés szempontjából szignifikáns angol nyelvű elnevezések általam használt és elfogadott fordítása a következő táblázatban kerül összefoglalásra. Az egyes fogalmi elnevezések többes számban történő alkalmazását indokolja, hogy azok gyüjtőfogalomnak tekinthetők és több módon, több elkövetési magatartással is megvalósíthatók.

${ }^{17}$ A vadvilági termékekről és azok felhasználásáról bővebben: In: H. ROTH, HARALD - MERZ, GÜNTER (Szerk.): Wildlife Resources: A Global Account of Economic Use. Springer-Verlag, Berlin Heidelberg, 1997. 403. p. 
1. táblázat Terminológia ${ }^{18}$

\begin{tabular}{|l|l|}
\hline \multicolumn{1}{|c|}{ Angol nyelvü elnevezés } & \multicolumn{1}{c|}{ Magyar nyelvü elnevezés } \\
\hline environmental crime & $\begin{array}{l}\text { környezet elleni büncselekmények/kör- } \\
\text { nyezeti büncselekmények }\end{array}$ \\
\hline wildlife crime & $\begin{array}{l}\text { vadvilággal kapcsolatos büntetendö cse- } \\
\text { lekmények/vadvilággal kapcsolatos bün- } \\
\text { cselekmények }\end{array}$ \\
\hline wildlife cybercrime & $\begin{array}{l}\text { vadvilággal kapcsolatos kiberbüncselek- } \\
\text { mény }\end{array}$ \\
\hline wildlife trade & $\begin{array}{l}\text { vadvilági kereskedelem/vadon élö fajok } \\
\text { kereskedelme }\end{array}$ \\
\hline wildlife market & vadvilági termékek piaca \\
\hline wildlife product(s) & vadvilági termék(ek)/áru(k) \\
\hline forest cime & erdészeti büncselekmények \\
\hline
\end{tabular}

18 1. táblázat, szerző saját szerkesztése. 


\section{A vadvilággal kapcsolatos büntetendő cselekmények jelen- tősége}

„A jó lényege az élet fenntartása és tisztelete, a rossz lényege az élet elpusztitása és kárositása. Minden élölény élni akar, s minden élni akarással rendelkezö élölény szent, egymással kapcsolatban álló és egyenlö értékü.

Ezért etikai parancs a számunka, hogy tiszteljünk és segitsünk minden életformát." 19

Nem vitás, hogy a vadvilággal kapcsolatos és erdészeti büncselekmények egyes szervezett bünözői csoportok fö bevételi forrásává váltak. A vadvilági termékekkel történő kereskedelem ugyanannak az éremnek a másik oldala. A vadvilági termékekkel folytatott illegális kereskedelem növekedése Ázsiában és Európában, valamint az Amerikai Egyesült Államokban jellemző, amely föként az elefántcsontra, orrszarvúszarvra és tigristermékekre való keresleti igénnyel magyarázható. A vadvilági termékekkel folytatott illegális kereskedelem jelenleg az ötödik - egyes források szerint már harmadik - legjövedelmezőbb tiltott kereskedelmi tevékenységnek minősül, éves szinten mintegy 10 milliárd USD forgalommal. Sikere abban rejlik, hogy „,kis kockázat-nagy haszon” tevékenységnek minősül, hiszen az illegális kereskedelmet folytató csoportok kihasználják a rendszer repedéseit. ${ }^{20} \mathrm{~A}$ környezet elleni büncselekmények megvalósítását elősegítő tényezőket részletesen ismertetem az értekezés későbbi részében. Elöljáróban annyit meg lehet jegyezni, hogy a problémák megjelennek mind a szabályozás, mind a végrehajtás és az igazságszolgáltatás szintjein, ezzel segítve a bünelkövetőket. Napjainkban a világpiacon az orrszarvúszarvnak magasabb az értéke, mint az aranynak: a szarvakat kilogrammonként 25.000 - 40.000 USD áron hozzák forgalomba a feketepiacon. Az ok elsősorban az, hogy az ázsiai országokban továbbra is hisznek az egyes, állatokból készült termékek gyógyító hatásában. A közelmúltban újra terjednek a tradicionális medicina rákgyógyító hatásáról szóló hírek, amelyre egy vietnámi politikus saját gyógyulásáról tett beszámolója is ráerősített. Természetesen a vadvilági termékek mindig is vonzók voltak bizonyos

\footnotetext{
19 Albert Schweitzer (1987-1965), elzászi német teológus, lelkész, filozófus, orgonaművész, tanár, orvos, Nobel-békedíjas (1952).

Idézet forrása: SCHWEITZER, ALBERT 1923. Civilization and Ethics. Trans.: J. Naish. A \& C Black, London 29. p.

${ }^{20}$ STOP Wildlife Crime https://www.worldwildlife.org/pages/stop-wildlife-crime (2019. 03. 24.).
} 
társadalmi réteg számára és a rang kifejezésének tekintik egy-egy elefántcsontból faragott szobor vagy elefántláb-asztalka beszerzését. ${ }^{21}$

2018 őszén röppen fel a hír, hogy Kína feloldja az 1993 óta tartó kereskedelmi tilalmat a tigriscsont és orrszarvúszarv tekintetében. Az új, elfogadásra váró szabályozás alapján kórházakban lehetne alkalmazni a fogságban tartott, ún. tigrisfarmokról származó egyedek csontjait és a nem vadvilágból származó orrszarvú-részeket. A hír világszerte ellenérzést váltott ki, mivel a kereskedelem legalizálása gátat szabna a fajmegőrzési erőfeszítéseknek és utat nyitna az orvvadászatnak, a vadon élő egyedek vadászatának. ${ }^{22} \mathrm{~A}$ tiltakozások hatására 2018 novemberében Kína elhalasztotta a szabályozás elfogadását. ${ }^{23} \mathrm{~A}$ kínai kereskedelmi szabályok módosítására vonatkozó aggodalmak is rámutatnak egy, a vadon élő és vadvilágból származó egyedekkel és termékekkel kapcsolatos dilemmára. Példák igazolják - később az értekezésben is megjelenik a legeklatánsabb, az afrikai elefántok esete - hogy az engedélyezett kereskedelem utat nyit az orrvadászatnak és gyengíti a fajmegőrzési törekvéseket. Ugyanakkor a szabályozás tekintetében megjelenik az ellenvélemény is, amely szerint éppen a tilalom és korlátozás eszközei vezettek az orvvadászat elterjedéséhez és a kiterjedt illegális piacok kialakulásához. ${ }^{24}$ Álláspontom szerint a biodiverzitás megőrzésének eszközkészlete nem zárkózhat el a tilalmazástól és a szankcionálástól, azonban a már kereskedelmi forgalomban lévő és a szabályozás tárgyát képező termékekből származó hasznot fel lehetne használni a fajmegőrzési törekvések támogatására. A jogi keretek megőrzése érdekében azonban a részletes közgazdaságtani elemzéstől eltekintek.

A fajok gazdasági célú kiaknázása mindig is fontos része volt egyes közösségek fennmaradásának, hiszen sok esetben ez az egyetlen kereseti lehetőség. Különösen igaz ez egyes fejlődő államok kisebb közösségeire, akik a természeti környezet integráns részeként

\footnotetext{
${ }^{21}$ Az orrszarvú szarva az élet kulcsa? http://wwf.hu/archivum/2010ev/24/az-orrszarvu-szarva-az-elet-kulcsa (2019. 03. 24.).

${ }^{22}$ Az értekezés IV.3.2. fejezetében egy esettanulmányon keresztül kerül bemutatásra, milyen hatással lehet az orvvadászatra a CITES függelékekbe való besorolás és a legalizált kereskedelem.

${ }^{23}$ In a blow to wildlife, China lifts a ban on the use of tiger and rhino parts. 2018. október 29. https://www.worldwildlife.org/stories/in-a-blow-to-wildlife-china-lifts-a-ban-on-the-use-of-tiger-andrhino-parts (2018. 12. 15.).

${ }^{24}$ Egyes tanulmányok rámutatnak az I. Függelékbe való sorolás, a nemzeti szintű tilalmak és a jogellenes kereskedelem közötti összefüggéskere, vagyis a jogszerü és illegális kereskedelem között pont ellentétes kapcsolat van. In: SANTOS, ANNA - SATChabut, ThitiKAn - Vigo Trauco, GabriEla: Do Wildlife Tade Bans Enhance or Undermine Conservation Efforts? Applies Biodiversity Perspective Series, 1(3) 1-15. p. 2011. Továbbá: KASTERINE, ALEXANDER: To ban or not to ban: Assessing the scope for legal wildlife trade. International Centre for Trade and Sustainable Development. 2014. május 13.

http://www.ictsd.org/bridges-news/biores/news/to-ban-or-not-to-ban-assessing-the-scope-for-legal-wildlife-trade (2019. 07. 23.).
} 
élnek, amely egyben biztosítja mindennapi létfeltételeiket is. Mindazonáltal az ilyen közösségek mai fogalmaink szerint a fenntarthatóság keretein belül használták és használják ki a természeti erőforrásokat. Az elmúlt néhány évtizedben, a fejlett államokban jelentkező kereslet hatására, a felelőtlen és túlzott vadászat, halászat, befogás és erdőirtás felgyorsította a fajok kihalását, mivel a regenerációra nem maradt lehetőség. A vadvilág jogellenes kizsákmányolásának súlyos gazdasági, társadalmi és környezeti hatásai vannak, aláássák a fenntartható fejlődés koncepcióját. Az ökoszisztéma különösen fontos szerepet játszik a fejlődő gazdaságokban, az állami bevételek támogatásán és a jövőbeli fejlesztési lehetőségek biztosításán keresztül. Az ökoszisztéma támogatja a turizmust is a nemzeti gazdaságok körülbelül 5-10 százalékában és más alapvető szerepet is nyújt: mint például az extrém időjárási jelenségek - beleértve az áradásokat, szárazságokat, tiszta ivóvíz biztosítását - hatásainak kiküszöbölését. Az egészséges ökoszisztéma alapja az állam gazdasági fejlődésének és a jövőbeli biztos élelmiszer-ellátásnak. Mindeközben az ökoszisztémában rejlő fejlődési lehetőséget veszélyezteti az egyre inkább teret nyerő határon átnyúló szervezett bünözés, aláásva a fenntartható fejlesztési célok és a „,good governance" megvalósulását. A vonatkozó nemzetközi szervezetek becslései szerint a határon átnyúló szervezett környezeti bünözés értéke évente 70 és 213 milliárd USD között mozog. ${ }^{25}$ A jogellenes kereskedelem szociáletikai és gazdasági következményekkel jár; például a helyi közösségek alapvető erőforrásaira való hatásokkal és állami szinten a természeti tőke eltulajdonítását eredményezi. Így az illegális kereskedelem akadályt állít a fenntartható fejlődés elé. Számos negatív tényező állapítható meg, amelyekbe beletartoznak a gyenge környezeti kormányzás, a szabályozatlan kereskedelem, a szervezett bünözést elősegítő jogi szabályozási hiányosságok és pénzmosási gyakorlat. Az illegális vadvilági kereskedelem aláássa a kormányzati rendszereket és a jogszerü üzleteket. Az illegális kereskedelem a növény- és állatvilág széles skáláját érinti, több kontinensen. A szervezett bünözés mértéke, szofisztikált módja és globalizált volta sok állam felkészültségét és erőforrásait meghaladja. Emiatt a vadvilági bünözés elleni küzdelem differenciált fellépést és összefogást igényel az államok, bűnüldöző szervek és nemzetközi szervezetek részéről. Azonban a megerősített végrehajtási erőfeszítéseknek ki kell egészülniük a

${ }^{25}$ UNEP/EA.1/INF/19 (2014. május 21.) Illegal trade in wildlife: the environmental, social and economic consequences for sustainable development 1. p. 1-2. pontok. [Továbbiakban: UNEP/EA.1/INF/19]. 
társadalom felé irányuló figyelemfelhívással, valamint a társadalmi tudatosság fejlesztésével. ${ }^{26}$

Bár a fenntartható fejlődés fogalma már az 1980-as években bevonult a köztudatba, annak gyakorlati megvalósulása leginkább a Millenniumtól alkalmazott célokban érhető tetten. A fenntartható fejlődés „olyan fejlődés, amely biztositani tudja a jelen szükségleteinek kielégitését anélkül, hogy veszélyeztetné a jövő generációk lehetöségeit saját szükségleteik kielégitésére." ${ }^{27}$ Az ENSZ Millenniumi Deklarációjában ${ }^{28}$ megfogalmazott nyolc célkitűzés tizenöt éven keresztül szabott keretet a nemzetközi közösség és az államok fellépésének. Utóbbiak közül egy, a hetedik cél foglalkozott a környezeti fenntarthatóság kérdésével, többek között az erdöírtással és a biológiai sokféleség csökkenésével. Az MDGs-ek több tekintetben fejlesztésre szorultak, ezért kerültek megfogalmazásra az SDGs-ek, amelyek napjainkban is segítséget nyújtanak a legfontosabb társadalmi, gazdasági és környezeti fejlesztési programok kialakításához. ${ }^{29}$

A fenntartható fejlődési célok közül, amelyek a fejlödés kereteit biztosítják a 2015-től 2030-ig tartó időszakban, többet is fenyegetnek a vadvilággal kapcsolatos büncselekmények. Ide sorolható a hozzáférhető és megfizethető energia (7. célkitüzés), a felelős fogyasztás és termelés (12. cél), az óceánok és tengerek védelme (14. cél), a szárazföldi ökoszisztémák védelme (15. cél), de közvetetten az államok fejlődését is befolyásolja. Így akadályozzák az olyan gazdasági fejlődés megvalósulását, amelyek elősegítik a szegénység és éhínség felszámolását (1. és 2. célkitűzések), a fenntartható városok és gazdaságok létrehozását (11. cél), a tisztességes munkához való hozzáférhetőséget és a gazdasági növekedés elérést (8. cél). ${ }^{30}$ Összességében megállapítható, hogy a környezeti bűncselekmények és a vadvilággal kapcsolatos büntetendő cselekmények akadályozzák a fenntartható fejlesztési célok megvalósulását, és azoknak a pénzügyi eszközöknek a

\footnotetext{
${ }^{26} \mathrm{UNEP} / \mathrm{EA} .1 / \mathrm{INF} / 19$ 7-8. p. 36. bekezdés (a)-(g) pontok.

${ }^{27}$ Brundtland Bizottság Közös Jövőnk c. jelentés, 1987. 41. p.

„Sustainable development is development that meets the needs of the present without compromising the ability of future generations to meet their own needs."

Online elérhetö: Report of the World Commission on Environment and Development: Our Common Future. https://sustainabledevelopment.un.org/content/documents/5987our-common-future.pdf.

${ }^{28}$ United Nations Millennium Declaration, 2000 szeptembere.

${ }^{29}$ A 2015-ben elkészült végső jelentésben is megmutatkozik, hogy a biodiverzitás megőrzése érdekében elfogadott 7.B. alcélkitüzés tekintetében bár történt elörelépés, de meg kell erősíteni a fajok kihalásának megakadályozása érdekében tett lépéseket.

In: The Millennium Development Goals Report, 2015. 57. p.

https://www.undp.org/content/dam/undp/library/MDG/english/UNDP_MDG_Report_2015.pdf (2019. 07. 23.).

${ }^{30}$ Sustainable Development Goals https://sustainabledevelopment.un.org/sdgs (2018. 12. 29.).
} 
hatékony befektetését, amelyeket az nemzetközi közösség a célok megvalósítása érdekében bocsát rendelkezésre. Mindez elsősorban a gazdaságilag kevésbé fejlett vagy fejlődő országokat érinti.

Felismerve, hogy a vadvilágot érintő büncselekmények jelentős negatív hatással vannak a biológiai sokféleségre, a 15., „biodiverzitás” célkitűzés két alfejzete is kifejezett előírásokat fogalmaz meg. A 15.7. cél felhívja az államokat, hogy tegyenek sürgős lépéseket a vadon élő védett állat- és növényfajok orvvadászata és kereskedelme felszámolása érdekében, és mind a kereslet, mind pedig a kínálat oldaláról igyekezzenek gátat szabni a vadvilági termékek illegális piacának. A 15.C. keretében pedig megerösített globális együttműködésre hívják fel a tagállamokat a védett fajok orvvadászata és illegális kereskedelme felszámolásának érdekében, ideértve a helyi közöségek fenntartható fejlődésének elősegítését is. ${ }^{31}$

A vadvilággal kapcsolatos büncselekmények biodiverzitásra vonatkozó negatív hatására számos esetet lehetne hozni, mind a növény- mind pedig az állatvilágból. Mivel jelen értekezésnek nem célja az összes érintett faj bemutatása, egy példán keresztül szemléltetem, hogy a kínálat növekedése milyen hatással lehet egy-egy faj és ezen keresztül az ökoszisztéma fennmaradására.

A vadvilági kereskedelem jellemzője, hogy bár számos faj „áldozattá” válik, azonban az érdeklődés gyakran a kihalás szélére sodort egyes fajokat. A tobzoska (Manis penta-dactyla dalmanni) jelenleg a legkeresettebb emlősállat a világon, mivel keratinból álló pikkelyeit az ázsiai tradicionális medicina gyógyító erővel ruházza fel. Másodsorban húsáért is vadásszák, azonban elsősorban pikkelyeiért, amelyet szárítanak, majd több módon sütnek, föznek és felhasználnak. Az elmúlt évtizedben körülbelül 1 millió példányt fogtak be a vadonból. Mivel veszély esetén a hangyász összegömbölyödik és védekező állást vesz fel, könnyü prédája az illegális vadászatnak és befogásnak. ${ }^{32} 2018$ nyarán 7 tonna (15 ezer egyed) tobzoska pikkelyt foglaltak le Hong Kongban, amelynek célállomása Nigéria lett volna. ${ }^{33} \mathrm{~A}$ tobzoska kihalásának fenyegető közelsége miatt a kereskedelmi tevékenység minden formája tilalmazott a CITES alapján. ${ }^{34} 2018$ decemberében csaknem három tonna Afrikából érkezett és elkobzott tobzoska pikkelyt égettek el Malajziában, 9

\footnotetext{
${ }^{31}$ 15. Life on land https://www.un.org/sustainabledevelopment/biodiversity/ (2019. 01. 02.).

32 Pangolins https://www.pangolinsg.org/pangolins/ (2019. 03. 02.).

33 Mandy Zuo: '15,000 pangolins slaughtered' for 7 tonnes of scales seized in China. https://www.scmp.com/news/china/society/article/2166083/15000-pangolins-slaughtered-7-tonnes-scalesseized-china (2019. 03. 02.).

${ }^{34}$ Johannesburgban, 2016 szeptemberében döntöttek így a részes felek.
} 
millió USD értékben. A $2800 \mathrm{~kg}$ pikkely megszerzéséhez 3 ezer állatot kellett megölni. Az elkobzásra Port Klang-ben került sor 2017 májusa és szeptembere között. A szállítmányok Kamerunból és Ghánából érkeztek, amelyeket törvényszéki módszerekkel azonosítottak, hogy afrikai fajok voltak. ${ }^{35}$ Mivel az Ázsiában honos tobzoska fajok az intenzív vadászatnak köszönhetően a kihalás szélére sodródtak, a vadászat elsősorban az afrikai kontinensre helyeződött át. 2016 nyarán 11 tonna pikkelyt foglaltak le Hong Kongban, amelyek csak két afrikai szállítmánnyal érkeztek. ${ }^{36}$ Utóbbi eset kapcsán is tetten érhető, hogy az egyes fajok iránti kereslet hogyan vezet el azok szinte mértéket nem ismerő pusztításához. Azonban a fajmegőrzési kísérleteket tovább nehezíti az olyan új típusú piacok megjelenése, amelyek egyfajta „fekete lyukként” még nem képezik a szabályozás tárgyát vagy annak újszerüsége miatt még nem sikerült azokat hatékony kontroll alá helyezni. A téma jelentősége miatt a továbbiakban röviden kitérek az internet és a globalizáció hatásaira.

A fajmegőrzési kísérleteket és terveket sok esetben aláássák a globalizáció és az új piacipiaci lehetőségek eredményeként létrejövő változások. A technológiai fejlesztések hatására a kereskedelmi kapcsolatok is átalakultak, a piac struktúrája is megváltozott. Ennek eredményeként a jognak és így a nemzetközi környezetvédelemnek is folyamatosan új kihívásokkal kell szembenéznie és azokhoz adaptálódni. Az online kereskedelmi platformok az egyik legfontosabb olyan terület, ahol a XXI. század elejétől fogva jelentős, addig nem ismert kockázat jelent meg.

Bill Gates mondta, hogy „az internet a holnap globális falujának föterévé válik.” ${ }^{37} \mathrm{Az}$ idézet a vadvilági kereskedelemhez képszerüen is illik, hiszen a vadvilági termékeket mind a mai napig sokszor hagyományos piactereken, ún. vadvilági piacokon árulják. Különösen igaz ez a megállapítás a beszerzési országokban, amelyek gyakran fejlődő államok. Azonban ahogyan az internet megváltoztatta az életünket az elmúlt alig egy-két évtizedben, úgy alakította át és feszítette szét a hagyományos kereskedelem határait is.

\footnotetext{
${ }^{35}$ Malaysia torches 2.8 tonnes of African pangolin scales. 2018. december 06. https://phys.org/news/201812-malaysia-torches-tonnes-african-pangolin.html (2019. 03. 02.).

${ }^{36}$ Damian Carrington: Pangolins thrown a lifeline at global wildlife summit with total trade ban. 2016. szeptember 28.

https://www.theguardian.com/environment/2016/sep/28/pangolins-thrown-a-lifeline-at-global-wildlifesummit-with-total-trade-ban (2019. 03. 02.).

${ }^{37}$ Idézet forrása: GATES, BILL: Business @ the Speed of Thought: Succeeding in the Digital Economy. Grand Central Publishing. NY, 1999. 131.p.

„The Internet is becoming the town square for the global village of tomorrow."
} 
Az elmúlt száz évben, de különösen az utóbbi néhány évben a kereskedelem teljes mértékben átalakult, köszönhetően az online elérhető szolgáltatásoknak. ${ }^{38}$

Bár a változások összességében pozitívak, az online kereskedelem nem pusztán a legális kereskedelem határait bővítette, hanem teret engedett a fekete piacnak is. Az ún. „darkweb” a prostitúció, fegyver- és drogkereskedelem, pénzmosás és egyéb illegális ügyletek helyszíne, amely néhány perces keresés után az otthonokból is elérhető. A darkweb alapvetően olyan platformokat foglal magába, amelyek szándékosan rejtettek és felületes kereséssel nem érhetők el. Azonban számos olyan segédlet áll rendelkezésre, amely akár tíz lépésben elmagyarázza, hogyan lehet az említett oldalakhoz hozzáférni. Továbbá, könnyen elérhetőek azon módszerek, amelyekkel privát, a felhasználók kilétét és lakóhelyét elrejtve, a kommunikáció tartalmát bizalmasan kezelve folytathatók ügyletek. ${ }^{39}$ Érdekes, hogy miközben széles körben elfogadott nézet, hogy az online kereskedelem a vadvilággal kapcsolatos büncselekmények egyik legújabb és legfenyegetőbb formája, egyes kutatások csupán minimális bizonyítékot találtak a darkweben folytatott tevékenységre, azt is elsősorban az elefántcsonttal kapcsolatosan. ${ }^{40}$ Így egyes kutatások arra a megállításra jutottak, hogy a vadvilági kereskedelem - különös tekintettel az internet rejtett oldalaira - csupán járulékos jellegü. Azonban az olyan „social media” oldalak, mint a Facebook, az Instagram, a Twitter és YouTube is helyszínként szolgálhatnak az vadvilági termékek hirdetéséhez, amely további vizsgálódást igényel. ${ }^{41}$

Véleményem szerint az, hogy egyes kutatások csupán kevés példát találtak a darkweben történő vadvilági kereskedelemre, nem bizonyítja a jelenség csekély mértékét. Az olyan kiterjedt megfigyelések, akciók, amelyeket nemzetközi szintű és jelentős erőforrásokkal rendelkező szervezetek végeztek, az online vadvilági kereskedelem széles körű elterjedtségéről adtak tanúbizonyságot.

A darkweben azért is található meg csupán járulékos jelleggel a vadvilági kereskedelem, mivel az a legtöbbször nem rejtetten, hanem könnyen elérhető, publikus felületekről történik. Az IFAW által vezetett kutatás eredménye alapján, ahol 106 online piacteret és 3

\footnotetext{
${ }^{38}$ Bövebben: Bennett O’Brien: Four major ways international trade has changed over the past one hundred years. 2015. 01. 13.

http://www.tradeready.ca/2015/trade-takeaways/four-ways-international-trade-changed-one-hundred-years/ (2019. 01. 27.).

39 Bővebben: REED, MichAEL - SYVERSON, PAUL - GOLDSCHLAG, DAVID: Anonymus Connections and Onion Routing. 1997. IEEE Symposium on Security and Privacy 1-11. p. http://cs.unc.edu/ fabian/course_papers/syverson97anonymous.pdf (2019. 01. 28.).

40 HARrison, JosePH R.- RoBerTs, DAVID L.- HERnANDEZ-CASTRO JUlio C.: Assessing the extent and nature of wildlife trade on the darkweb. Conservation Biology Vol. 30. 2016. augusztus 900-904. p.

${ }^{41}$ RoBERTS, DAVID L.- HERNANDEZ-CASTRO Julio C: Bycatch and illegal wildlife trade on the dark web. Oryx, The journal of Flora and Fauna International. 2017. 393-394. p.
} 
„social media” felületet vizsgáltak meg, összesen 5381 hirdetést vagy posztot találtak, amelyek 80 százaléka élő egyedekre, 20 százaléka pedig részekre vagy termékekre vonatkozott. Csaknem 12 ezer védett példányt árultak, majdnem 4 millió USD értékben, amelyek 11 százaléka elefántcsont vagy abból készült termék volt és az esetek körülbelül felében hüllőkkel kapcsolatos hirdetésekre leltek. ${ }^{42}$

A vadvilággal kapcsolatos büntetendő cselekmények köre, különösen az illegális vadvilági kereskedelem jelentős mértékben kihasználja a modern kor kínálta új lehetőségeket, amelyek megkönnyítik a jogellenesen megszerzett termékek és egyedek adásvételét. Így az online kereskedelem egyre nagyobb kihívás elé állítja a természetvédelmi hatóságokat. Az állatok jólétével foglalkozó nemzetközi alap kutatása szerint Európa területén virágzik a veszélyeztetett fajok online kereskedelme. Az alap kutatói hat héten át követték figyelemmel Oroszország, az Egyesült Királyság, Németország és Franciaország száz online piacterét. Összesen több mint ötezer vonatkozó hirdetést találtak, csaknem 12 ezer eladásra kínált tételt, mintegy 4 millió USD értékben. Utóbbi kizárólag azon példányokra vonatkozó mutatószám, amelyek kereskedelme korlátozás alá esik a CITES alapján. A hirdetések csaknem ötöde elefántcsontra vonatkozott. Amíg az elefántcsont iránti kereslet az Egyesült Királyságban lassan csökkenésnek indult, Németországban folyamatosan növekvő ütemet mutat. Az Egyesült Királyság még szigorúbb szabályozást készül elfogadni az elefántcsontra vonatkozóan. Az Európai Unió állandó nyomás alatt van az elefántcsontpiac teljes lezárásáért. A kedvencként tartott egyedek közül még mindig a hüllők a legnépszerübbek, a vonatkozó hirdetések csaknem negyven százalékát adva. A nagymacskák házi kedvencként való tartása Oroszországban státuszszimbólumnak minősül, így ott leopárdokat, jaguárokat és gepárdokat kínálnak eladásra. ${ }^{43}$

A nem kormányzati szektor egyre nagyobb szereppel bír a természet- és állatvédelmi területen, beleértve a vadvilággal kapcsolatos büntetendő cselekményeket. Az olyan nemzetközi NGO-k, mint a WWF, kiemelt ügyként tekintenek a fajok fennmaradását jelentős mértékben veszélyeztető jelenségekre. Azonban egyes szervezetek a nemzetközi szektorral és a CITES Titkársággal való együttmüködésbe is bekapcsolódtak. Már többször

\footnotetext{
${ }^{42}$ IFAW: Disrupt: Wildlife Cybercrime. Uncovering the scale of online wildlife trade. 13. p. https://www.ifaw.org/sites/default/files/IFAW\%20-\%20Disrupt\%20Wildlife\%20Cybercrime\%20\%20English.pdf (2019. 01. 28.).

${ }^{43}$ CARRINGTON, DAMIAN: Illegal online sales of endangered wildlife rife in Europe. The Guardian, 2018. május 23. https://www.theguardian.com/environment/2018/may/23/illegal-online-sales-of-endangered-wildlife-rifein-europe (2019. 03. 29.).
} 
történt utalás arra, hogy a vadvilággal kapcsolatos büntetendő cselekmények köre összetett jelenség, így az arra vonatkozó programok, akciótervek kidolgozása is komplex szemléletmódot kell, hogy tükrözzenek. Az NGO szektor olyan szaktudást és látásmódot biztosít, amely nem biztos, hogy a kormányközi szervezetekben vagy egyéb államközi együttmüködésekben rendelkezésre áll.

Az egyik legfontosabb NGO a TRAFFIC, amely a vadvilági kereskedelem kérdéskörét a biodiverzitás megőrzése és a fenntartható fejlődés szemszögéből közelíti meg. ${ }^{44}$ A TRAFFIC öt kontinensen és tizenöt államban van jelen, több mint száz munkatársa között akadémikusok, biológusok, természetvédők, kutatók, befektetők és kommunikációs szakemberek is vannak. 2010-es megalakulása óta mintegy nyolcvan riportban ${ }^{45}$ foglalkoztak a vadvilági kereskedelemmel. ${ }^{46}$ A CITES végrehajtása és a tanácsadás a TRAFFIC munkájának egyik prioritása, továbbá minden konferenciához és az elfogadott döntésekhez javaslatokat és ajánlásokat fogalmaznak meg. A kereskedelmi információs és szakértelmi rendszeren keresztül jelentős támogatást nyújtanak a Washingtoni Egyezménynek. ${ }^{47} \mathrm{~A}$ TRAFFIC és a WWF között is együttmüködés jött létre (Wildlife Crime Initiative) 2014ben, amelynek négy eleme az orvvadászat, a kereskedelem megállítása, a kereslet felszámolása és a megfelelő nemzetközi politikai stratégiák kialakítása. ${ }^{48}$

Az illegális kereskedelem témakörében számos regionális és globális konferenciát, tanácskozást rendeztek az elmúlt évtizedben. Ezek egy része különösen kiemeli a Konzorciummal (ICCWC) való együttmüködést is, a fajok megőrzése érdekében. A regionális találkozók közül kiemelésre érdemes az Elefántcsontkereskedelemről szóló afrikai elefánt csúcstalálkozó, amelyet 2013 decemberében, Botswanában tartottak. A konferencia záródokumentumaként elfogadott „Sürgető Lépések” deklarációban említésre kerülnek a szervezett bünözés és a korrupció, amelyek támogatják és lehetővé teszik az orvvadászatot és az elefántcsontkereskedelmet. Az intézkedések között hangsúlyozzák az együttmüködés megerösítését a származási, tranzit- és célországok között, illetve a Konzorcium támogatásának szükségességét. ${ }^{49}$ Az Afrikai Fejlesztési Bank éves találkozóján, 2013

\footnotetext{
${ }^{44}$ TRAFFIC, Wildlife Trade Specialists https://www.traffic.org/ (2019. 03. 09.).

${ }^{45}$ TRAFFIC Publications https://www.traffic.org/publications/ (2019. 03. 09.).

${ }^{46}$ TRAFFIC Our Organisation https://www.traffic.org/about-us/our-organisation/ (2019. 03. 09.).

${ }^{47}$ TRAFFIC Working with CITES https://www.traffic.org/about-us/working-with-cites/ (2019. 03. 09.).

48 TRAFFIC Wildlife Crime Initiative https://www.traffic.org/what-we-do/projects-and-approaches/wildlife-crime/wildlife-crime-initiative/ (2019. 03. 09.).

${ }^{49}$ African Elephant Summit, Gaborone, Botswana, 2013. december 2-4. Urgent Measures, 2013. december 3. 1-5. p.

Online elérhető: https://cmsdata.iucn.org/downloads/african_elephant_summit_final_urgent_measures_3_dec_2013.pdf
} 
májusában egy tíz pontból álló akciótervben állapodtak meg a résztvevők, az illegális vadvilági kereskedelem elleni küzdelemről. Az elfogadott akciók négy csoportba sorolhatók: együttmüködés kiépítése (UNODC, ICCWC), a jogszabályok hatékony végrehajtása és kikényszerítése, a vadvilági büncselekmények büntetése és a vadvilági termékek iránti kereslet csökkentése. ${ }^{50}$

Globális szinten is számos konferenciát, találkozót rendeznek a vadvilágot károsító cselekmények kapcsán. 2014 februárjában tartották az Illegális vadvilági kereskedelemről szóló Londoni Konferenciát, ahol mind államok széles köre (pl. USA, Kína, afrikai államok, Japán, dél- és közép-amerikai, valamint ázsiai országok), mind regionális gazdasági integrációk (EU) képviseltették magukat. A Londoni Deklaráció azontúl, hogy leszögezi a jogellenes kereskedelem mértékét és a sürgető intézkedések szükségességét, meghatároz huszonöt, öt különböző témakörbe sorolt akciót is, amelyeket az államok igyekeznek megvalósítani. ${ }^{51}$ Hasonló résztvevői körrel került megrendezésre Az illegális vadvilági kereskedelemröl szóló Kasani Konferencia, 2015 márciusában, ahol megerősítették a Londoni Deklarációban foglalat vállalásokat. Továbbá, hangsúlyozták a Konzorciummal való szoros együttmüködés és a regionális, vadvilági területen müködő végrehajtó csoportok létrehozásának szükségességét. ${ }^{52} 2015$ áprilisában Brazzavilleben találkoztak a felek, az Afrikai vadon élő növény- és állatvilág illegális kizsákmányolása és a jogellenes vadvilági kereskedelem konferencián. ${ }^{53}$

Összességében tehát megállapítható, hogy a vadvilággal kapcsolatos büntetendő cselekmények köre napjaink egyik legnagyobb környezeti kihívása, amely aláássa a fenntartható fejlődés koncepcióját, a fejlődő országok felemelkedését, továbbá elvezet a biodiverzitás csökkenéséhez és a fajok felgyorsított ütemü kihalásához. Mint jelenség, a

\footnotetext{
${ }^{50}$ African Development Bank (AfDB) Annual Meeting, 2013 májusa, The Marrakech Declaration. A 10point Action Plan to Combat Illicit Wildlife Trafficking 1-3. p.

Online elérhető: https://www.afdb.org/fileadmin/uploads/afdb/Documents/Generic-Documents/The\%20Marrakech\%20Declaration\%20-\%20A\%2010-Point\%20Action\%20Plan\%20to\%20Combat\%20Illicit\%20Wildlife\%20Trafficking.pdf.

${ }^{51}$ London Conference on the Illegal Wildlife Trade, 2014. február 12-13. Declaration, 1-11. p. Online elérhetö: https://assets.publishing.service.gov.uk/government/uploads/system/uploads/attachment_data/file/281289/london-wildlife-conference-declaration-140213.pdf.

52 Kasane Conference on The Illegal Wildlife Trade, 2015. március 25. Statement, 1-6. p.

Online elérhető: https://assets.publishing.service.gov.uk/government/uploads/system/uploads/attachment_data/file/417231/kasane-statement-150325.pdf.

${ }^{53}$ International Conference on Illegal Explotation and Illicit Trade in Wild Flora and Fauna in Africa, 2015. április 27-30. Brazzaville. A konferencián elfogadott záródokumentum megerősíti a korábbi deklarációkban foglaltakat és kiemeli az ICCWC által kidolgozott, a vadvilági bünözés elleni küzdelem érdekében kidolgozott eszköztár gyakorlati megvalósításának fontosságát.

Online elérhető: http://www.greatervirunga.org/IMG/pdf/brazza_declaration_final_en.pdf.
} 
vadvilágból származó egyedekkel és termékekkel történő kereskedelem mindig is fontos szegmense volt egyes államok, régiók gazdasági kapcsolatainak. Akár a saját közösségek fennmaradásának biztosításán, akár kereskedelmi tevékenység révén. A napjainkra eszkalálódott probléma leginkább a kereslet olyan szintü növekedésével magyarázható, amely már meghaladja a kínálati oldal teljesítőképességét. A következő fejezetekben feltárásra kerül a vadvilággal kapcsolatos büntetendő cselekmények és a szervezett bűnözés, a korrupció közötti kapcsolat, az államokra vonatkozó destabilizáló hatás.

Az értekezés szempontjából az elemzés fő kérdése az, hogyan interpretálható a jog nyelvén a vadvilággal kapcsolatos büncselekmények köre, azok milyen nemzetközi közjogi kérdéseket vetnek fel. Bár az értekezés fókuszpontjában a vadon élő fajokkal történő kereskedelem áll, fogalmi szinten kitekintés történik majd a többi, vadvilággal kapcsolatos büntetendő cselekményt megvalósító tevékenységre is. 


\title{
III. A vadvilággal kapesolatos büntetendő cselekmények fo- galmi kérdései
}

\begin{abstract}
„A vadvilággal és erdészettel kapcsolatos büncselekmények olyan megoldást követelnek, amelyek nemzetközi szinten megvalósuló együttmüködés keretében kivitelezett közös müveleteken, hírszerzési információk megosztásán, valamint erös és összeegyeztethetö nemzeti szabályozáson alapulnak. Ez a mi közös bolygónk; a vadvilággal és erdészettel kapcsolatos büncselekmények közös felelösségünk. ${ }^{\text {"54 }}$
\end{abstract}

A környezet, mint elkövetési tárgy és a környezetromboló magatartások egyre nagyobb jelentőségre tesznek szert mind individuális büntetőjogi felelősség, mind az államfelelősség tekintetében. Ahogyan az értekezés későbbi fejezeteiben még kitekintés jelleggel részletezem, a nemzeti és nemzetközi szinteken is hangsúlyossá vált a vonatkozó cselekmények üldözése és megfelelő jogkövetkezmények alkalmazása. A vadvilággal kapcsolatos büntetendő cselekmények köre mint jelenség, vitathatatlanul a túlzott fajkihalás egyik elsődleges oka, amely a nemzetközi közösség, az államok és nemzetközi szervezetek figyelmét is felkeltette. A nemzetközi és uniós jogi vetületeteket vizsgálva azonban több kérdés is vizsgálat tárgyát kell, hogy képezze.

Elsősorban annak eldöntése, hogy az adott jelenség kezelhetö-e egyáltalán a jogi fogalomként vagy csupán egy meghatározott probléma körülírására szolgál a nemzetközi szervezetek interpretációjában? Továbbá, ha egységes fogalom nem került eddig meghatározásra, az pótolható-e, vagy csak az egyes fogalmi elemek azonosíthatók? Hogyan formálódik a környezeti büncselekmények köre és ez elvezethet-e egy újabb nemzetközi büncselekmény kialakulásához? Továbbá, milyen eszközöket biztosít a transznacionális büncselekményekre alkotott nemzetközi jogi szabályozás a vadvilággal kapcsolatos büncselekmények területén?

\footnotetext{
${ }^{54}$ Yury Fedotov (Igazgató, UNODC), az ENSZ Bünmegelőzési és Büntető Igazságszolgáltatási Bizottságának 22. bécsi ülése, 2013.

Idézet forrása: https://www.unodc.org/unodc/en/wildlife-and-forest-crime/index.html (2019. 07. 23.).
} 


\section{III.1. A környezet elleni büncselekmények}

A vadvilággal kapcsolatos büntetendő cselekmények rendszertani szempontból a környezeti büncselekmények közé sorolhatók. Az angol terminológiában „environmental crime” elnevezésű gyüjtőfogalomnak - ahogyan a vadvilágot érintő cselekmények esetében is megállapítható - nincsen egységesen elfogadott definíciója. Általában véve elmondható, hogy a környezeti büncselekmény gyüjtöfogalom, amely alatt minden, a környezeti erőforrások kiaknázásából, kárositásából, kereskedelméböl vagy ellopásából eredö, egyéni vagy csoport számára történö haszonszerzés érdekében történö, környezetet kárositó jogellenes tevékenységet érteni kell. Az egyes, környezeti büncselekményekkel foglalkozó nemzetközi szervezetek interpretációjában is azok az elkövetési formák és a cselekmények következtében létrejövő eredmények kerülnek meghatározásra, amelyek általában jellemzik a környezet elleni büncselekményeket. ${ }^{55}$ Így például Európai Rendőrségi Hivatal a környezeti büncselekmények közé sorol minden olyan tevékenységet, amelyek a környezetjogi szabályozásba ütköznek és jelentős kárt okoznak vagy kockázatot hordoznak a környezetre és/vagy az emberi egészségre. Így utóbbi tevékenységek közé sorolható a védett, vadon élő állat- és növényfajok elpusztítása, károsítása, birtoklása vagy kereskedelme, ha az a jogszabályok megsértésével történik. ${ }^{56} \mathrm{~A}$ környezeti büncselekmények fogalma nem újkeletü, azonban jelentős bizonytalanságot hordoz magában, hiszen általában véve olyan cselekményekhez kötődik, amelyek egyébként jogszerüek és engedélyezettek, ha a jogszabályoknak megfelelően kivitelezik őket. Ráadásul, a környezeti károkozás - engedélyezett keretek között - jogszerünek tekinthető, gondolva egy, az előírásoknak megfelelő szénerőmü müködésére. A környezeti büncselekmények esetében a jogellenesség általában a súlyos károkozás eredménye. Utóbbiakra tekintettel kezd elterjedni a ,zöld kriminológia” irányzata, amely a környezeti büncselekmények hátterét összetett módon és környezeti szemléletben vizsgálja. ${ }^{57}$

Véleményem szerint a környezeti károkozásra a társadalom mindig is egyfajta elfogadó szemléletben tekintett. Hiszen az emberi, föként a mai értelemben vett élhető környezet kialakításával járó legalapvetőbb tevékenységek mind együtt járnak legalábbis, a

\footnotetext{
55 Az értekezésben kiemelésre kerülnek az ENSZ Közgyülés és Biztonsági Tanács, a UNEP, illetve a UNODC által elfogadott legfontosabb határozatok, valamint az NGO szektor, különös tekintettel a TRAFFIC-re.

56 Environmental Crime https://www.europol.europa.eu/crime-areas-and-trends/crime-areas/environmental-crime (2019. 07. 24.).

${ }^{57}$ WHITE, ROB - HECKENBERG, DIANA: Green Criminology: An Introduction to the Study of Environmental Harm. Routledge, NY, USA, 2014. 9-24. p.
} 
természetes környezet megváltoztatásával. Nem véletlen, hogy a környezet fogalmába és védelmébe beleértendő minden, az ember által alkotott elem is, mint például a müemlékek védelme. A kérdés az, hol húzódik az a morális határ, amely már meg kell, hogy jelenjen a jogi szabályozás szintjén is, magával vonva a büntetni rendelést is. A környezeti bűncselekmények fogalmában megmutatkozik, hogy egyes, az államok által a nemzeti büntetőjog keretében szabályozott tényállások között vannak hasonlóságok, legalábbis a védett jogi tárgy tekintetében. Azonban azok a kísérletek, amelyek a környezet büntetőjogi védelmének előírására vonatkoznak, nem érték még el a hozzájuk füzött reményeket és várakozásokat.

Összefoglalva, a környezeti büncselekmény kategóriája egy összetett és ellentmondásokkal tarkított fogalom. Gyakran gyüjtőfogalomként alkalmazzák a biodiverzitást, a vadvilágot, az állatokat, a természeti erőforrásokat, a veszélyes hulladékot, a tiltott anyagokat és a környezetminőséget érintő bűncselekmények tekintetében. Több esetben a környezeti büncselekmények sajátos osztályozását alkalmazzák, így „barna” (pl. szennyezés, levegőminőség), ,zöld” (pl. vadvilág kérdése és természetvédelmi erőfeszítések) és ,fehér" (tudományos tevékenységek és új technológiák, genetikailag módosított élőlények) cselekményeket különböztetnek meg. Az olyan szervezetek, amelyek környezeti területen is tevékenységet fejtenek ki, saját rendszert alakítanak ki, hogy mit értenek a környezet elleni büncselekmények alatt. Az EUROPOL interpretációjára már volt utalás korábban, míg az INTERPOL Környezeti Büncselekmény Programja három fő területre fókuszál: a biológiai sokféleségre, a természeti erőforrásokra és a környezetminőségre. ${ }^{58}$

Az értekezés szempontjából a vadon élő állat- és növényfajokat, illetve a biológiai sokféleséget érintő környezet elleni büncselekmények bírnak jelentőséggel. Azonban a rendszertani hely pontos meghatározása szempontjából, gyakorlati példákkal szemléltetve, röviden kiemelem a gyüjtőfogalomba tartozó cselekményeket.

A környezet elleni büncselekményeket valósitják meg a következö tényállások:

- jogellenes, be nem jelentett és szabályozatlan halászat;

- jogellenes bányászat és ásványokkal folytatott kereskedelem, beleértve a gyémántot;

- illegális fakivágás és erdőirtás;

- illegális kereskedelem vadvilági termékekkel és orvvadászat;

\footnotetext{
${ }^{58}$ GIBBS, CAROL - BORATTO, RACHEL: Environmental Crime. Oxford Research Encyclopedia, Criminology and Criminal Justice. 2017. március, 2.p. https://oxfordre.com/criminology/view/10.1093/acrefore/9780190264079.001.0001/acrefore9780190264079-e-269\#acrefore-9780190264079-e-269-bibItem-0014 (2019. 07. 24.).
} 
- veszélyes és toxikus anyagok illegális elhelyezése és azokkal való kereskedelem;

- ózonkárosító anyagokkal folytatott jogellenes kereskedelem. ${ }^{59}$

\section{Jogellenes, be nem jelentett és szabályozatlan halászat}

A nyílt tengerektől kezdődően a nemzeti joghatóság alá eső területekig előforduló jogellenes, be nem jelentett és szabályozatlan halászat ${ }^{60}$ az egyik legnagyobb veszélyt rejti a tengeri ökoszisztéma fennmaradására. A jogellenes halászati tevékenyéget folytatók kihasználják az adminisztrációs rendszerek gyengeségeit, a végrehajtás alacsony voltát, föként a fejlődő államokban. A környezet elleni büncselekmények ennek a formájánál is megmutatkoznak a korrupcióval és a szervezett bünözéssel való kapcsolat. ${ }^{61}$ A világ minden tengeri ökoszisztémájában megfigyelhető a halállomány csökkenése, amely magyarázható azzal, hogy a teljes tengeri fogás mintegy 35 százaléka jogellenes, nem bejelentett vagy szabályozatlan módon történik, éves szinten 23,5 milliárd USD veszteséget jelentve az érintett államoknak. ${ }^{62}$ Az Európai Unió a tisztességtelen gyakorlatot folytató piaci szereplők haszonszerzését lehetővé tevő kiskapuk megszüntetésére törekszik. Ezért külön rendelet fogadtak el és csak azon tengeri halászati termékek hozhatók be az Európai Unió területére, illetve exportálhatók, amiket a lobogó szerinti vagy az exportáló állam jogszerünek minősít. ${ }^{63}$

\section{Jogellenes bányászat és ásványokkal folytatott kereskedelem}

A bányászat mint tevékenység általában véve nem tilalmazott, hiszen a termelés egyik alapjának tekinthető. Azonban jelentős környezetformáló és szennyező hatásai miatt, szigorúan szabályozott és állami szinten müködtetett, vagy az által engedélyezett formában történik. Az ásványkincsek és erőforrások egy jelentős része a fejlődő országokban

\footnotetext{
${ }^{59}$ Nellemann, Christian (Szerk).: The Rise of Environmental Crime - A Growing Threat To Natural Resources Peace, Development And Security. A UNEP INTERPOL Rapid Response Assessment. UNEP, 2016. 31. p. [Továbbiakban: The Rise of Environmental Crime].

${ }^{60}$ IUU fishing: Illegal, Unreported and Unregulated fishing.

${ }^{61}$ Illegal, Unreported and Unregulated fishing (IUU fishing) http://www.fao.org/iuu-fishing/en/ (2019. 07. 25.).

${ }^{62}$ Global Ocean Commission, Drivers of Decline https://missionocean.me/drivers-of-decline/ (2019. 07. 25.).

${ }^{63}$ Európai Uniós szabályozás alapja: a Tanács 1005/2008/EK rendelete (2008. szeptember 29.) a jogellenes, nem bejelentett és szabályozatlan halászat megelőzésére, megakadályozására és felszámolására irányuló közösségi rendszer létrehozásáról (HL L 286., 2008.10.29., 1-32. p.) CELEX-szám: 32008R1005; valamint a Bizottság 1010/2009/EK rendelete (2009. október 22.) az 1005/2008/EK tanácsi rendelet alkalmazására vonatkozó részletes szabályok megállapításáról (HL L 280, 27.10.2009, p.5) CELEX-szám: 02009R1010-20130917.
} 
található meg, akik sokszor nem tudják kikényszeríteni a vonatkozó jogszabályok betartását, illetve nem folytatnak megfelelő ellenőrző tevékenységet. A jogellenes bányászat és ásványkereskedelem a környezet elleni büncselekmények egyik kiemelt formája, mivel összetett negatív társadalmi és gazdasági hatásokkal jár. Az illegális kitermelés a legtöbb földrészen megtalálható, az egyes ásványok és ércek világpiaci árának változása pedig jelentős hatással van az érintett tevékenységek mértékére.

A jogellenes aranybányászat veszélyezteti az Amazonas őserdőit és az őslakos népek földterületeit, egészségkárosító és környezetszennyező hatásai vannak. A hat Amazonas menti ország területén több mint 2300 illegális bányászati helyszínt azonosítottak, ahol elpusztították a természetes erdőségeket, szofisztikát infrastruktúrát alakítottak ki és arany-, gyémánt-, valamint koltán-bányászatot folytatnak, higannyal szennyezve a vizeket. A kitermelés olyan elzárt őslakos közösségek közelébe került, akik ki vannak téve az általuk nem ismert betegségeknek, járványoknak. A Brazília és Venezuela területén élő Yanomami őslakos csoport körében végeztek teszteket és az Aracaçá közösség tagjaitól vett hajminták 92\%-ban kimutatható volt a higany jelenléte. Brazíliában Jair Bolsonaro megválasztásával mind az illegális fakitermelés, mind pedig a bányászati tevékenység mértéke növekedni kezdett, utalva a vezetés és az egyes államokban folyó környezetromboló tevékenységek közötti összefüggésre. ${ }^{64}$ Azonban a jogellenes bányászati tevékenység az afrikai kontinensen is problémákat okoz, beleértve a Kongói Demokratikus Köztársaság területét, ahol föként az okostelefonokban is felhasznált kobaltbányászat jellemző. A jogellenes kitermelési helyszíneket felszámoló katonai erők által elkövetett emberi jogsérelmek rámutatnak az illegális bányászat további negatív hatásaira is. ${ }^{65}$ Végül, de nem utolsó sorban az illegális bányászat és kereskedelem legismertebb formája az ún. „véres gyémántok”. ${ }^{66}$ A gyémántbányászat e formája elsősorban Angolát, Elefántcsontpartot, Sierra Leonet, Libériát, Guineát és Bissau-Guineát érinti.

Természetesen, az illegális bányászat és ásványkereskedelem bonyolult társadalmi, emberi jogi, környezeti vonatkozásit jelen keretek között nem lehetséges kifejteni, azonban

\footnotetext{
${ }^{64}$ Shasta Darlington: Illegal Mining, 'Worse Than at Any Other Time,' Threatens Amazon, Study Finds. The New York Times, 2018. december 10. https://www.nytimes.com/2018/12/10/world/americas/amazonillegal-mining.html (2019. 07. 25.).

Vonatkozó tanulmány: https://illegalmining.amazoniasocioambiental.org/story (2019. 07. 25.).

65 Aaron Ross: Send in the troops: Congo raises the stakes on illegal mining. 2019. július 17. https://www.reuters.com/article/us-congo-mining-insight/send-in-the-troops-congo-raises-the-stakes-onillegal-mining-idUSKCN1UCOBS (2019. 07. 25.).

${ }^{66}$ Blood diamonds, conflict diamonds, war diamonds, hot diamonds, red diamonds: olyan gyémánt, amelyet polgárháborús, illetve fegyveres konfliktusok által sújtott területeken bányásznak és elsősorban hadúrak célok támogatására, fegyvervásárlásra és egyéb, hasonló célokra használnak fel.
} 
nyilvánvalóan megállapítható, hogy a környezeti büncselekményeket általában jellemző elemek: a korrupció, a szervezett bünözés, környezetrombolás, destabilizációs hatások, itt is megállapíthatók.

\section{A jogszabályok megsértésével véghez vitt fakivágás és erdöirtás - erdészeti büncselek- mények}

A jogellenesen folytatott fakitermelési tevékenység pontos mértékét nehéz megbecsülni, azonban egy 2004-ben készült átfogó jelentés szerint a világon forgalomban lévő fatermékek alapanyagának mintegy 10 százaléka ilyen módon került megszerzésre. ${ }^{67}$ Becslések alapján megállapítható, hogy évente 100 millió négyzetméternyi fa kerül illegálisan kivágásra, elsősorban a trópusi területeken, ahol értékes és ritka fafajokat irtanak (pl. Brazília és az Amazonsas vidéke, Ghána, Indonézia). ${ }^{68}$ Az erdőírtásnak súlyos környezeti és társadalmi hatásai vannak. A környezeti hatások között meg lehet említeni a védett állatés növényfajok túlélési esélyeinek romlását, a klímaváltozás elősegítését, hiszen az erdőknek köszönhető a légkörben található szén-dioxid mennyiség csökkenése. A társadalmi hatások is szintén jelentősek, így az állami és földtulajdonosi bevételek csökkenése, az őshonos közösségek jogainak sérelme, ráadásul a jogellenes fakitermelés és a szervezett bűnözés, valamint a korrupció közötti összefüggések is megállapításra kerültek. ${ }^{69} \mathrm{Az}$ előbbiekre tekintettel 1994-ben fogadták el a trópusi faanyagokról szóló nemzetközi megállapodást (majd ugyanazon tárgyban 2006-ban), amely azonban nem ír elő büntetőjogi következményeket. ${ }^{70} \mathrm{Az}$ értekezés fő témájaként szolgáló, vadvilági kereskedelemhez kötődően meg kell jegyezni a CITES-hez valódi kapcsolódási pontot, mivel a függelékek körében egyes - föként trópusi - fafajok is felsorolásra kerültek, amelyek így a Washingtoni Egyezmény által meghatározott védelemben is részesülnek.

67 "Illegal" Logging and Global Wood Markets: The Competitive Impacts on the U.S. Wood Products Industry. Seneca Creek Associates, LLC, 2004.

http://www.unece.lsu.edu/responsible_trade/documents/2003-2006/rt03_036.pdf (2019. 07. 25.).

${ }^{68}$ Scale of illegal logging https://www.illegal-logging.info/topics/scale-illegal-logging\%20 (2019. 07. 25.).

${ }^{69}$ Major impacts https://www.illegal-logging.info/TOPICS/MAJOR-IMPACTS (2019. 07. 25.).

${ }^{70}$ International Tropical Timber Agreement. Nemzetközi Trópusifa Megállapodás. 1994. (1997.) UNTS Vol. 1955, 81. p., majd a 2006. évi ugyanazon tárgyban elfogadott megállapodás. Utóbbit Magyarországon kihirdette: 4/2012. (II. 16.) Korm. rendelet. 


\section{A vadon élö állat- és növényfajokkal folytatott jogellenes kereskedelem}

A vadon élő állat- és növényfajokkal folytatott kereskedelmi tevékenység még részletesen ismertetem az értekezés későbbi fejezeteiben. Ezért jelen esetben csak rövid utalás történik arra, hogy a környezet elleni büncselekmények körében a vadvilági egyedekkel, termékekkel folytatott kereskedelem az egyik kiemelt tevékenységnek tekinthető, hiszen napjainkban eddig sohasem látott mértéket ért el. A vadvilági kereskedelem lehet legális és illegális. Alappal feltételezhetnénk, hogyha a fajokat jelentős mértékben negatív irányba befolyásolja a kiaknázás, egyáltalán nem beszélhetünk jogszerü tevékenységről. Azonban a nemzetközi és az erre épülő egyéb szabályozás elsősorban nem a tiltást, hanem a jogszerü keretek közé szorítást helyezi előtérbe és csak ultima ratio jelleggel találunk kizáró normákat. A vadvilági kereskedelem államhatárokon átívelő jelenség, mivel a vadvilági termékek felvevőpiaca elsősorban az Európai Unió területe, az Amerikai Egyesült Államok és Ázsia egyes országai, míg a kínálat a fejlődő államokból indul útjára. Az illegális vadvilági kereskedelem a vadvilággal kapcsolatos bűncselekmények leggyakoribb megvalósulási módja. A természeti környezetből befogott, begyüjtött élö egyedeket vagy belőlük készült termékeket korrupt nemzeti hatóságok közremüködésével, valamint bejáratott csempészútvonalakon juttatják el a felvevőpiac országaiba. Az illegális vadvilági termékek általában nagy távolságot tesznek meg, mire a forráshelyről eljutnak a célállomásig. A vadvilági kereskedők ehhez kihasználják a globális szállítmányozás növekvő ütemü összekapcsolását, és az olyan új csatornákat, mint az online kereskedelem és piacok. Továbbá, a végrehajtó hatóságok munkájának hiányosságai és a kikényszerítés alacsony müködési hatékonysága csökkentik a lebukás veszélyét. Ennek a felismerése vezetett a ROUTES - a veszélyezettet fajok jogellenes szállítási lehetőségének csökkentéséért - összefogás létrehozásához. A 2015 és 2020 közötti első müködési időszakban a nemzetközi szállítmányozási szektor és az USA kormányának együttműködésével ${ }^{71}$ igyekszik gátat szabni az egyre növekvő ütemű illegális vadvilági kereskedelemnek. ${ }^{72}$

\footnotetext{
${ }^{71}$ A ROUTES (Reducing Opportunities for Unlawful Transport of Endangered Species) együttmüködésben részt vesznek: Amerikai Egyesült Államok kormánya és a szállítmányozási szektor képviselői, mint a Center for Advanced Defense Studies (C4ADS), Freeland, a Nemzetközi Légi Szállítási Szövetség (International Air Transport Association - IATA), TRAFFIC és WWF (World Wildlife Fund).

${ }^{72}$ Welcome to ROUTES http://routespartnership.org/ (2019. 03. 29.).
} 
Veszélyes és toxikus anyagok illegális elhelyezése és azokkal való kereskedelem; ózonkárosító anyagokkal folytatott kereskedelem

A szennyezés jellemzően együtt jár a legtöbb termelőtevékenységgel, azonban annak mértéke több esetben is visszafordíthatatlan környezeti károkhoz vezetett. Az államok felismerve, hogy egyes anyagok különösen veszélyesek az emberre és a természetre, jogszabályalkotással igyekeztek gátat szabni azok felhasználásának. A hulladékokra és a veszélyes hulladékokra vonatkozó jogi normák pedig végül önálló területét képzik a környezetjogi szabályozásnak. A környezet elleni büncselekmények körében az említett veszélyes és toxikus, szennyező anyagok jogellenes elhelyezése és kereskedelme fontos helyet foglal el. Mivel jelen értekezésnek nem célja, hogy részletesen tárgylásra kerüljenek a vonatkozó cselekmények, azok részletes kifejtésétől eltekintek és csak a releváns nemzetközi egyezmények megnevezésére szorítkozok. A tengerszennyezésekre vonatkozóan már az ENSZ tengerjogi egyezménye is tartalmaz rendelkezéseket. ${ }^{73}$ A tengerszennyezésre vonatkozóan mindenképpen meg kell említeni az ún. MARPOL egyezményt, a hajókról történő szennyezés megelőzéséről és az ahhoz csatolt 1978. évi Jegyzőkönyvet. ${ }^{74}$ Hajókról történő szennyezés kapcsán fogadták el a Londoni Egyezményt, majd 1996-ban az ahhoz füzött kiegészítő Jegyzőkönyvet. ${ }^{75}$ Kifejezetten a felelősség kapcsán is létrejöttek nemzetközi jogi instrumentumok, így elsősorban az olajszennyezéssel kapcsolatos károkra vonatkozóan. ${ }^{76} \mathrm{~A}$ veszélyes hulladékok szállítása is súlyos környezeti kockázatokat hordoz, így ennek kapcsán is egyezményalkotásra került sor. ${ }^{77}$ A vegyi anyagok és az azt felhasználó különösen veszélyes létesítmények kapcsán került elfogadásra az ipari

\footnotetext{
${ }^{73}$ United Nations Convention on the Law of the Sea. ENSZ tengerjogi egyezménye. 1982. (1994.) UNTS Vol. 1833, 3. p. (Magyarországon nincs kihirdetve.).

${ }^{74}$ Protocol of 1978 relating to the International Convention for the prevention of pollution from ships. A hajókról történő szennyezés megelőzéséről szóló 1973. évi egyezmény és az ahhoz csatolt 1978. évi Jegyzőkönyv (MARPOL 1973/1978.). 1973. 1978. (1983.) UNTS 1340 (p.61), 1341 (p.3) Magyarországon kihirdette: 2001. évi X. törvény.

${ }^{75}$ Convention on the prevention of marine pollution by dumping wastes and other matter. A hulladékkal és egyéb anyagokkal való tengerszennyezés megelőzéséről szóló egyezmény. 1972. (1975.) UNTS Vol. 1046. 139. p. Magyarországon kihirdette: 1976. évi 20. tvr. London Protocol 1996. (2006.).

${ }^{76}$ International Convention on Civil Liability for Oil Pollution Damage. UNTS Vol. 973. 3. p. 1969. (1975.) Protocol: 1992. (1996.) Amendment: 2000. (2003.) Az olajszennyezéssel okozott károk megtérítésére szolgáló nemzetközi alap létrehozásáról szóló 1992. évi egyezmény, az ahhoz elfogadott 2003. évi jegyzőkönyv és az olajszennyezéssel okozott károkkal kapcsolatos polgári jogi felelősségről szóló 1992. évi egyezmény. Magyarországon kihirdette: 2007. évi IX. törvény.

International Convention on Civil Liability for Bunker Oil Pollution Damage. A bunkerolaj-szennyezéssel okozott károkkal kapcsolatos polgári jogi felelősségről szóló egyezmény. 2001. (2008.) Magyarországon kihirdette: 2007. évi CLXV. törvény.

${ }^{77}$ Basel convention on the control of transboundary movements of hazardous wastes and their disposal. Bázeli Egyezmény a hulladékok határokon túlra történő szállításának és ártalmatlanításának ellenőrzéséről. 1989. (1992.) UNTS Vol. 1673. 57. p. Magyarországon kihirdette: 101/1996. (VII. 12.) Korm. Rendelet.
} 
balesetek országhatáron túli hatásairól szóló, Helsinkiben, 1992. március 17-én kelt Egyezmény és 2003-ban az az Kiegészítő felelősségi Jegyzőkönyv. ${ }^{78}$ Az ózonréteg védelme érdekében fogadták el a Bécsi Egyezményt ${ }^{79}$ és az ahhoz kapcsolódó kiegészítő jegyzőkönyveket, amelyek közül a legismertebb a Montreáli Jegyzőkönyv. Utóbbi nem kimerítő felsorolás arra mutat rá, hogy számos multilaterális környezeti tárgyú egyezmény fogadtak el, amelyek egy jelentős része felelősségi, illetve jogkövetkezményekre vonatkozó szabályokat is meghatároz.

A környezeti büncselekmények közös jellemzője, hogy azok az államok belső jogi szabályozása alapján büntetendők, azonban a hangsúly egyre inkább azok nemzetközi jelentőségére helyeződik. Így azonosítható a határon átnyúló szervezett bünözéssel, korrupcióval, pénzmosással és csalással való kapcsolat, amely természetesen a vonatkozó nemzetközi egyezmények minél szélesebb körü elfogadását és alkalmazását is megköveteli. A környezeti büncselekmények elleni hatékony fellépésnek sokszor gátat szab, hogy ártalmatlan vagy áldozat nélküli cselekményként tekintenek rájuk. Hiszen sokszor a tevékenység eleve rejtetten marad és a rendvédelmi, később az igazságszolgáltató szervek figyelmét is elkerülik a jogellenes, környezetromboló cselekmények. ${ }^{80} \mathrm{~A}$ vadvilággal kapcsolatos büntetendő cselekmények több nemzetközi egyezmény alkalmazását is felvetik: az ENSZ keretében elfogadott szervezett bünözés és korrupció elleni egyezmények, valamint a Washingtoni Egyezmény hatékony végrehajtása utat mutathat a bünelkövetés viszszaszorításához. A szervezett bünözés egyéb formáit tekintve, mint a drog- és fegyverkereskedelem, az emberkereskedelem és csempészet, találunk nemzetközi szabályozási eszközöket. Azonban nincsen egységes megállapodás a vadvilághoz kötődő büncselekmények fogalmában, így univerzálisan elfogadott definíciót nem adhatunk. Ez azonban nem jelenti azt, hogy a vadvilág ne lenne nemzetközi szinten is védelem alá helyezve, azonban más forrásokhoz kell folyamodni. Az egységes meghatározás kialakítását nehezíti, hogy

\footnotetext{
${ }^{78}$ Convention on the Transboundary Effects of Industrial Accidents. Az Egyesült Nemzetek Szervezetének Európai Gazdasági Bizottsága keretében létrejött, az Ipari Balesetek Országhatáron Túli Hatásairól szóló, Helsinkiben, 1992. március 17-én kelt Egyezmény. 1992. (2000.) UNTS Vol. 2105. 457. p. Magyarországon kihirdette: 128/2001. Korm. Rendelet.

Protocol on Civil Liability for Damage and Compensation for Damage Caused by Transboundary Effects of Industrial Accidents on Transboundary Waters. 2003. (Nincs hatályban.).

79 Vienna Convention for the Protection of Ozone Layer. Egyezmény az ózonréteg védelméröl. 1985. (1988.) UNTS Vol. 1513. 293. p. Magyarországon kihirdette: 31/1990. (II. 16.) MT rendelet.

The Montreal Protocol on Substances that Deplete the Ozone Layer. Az ózonréteget lebontó anyagokról szóló, Montreálban 1987. szeptember 16-án aláírt jegyzőkönyv. 1987. (1989.) UNTS Vol. 1522. 30. p. Magyarországon kihirdette: 35/1990. (II. 28.) MT Rendelet.

${ }^{80}$ Evironmental crimes http://www.unicri.it/topics/environmental/ (2019. 05. 04.).
} 
minden egyes állam nemzeti szabályozása keretében helyezi védelem alá az országon belül honos állat- és növényvilágot. ${ }^{81}$

Az értekezés további fejezeteiben a védett (veszélyeztetett), vadon élő állat- és növényfajokkal kapcsolatos fogalmi kérdéseket vizsgálom, majd kifejezetten a kereskedelmi tevékenység jogszerü és jogellenes formáit, a felvetett nemzetközi közjogi problémákat. Ahhoz, hogy a vadvilágot érintő büntetendő cselekmények fogalmi elemeit azonosíthassam, meg kellett vizsgálnom az ENSZ vonatkozó határozatait. Utóbbiak jelentősége abból adódik, hogy a nemzetközi közösség az elmúlt egy évtizedben élénken foglalkozott a téma alapját szolgáló cselekmények negatív környezeti, társadalmi hatásaival, így azok vizsgálata megkerülhetetlen.

${ }^{81}$ Defining transnational organized wildlife crime. $1 . \mathrm{p}$. https://www.unodc.org/documents/data-and-analysis/wildlife/WLC16_Chapter_1.pdf (2019. 03. 29.). 


\section{III.2. A vadvilággal kapcsolatos büncselekmények az ENSZ fo- galmi rendszerében}

Annak érdekében, hogy megértsük, a nemzetközi közösség hogyan közelít a környezetet károsító és a vadvilágot, biodiverzitást hátrányosan befolyásoló cselekmények felé, meg kell vizsgálni az ENSZ említett területen elfogadott határozatait. Az ENSZ keretében több föszerv is foglalkozott a vadvilággal kapcsolatos büncselekmények, kiemelten a kereskedelem kérdésével. Az Egyesült Nemzetek Szervezetéhez kötődő határozatok érdemi vizsgálata több szempontból sem megkerülhető a téma és a fogalomalkotás szempontjából. Elsősorban, mivel egységes jogi fogalomról nem beszélhetünk, meg kell határozni, hogy a nemzetközi közösség mit ért a vadvilággal kapcsolatos büntetendő cselekmények körén. Továbbá, az egyes fogalmi elemek - mint a szervezett bünözési elem és a korrupcióra való hajlandóság - szintén kiemelésre kerülnek az ENSZ határozataiban, megerösítve azok fontosságát. Végül, a vadvilágot és a környezetet pusztító büncselekmények elleni harc egyik fő támogatója az ENSZ és különösen az ENSZ Környezeti Programja, valamint a UNODC. Így megkerülhetetlen annak vizsgálata, hogy az érintett szervek, szervezetek mit értenek a vizsgált cselekmények alatt. Az ENSZ főszervei által hozott határozatokra jellemzők, hogy kitérnek a büncselekmények jelentőségére, gyakorlati példákkal szemléltetve azt. További elemek a szervezett bünözéshez és egyéb vonatkozó cselekményekhez kötődnek, mint a korrupció, valamint a releváns nemzetközi egyezmények minél szélesebb körü ratifikációjára való felhívás is megjelenik. Éppen ezért a határozatokban a gyakorlati és nemzetközi jogi elemek keveredve találhatók meg.

A Közgyülés többször is tárgyalásra tüzte az érintett cselekmények körét. 2015-ben fogadták el a jogellenes vadvilági kereskedelem megoldása érdekében hozott határozatot. ${ }^{82}$ A Közgyülés utal az orvvadászat és a jogellenes vadvilági és vadvilági termékekkel folytatott kereskedelem növekvő mértékére, és azok visszafordíthatatlan gazdasági, társadalmi és környezeti hatásaira. Külön kiemelésre került a rinocéroszok és afrikai elefántok orvvadászata, amely a kihalás szélére sodorta az érintett fajokat. A Közgyülés külön aggodalmát fogalmazta meg a szervezett bünözés egyre nagyobb arányú részvétele miatt, amely még fenyegetőbbé teszi a védett fajok illegális kereskedelmét. ${ }^{83}$

\footnotetext{
82 A/RES/69/314 (2015. augusztus 19.) Tackling illicit trafficking in wildlife [Továbbiakban: A/RES/69/314].

${ }^{83} \mathrm{~A} / \mathrm{RES} / 69 / 314$ 1. p.
} 
A 2015-ben elfogadott határozatot követően a Fötitkár 2016-ban adta ki jelentését ${ }^{84}$ az abban foglaltak végrehajtásáról. A jövőre vonatkozó javaslatok között szerepel a végrehajtási szervezetrendszer és a bűnügyi igazságszolgáltatás megerősítése, az állami szervek és kormányközi nemzetközi szervezetek, valamint a privát szféra közötti együttmüködés a minél hatékonyabb kikényszerítés és felderítés érdekében. Nemzeti szinten meg kell erősíteni a pénzmosásra, korrupcióra, csalásra és egyéb pénzügyi büncselekményekre vonatkozó jogszabályokat. A jelentés külön felhívja az államok figyelmét a szervezett bünözés és korrupció elleni nemzetközi egyezmények ratifikációjára, amely a szervezett bűnözés felszámolása érdekében kiemelkedően fontos lépésnek tekinthető. ${ }^{85}$

A Közgyülés 2016 szeptemberében határozatban ${ }^{86}$ hívta tárgyalásra a feleket - a CITES Titkárság együttmüködésével - a 2017 márciusában tartott nemzetközi konferenciára. A határozatban a Közgyülés újfent kiemelte a biológiai sokféleség értékét és annak kapcsolatát a fenntartható fejlődéssel és az emberi jólléttel. ${ }^{87}$

A Közgyülés 2017-ben fogadott el legutóbb határozatot ${ }^{88}$ az illegális vadvilági kereskedelem témakörében. A Közgyülés az említett dokumentumban aggodalmát fejezte ki a minden eddigi mértéket meghaladó afrikai rinocérosz és elefánt orvvadászat miatt. A Közgyülés elismerte, hogy a jogellenes vadvilági kereskedelem károkat okoz az ökoszisztémában és az élőhelyekben, beleértve az ökoturizmust, aláássa a jó kormányzást és a jog érvényesülését és néhány esetben a fenyegeti a nemzetközi stabilitást. Éppen ezért válaszként megerősített nemzetközi összefogásra és regionális együttmüködésre van szükség. A határozatban megjelenik az online kereskedelem és kiberbüncselekmények aggasztó növekedése az illegális vadvilági kereskedelem területén, illetve a hamisított vagy jogellenesen felhasznált engedélyek által hordozott nehézségek. ${ }^{89}$ Újra kiemelésre kerül, hogy az államok ratifikálják az ENSZ keretében elfogadott vonatkozó egyezményeket, amelyek nélkül a TOC elleni harc elképzelhetetlen. ${ }^{90}$

\footnotetext{
${ }^{84}$ A/70/951 (2016. június 16.) Tackling illicit trafficking in wildlife. Report of the Secretary-General [Továbbiakban: $\mathrm{A} / 70 / 951]$.

${ }^{85} \mathrm{~A} / 70 / 951$ 17-19. p. 54-57. bekezdések.

${ }^{86} \mathrm{~A} / \mathrm{RES} / 70 / 301$ (2016. szeptember 09.) Tackling illicit trade in wildlife [Továbbiakban: A/RES/70/301].

${ }^{87} \mathrm{~A} / \mathrm{RES} / 70 / 301$ 2. p. 5. bekezdés.

88 A/RES/71/326 (2017. szeptember 28.) Tackling illicit trafficking in wildlife [Továbbiakban: $\mathrm{A} / \mathrm{RES} / 71 / 326]$.

${ }^{89} \mathrm{~A} / \mathrm{RES} / 71 / 326$ 2. p.

${ }^{90} \mathrm{~A} / \mathrm{RES} / 71 / 326$ 4. p.
} 
A vadvilági bünözés elharapózó mértéke a Biztonsági Tanács figyelmét is felkeltette, így 2015-ben ${ }^{91}$ és 2016-ban ${ }^{92}$ is határozatban foglalkoztak azzal. A 2015-ben közrebocsátott elnöki állásfoglalás ${ }^{93}$ nyomán a BT hosszasan vizsgálta a Kongói Demokratikus Köztársaságban a vadvilággal kapcsolatos büncselekmények destabilizáló hatásait. A KözépAfrika térségében kibontakozó instabilitás és a különböző fegyveres milíciák erősödése, térnyerése mély aggodalomra ad okot. A Biztonsági Tanács határozatai nyomán kibontakozó kutatások megerősítették, hogy számos esetben az említett csoportok és a hivatásos katonaság egyes tagjai is ${ }^{94}$ a természeti erőforrások - mint például az ásványok - illegális kiaknázásából és csempészetéből, orvvadászatból és fabrikett előállításából finanszírozzák egyéb tevékenységüket (pl. fegyvervásárlás). Éppen ezért a BT arra bátorítja a Kongói Demokratikus Köztársaság vezetőjét, hogy vonják felelősségre a fegyveres csoportok és a rendvédelmi szervek azon tagjait, akik a vadvilágot károsító cselekmények elkövetőinek tekinthetők. ${ }^{95}$ Ugyanez a jelenség megtalálható a Közép-Afrikai Köztársaságban is, ahol a természeti erőforrások - beleértve az aranyat is - illegális kiaknázása, kereskedeleme és csempészete negatív hatással van az ország fejlődésére és gazdaságára és fenyegeti az ország békéjét, stabilitását. ${ }^{96}$ A Biztonsági Tanács határozata egyértelmű kapcsolatot tárt fel a Közép-Afrikai Köztársaság területén aktívan müködő LRA ${ }^{97}$ és olyan szervezett bünözői csoportok között, amelyek természeti erőforrások, köztük gyémántés aranykereskedelemmel és orvvadászattal tesznek szert haszonra. ${ }^{98}$

A Gazdasági és Szociális Tanács először 2001-ben, majd 2003-ban is hozott határozatokat $^{99}$ a védett állat- és növényfajok illegális kereskedelméröl. 2008-ban pedig kifejezetten az erdészeti termékek és biológiai erőforrásokra vonatkozóan ${ }^{100}$ fogadtak el határozatot. A 2001-ben hozott határozatot követően 2002-ben készült jelentés ${ }^{101}$ az abban foglaltak megvalósulásáról. A jelentésben kiemelésre kerül, hogy az előzetes bizonyítékok alapján megállapítható a védett fajok kereskedelmének erőteljesen szervezett volta. Az állatokkal

\footnotetext{
${ }^{91}$ S/RES/2198 (2015. január 29.) [Továbbiakban: S/RES/2198].

92 S/RES/2262 (2016. január 27.) [Továbbiakban: S/RES/2262].

${ }^{93}$ Statement by the President of the Security Council 2015. június 21.

${ }^{94}$ FARDC: Congolese Armed Forces.

95 S/RES/2198 7. p.

96 S/RES/2262 3. p.

${ }^{97}$ Lord's Resistance Army (LRA).

${ }^{98}$ S/RES/2262 3. p.

${ }^{99}$ ECOSOC Resolutions 2001/12 (2001. július 24.) és 2003/27 (2003 július 22.).

${ }^{100}$ ECOSOC Resolution 2008/25 (2008. július 24.).

${ }^{101}$ E/CN.15/2002/7 (2002. február 26.) Progress made in the implementation of Economic and Social Council resolution 2001/12 on illicit trafficking in protected species of wild flora and fauna. Report of the Secretary-General [Továbbiakban: E/CN.15/2002/7].
} 
és növényekkel folytatott kereskedelem kevésbé költséges és kockázatos tevékenység, mint a drogkereskedelem, azonban nagy haszonra lehet vele szert tenni. A porrá őrölt rinocéroszszarv többet érhet, mint az ugyanolyan mennyiségű heroin vagy kokain. A ritka papagájok eladása több tízezer USD hasznot hozhat az amerikai piacon. A figyelem alacsony és a büntetések mérsékelt volta felkeltette a szervezett bünözői csoportok figyelmét. Megállapítható, hogy a vadvilági bünözésböl befolyó hasznot sokszor terrorszervezetek, vagy más fegyveres csoportok támogatására használják fel. Ugyancsak összefüggés állapítható meg a vadvilágból származó egyedek vagy termékek csempészete és a drogkereskedelem között, különösen Latin-Amerika térségében. A „Cali” drogkartell bizonyíthatóan vegyes szállítmányokat küldött Kolumbiából az Amerikai Egyesült Államokba, ahol a vadvilági és drogtermékeket keverték össze egymással. Más esetek is bizonyításra kerültek, például Elefántcsontpartból Izraelbe papagájokat szállítottak vegyesen droggal. Egy brazíliai hálózat megállapításai szerint 400 bűnözői kör érintett állatcsempészetben, ebből mintegy negyven százalék más büncselekményekben is érdekelt, elsősorban drogkereskedelemben. Egy ismert esetben a heroint élő boákba tömték és így szállították. Az USA „Fish and Wildlife Service” megállapításai szerint a pénzmosás egy speciális formája is kialakult, amikor az ügylet készpénzforgalomtól mentesen zajlik, mivel veszélyeztetett fajokat cserélnek ki drogra. Más megállapítások szerint azonban a hagyományosan drog-, fegyver- és emberkereskedelemmel foglalkozó csoportok csupán érintőlegesen folynak bele a vadvilággal kapcsolatos büntetendő cselekményekbe, azt elsősorban önálló, sokszor egyébként jogszerü kereskedelemet is folytató személyek bonyolítják. A téma összetettsége és sokszínüsége folytán a szervezett bünözői csoportok négy különböző formában lehetnek részesei a veszélyeztetett fajok kereskedelmének. Elsősorban a széles portfólióval rendelkező szervezett bünözői csoportok egyik tevékenysége - kifejezetten profitkalkuláció alapján - a veszélyeztetett fajok kereskedelme. Így például a kínai maffia gyakran bonyolódik ilyen ügyeletekbe a tradicionális medicina miatt jelentkező igényeket ellátva. Másodsorban, a kifejezetten csempészhálózatok üzemeltetésében résztvevő csoportok, szintén egyik altevékenységként foglalkoznak a jogellenes kereskedelemmel. Például a 90-es években az egykori Szovjetunió térségében müködő hálózat csempészett nőket és tigriseket is Nyugat-Európába. Harmadsorban, egyes csempészhálózatok, amelyek a jogszerü kereskedelem mintája alapján végzik tevékenységüket, kifejezetten a veszélyeztetett fajokra koncentrálva müködnek. Végül, egyes egyébként legálisan működő személyek vagy szervezetek végeznek jogellenes kereskedelmet 
is olyan igények kielégítése végett, mint a magánszemélyektől vagy akár gátlástalan állatkertektől, parkoktól érkező megrendelések. ${ }^{102}$

A 2003-ban elfogadott határozat ${ }^{103}$ nyomán 2005-ben készült jelentés kifejezetten a nemzetközi együttmüködést és összefogást hangsúlyozza, amely nélkül nem lehetséges hatékony fellépés a jogellenes vadvilági kereskedelem leküzdése érdekében. ${ }^{104}$

A Gazdasági és Szociális Tanács 2011-ben a vadon élő veszélyeztetett fajok illegális kereskedelme elleni bünmegelőzés és büntető igazságszolgáltatási válaszokkal kapcsolatosan hozott határozatot. ${ }^{105} \mathrm{~A}$ dokumentum arra hívja fel a figyelmet, hogy a veszélyeztetett állat- és növényfajokkal folytatott jogellenes kereskedelem minden aspektusában megfigyelhető a szervezett bünözői csoportok részvétele. Ezzel kapcsolatosan pedig utal a szervezett bünözés és a korrupció ellen elfogadott egyezmények hasznosságára. Továbbá, a határozat kiemeli az ICCWC jelentőségét, elismerve annak munkáját mind regionális, mind nemzetközi szinten. Végül, a UNODC-t hívja fel együttmüködésre a releváns nemzetközi szervezetekkel és államokkal. ${ }^{106}$ Ahhoz, hogy az ENSZ szerevezett bünözés ellen elfogadott egyezményét alkalmazni lehessen a vadvilággal kapcsolatos büntetendő cselekményekre, szükséges, hogy az államok az érintett bűncselekményeket súlyos büncselekménynek minősítsék. Enélkül azok nem tartozhatnak az egyezmény alkalmazási körébe. Erre hívja fel az államok figyelmét a határozat is, mikor nem csupán az egyezmény ratifikációjára sarkallja őket, hanem az egyes, környezetet érintő cselekmények súlyos büncselekményként való minősítésére is. ${ }^{107}$

Az előbbieket erősíti meg az ECOSOC 2013-ban, a Bűnmegelőzési és Büntető Igazságszolgáltatási Bizottság ${ }^{108}$ ajánlására elfogadott határozata ${ }^{109}$ is. Az ECOSOC újra kifejezte aggodalmát a szervezett bűnözői csoportok részvétele miatt a vadvilágot érintő bűncselekményekben és kijelentette, hogy a védett, vadon élő állat- és növényfajokkal való jogellenes kereskedelem a határon átnyúló szervezett bünözés egyre inkább kifinomult

\footnotetext{
102 E/CN.15/2002/7 C Involvment of organized criminal groups 6-7. p.

${ }^{103}$ ECOSOC Resolutions 2003/27 (2003 július 22.).

${ }^{104}$ E/CN.15/2005/10 (2005. március 17.) Illicit trafficking in protected species of wild flora and fauna. Report of the Secretary-General.

105 ECOSOC Resolution 2011/36 (2001. július 28.) on Crime prevention and criminal justice responses against illicit trafficking in endangered species of wild fauna and flora [Továbbiakban: ECOSOC Resolution 2011/36].

${ }^{106}$ ECOSOC Resolution 2011/36 2. p.

${ }^{107}$ ECOSOC Resolution 2011/36 3. p. 4-5. bekezdések.

108 The Commission on Crime Prevention and Criminal Justice.

${ }^{109}$ ECOSOC Resolution 2013/40 (2013. október 17.) on Crime Prevention and criminal justice responses to illicit trafficking in protected species of wild fauna and flora [Továbbiakban: ECOSOC Resolution 2013/40].
} 
formája. Az illegális kereskedelem destabilizáló hatással van a nemzeti gazdaságra és a helyi közösségekre, beleértve a természetes élőhelyek pusztítását, a sérülékeny és veszélyeztetett fajok eltűnését és kihalását. ${ }^{110}$

Az ENSZ Bünmegelőzési és Büntetö Igazságszolgáltatási Bizottsága már 2007-ben ${ }^{111}$ is foglalkozott az illegális nemzetközi kereskedelemmel, akkor kifejezetten az erdészeti termékekre fókuszálva. 2014 májusában megtörtént az említett határozat folytatása, amikor is a célzott bűnmegelőzés és büntető igazságszolgáltatási válasz megerősítéséről fogadtak el határozatot. ${ }^{112}$ Ugyanakkor általánosan utalás történik arra, hogy az államok mindent tegyenek meg a szervezett bünözés elleni harc érdekében és alkalmazzák a vadvilággal kapcsolatos büntetendő cselekményekről és erdészeti bűncselekményekről szóló elemző eszközkészletet. ${ }^{113}$

Az ENSZ Környezeti Programja is többször tárgyalásra tüzte az illegális vadvilági kereskedelem témáját. A UNEP a 2014-es év folyamán részletesen kitért a vadvilági kereskedelemre. Ebből a szempontból legjelentősebb az ott elfogadott 1/3-as határozat, amelyet 2016-ben követett az ahhoz kapcsolódó jelentés. Később, 2016 májusában került elfogadásra a 2/14-es határozat, amely a 2014-ben kelt 1/3-as határozatra épül. A UNEP is kiemeli, hogy a vadvilági egyedekkel és termékekkel folytatott illegális kereskedelem és más büncselekmények negatív hatással vannak a környezetre és azokat egyre inkább határon átnyúló szervezett bünözői csoportok követik el és ösztönzi az államokat a releváns nemzetközi egyezményekhez való csatlakozásra, az 1/3-as határozat rendelkezésének végrehajtására. ${ }^{114}$ A 2/14-es határozat sürgeti a tagállamokat, hogy tegyenek további lépéseket nemzeti szinten, valamint regionális és nemzetközi együttmüködés keretében a vadvilági egyedek és termékek jogellenes kereskedelme megelőzése és megszüntetése érdekében, beleértve az azokra való keresletet, szállítást és kínálatot. Utóbbiakat megfelelő akcióprogramok és stratégiák állami szintű megvalósításával, a vonatkozó kormányzati szervek megerősítésével, a már létező nemzetközi és regionális együttműködések

\footnotetext{
${ }^{110}$ ECOSOC Resolution 2013/40 2-3. p.

${ }^{111}$ Resolution 16/1 (2007. április 07.) International cooperation in preventing and combating illicit international trafficking in forest products, including timber, wildlife and other forest biological resources

${ }^{112}$ Resolution 23/1 (2014 májusa) Strengthening a targeted crime prevention and criminal justice response to combat illicit trafficking in forest products, including timber [Továbbiakban: Resolution 23/1].

${ }^{113}$ Resolution 23/1 4. p. 7.

${ }^{114}$ UNEP/EA.2/L.15/Rev.1. (2016. május 26.) Illegal trade in wildlife and wildlife products 1.p.
} 
támogatásával (pl. ICCWC, African Elephant Action Plan) és az alternatív fenntartható közösségek támogatásával kell megvalósítaniuk. ${ }^{115}$

Az ENSZ Kábitószer-ellenőrzési és Bünmegelözési Hivatala a vadvilággal kapcsolatos és erdészeti büncselekmények elleni harc egyik központja lett az elmúlt egy évtizedben. A UNODC szoros együttmüködésben dolgozik az államokkal, az ENSZ ügynökségeivel, nemzetközi szervezetekkel, az NGO és a privát szektor képviselőivel, elsősorban DélÁzsia, Afrika, Közép- és Dél-Amerika területén, valamint a Karib térségben. Fő célkitüzései között szerepelnek a jogi szabályozás megerösítése, a végrehajtási szervezetrendszer kiépítése és hatékony müködése, az igazságszolgáltatás elősegítése. ${ }^{116}$

A fogalmi kérdések szempontjából megállapítható, hogy a UNODC a vadvilággal kapcsolatos és erdészeti büncselekmények alatt a vadon élő állat- és növényvilág (beleértve a faanyagot és más ilyen termékeket) bevételére, kereskedelmére, behozatalára, kivitelére, feldolgozására, birtoklására, megszerzésére és fogyasztására utal, ha az a nemzeti vagy nemzetközi jogi normák megsértésével történik. Tágabb értelemben tehát a vadvilággal kapcsolatos és erdészeti büncselekmények a világ vadon élő állat- és növényvilágának jogellenes kiaknázását jelentik. Továbbá, hangsúlyozásra került, hogy az említett büncselekmények szoros kapcsolatban vannak a korrupcióval, pénzmosással, erőszakos cselekményekkel és egyértelmüen kialakult azoknak határon átnyúló, szervezett bünözéshez kötődő formája. ${ }^{117}$

Az előbbiek alapján kijelenthető, hogy az ENSZ több főszerve is megállapította, hogy a vadvilági bűnözés olyan összetett jelenség, amelyben egyre inkább élen járnak a szervezett bünözői csoportok. Az jogellenes vadvilági kereskedelemből befolyó hasznot sokszor fegyveres- vagy akár terrorista csoportok más bűncselekmények - fegyvervásárlás, merényletek szervezése, toborzás, kiképzés - finanszírozására használják fel. Mivel a vadvilági termékek forrásországai sok esetben kevésbé fejlett vagy fejlődő államok, a természeti erőforrások ilyen formában történő kiaknázása elvezet a tervezett fejlesztések megvalósulásának elmaradásához, állami bevétel kieséshez és hozzájárul a térség destabilizációjához elvezetve a nemzetközi szintű biztonság gyengüléséhez.

${ }^{115}$ UNEP/EA.2/Res.14 (2016. augusztus 04.) Illegal trade in wildlife and wildlife products 2.p. 2. bekezdés (a)-(d) pontok.

116 UNODC Our Work https://www.unodc.org/unodc/en/wildlife-and-forest-crime/our-work.html (2019. 07. 26.).

117 UNODC Wildlife and forest crime https://www.unodc.org/unodc/en/wildlife-and-forest-crime/overview.html (2019. 07. 26.). 


\section{III.3. A vadvilággal kapcsolatos büntetendő cselekmények fogalmi elemei és jellemzői}

A környezeti büncselekményekkel kapcsolatosan már korábban utaltam arra, hogy az gyüjtőfogalom, amelynek egyik megvalósulási formája a vadvilággal kapcsolatos büncselekmények köre és azon belül tipikusan a jogellenes kereskedelemi tevékenység. Nem véletlen, hogy egységes fogalom eddig nem került meghatározásra, hiszen a vadvilágot károsító tevékenységek széles körét nem lehetséges tömören meghatározni. Jellemzően a környezet elleni büncselekményekre, a vonatkozó nemzetközi jogi instrumentumok tartalmaznak felelősségi vagy jogkövetkezményekkel kapcsolatos rendelkezéseket, de egységes megállapításokról itt sem beszélhetünk, hiszen minden egyes állam külön, nemzeti szabályozása keretében helyezi védelem alá az ott honos állat- és növényfajokat. A vadvilággal kapcsolatos büncselekményekre egységesen kialakított fogalom nem található, csupán azok az elemek és jellemzők tárhatók fel, amelyek szoros kapcsolódásuk révén tipikusan annak részét képezik. Így a fejezet célja, hogy kibontsa azokat a legfontosabb elemeket, amelyek jelenség megítélése során a jogban is megjelennek. Fontos megállapítani azt is, hogy bár a vadvilággal kapcsolatos büntetendő cselekményekre jellemző a határon átnyúló elem, azok nem feltétlenük a transznacionális szervezett bünözés keretében valósulnak meg. Továbbá, megalkottam egy olyan fogalmat, amelyet jelen értekezés keretében meghatározza, hogy mit értek a vadvilággal kapcsolatos büntetendő cselekmények körén.

A vadvilággal kapcsolatos büntetendö cselekmények alatt minden olyan, a vadonvilágra negatív hatással lévő cselekményt érteni kell, amelyeket az államok, nemzeti szabályozásuk keretében, hátrányos jogkövetkezménnyel sújtanak. Utóbbi cselekmények megvalósulhatnak a természetböl történő begyüjtéssel, bevétellel, kereskedelemmel, egy állam területére történő behozatallal vagy onnan történő kivitellel, birtoklással és megszerzéssel, feldolgozással. A vadvilághoz tartozik minden vadon élő állat- és növényfaj, beleértve azok minden előfordulási és együttélési formáját.

A vadvilággal kapcsolatos büncselekmények alapja a büntetőjogi jogkövetkezmények alkalmazása, a nemzeti jogszabályozás alapján. Jellemzőik között pedig megállapítható a határon átnyúló és a szervezett bünözési elem, valamint a korrupcióra való hajlandóság. 
Az egyes fogalmi elemek és jellemzök, amelyek részletes elemzésre kerülnek:

- a büntetőjogi elem, az egyes cselekmények büntetőjogi megítélése az államok jogi szabályozásában;

- a szervezett bünözés és a súlyos büncselekménynek való minősítés - a Palermói Egyezmény alkalmazásának kérdése;

- a korrupciós elem megjelenése - az ENSZ korrupció elleni egyezményének alkalmazása. 


\section{III.3.1. Az állami büntetőjog szerepe, a büntetni rendelés}

Ha végig tekintünk a környezetet és természetes közeget, a vadvilágot károsító cselekményeken, csak a legsúlyosabb esetekben találunk büntetőjogi jogkövetkezményeket. A nemzetközi egyezmények köre - és ez alól nem kivétel a CITES sem - a legtöbb esetben csak a hátrányos jogkövetkezmények alkalmazását írják elö. Azonban ott, ahol ténylegesen a környezet elleni büncselekményekröl és a vadvilággal kapcsolatos büncselekményekről van szó, megtalálhatóak az olyan, ultima ratio jelleggel alkalmazott szankciók is, mint a szabadságvesztés vagy akár a halálbüntetés. A nemzeti büntetőjog által alkalmazott hátrányos jogkövetkezmények köre is változatos tehát, így a pénzbüntetéstől kezdödően a szabadságelvonás különbözői formái is megtalálhatók. Azonban néhány állam egyre súlyosabb büntetésekkel igyekszik gátat szabni az elharapódzó orvvadászatnak. Nemrégiben Kenya vadvilágért és turizmusért felelős minisztere bejelentette, hogy az orvvadászatot a legsúlyosabb büncselekmények köré sorolják és az elkövető így halálbüntetéssel is sújtható lesz. ${ }^{118}$

A környezetet károsan befolyásoló cselekmények szankcionálásában helye van a különböző jellegü jogkövetkezményeknek, legyenek azok polgári jogiak, közigazgatási jogiak vagy büntetőjogiak. Nyilvánvalóan a legsúlyosabb szankciók csak végső esetben, a büntetőjogi minősítés esetében lesznek alkalmazhatók. Az sem kizárt, hogy a különböző jogágak következményeit egymás mellett alkalmazzák, például egy különösen súlyos szenynyezés maga után vonhatja a közigazgatási és a büntető igazságszolgáltatási rendszer párhuzamos eljárásait is.

Görgényi alapján a környezet elleni bűncselekmények megközelítésében helye van a büntetőjogi, a civil jogi és a közigazgatási jogi megközelítésnek is, azok külön-külön nem elégségesek és mindenképpen szükség van a „last resort”, vagyis a büntetőjog eszközrendszerére is. ${ }^{119}$ A Nemzetközi Büntetőjogi Kongresszus is foglalkozott a környezet elleni büncselekményekkel: „a mértékletesség elve alapján a büntető szankciók alkalmazására akkor kerüljön sor, amikor a polgári jogi és a közigazgatási jogi szankciók nem megfelelöek vagy hatástalanok bizonyos környezet elleni büncselekményekkel

\footnotetext{
${ }^{118}$ Kenya's death penalty plan for poachers has stirred a hornet's nest. 2018. május 22. $\mathrm{http}: / /$ theconversation.com/kenyas-death-penalty-plan-for-poachers-has-stirred-a-hornets-nest-96865 (2019. 05. 05.).

119 GÖRGÉNYI ILONA: Környezetvédelmi büntetőjog az európai elvárásokra figyelemmel. Agrár- és Környezetjog. 2018. 25. szám 64-67. p.
} 
szemben." ${ }^{120}$ Határozatukból tisztán kiolvasható, hogy a büntetőjog ténylegesen utolsó eszközként, a legsúlyosabb esetekben alkalmazható.

Az egyes államok nemzeti szabályozása között nagy különbségek vannak, egységességről a legkisebb mértékben sem beszélhetünk. Mivel sok esetben az adott, környezetet károsító cselekmény nem is számít büntetendőnek, az elkövetők élnek a ,forum shopping” adta lehetőségekkel és különböző államokban valósítják meg azokat. Így egy államban megtörténik az orvvadászat/beszerzés, másikban a kereskedelemre való elökészítés és egy további tranzitállam segítségével jut el a végső vásárlóhoz a termék, egyed vagy áru. Az egyes cselekmények megítélésében szigorúan figyelembe kell venni, hogy egyszeri, önállóan kivitelezett orvvadászatról van-e szó (pl. egy szarvas engedély nélküli kilövése) vagy egy szervezett bünözői csoport által irányított, a természetet, élőhelyeket szisztematikusan károsító tevékenységről, amelyet más büncselekmények finanszírozására is felhasználnak. ${ }^{121}$ Utóbbi gondolatot követve, nem mondhatjuk, hogy egy-egy vadon élő vagy akár védett egyed elpusztítása kevésbé számít büncselekménynek, azonban tény, hogy a nemzetközi szinten is figyelem tárgyát képezö, a kereskedelmi tevékenységet is magukba foglaló cselekmények, mindig nagy mértékben valósulnak meg. Utóbbi alatt azt kell érteni, hogy egyes fajok tömeges begyüjtése vagy megölése valósul meg (akár milliós nagyságrendben), amely nem fenntartható és elvezet a fajkihaláshoz. Az ilyen cselekmények jellemzően a szervezett bünözői kör segítségével valósulnak meg, a határon átnyúló elem is megfigyelhetö, valamint mindenképpen szükséges az adott állam gyenge végrehajtó szervezetrendszere, illetve a támogató jellegü korrupció.

A környezet büntetőjogi védelme nem számít újkeletünek, sem nemzeti, sem nemzetközi szinten. Azonban azok a kísérletek, amelyek a széles körü büntetni rendelést igyekeztek megvalósítani, nem vezettek el a várt eredményekhez. Ha a környezet büntetőjogi védelmének történetét nézzük, akkor érdemes az európai büntetőjog alakulását példaként említeni. Az Európa Tanács keretében 1998. novemberében fogadták el a környezet büntetőjogi védelméről szóló egyezményt, amely azonban mind a mai napig nincsen hatályban és a tizennégy aláíró állam közül mindösszesen egy ratifikálta. Magyarország nem írta alá és nem is ratifikálta, így az nem vált a magyar jog részévé. ${ }^{122}$ Az Európai Unió jogalkotása szempontjából azonban az egyezmény jelentősége vitathatatlan, hiszen annak

\footnotetext{
${ }^{120}$ Recommendation of Section I on Crimes against the environment. Application of the general part, in:XV.th International Congress of Penal Law, Rio de Janeiro, 4-10 September 1994, International Review of Penal Law, 1995/1-2, 50.

${ }^{121}$ The Rise of Environmental Crime 25. p.

${ }^{122}$ Convention on the Protection of Environment through Criminal Law. 1998. november 04. ETS No. 172.
} 
alapját képezte és az Európai Unió Tanácsának vonatkozó kerethatározatában ${ }^{123}$ utalás is történt a tanácsi szerződésre.

Az EU-ban hosszas vita alakult ki a környezet büntetöjogi védelmének szintjére tekintettel, amely leginkább arra irányult, hogy az érintett területet kerethatározatban vagy irányelvben szabályozzák-e. A probléma végül eljutott az Európai Unió Bírósága elé is, amely az uniós jog szempontjából kiemelkedő döntést hozott. ${ }^{124}$ Végül elfogadásra került az Európai Parlament és a Tanács 2008/99/EK irányelve (2008. november 19.) a környezet büntetőjog általi védelméről, amely a mai napig hatályos. ${ }^{125}$ Az irányelv elöírja, hogy az államok ,büntetőjogi szankciókat írjanak elő nemzeti jogszabályaikban a közösségi környezetvédelemi jog rendelkezéseinek súlyos megsértése esetére" és meghatározza azoknak a cselekményeknek a körét, amelyeket bűncselekménynek kell minősíteni. ${ }^{126}$ Jelen értekezés szempontjából jelentőséggel bír, hogy a védett, vadon élő állat- és növényfajokkal kapcsolatos egyes cselekmények büntetőjogi védelme is felsorolásra kerül az irányelvben. ${ }^{127}$ Kifejezetten a CITES kapcsán még megemlítem majd a magyar büntetőjog szerepét és a vonatkozó uniós jogforrások körét. Az Európai Unió a környezet védelmének magas szintjét valósítja meg, harmadik államokban ritkán valósul meg hasonló szintű szabályozás, talán az Amerikai Egyesült Államok kivételével. Az Európai Unió Bíróságának a környezetvédelmi büntetőjoggal foglalkozó, fent említett 2005-ben hozott ítéletében megállapított gyakorlata rögzült a Lisszaboni Szerződésben is. A jövőben lehet számítani az európai környezetvédelmi büntetőjog további egységesítésére és bővülésére. ${ }^{128}$ A nemzeti büntetőjog szerepe tehát vitathatatlan a vadvilággal kapcsolatos büncselekmények terén, hiszen a nemzeti büntetni rendelés nélkül nem beszélhetünk bűncselekményröl.

\footnotetext{
${ }^{123}$ A Tanács 2003/80/IB kerethatározata (2003. január 27.) a környezet büntetőjog általi védelméről (HL L 29., 2003.2.5., 55-58. p.) CELEX-szám: 32003F0080

${ }^{124}$ Európai Közösségek Bizottsága v Európai Közösségek Tanácsa C-176/03. sz. ügy, 2005. szeptember 13. ECLI:EU:C:2005:542.

${ }^{125}$ Az Európai Parlament és a Tanács 2008/99/EK irányelve (2008. november 19.) a környezet büntetőjog általi védelméről (HL L 328., 2008.12.6., 28-37. p.) CELEX-szám: 32008L0099 [Továbbiakban: 2008/99/EK irányelv].

126 2008/99/EK irányelv, Preambulum (10) bekezdés.

127 2008/99/ EK irányelv, 3. cikk, Büncselekmények f)-g) pontok: ,, védett, vadon élő állat- vagy növényfajok megölése, elpusztítása, birtoklása vagy begyüjtése, kivéve azokat az eseteket, amikor a cselekmény az érintett fajok példányainak elhanyagolható mennyiségét érinti, és elhanyagolható hatással jár a faj védettségi helyzetére nézve;

védett, vadon élö állat- vagy növényfajok példányaival, azok részeivel vagy származékaival való kereskedelem, kivéve azokat az eseteket, amikor a cselekmény az ilyen példányok elhanyagolható mennyiségét érinti, és elhanyagolható hatással jár a faj védettségi helyzetére nézve;"

${ }^{128}$ GÖRGÉNYI ILONA: A környezetvédelmi büntetöjog megújulása az új évezredben. Miskolci Jogi Szemle, 6. évf. 2001. különszám. 103-105. p.
} 


\section{III.3.2. A szervezett bünözés és a súlyos büncselekménynek minősítés}

A szervezett bünözői csoportok részvétele a környezet elleni büncselekményekben, különösen vadvilági kereskedelemben, nagy kihívás elé állítja a nemzeti hatóságokat. Tágabb értelemben a környezet elleni büncselekmények minden formája esetében megtalálható a szervezett bünözői elem, ahogyan az korábban, az egyes cselekményi formáknál már hangsúlyoztam. A szervezett bünözés természeténél fogva rejtett jellegü, így a döntéshozatal hagyományos formái gyakran gyengén alkalmazhatóak. A szervezett bünözés mutatószámai változatos formát öltenek, és sok esetben alkalmazkodnak a tevékenyég specifikus jellegéhez.

A vadvilággal kapcsolatos büntetendő cselekmények fogalmi kérdésinek vizsgálata során elengedhetetlen a határon átnyúló szervezett bűnözés definíciójának tisztázása. Önmagában a szervezett bünözés jellegzetességeiben egyetértés van, amellyel a legtöbb ilyen tevékenységet végző csoport rendelkezik. A szervezett bünözési tevékenységet végző csoportok célja önmagában nem különbözik a többi, piacon jelenlévő vállalkozásétól: meghatározott piaci részesedés fenntartása és egy meghatározott termék vagy szolgáltatás iránti kereslet biztosítása. A TOC nagyfokú szervezettséget igényel, amely párosul az erőszakra és korrupcióra való hajlandósággal. Amikor a szervezett bünözés a határok átlépésével és a más államokban való tevékenységgel nemzetközivé válik, a bűnözői csoportok ki tudják használni a gyakran társadalmilag és gazdaságilag meggyengült államok nehézségeit. ${ }^{129} \mathrm{~A}$ határon átnyúló bűnözés fogalma olyan cselekményekre utal, amikor az áru megszerzése, szállítása és elosztása nemzetközi határokon történik vagy annak közvetlen, illetve közvetett hatásai több mint egy országra terjednek ki. Ennek következtében a büncselekmények elleni fellépés is több államban kell, hogy megtörténjen, általában államok és/vagy nemzetközi bünüldöző szervek, nemzetközi szervezetek segítségével. ${ }^{130}$ A határon átnyúló szervezett bünözés tekinthető a jelenlegi évszázad egyik legnagyobb, az emberiséget fenyegető veszélynek. Emiatt számos nemzetközi szervezet, különösen az ENSZ, célzott és hatékonyan végrehajtott programok kidolgozására törekszik a TOC térnyerésének megállítására és a már létező szervezett bünözői csoportok felszámolására. ${ }^{131}$

\footnotetext{
129 A transznacionális szervezett bünözés jelentőségéről bővebben: In: The Globalisation of Crime. A Transnational Organised Crime Threat Assessment. UNODC, United Nations Publications, Bécs, 2010. 25-39. p.

${ }^{130}$ ECOSOC, Commission on Crime Prevention and Criminal Justice, Report on the 6th Session, 1997. E/CN.15/1997/21. International Cooperation in Combating Transnational Crime, 126-134. p.

${ }^{131}$ UN Press Release, GA/SHC/3529 1999. október 18.

Online elérhető: https://www.un.org/press/en/1999/19991019.gashc3531.doc.html.
} 
A TOC dinamikus növekedése összefügg a globalizációval és a korábbi, kétpólusú világrend felbomlásával is, amely lehetőséget adott, hogy a korábban a Nyugattól „pajzsként elzárt" szervezett bűnözői csoportok a határok megnyitásával kibővítsék hálózataikat. ${ }^{132}$ A TOC manapság nevezhető „globalizált illegális gazdaságnak” is, hiszen egyedül a 2009-es évben mintegy 870 millió USD-t termelt, ami a globális GDP 1,5 százaléka. Az elmúlt évtizedekben a szervezett bünözői csoportok jelentős mértékben növekedtek a nemzetközi színtéren való aktivitás mértékében. ${ }^{133}$

A határon átnyúló szervezett bünözés szakirodalmi fogalma általában három főbb elemet különböztet meg: a cselekmény folytonos jellegét, a korrupció gyakorlatát és az erőszakra való hajlamot. Más definíciók említést tesznek a következőkről is: nagyszámú személy részvétele; a bünelkövetés mint célkitűzés; határokon átívelő műveletek a tiltott termékek iránti keresletre való válaszként; a jelentős erőforrások megszerzésére és birtoklására való képesség, magas és gyors profitszerzés. A környezet elleni büncselekményeket elkövetö szervezett bünözői csoportok nagy része rendelkezik a fenti jellegzetességek többségével. Összességében az egyes fogalmak a TOC következö jellegzetességeit állapítják meg:

a) határokon átívelő jogellenes müveletekben való részvétel, gyakran az illegális termékek iránti keresetre való válaszként;

b) kormányzati hivatalnokok korrupcióban való részvételre biztatása, különösen a gazdaságilag meggyengült országok kihasználásával;

c) jelentős erőforrások birtoklása;

d) belső rendszabályok által irányított hierarchikus, merev vagy csoportokra osztott szervezeti felépítés, amely a szervezeti, adminisztratív és ideológiai funkciókat ellátó vezetőséget védelmezi;

e) fedőcégek és üzletek működtetése a jogellenes tevékenységből származó összegek tisztára mosása érdekében, pénzmosás;

f) tevékenységek széles körében való részvételi hajlandóság és a résztvevők profeszszionalizmusa;

g) elérhető legnagyobb profitszerzési cél a lehető legrövidebb idő alatt;

h) elhúzódó müveleti tevékenység;

\footnotetext{
${ }^{132}$ Boris Uvarov, Serious Crime Investigator, 1992.

Idézet forrása: STERLING, CLAIRE: Thieves' World: the threat of the global network of organised crime. Simon and Schuster, NY, 1994. 13. p.

${ }^{133}$ UNODC: Transnational organized crime: the globalized illegal economy. https://www.unodc.org/toc/en/crimes/organized-crime.html (2018.12.21.).
} 
i) nemzetközi műveletek szervezése több nemzetből származó személyekkel. ${ }^{134}$ Az egyre fenyegetőbb jelenség ellen az államok nemzetközi, regionális és helyi jogalkotással, programtervezéssel igyekeznek felvenni a küzdelmet. A nemzetközi egyezmények közül részletesen kiemelem az ENSZ Palermói Egyezményét. Azonban több egyezmény is kidolgozásra került a TOC-re való regálásként. ${ }^{135}$ A nemzetközi szervezett bünözés ellen az ENSZ keretében alkottak egyezményt, ${ }^{136}$ amelyet a Közgyülés 2000 . november 15-én fogadott el, 55/25. számú határozatával. Az egyezmény 2003 szeptemberében lépett hatályba, a negyvenedik megerősítő okmány beérkezését követően. Jelenleg 189 részes féllel rendelkezik, Magyarország a 2006. évi CI. törvénnyel hirdette ki.

Az egyezmény fő célja a súlyos büncselekmények megelőzése, felderítése, nyomozása és üldözése, amennyiben a büncselekmény nemzetközi jellegü és szervezett bünözői csoport vesz benne részt. ${ }^{137}$ A nemzetközi szervezett bünözés elleni egyezmény részletesen meghatározza az alkalmazásába tartozó büncselekményeket, ugyanakkor nem jelöli meg pontosan, mit jelent a nemzetközi szervezett bünözés mint fogalom. Továbbá, nem tartalmaz taxatív felsorolást az alkalmazási körébe eső büncselekmények tekintetében sem. A definíció hiánya akaratlagos döntés volt a szerződés szövegezésekor annak érdekében, hogy a bünözés újabb típusainak megjelenésekor, illetve a globális, regionális, valamint helyi

\footnotetext{
${ }^{134}$ GUYMON, CARRIELYN DONINGEN: International Legal Mechanisms for Combating Trans-national Organized Crime: The Need for a Multilateral Convention. Berkeley J. Int'L. 53. (2000) 73-85. p. [Továbbiakban: GUYMON, 2000.].

${ }^{135}$ Az ENSZ Drog Egyezménye [United Nations Convention against Illicit Traffic in Narcotic Drugs and Psychotropic Substances. Az Egyesült Nemzetek Szervezete keretében a kábítószerek és pszichotrop anyagok tiltott forgalmazása elleni, 1988. december 20-án, Bécsben kelt Egyezmény. UNTS 1582 (p.95) 1988. (1990.) Kihirdette: 1998. évi L. törvény.] az egyik legrégebben elfogadott instrumentum a szervezett bünözés ellen. Az Európa Tanács keretében külön egyezmény került elfogadásra a pénzmosás területén. [Council of Europe Convention on Laundering, Search, Seizure and Confiscation of the Proceeds from Crime and on the Financing of Terrorism. 2005 Council of Europe Treaty Series - No. 198 Sz Európa Tanács pénzmosásról, a büncselekményből származó jövedelmek felkutatásáról, lefoglalásáról és elkobzásáról, valamint a terrorizmus finanszírozásáról szóló, Varsóban, 2005. május 16-án kelt Egyezménye. Kihirdette: 2008. évi LXIII. törvény.] Az OECD 1997-ben fogadta el a külföldi hivatalos személyek megvesztegetése elleni küzdelemről szóló egyezményt, amelynek jelenleg 44 tagja van: az összes OECD tagállam és 8 egyéb (Argentína, Brazília, Bulgária, Columbia, Costa-Rica, Peru, Oroszország, Dél-Afrika)[OECD Convention on Combating Bribery of Foreign Public Officials in International Business Transactions. A külföldi hivatalos személyek megvesztegetése elleni küzdelemről szóló Egyezmény. 1997.(1999.) Kihirdette: 2000. évi XXXVII. törvény.].

A különböző regionális keretekben elfogadott megállapodások közül ki kell emelni az Európai Unió korrupció, pénzmosás és szervezett bünözés elleni szabályozását és programjait. Általános értelemben megállapítható, hogy a TOC elleni harc második rétegét - a globálisan elfogadott egyezmények mellett - a különböző regionális szervetek keretében elfogadott megállapodások biztosítják. Így az Amerikai Államok Szervezete által létrehozott „Drug Abuse Commission”, az Arab Liga keretében elfogadott számos szerződés és a karibi térség programjai. A következő szintet a kétoldalú megállapodások adják, amelyek lehetnek kiadatási szerződések, vagy kölcsönös jogi segítségnyújtási egyezmények.

${ }^{136}$ United Nations Convention against Transnational Organized Crime. A nemzetközi szervezett bünözésről szóló ENSZ egyezmény. UNTS, vol. 2225, 209. p. 2000. (2003.) Kihirdette: 2006. évi CI. törvény.

137 2006. évi CI. tv. 3. cikk (1) bekezdés b) pont.
} 
viszonyok megváltozása esetében is alkalmazható maradjon az egyezmény. Ennek értelmében a nemzetközi szervezett bünözés magában foglal minden nemzetközi vonatkozású, profitorientált súlyos bűncselekményt. ${ }^{138}$ Ezen túlmenően az egyezmény a nemzetközi szervezett bünözés egyes fogalmi elemeit egzaktan rögzíti. Súlyos büncselekmény a „legalább négy év szabadságvesztéssel vagy súlyosabb büntetéssel büntethetö büncselekményt megvalósitó magatartás". Nemzetközi jellegünek tekinthető a büncselekmény, ha nemzetközi jellegü, vagyis azt több mint egy államban követik el; illetve azt egy államban követik el, de előkészítésének, tervezésének, irányításának és ellenőrzésének jelentős részét egy másik államban végzik. Ugyancsak nemzetközinek minősül, ha bár a büncselekményt egy államban követik el, de olyan szervezett bünözői csoport vesz benne részt, amely egynél több államban folytat bűnöző tevékenységeket. Illetve, az egyezmény meghatároz egy utolsó fordulatot is, így nemzetközinek minősül a büncselekmény, ha azt egy államban követik el, de jelentős hatással van egy másik államra nézve. ${ }^{139}$ A szervezett bünözői csoport fogalmát is meghatározza, így az „egy bizonyos ideig fennálló, három vagy több föböl álló strukturált csoport, amely összehangoltan müködik egy vagy több, a jelen Egyezményben meghatározott súlyos büncselekmény elkövetése céljából, közvetlen vagy közvetett módon pénzügyi vagy más anyagi haszon megszerzésére törekedve."140

A nemzetközi szervezett bünözésről szóló egyezményhez három kiegészítő jegyzőkönyv került elfogadásra, amelyek közül az első az emberkereskedelemmel (különös tekintettel a nőkre és gyermekekre), ${ }^{141}$ a második a bevándorlók földön, tengeren és levegőben történő csempészetével, ${ }^{142}$ a harmadik pedig az illegális fegyver-előállítással és fegyverkereskedelemmel ${ }^{143}$ kapcsolatos.

\footnotetext{
${ }^{138}$ Transnational Organized Crime https://www.unodc.org/ropan/en/organized-crime.html (2018. 05. 24.) 139 2006. évi CI. tv. 3. cikk (2) bekezdés.

140 2006. évi CI. tv. 2. cikk a) pont.

${ }^{141}$ Protocol to Prevent, Suppress and Punish Trafficking in Persons, Especially Women and Children, supplementing the United Nations Convention against Transnational Organized Crime. Az ENSZ nemzetközi szervezett bünözés elleni egyezményének (Palermói Egyezmény) az emberkereskedelem, különösen a nők és gyermekek kereskedelme megelőzéséről, visszaszorításáról és büntetéséről szóló Jegyzőkönyve. Kihirdette: 2006. évi CII. törvény.

${ }^{142}$ Protocol against the Smuggling of Migrants by Land, Sea and Air, supplementing the United Nations Convention against Transnational Organized Crime. Az Egyesült Nemzetek keretében, Palermóban, 2000. december 14-én létrejött, a nemzetközi szervezett bünözés elleni Egyezménynek a migránsok szárazföldön, légi úton és tengeren történő csempészete elleni fellépésről szóló Jegyzőkönyve. Kihirdette: 2006. évi CIII. tv.

${ }^{143}$ Protocol against the Illicit Manufacturing of and Trafficking in Firearms, Their parts and Components and Ammunition, supplementing the United Nations Convention against Transnational Organized Crime. Az Egyesült Nemzetek keretében létrejött, a nemzetközi szervezett bünözés elleni egyezményt kiegészítö, a tüzfegyverek, részeik, alkotóelemeik és lőszereik tiltott előállítása és kereskedelme elleni jegyzőkönyve.
} 
Természetesen, a TOC elleni küzdelem elképzelhetetlen állami szabályozás nélkül, amelynek meg kell valósítania a nemzetközi szinten - általában szerződések keretében vállalt kötelezettségeket és hatékony végrehajtási intézkedéseket kell bevezetnie.

A határon átnyúló szervezett bünözés már régóta foglalkoztatja a kriminológusokat. A legutóbbi kutatások azonban a szervezett bünözés új területeire is irányulnak, így a természeti erőforrásokkal és vadvilági termékekkel folytatott kereskedelmi tevékenységre. Eddig a veszélyeztetett vadvilági termékek fekete piaci kereskedelme csupán kis figyelmet kapott, annak ellenére, hogy éves szinten mintegy 6 milliárd dolláros forgalomról beszélhetünk. ${ }^{144}$ A szervezett bünözés és a vadvilággal kapcsolatos büncselekmények, az illegális vadvilági kereskedelem olyan területek, amelyek egyre inkább a nemzetközi érdeklődés középpontjába kerülnek. A vadvilággal kapcsolatos büncselekmények önmagában is fenyegető hatással bírnak az egyes államok gazdaságára, jövőbeli fejlesztési lehetőségeire és biztonságára nézve. Azonban az elmúlt egy-két évtizedben a szervezett bünözői csoportok felfigyeltek a természeti erőforrások kiaknázásában rejlő lehetőségekre, így elősegítve a TOC és a környezet elleni büncselekmények összefonódását.

A következőkben röviden összefoglalom, hogy véleményem szerint a vadvilággal kapcsolatos büntetendő cselekmények köre milyen kihívások elé állítja az államokat és különösen azok vám- és végrehajtó szervezetrendszerét:

a) a természeti erőforrások kiaknázása jelentős állami bevételt jelent. Például egyes fejlődő államok ásványkincsekben, nemesfémekben gazdagok, de az illegális bányászat miatt azok nem az ország fejlesztési programjainak megvalósítására kerülnek felhasználásra;

b) a vám- és végrehajtó szervek egyes tagjai hajlandók korrupcióra, így a jogi normák nem kerülnek végrehajtásra, kikényszerítésre, ezért a jogellenes kereskedelem tényleges volta is nehezen becsülhető meg;

c) a jogellenes kiaknázás és a természeti erőforrások pazarlása lehetetlenné teszi a jövőbeli fejlesztési lehetőségek megvalósítását;

d) a biodiverzitás csökkenése már megállíthatatlannak tünik, a fajok jelentős része néz szembe a végleges kihalás lehetőségével;

e) a jogszerü kereskedelem ernyője alá bújtatott illegális kereskedelem rejtetten marad.

\footnotetext{
${ }^{144}$ WARChOl, GREG L.ZUPAN, LINDA L.CLACK, WILLIE: Transnational Criminality: an analysis of the illegal wildlife market in Southern Africa. International Criminal Justice Review. Volume 13. 2003. 1. p. [Továbbiakban: WARCHOL-ZUPAN-CLACK 2003.].
} 
Azonban a TOC beszivárgásával további kockázatok is megjelentek az államok számára, így a vadvilági bünözés által támasztott negatív hatások mellett:

a) a szervezett bünözői csoportok további, az ország biztonságára nézve veszélyes tevékenységek finanszírozására használják fel a vadvilággal kapcsolatos bűncselekményekböl nyert hasznot;

b) a szervezett bünözői csoportok olyan kialakult hálózatokkal rendelkeznek, amelyek könnyen lehetővé teszik a vadvilágból származó egyedek vagy termékek csempészetét, kontinensek közötti szállítását;

c) a haszon egyes esetekben kifejezetten terrorcselekmények finanszírozása érdekében kerül felhasználásra;

d) a szervezett bünözői csoportok segítségével olyan orvvadászok pusztítják el az egyedeket, akik sok esetben jobb fegyverekkel és erőforrásokkal rendelkeznek, mint maguk az állami fegyveres szervek. Ezáltal számos esetben halálos áldozatokat is követelő tüzharc alakul ki az orvvadászok és az állatokat, területeket védő rendvédelmi szervek között;

e) egyre gyakoribb az olyan csempészeti tevékenység, amely együtt jár az egyes jogellenes termékek - fegyver, drog - és a vadvilági egyedek, termékek kevert szállításával. Így nagyon nehéz megbecsülni az egyes tevékenységek valódi mértékét.

Összességében elmondható, hogy a vadvilággal kapcsolatos büncselekmények olyan kihívás elé állítják a nemzetközi közösséget, amely kizárólag az államok, állami szervek, nemzetközi szervezetek és a privát szektor együttmüködésével oldható meg. Megállapítható, hogy a TOC a globális biztonság egyik legnagyobb fenyegetője, valamint jelentős társadalmi és gazdasági károkat okoz. A TOC elleni küzdelem keretében számos nemzetközi szerződés és program került kidolgozásra, azonban a szervezett bűnözés nagyban profitál a különböző jogszabályozási hiányokból és a végrehajtási szervezetrendszer nehézségeiből. Erre hívja fel a figyelmet az Európa Tanács által 2014-ben kiadott nemzetközi szervezett bűnözésről szóló Fehér Könyv is. ${ }^{145}$ A vizsgálódás főbb következtetései között szerepel, hogy jelenleg nincsen szükség további egyezményalkotásra a TOC körében, hiszen elegendő jogi norma áll rendelkezésre. A probléma a hiányos végrehajtásban keresendő. ${ }^{146}$ További nehézségek adódnak abból, hogy az Európa Tanács keretében

\footnotetext{
${ }^{145}$ White Paper on transnatinal Organised Crime. CDPC (2014) 11 Strabourg, 2014. május 28. [Továbbiakban: White Paper].

146 White Paper ii) pont.
} 
elfogadott egyezmények aláírásra kerülnek az államok részéről, azonban a ratifikáció elmarad és számos, korábban tett fenntartás idejétmúlttá vált az évek során. A nemzetközi szerződésekből eredő kötelezettségek végrehajtása során az államok nagyon eltérő utakat követnek, különösen a büntetőjog és bünügyi együttműködés területén, amely nagyban megnehezíti az érintett területeken való együttmüködést is. ${ }^{147}$

A vadvilággal kapcsolatos büntetendő cselekményekből származó illegális jövedelem világszinten a harmadik helyet foglalja el, azonban sem a szervezett bünözésről szóló egyezmény, sem az ahhoz kapcsolódóan elfogadott kiegészítő jegyzőkönyvek nem említik azt. Ennek a jogalkotási, végrehajtási és igazságszolgáltatási rendszerben fellelhető hiányosságnak a leküzdésére törekszenek az olyan nemzetközi szervezetek, mint a UNODC. A TOC és a vadvilággal kapcsolatos büncselekmények közötti szoros kapcsolatra már több nemzetközi szervezet is felhívta a figyelmet, azonban csupán 2016-ban készült el az első olyan riport, amely részletesen foglalkozik a vadvilággal kapcsolatos büncselekményekkel mint szervezett bünözési formával, és részletesen feltárja a két jelenség közötti kapcsolódási pontokat. Így elmondható, hogy nemzetközi színtéren is elterjedni látszik az a felfogás, amely a vadvilággal kapcsolatos büncselekményekhez a nemzetközi szervezett bűnözésen keresztül közelít. ${ }^{148}$

\footnotetext{
${ }^{147}$ White Paper 18. p.

148 Wildlife crime assessed globally for the first time in new UNODC report. https://www.unodc.org/unodc/en/frontpage/2016/May/wildlife-crime-assessed-globally-for-the-first-timein-new-unodc-report.html (2018. 10. 23.).

Jelentés elérhető: World Wildlife Crime Report, 2016. https://www.unodc.org/documents/data-and-analysis/wildlife/World_Wildlife_Crime_Report_2016_final.pdf.
} 


\section{III.3.3. A korrupció}

A korrupció fogalma köznapi értelemben viszonylag egyszerüen megragadható: „a közhatalommal, közbizalommal, ráruházott pozícióval való visszaélés egyéni haszonszerzés érdekében.” Természetesen, a korrupciónak is több formája, szintje létezik: megvalósulhat magas szintű kormányzati körökben, a közjavakból való egyéni profitszerzés érdekében, a középszintü- vagy helyi vezetés által, akikhez általában a lakosok fordulnak, bizonyos előnyök szerzése érdekében. ${ }^{149}$ A környezeti büncselekmények esetében a korrupció biztosítja a szabályok megkerülését, a ,félrenézést", ami lehetővé teszi az erőforrások kiaknázását, azok kereskedelmét-szállítását és végül eladását, profitszerzés érdekében. A vadvilággal kapcsolatos büntetendő cselekmények megvalósulásához gyakorlatilag elengedhetetlen feltételként társulnak a korrupciós cselekmények. A korrupció tehát szorosan kapcsolódik a környezeti büncselekményekhez, különösen a vadvilággal kapcsolatos büntetendő cselekmények köréhez, az illegális kereskedelmi tevékenységhez. Ahogyan már arra korábban történt utalás, a kínálati oldal, vagyis a vadvilágból származó egyedek és termékek származási országai általában fejlődő államok. Utóbbiakra jellemző a nem megfelelő gazdasági teljesítmény, a gyenge kormányzati struktúra, sebezhetővé téve őket a korrupcióra. Tudományos szinten kimutatásra került, hogy a jogellenes elefántcsontkereskedelem és az állami korrupció között világos összefüggés van, lehetővé téve az orrvadászatot és az elefántcsont nemzetközi határokon történő átjuttatását, akár diplomáciai álca alatt vagy vesztegetés, hamis iratok használatával. ${ }^{150}$ A korrupció aláássa a környezeti kormányzást, a fajmegőrzési kísérletek sikeres teljesítését. A korrupció egyes államokban a legmagasabb szintekre is begyürüzött, így a katonaság, a rendőrség, a határvédelmi szervezetek kötelékeibe, az igazságszolgáltatásba, vámhatóságokhoz, a követségi alkalmazottak és az állami diplomaták körébe, akik mind aktívan közremüködnek a jogellenes kereskedelem lehetővé tételében. ${ }^{151}$ Kimutatásra került, hogy azok az államok,

\footnotetext{
149 Transparency International, How do you define corruption? https://www.transparency.org/what-is-corruption\#define (2019. 08. 04.).

${ }^{150}$ A korrupció és a jogellenes elefántcsontkereskedelem közötti összefüggésre mutat rá a következő feltáró tudományos kutatás: LEMIEUX, ANDREW M. - CLARKE, RONALD V.: The International Ban on Ivory Sales and its Effects on the Elephant Poaching in Africa. Brit. J. Criminol. Vol. 49. 2009. 451-471. p.

${ }^{151}$ A katonai szervezet korrupciója mutatkozik meg számos afrikai államban.

See Jeffrey Gettleman: Elephants Dying in Epic Frenzy as Ivory Fuels War and Profits. NY Times, 2012. szeptember 03. https://www.nytimes.com/2012/09/04/world/africa/africas-elephants-are-being-slaughtered-in-poaching-frenzy.html (2019. 08. 04.).

Több országra kiterjedően vizsgálták a jogellenes tevékenységekben részt vevők körét: VAN UHM, DAAN P. - Moreto, William: Corruption Within the Illegal Wildlife Trade: A Symbiotic and Antithetical Enterprise. Brit. J. Criminol. Vol. 58. 2018. 864-885. p. [Továbbiakban: VAN UMH, MORETO 2018.].
} 
ahol a biológiai sokféleség különösen gazdag, ki vannak téve az ún. „eröforrás átoknak", ${ }^{152}$ vagyis a természeti erőforrások magas szintje ellenére alacsony szintű fejlettséggel rendelkeznek és jobban ki vannak téve a korrupciónak. ${ }^{153}$

Ugyanakkor világosan kell látni, hogy a korrupció és az annak minősülő jelenségek léte összetett háttérokok miatt alakulnak ki a gazdaságilag kevésbé fejlett, bár erőforrásgazdag államokban. Például Malajziában, a Föld egyik „,biodiverzitás forrópontjában” feltáró kutatást készítettek arról, milyen okok vezetnek a korrupcióhoz és így a vadvilággal kapcsolatos büncselekményekhez. A helyi lakosokkal készült interjúkból kiderül, hogy több tényező áll a szabályok megkerülése vagy a konkrét korrupciós cselekmények elkövetése mögött: a korrupcióra való érzékenység; az alternatív normák léte (pl. szokások, társadalmi standardok); a jogi szabályozás hiányos ismerete; az igazságosság kérdése és a szegénység. A felsoroltak közül leginkább az igazságossággal kapcsolatos felvetések voltak szembetünők, több szinten is. A helyi közösségek a természetvédelmi szabályokat igazságtalannak tartják, mivel azok álláspontjuk szerint a gazdag embereket védik, akik „érinthetetlenek”, ellentétben a szegényekkel, akik súlyos jogkövetkezményekre számíthatnak. Másrészről, sokan úgy vélik, ha a természetvédelmi törekvések és egyes fajok, például a lemurok védelme kiemelt érdeknek számítanak, akkor miért nem törődnek az emberekkel, a helyi közösségek jólétével? ${ }^{154}$

A korrupció elleni harc és fellépés nagy kihívás elé állítja a nemzetközi közösséget természetvédelmi célok megvalósításában. A fellépés mindenképpen több szinten kell, hogy történjék, elsősorban a társadalmi igazságosság fejlesztése terén, amely lehetővé teszi a helyi közösségek „érzékenyítését” a korrupciós cselekmények iránt. Azonban a jog eszköztárást sem szabad elvetni, így az egyik legfontosabb célkitüzés lett, hogy a releváns nemzetközi jogi instrumentum minél szélesebb körü támogatást nyerjen el az államok részéröl.

A 2003-ban aláírt és 2005-ben hatályba lépett korrupció elleni egyezmény ${ }^{155}$ az egyik legfontosabb eszköz lehet a vadvilággal kapcsolatos büncselekmények visszaszorítása érdekében. A vadvilággal kapcsolatos büncselekmények és a korrupció közötti összefüggés

\footnotetext{
152 Angol nyelvü terminológiában: „Resource curse”.

See The Resource Curse. The Political and Economic Challenges of Nature Resource Wealth. Nature Resource Governance Institute, 2016. 1-6. p. https://resourcegovernance.org/sites/default/files/nrgi_ResourceCurse.pdf.

153 VAN UMH, MORETO 2018. 865. p.

${ }^{154}$ L. GORE, MEREDITH - RATSIMBAZAFY, JONAH; L. LUTE, MiCHELlE: Rethinking Corruption in Conservation Crime: Insights from Madagascar. Conservation Letters 6:6 2013. nov./dec. 434-435. p.

${ }^{155}$ United Nations Convention against Corruption. Az Egyesült Nemzetek korrupció elleni egyezménye. 2003. (2005.) Magyarországon kihirdette: 2005. évi CXXXIV. törvény
} 
vitathatatlan, mint ahogyan arra az ENSZ korrupció elleni egyezményének 7. részes felek találkozóján ${ }^{156}$ is rámutattak.

A korrupció segíti a transznacionális szervezett bünözést és mindennapos az illegális vadvilági kereskedelem során, azért mind a CITES-ben, mind a UNCAC-ban részes államokat az egyezmények minél hatékonyabb végrehajtására szólították fel. A korrupció a vadvilág, az erdészet és a halászat minden szegmensében előfordulhat. Magában foglalhatja az információért való megvesztegetést, jogok vagy kvóták megszerzését, az ügyintézés és szállítmányok meggyorsítását, az ellenőrzés vagy mérés elkerülésének biztosítását. Az Egyezmény gyakorlatban történő megvalósulását nagy mértékben hátráltatja a CITESben részes államok rendészeti, vám- és egyéb végrehajtó vagy akár igazságszolgáltató szervezeteinek korrupcióra való hajlandósága, amely az ellenőrzés elmaradását biztosító „szemet hunyástól” a dokumentáció hamisításáig és az orvvadászok szabadon engedéséig is terjedhet. ${ }^{157}$

A korrupció jelentőségét felismerve a CITES 17. részes felek konferenciáján, Johannesburgban elfogadták az első, korrupcióval foglalkozó határozatot. ${ }^{158}$ A dokumentumban elismerik, hogy a szervezett bűnözői csoportok és hálózatok magas részévétele az Egyezmény megsértésében gyakran korrupciós technikák alkalmazásában mutatkozik meg. A Közgyülés 69/80-as határozatában felhívta a tagállamokat, hogy akadályozzák és előzzék meg az illegális vadvilági kereskedelem érdekében kifejtett korrupciós tevékenységeket. A CITES határozat arra is rámutat, hogy az UNCAC fontos eszköz a korrupció elleni harcban, ugyanakkor számos CITES tagállam nem részes fél abban. Éppen ezért felszólították a Washingtoni Egyezményben részes államokat az UNCAC ratifikálására. ${ }^{159}$ Jelenleg 186 részes féllel megállapítható, hogy az elsődleges célkitüzés, vagyis az UNCAC széles körü támogatottsága elérésre került, a jövőben emiatt az egyezmény hatékony állami végrehajtása és a nemzeti szintű programok kidolgozása lesz majd prioritás. ${ }^{160}$

\footnotetext{
${ }^{156} 7$ th session of the Conference of the States Parties to the United Nations Convention against Corruption (UNCAC CoSP7, Bécs, 2017. november 6-10.).

157 Links between corruption and wildlife crime highlighted at UN anti-corruption conference. https://www.unodc.org/unodc/en/press/releases/2017/November/links-between-corruption-and-wildlifecrime-highlighted-at-un-anti-corruption-conference.html (2019. 02. 17.).

${ }^{158}$ Res. Conf. 17.6 Prohibiting, preventing, detecting and countering corruption, which facilitates activities cnducted in violation of the Convention [Továbbiakban: Res. Conf. 17.6].

${ }^{159}$ Res. Conf. 17.6 Preambulum és 3-4. pontok.

${ }^{160}$ Signature and Ratification Status

https://www.unodc.org/unodc/en/corruption/ratification-status.html (2019. 08. 04.).
} 


\section{III.4. A vadvilággal kapcsolatos büncselekmények jellemzői}

Az alábbi ábra a vadvilággal kapcsolatos büncselekmények és az egyes fogalmi elemek, jellemzők közötti összefüggéseket szemlélteti. ${ }^{161}$

\section{1. ábra Összefüggések bemutatása}

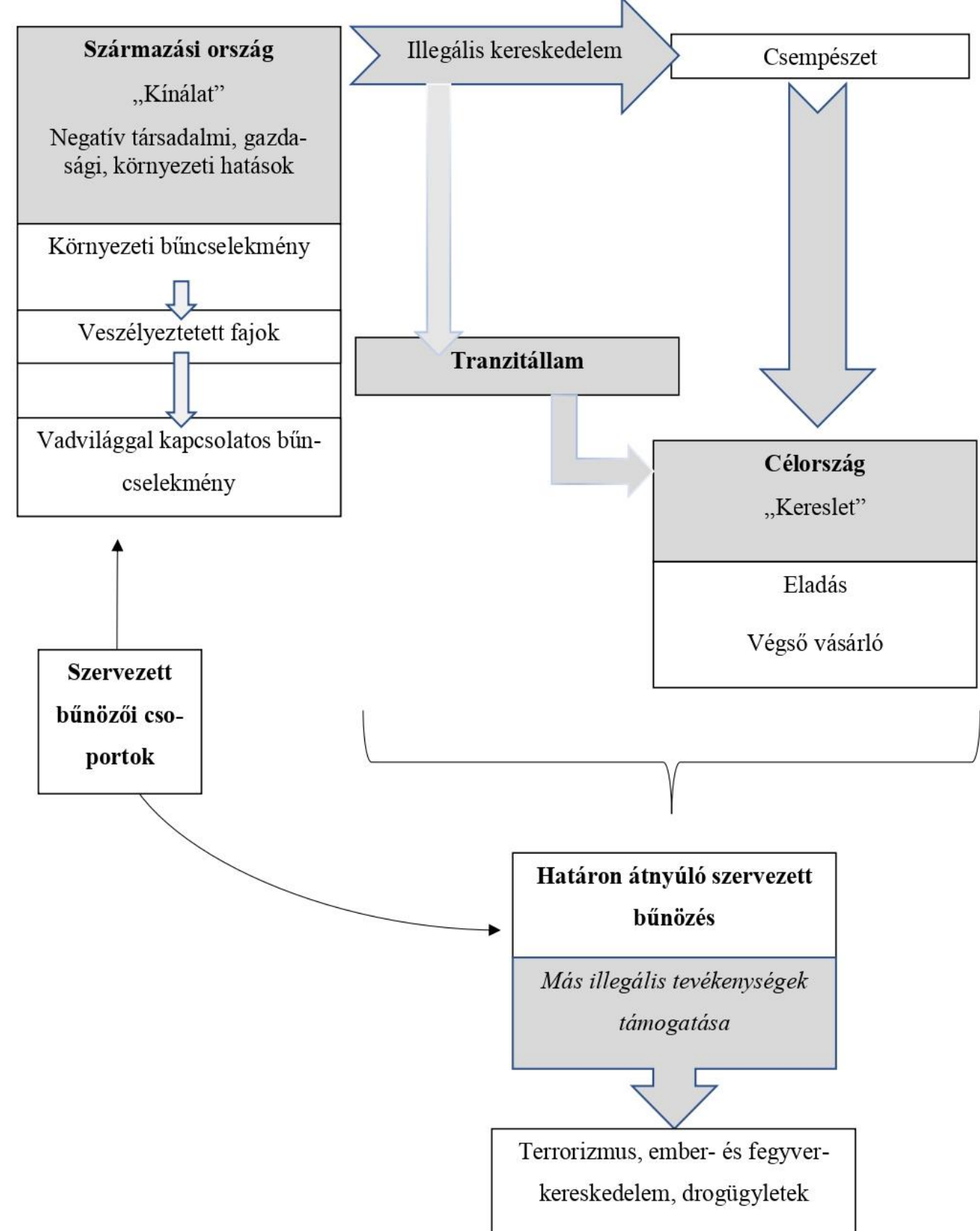

161 1. ábra: szerző saját munkája, szerkesztése. 
A környezet elleni büncselekmények egyik megvalósulási formája a vadvilággal kapcsolatos büncselekmények köre, ezen belül pedig a vadon élö állat- és növényfajokkal, valamint az azokból készült termékekkel folytatott kereskedelem. A vadvilággal kapcsolatos büncselekményeknél tágabb kört fog át a büntetendő cselekmények köre, hiszen csak a legsúlyosabb elkövetési magatartásokat sújtják olyan büntetőjogi jogkövetkezményekkel, mint a szabadságvesztés. Az értekezés alapját az előzőekben ismertetett cselekményi körből egy, a vadvilági kereskedelem képezi, ezen belül is a CITES keretében szabályozott, veszélyeztetett vadon élő fajokkal folytatott kereskedelmi tevékenység.

A környezet elleni büncselekmények esetében nem beszélhetünk egységes, nemzetközi szinten meghatározott fogalomról, így a nemzeti büntetőjognak nagy szerepe van. Bár a környezet büntetőjogi védelme nem idegen a nemzetközi normaalkotástól, annak legteljesebb formájában az Európai Unióban találkozhatunk. A környezet elleni büncselekmények változatos jogkövetkezményeket vonnak maguk után, amelyek a közigazgatási, a polgári- és a büntetőjog területére esnek.

A környezet elleni és így a vadvilággal kapcsolatos büncselekmény már nemzeti szinten, egy államon belül megvalósul, azonban az jellemzően nemzetközi, határon átnyúló jelleggel rendelkezik. Az elmúlt évtizedekben a szervezett bünözői csoportok felfigyeltek a vadvilágot károsító cselekményekben rejlő haszonszerzési lehetőségekre, így az illegális kereskedelmi tevékenység az érintett csoportok egyik fó bevételi forrása lett. Mindez azonban nem valósulhatna meg, ha a jelenlegi nemzetközi és nemzeti szabályozás hatékony megvalósítására kerülne sor. Továbbá, a probléma következő forrását jelenti a széles körben elterjedt korrupció, amely segítséget nyújt a szervezett bünözői csoportok tevékenységéhez és növeli a látenciát. A szervezett bünözői csoportok az így megszerzett hasznot sokszor más jogellenes tevékenységek finanszírozására használják fel, mint a terrorizmus, az ember- és fegyverkereskedelem, valamint a drogügyletek.

A veszélyeztetett fajok beszerzési, származási országa legtöbb esetben a fejlődő országok területe, ahol eleve kevesebb erőforrás áll rendelkezésre a vonatkozó rendészeti, igazságszolgáltatási szervezetrendszer fenntartására. A vadvilággal kapcsolatos büncselekmények negatív társadalmi, környezeti és gazdasági hatásokkal járnak, csökkentik az állami bevételeket és a fenntartható fejlődés útjában állnak. A jogellenesen megszerzett vadvilágból származó egyedeket és termékeket csempészútvonalakon és tranzitállamokon keresztül juttatják el a célországokba, leginkább a fejlett világ államaiba, mint Kína, az Európai Unió területe és az Amerikai Egyesült Államok. 
A vadvilágot károsító büncselekmények, amelyek a veszélyeztetett fajokat is érintik, elméleti jellegüknél fogva nem különböznek egyetlen más büncselekménytől sem. Azonban a környezet elleni büncselekményeket általában véve jellemzi, hogy nem állnak az érdeklődés központjában, azokat áldozat nélküli vagy kevésbé veszélyes cselekményeknek tekintik. Az elmúlt évtized azonban rámutatott, hogy a biológiai sokféleség megőrzése érdekében folytatott nemzetközi és állami erőfeszítések egyik legnagyobb gátja az elharapódzó jogellenes kereskedelmi tevékenység. Utóbbi felismerés alapozta meg azt a nemzetközi összefogást, amelynek ma már szemtanúi lehetünk. Mégis, mire a nemzetközi közösség eljutott egyáltalán a kereskedelmi tevékenység szabályozásához, olyan mértékü kizsákmányolás vette kezdetét, amely szinte megállíthatatlannak tünik.

A vadvilággal kapcsolatos büncselekmények jellemzői: a nemzetközi jelleg, a szervezett bünözői csoportok részvétele, a látencia és a korrupció kihasználása, az arra való hajlandóság. Utóbbiak nagyban megnehezítik azon természetvédelmi erőfeszítések végrehajtását, amelyek a fajok fennmaradásának biztosítását szolgálják. A vadvilággal kapcsolatos büncselekmények felszámolása vagy legalábbis megfékezése a XXI. század egyik legfontosabb kihívásának tekinthető. Azonban a téma összetettsége és az egymásnak feszülő - sokszor állami - érdekek azt az érzetet keltik, hogy még jelen körülmények között sem beszélhetünk egységes fellépésről. Ezen még az sem változtat, hogy a CITES lassan univerzális tagsággal rendelkezik.

A vadvilági kereskedelem nemzetközi szabályozása, a veszélyeztetett fajok védelme, a CITES végrehajtása olyan nemzetközi közjogi problémákat vet fel, amelyek megválaszolása nélkül aligha vezetnek majd eredményre biológiai sokféleség megőrzésére tett eröfeszítések. A jog mindig is kissé lemaradásban van a társadalomban megjelenő magatartásokhoz, jelenségekhez képest, hiszen a jogszabály-alkotást egyfajta „utánkövetés” jellemzi. A vizsgált területen sincs ez másképp és egyáltalán kérdés, további, új multilaterális környezeti egyezmények alkotása mennyiben befolyásolná a már kialakult környezeti problémák megoldását. Egyre inkább terjed az a nézet, hogy nincs szükség további jogalkotásra, hanem a már meglévő instrumentumok hatékony megvalósítására, végrehajtására kellene törekedni. Az értekezés további fejezeteiben a vadvilági kereskedelem kérdését elemzem, a nemzetközi közjog és az uniós jog szemszögéből, amely csupán egyetlen szegmens a környezet elleni bűncselekmények hosszú sorából. 


\section{A vadvilági kereskedelem}

A vadvilággal kapcsolatos büntetendő cselekmények egyik formája a jogellenes vadvilági kereskedelem, amely több szempontból is kiemelkedik a környezetet károsító cselekmények közül. Amíg a többi büncselekmény - mint az illegális kitermelés, orvvadászat megmaradnak egy adott állam területén, az illegális kereskedelem biztosítja, hogy a vadvilágból származó termékek vagy élő egyedek eljussanak akár más kontinensekre is. Továbbá, a kereskedelem lehet jogszerü is, amely szabályozására egy nemzetközi egyezmény, a CITES is elfogadásra került, amely immáron szinte a teljes nemzetközi közösség támogatását elnyerte. Azonban a vadvilággal kapcsolatos büntetendő cselekmények egyes aspektusai, mint a korrupció, a szervezett bünözés és a hatékony büntetőjogi eszközök alkalmazásának hiánya, akadályozzák a Washingtoni Egyezmény hatékony végrehajtását. A vadvilággal kapcsolatos büntetendő cselekmények előző fejezetben kialakított fogalmi eleminek és jellemzőinek logikai sorrendjét követve - a CITES-hez kapcsolódó jogi problémák feltárása előtt - elemzem a vadvilági kereskedelem legfontosabb aspektusait.

Elsősorban meg kell határozni a vizsgálat fókuszát. Vadvilági kereskedelemről akkor beszélünk, ha a gazdasági tevékenység tárgya valamely, a vadvilágból származó élő egyed, annak származéka, része vagy abból készült termék. A kereskedelmi tevékenység megvalósulhat egy államon belül is, azonban jelen esetben mindenképpen szükséges a transznacionális, vagyis a határon átlépő jelleg. A vadvilággal kapcsolatos kereskedelmi tevékenység akkor kerül különös szabályozás alá, ha az védett, vadon élö fajokat érint. Az előbbiekre tekintettel mind a nemzetközi szabályozás, mind a kihívások és az elemzés szempontjából is, vadvilági kereskedelem alatt a határon átlépö, védett, vadon élö állatés növényfajokkal történö gazdasági tevékenységet kell érteni.

A védett, vadon élő fajok kereskedelmének szabályozására került elfogadásra a CITES, amely 1973 óta az egyik legfontosabb multilaterális környezeti tárgyú egyezmény lett. Az utóbbi évtizedben jelentősége megmutatkozott a vadvilággal kapcsolatos büntetendő cselekmények kapcsán is, így feltétlenül meg kell vizsgálni, hogy a Washingtoni Egyezmény milyen kapcsolódási pontokkal rendelkezik a vizsgált tárgykörhöz. A CITES azonban explicit módon nem határozza meg a vonatkozó bűncselekmények fogalmát. Általában véve elmondható, hogy az olyan negatív jelenségek, mint a biológiai sokféleség csökkenése, a fokozott fajkihalás és a vadvilág kereskedelmi célú kizsákmányolása elleni 
küzdelem kizárólag nemzetközi összefogás eredményeképpen orvosolhatók. Ez a felismerés a CITES keretein túl is programalkotásra sarkallta az államokat. Ennek eredménye a 2010-ben létrehozott ICCWC, amelynek elsődleges feladata a koordináció, valamint a vadvilágot és az erdőket pusztító büncselekmények elleni minden irányú határozott fellépés. A konzorcium tevékenységében a CITES Titkárság, az INTERPOL,${ }^{162}$ az ENSZ Kábítószer- és Bűnügyi Hivatala, ${ }^{163}$ a Világbank és a Vámügyi Világszervezet vesznek részt. ${ }^{164}$ A CITES a vadvilággal kapcsolatos bűncselekményekre vonatkozó kommunikációjában felhívja a figyelmet arra, hogy a cselekmény még nem került be az úgynevezett legfőbb, nemzetközi szinten elkövetett büncselekmények közé, azonban nagymértékben rendelkeznek a szervezett bünözés jellemzőivel. A konzorcium álláspontjában a vadvilághoz tartozik a teljes fauna és flóra, vagyis állat- és növényvilág, annak minden egyede és magába foglalja az erdészeti és nem erdészeti használatú fafajokat is. Ezentúl, büncselekmény a természetes erőforrások védelme, kezelése és használata érdekében hozott nemzeti jogi szabályozás és egyéb rendelkezések megsértésével elkövetett minden tett. Így az ICCWC meghatározása szerint a vadvilágot közvetlenül kizsákmányoló tettek, mint az illegális fakitermelés vagy orvvadászat, valamint az alapcselekményt követő, feldolgozásból eredő cselekmények is a fogalomba tartoznak. Az előbbi kiegészül a jogellenes cselekmények eredményeként megszerzett haszon eltitkolásából és a pénzmosásból eredő büncselekményekkel. ${ }^{165}$

A nemzetközi szabályozás egyértelmüen azon fajokra koncentrál, amelyek érintettek a vadvilági kereskedelemben és veszélyeztetettnek minősülnek, vagy ha nem kerülne sor a kereskedelem szabályozására, annak mérteke negatív hatással lenne a faj fennmaradásának esélyére. Köznapi értelemben a vadvilági kereskedelem fogalma alá tartozik minden olyan kereskedelmi tevékenység, amely a vadvilágból származó állat-vagy növényfaj egyedét érinti, és az haszonszerzési vagy egyéb célzatból történik. ${ }^{166}$ Az Egyezmény részletesen meghatározza, mit tekint a vadvilági kereskedelem fogalma alá tartozónak, valamint fontos kiemelni, hogy a CITES a veszélyeztetett fajokra koncentrál. Kereskedelem „exportot, re-exportot, importot és tengerröl való behozatalt jelent”. ${ }^{167}$ Az egyedek tekintetében a faj „bármely fajt, alfajt vagy ezek földrajzilag elkülönült populációját

\footnotetext{
162 INTERPOL: Nemzetközi Rendőrségi Szervezet.

163 UNODC: United Nations Office on Drugs and Crime.

${ }^{164}$ ICCWC https://www.cites.org/eng/prog/iccwc.php (2019. 03. 29.).

${ }^{165}$ Wildlife crime https://cites.org/prog/iccwc.php/Wildlife-Crime (2019. 03. 29.).

${ }^{166}$ Fogalom: szerző saját megfogalmazása.

${ }^{167}$ CITES I. cikk c) pont.
} 
jelenti”, a példány pedig „bármely állatot vagy növényt, akár élő, akár élettelen állapotban", az egyes Függelékek tekintetében specifikálva. ${ }^{168}$

A kereskedelemhez kötődő büncselekmények egyik legújabb formája lett az online kereskedelem és önálló formája az ún. vadvilággal kapcsolatos kiberbüncselekmény. ${ }^{169} \mathrm{Az}$ internet globális összeköttetése, az eladók relatív névtelenségével párosulva és segítve a gyors szállítással, lehetőséget biztosít, hogy a vadvilági kereskedelmet folytatók vadvilági termékeket adjanak el, vásároljanak és küldjenek egy közvetlen, online tranzakció keretében. Az IFAW ${ }^{170} 2004$ óta vizsgálódik a védett és veszélyeztetett fajok online kereskedelme témakörében. Az online vadvilági kereskedelem ellenőrzése nem valósulhat meg globális összefogás nélkül, amely magában foglalja a civil, kormányzati és végrehajtó szektorok együttműködését is. 2018 márciusában három szervezet, az IFAW, a WWF és a TRAFFIC útjára indította az online vadvilági kereskedelem megszüntetése érdekében létrehozott koalíciót, 21 vállalat (Észak-Amerika, Ázsia, Európa és Afrika térségéből) ${ }^{171}$ közremüködésével. A koalíció célja, hogy 2020-ra 80 százalékkal csökkentsék az online vadvilági kereskedelmet. ${ }^{172}$ Mivel az először kitűzött határidő lassan a végéhez közeleg, nehéz a teljes sikert várni. Azonban annyi mindenképpen remélhető, hogy csökkeni fog az olyan felületek száma, ahol ellenőrzés nélkül lehet CITES védelem alatt álló, gyakran a kihalás szélére sodródott fajok egyedeit megvásárolni.

Az internet szerepét a vadvilági kereskedelemben a CITES részes felei is felismerték, így a megfelelés és kikényszerítés kapcsán elfogadott határozatokban is foglalkoznak a kérdéssel. A részes feleknek ajánlják, hogy hozzanak létre egy olyan egységet, amely kifejezetten az internethez kapcsolódó vadvilági kereskedelmet vizsgálja; vagy a kérdéskört építsék be olyan szervek müködési körébe, amelyek kiberbüncselekményekkel foglalkoznak. Továbbá, megfelelő erőforrásokat kell biztosítani az online vadvilági kereskedelem megfigyelése és a hatékony fellépés biztosítása érdekében. ${ }^{173}$

\footnotetext{
${ }^{168}$ CITES I. cikk a)-b) pontok és (i)-(iii) alpontok.

${ }^{169}$ Eredeti angol nyelvű fogalom elnevezése: wildlife cybercrime.

${ }^{170}$ IFAW: International Fund for Animal Welfare, Állatjólét Nemzetközi Alapja.

171 A koalíció alapító vállalatai: Baidu, Baixing, eBay, Etsy, Facebook, Google, Huaxia Collection, Instagram, Kuaishou, Mall for Africa, Microsoft, Pinterest, Qyer, Ruby Lane, Shengshi Collection, Tencent, Wen Wan Tian Xia, Zhongyikupai, Zhuanzhuan and 58 Group.

${ }^{172}$ Leading tech companies unite to stop online wildlife traffickers. 2018. 03. 07.

https://www.ifaw.org/european-union/news/leading-tech-companies-unite-stop-online-wildlife-traffickers (2019. 01. 27.).

${ }^{173}$ Res. Conf. 11.3. (Rev. CoP. 17.) 7.p. Regarding e-commerce of specimens of CITES-listed species. 1112. pontok.
} 
A részes felek konferenciáin további döntések kerültek elfogadásra a vadvilági online büncselekményekkel kapcsolatosan. 2010-ben, Dohában a 15. részes felek konferenciáján az államok felé fogalmazták meg a következő ajánlásokat:

- nyújtsanak be információt a CITES Titkársághoz a legjobb gyakorlatokra és magatartási kódexekre vonatkozóan;

- publikáljanak tudományos kutatási eredményeket az internet használata és a vadvilági büncselekmények közötti összefüggésekre vonatkozóan, valamint ezeket az eredményeket osszák meg a CITES Titkársággal is;

- mérjék fel a CITES listára vett fajok internetes kereskedelmének mértékét;

- elemezzék az internet használatának elterjedése miatt a kereskedelmi útvonalakban és módszerekben bekövetkezett változásokat. ${ }^{174}$

A 2016 októberében Johannesburgban tartott részes felek konferenciáján több döntés is született az érintett tárgykörben. A részes felekre vonatkozóan a legjobb gyakorlatok és a releváns belső jogszabályozásban történt változások közlésének kérése történt, valamint felhívták az államok figyelmét, hogy keressék az online piacterek tulajdonosait és beszerzőit vadvilági kereskedelemre vonatkozó információk rendelkezésre bocsátása érdekében. ${ }^{175}$ A Titkárság a végrehajtásban betöltött szerepére támaszkodva segítséget és szakértelmet biztosít a vadvilági online bünözés felszámolására véghezvitt müveletekhez. Továbbá együttmüködik a Nemzetközi Rendőrségi Hivatallal az internethez füződő vadvilági bünözés hatékony legyőzése érdekében. ${ }^{176}$ Az Állandó Bizottságot felhívták egy olyan munkacsoport felállítására, amely mind a forrás, mind a célországokat tömöríti, amelyben részt vállalnak a nagy internetcégek, a nemzetközi szervezetek, jogászok és releváns szakemberek. ${ }^{177}$ A munkacsoport együttmüködik a Titkársággal. ${ }^{178}$

A szervezett bünözéshez és a korrupcióhoz kötődő szálak tekintetében már korábban megállapításra került, hogy a környezeti büncselekmény súlyos büncselekmény, amelyet gyakran szervezett bünözői csoportok követnek el. ${ }^{179}$ Az Európai Unió súlyos és szervezett bünözéssel kapcsolatos értékelése ${ }^{180}$ feltárta a környezeti büncselekmények

\footnotetext{
${ }^{174}$ Decision 15.57 Combating wildlife cybercrime.

175 Decision 17.92 Combating wildlife cybercrime.

${ }^{176}$ Decision 17.93 Combating wildlife cybercrime.

177 Decision 17.94 Combating wildlife cybercrime.

${ }^{178}$ Decisions 17.95 és 17.96 Combating wildlife cybercrime.

179 The Rise of Environmental Crime, 17. p.

${ }^{180}$ SOCTA: The EU Serious and Organised Crime Threat Assessment 2013.

Online elérhető: https://www.europol.europa.eu/sites/default/files/documents/socta2013.pdf.
} 
veszélyét, mint speciális veszélyt, amely fokozott figyelmet igényel. Az Európai Unió tagállamai körében végzett felmérések szerint a legtöbb, veszélyeztetett fajokkal kapcsolatos büncselekmény elkövetésének nyomozásakor feltártak a szervezett bünözéshez vezető nyomokat, azonban számos esetben a szisztematikus orvvadászat és kereskedelem, valamint a TOC összefonódása nem kerül vizsgálatra. A szervezett bünözői csoportok bizonyíthatóan ugyanazon útvonalakat használják fel az illegális vadvilági kereskedelemhez, mint más jogellenes árucikkek esetében. Amikor a súlyos büncselekményekhez való kapcsolat azonosításra kerül a tagállamok által, megfigyelhető a korrupcióhoz és megvesztegetéshez való kötődés, a vámiratok meghamisítása, a pénzmosás és más, jogellenes tevékenységek, amelyeket szervezett bünözői csoportok követnek el. ${ }^{181}$

Az illegális vadvilági kereskedelemben résztvevő szervezett bűnözői csoportok általában három fő kategóriába sorolhatók. A skála alján azok a helyi farmerek állnak, akik a jövedelmük kiegészítése érdekében adnak el fajokat. A második helyen a nagyobb, maffiajellegü szervezetek azonosíthatók, amelyek az elszegényedett földművesektől vásárolt egyedeket adják el, nagy profit mellett. Utóbbi csoportok különösen gyakoriak a fejlödő országokban. Végül, a jelentős nemzetközi csempészszervezeteket kell megemlíteni, amelyek sokszor egyéb illegális kereskedelmi tevékenység mellett folytatják a vadvilági termékekkel való üzletet. Ezeknél a csoportoknál gyakran megjelenik az erőszakra való hajlandóság, jelentős erőforrásokkal rendelkeznek, és ismerik a legfontosabb csempészútvonalakat. Így nemzetközi szinten ezek jelentik a legnagyobb fenyegetést. ${ }^{182}$ Ugyanakkor elmondható, hogy a fentiekben említett bünözői csoportok tevékenysége kiegészíti egymást. Hiszen közvetlenül helyi szinten szükség van olyan személyekre, akik a vadvilági termékeket begyüjtik, valamint az egyedeket elpusztítják vagy befogják. Ezek a személyek azonban csak nagyon elenyésző, szinte elhanyagolható profitra tesznek szert. Az igazi haszon a láncolat későbbi elemeinél: a csempészeknél, korrupt hatósági személyeknél és a végső eladóknál jelentkezik, akik termékeiket és egyedeiket az eredeti beszerzési ár többszöröséért adják tovább a kínálati oldal résztvevőinek. A vadvilági kereskedelem területén az ellátási lánc három fő elemből tevődik össze: az ellátóból, a kereskedőkből és a végső vevőkből, felhasználókból. A kezdeti ellátást az orvvadászok biztosítják, akiket általában két motívum vezérel: az önfenntartás vagy a profit. Habár egyes

181 The Rise of Enviornmental Crime, 35. p.

182 ZIMMERMAN, MARA E.: The Black Market for Wildlife: Combating Transnational Organized Crime in the Illegal Wildlife Trade. Vanderbilt Journal of Transnational Law Vol. 36, no. 5. 2003. november 1668. p. [Továbbiakban: ZIMMERMAN, 2003.]. 
orvvadászok a közösségük és saját fenntartásuk érdekében, illetve a gabonanövények védelme érdekében - amelyeket megdézsmálnak a nagy növényevők - végzik tevékenységüket, a leggyakoribb a profitorientált orvvadászat. A kereskedők alkotják a második elemet a láncolatban (,middlemen”), akik a termékek mozgatását biztosítják a beszerzési helyről a végső felhasználókhoz. A kereskedelmi tevékenység több résztvevő együttmüködésével történik, akik a szállítás és elosztás különböző fázisaiban tevékenykednek. Ök felelősek a beszerzőtől való elszállításért, a nemzetközi határokon való átjuttatásért, majd a végső eladóhoz és így később a vevőhöz való továbbításért. A szervezett bünözői csoportok hajlamosak és képesek a bűnelkövetési forma, célok és műveletek változtatására, amelyet nagyban befolyásol a kereslet, az egyes tevékenységek felderítési hatékonysága és az új büncselekményi lehetőségek. Így a TOC-ben résztvevő csoportok egyre inkább felismerték a vadvilági kereskedelemben rejlő lehetőségeket. A már régóta létező és új hálózatok - különösen Afrikában - már nemcsak fegyver- és drogkereskedelemből szereznek hasznot, hanem a nemesfémek, gyémánt, elefántcsont és rinocéroszszarv kereskedelemböl is. ${ }^{183}$

A vadvilági termékek és egyedek értékének növekedése a beszerzési helytől az eladásig mind az élő példányok, mind pedig a termékek esetében megfigyelhető. A szenegáli papagáj az egyik legkedveltebb, fogságban is jól tartható madár, amely különösen népszerü hobbiállat az Amerikai Egyesült Államokban és Európában. Bár az 1990-es évek óta bizonyítható, hogy csaknem minden papagájfaj jól szaporítható fogságban, az elmúlt három évtizedben körülbelül 3 millió szenegáli papagájt fogtak be a vadonból. A legnagyobb papagájexportőröknek Indonézia, a Fülöp-szigetek, Szenegál, Kamerun, Tanzánia és a Kongói Demokratikus Köztársaság számítanak. Az afrikai kontinensen ma is virágzó, csaknem teljesen ellenőrizetlen papagájkereskedelem az 1970-es, 1980-as években kezdődött. Újságírók tudósításaiból tudjuk, hogy a vadonból befogott szenegáli papagájpárokat, ketreccel együtt, körülbelül 30 USD-ért meg lehet vásárolni a nyílt utcán. A virágzó kereskedelmet tovább tüzeli a „középemberek” széles hálózata, akik a sokszor illegálisan befogott egyedeket tovább közvetítik a tengerentúlra. ${ }^{184}$ Egy másik kedvelt papagájfaj, az afrikai szürke papagáj egyedeit akár 750 USD áron kínálják, kedvelt online kereskedelmi oldalakon. Bár a szürke papagájok kereskedelme az 1990-es évek óta korlátozások alá

\footnotetext{
${ }^{183}$ WARCHOL-ZUPAN-CLACK, 2003. 7. p.

${ }^{184}$ Steve Boyes: The World's Most Traded Wild Birds? Senegal Parrots, color morphs, and the wild-caught bird trade... Naional Geographic, 2012. január 17.

https://blog.nationalgeographic.org/2012/01/17/the-worlds-most-traded-wild-birds-senegal-parrots-colormorphs-and-the-wild-caught-bird-trade/ (2018.12.27.).
} 
esik, a nyugat- és közép-afrikai vadonban hálóval, tömegesen befogott példányokat Európa, Kína, Dél-Afrika és a Közel-Kelet felé csempészik. Egyes természetvédők szerint az eredeti populáció mintegy 1 százaléka él már csak vadon. ${ }^{185}$ A madárbefogók, akik az egyébként hálóval könnyen tőrbe csalható egyedeket a vadonból beszerzik, mintegy 2060 centet kapnak minden példányért. Az afrikai kereskedők („közvetítők”) már 3-4-10 USD áron adják tovább a Szenegál-papagájokat, majd azok európai, amerikai nagykereskedőkhöz kerülnek, akik 35-40 USD áron kínálják a boltoknak a madarakat. A végső vásárló olyan 65-70 USD áron juthat hozzá a nem jogellenesen szerzett példányokhoz. Ha az illegális befogás és csempészet útján jutott el a kontinensre, akár 2000 USD-t ${ }^{186}$ is érhet egy-egy példány. ${ }^{187} \mathrm{Nem}$ csoda, hogy a hatalmas profit lehetősége felkeltette a szervezett bünözői csoportok figyelmét és az utóbbi évtizedekben megsokszorozódott az illegális vadvilági kereskedelemből származó haszon. Az így szerzett pénzügyi eszközöket gyakran akár terrorcselekmények finanszírozására használják fel. Bizonyítható, hogy az al-Káida terrorszervezett több mủveletének a pénzügyi biztosítása is így történt meg. A Szomália nagyrészét ellenőrzés alatt tartó al-Shabaab radikális fegyveres iszlamista csoport, amely többször hüségét fejezte ki az al-Káidának, a szomszédos Kenyában orvvadászatot folytat, és az elefántcsont eladásából szerzett profitot harcosok képzésére fordítja. Az al-Shabaab volt felelős a 2013-ben, Nairobiban történt Westgate bevásárló központban történt terrorcselekményért, ahol 62 civil és 5 kenyai katona vesztette életét. Így párhuzam vonható a terrorszervezetek és a vadvilággal kapcsolatos büncselekmények között. ${ }^{188}$ Tulajdonképpen egyik ország sem mentes a szervezett bűnözéstől; minden egyes államban találunk ilyen csoportokhoz tartozó személyeket. ${ }^{189}$

Számos országban jelent különösen nagy fenyegetést a vadvilág illegális kizsákmányolása. Példaként hozható fel Kolumbia, ahol egyes családok már generációk óta vadvilági termékekkel és egyedekkel folytatott kereskedelemből élnek. 2016 nyarán a kolumbiai rendőrség hírt adott a világ legnagyobb vadvilági kereskedelemmel foglalkozó

\footnotetext{
185 John Vidal: The grey parrot and the race against Africa's wildlife extinction. The Observer, 2016. szeptember 24.

https://www.theguardian.com/environment/2016/sep/24/cites-endangered-species-meeting-johannesburg (2018. 12. 27.).

${ }^{186}$ Channing Mavrellis: The Illegal Wildlife Trade: Sample Retail Market Prices. 2017. április 26. https://www.gfintegrity.org/illegal-wildlife-trade-sample-retail-market-prices/ (2018. 12. 27.)

$187 \mathrm{http}: / /$ www.cites.hu/tanari.html, cites_tananyag_2015. (2018. 12. 27.) 9. p.

${ }^{188}$ Edward Faulks: Al Qaeda profit from the trade of ivory. 2013. december 6. https://www.independent.co.uk/voices/comment/al-qaeda-profit-from-the-trade-of-ivory-8989151.html (2018. 12. 27.).

${ }^{189}$ FARER, TOM (szerk.): Transnational Crime in the Americas An Inter-American Dialogue Book. Routledge, New York. 1999. 13. p.
} 
csoportjának felszámolásáról. A Los Pajareros (The Birders) veszélyeztetett fajok államon belüli és nemzetközi illegális kereskedelméről vált ismertté. A gang feltételezett vezetői egy testvérpár, Jairo és José Luis Algarra Gutiérrez voltak, akik helyi, föként falusi környezetből származó beszállítóiknak 10 és 17 USD közötti összeget fizettek egyedenként. Az állatokat elkábították és elosztó központokként müködő farmokra vagy magánházakba szállították őket az eladóhelyeknek, valamint a vevőknek történő átadás előtt. A rendőrség becslései szerint a Los Pajareros által szállított egyedek közül körülbelül kilencven százalék minősült veszélyeztetettnek, és havonta mintegy 27 és 48 ezer USD közötti összeget kerestek. A nyomozás feltárta, hogy a csempészet során alacsony technológiai igényű eszközöket alkalmaztak, amelyek használata a drogcsempészek számára különösen rizikóssá váltak az elmúlt években. Azonban a vadvilági kereskedelemmel kapcsolatos tudatosság hiánya miatt a vadvilági kereskedelemben a régi, alacsony költségigényü csempészmódszerek is jól használhatók. Továbbá, alacsony kockázatú tevékenységnek minősül, hiszen jelenleg Kolumbiában a vadvilági kereskedelem büntetési tétele 4 és 9 év közötti és így nagyobb mértékben alkalmazhatóak az alternatív büntetési módszerek is. ${ }^{190}$

A drog-, ember- és fegyverkereskedelem, valamint a vadvilági kereskedelem számos hasonlóságot hordoz. Először is a legsérülékenyebbek, legtámadhatóbbak tekinthetők a büncselekmények áldozatának. A drogcsempészek és dílerek, az emberkereskedők és csempészek gyakran fiatal és szegény körülmények között élő személyeket céloznak meg a „piszkos munka” elvégzésére. Ugyanígy, a vadvilági kereskedelem tekintetében, a nemzetközi szervezett bűnözői csoportok gyakran kisebb pénzösszegek juttatásával ösztönöznek, vagy akár nyílt fenyegetéssel kényszerítenek helyi farmereket és falusiakat orvvadászatra. Ugyancsak hasonlóságként emelhető ki, hogy mind a négy büncselekményi kategória ún. „top-up” szisztéma alapján épül fel, vagyis a pénz a szindikátus néhány vezető pozícióban található személye felé árad, mindeközben a valódi rizikót és veszélyt vállaló személyek, akik a ranglétra alján helyezkednek el, alig részesednek a haszonból. További kettősség figyelhető meg a fejlődő és fejlett államok között. Amíg a drog-, ember-, és vadvilági kereskedelem esetében a termékek áramlása a fejlődő országok felől a fejlettek felé történik, addig a fegyverkereskedelem esetében ezzel pontosan ellentétes tendencia

190 James Bargent: Colombia Investigation Reveals Workings of Wildlife Traffickers. 2016. július 13. InSight Crime. https://www.insightcrime.org/news/analysis/colombia-investigation-reveals-workings-of-wildlife-traffickers/ (2018. 05. 25.). 
figyelhető meg. Végül, mind a négy büncselekményi kategória esetében felmerül a kérdés, hogy azok inkább egy mélyreható társadalmi probléma eredményei-e, vagy inkább kizárólag a végrehajtás és jogkikényszerítés hiányosságai engednek teret az említett cselekményeknek. ${ }^{191}$ A felmerülő hasonlóságok egyben jelentik azt is, hogy a vadvilági kereskedelem elleni harc során az államok és a bünüldöző szervek ugyanazokkal a nehézségekkel is szembesülnek, mint a drog, fegyver- és emberkereskedelem elleni évtizedek óta tartó fellépés során. Azzal a különbséggel, hogy mivel az illegális vadvilági kereskedelem és a vadvilággal kapcsolatos büncselekmények sokkal később keltették fel a nemzetközi közösség és az államok figyelmét, az első tapasztalatok csak mostanában kerülnek értékelésre. Elmondható, hogy a nemzetközi szervezetek segítségével számos olyan program került kidolgozásra, amelyek hiteles információt szolgáltathatnak a jelenlegi irányvonalak sikerességét illetően, további együttmüködésre sarkallva a helyi, regionális és globális szinteket.

Összefoglalva tehát, a vadvilági kereskedelem jogellenes formája a környezet elleni büncselekmények egyik legfontosabb formája. Jellemzői között megtalálható a határon átnyúló jelleg, a szervezett bünözés és a korrupció térnyerése. A biodiverzitás csökkenése megakadályozásának érdekében tett erőfeszítések közül kiemelkedő a veszélyeztetett, vadon élő fajok kereskedelmének szabályozása, a CITES elfogadása. Azonban a vizsgált szabályozási terület számos olyan jogi problémát felvet, amelyeket vagy nem láttak előre a nemzetközi szerződés megalkotásakor, vagy pedig azok újabban merültek fel. A következőkben vizsgálat tárgyát képezi a Washingtoni Egyezmény mint multilaterális környezeti egyezmény és a felvetett nemzetközi közjogi és egyéb jogterületekhez kötődő kérdések.

${ }^{191}$ HARRIS, MichaEl R.: The Role of Law, Society and Ethics within Wildlife Importing Countries. Quinninpiac L. Rev. Vol 33. (2015.) 516. p. 


\section{IV.1. A CITES helye a nemzetközi környezetvédelmi jogban}

A környezeti etika az ember és a természetes környezet közötti morális kapcsolatként fogalmazható meg. A környezetjogi szabályozás a mögötte meghúzódó komplex morálrendszer közül mindig is az emberközpontú, úgynevezett antropocentrikus megközelítést követte. Egyes álláspontok szerint a napjainkban meghúzódó súlyos környezeti válsághelyzetekért is ez a megközelítés hibáztatható. Egy példával szemléltetve, mivel az emberközpontú megközelítés az egész természeti környezetet és annak minden elemét az ember fennmaradása érdekében kezel, az egyes természeti elemek önálló értéke elveszik, azokat nem veszik figyelembe, elvezetve olyan súlyos környezeti problémákhoz, mint a klímaváltozás, a biológiai sokféleség csökkenése és a levegőszennyezés. ${ }^{192}$ Ezzel szemben az ökocentrikus megközelítések ,az ökoszisztémát mint egészet is morális státusszal rendelkezönek tekintik, és ezt tartják a legföbb védendö értéknek."193

A nemzetközi környezetvédelmi jog fejlödése az alábbiakban röviden kiemelt több korszakra, szakaszra bontható. A nemzetközi környezetvédelmi jog fejlődése viszonylag későn, a XX. század elején indult. Természetesen, korábbi történeti időszakokban is találkozhatunk egy-egy faj vagy terület védelmével, azonban ezek eseti jellegűek voltak, államok vagy uralkodók belső, állami szabályozásán alapultak, sokszor inkább spirituális mintsem gyakorlati jellegü megfontolások által vezetve. ${ }^{194}$ Nemzetközi szinten az elmúlt század elején kezdődött meg a környezetvédelmi normaalkotás. A nemzetközi környezetvédelmi jog korszakhatárait az ENSZ keretében rendezett konferenciákhoz kötjük, ahol a legfontosabb környezeti jelentőségü dokumentumok is elfogadásra kerültek.

Az első korszak, amely 1900-1945-ig tartott, főként a felismeréshez kötődik. Ebben az időszakban az államok ráébredtek, hogy a fejlődés és az iparosítás folyamata magával vonja a különböző környezeti tényezők kizsákmányolását, a környezet nagymértékü szennyezését és így szükségessé válik a jogi keretek, szabályozás pontos kidolgozása. A kezdet a kétoldalú halászati megállapodások időszaka volt. Elfogadásra került 1902-ben a Párizsi Egyezmény a mezőgazdaság számára hasznos madarak védelméről, ${ }^{195}$ 1911-ben

\footnotetext{
${ }^{192}$ Environmental Ethics: Between Anthropocentrism and Ecocentrism. http://home.iitk.ac.in/ anubha/CE213.pdf (2019. 08. 09.).

${ }^{193}$ A környezetetikai kérdésekről bővebben: KovÁCS JÓzSEF: Környezeti etika. Világosság. 9-10. szám, 2008. 75-108. p.

${ }^{194}$ FARKAS CSAMANGÓ ERIKA: Környezetjogi szabályozások. Egyetemi Jegyzet, SZTE ÁJTK, Üzleti Jogi Intézet., 2017. 32. p.

${ }^{195}$ Convention for the Protection of Birds Useful to Agriculture. A mezőgazdaság számára hasznos madarak védelméröl szóló egyezmény. 1902. (1905.) Párizs Kihirdette: 1906. évi I. törvény.
} 
az USA és Nagy-Britannia kötött egyezményt ${ }^{196}$ a prémes fókák védelméről. Az első olyan nemzetközi egyezmény, amelynek célja a vadvilág védelme volt egy adott régióban, 1900-ban került elfogadásra az afrikai gyarmatokkal kapcsolatosan, amelyet az ugyanebben a tárgykörben, 1933-ban elfogadott szerződés ${ }^{197}$ írt felül. 1937-ben írták alá a bálnavadászatot szabályozó nemzetközi egyezményt, ${ }^{198}$ amelyet 1946-ban, Washingtonban, továbbfejlesztett változatban is elfogadtak. ${ }^{199}$

A második korszak szorosan kötődik az ENSZ-hez, és annak szakosított intézményeinek létrehozásához. Az intézményesités időszaka az 1972 júniusában, Stockholmban tartott „ENSZ Konferencia az Emberi Környezetröl" ${ }^{200}$ megtartásával ért véget. Ebben az időszakban olyan nemzetközi szervezetek és programok sora került felállításra, amelyek környezetvédelmi jelentőséggel bírnak. Példaként említhető az IUCN, az UNESCO MAB programja, vagy a FAO tevékenysége a mezőgazdasági kemikáliákkal kapcsolatban. Az 1949-ben létrehozott Európa Tanács is jelentős szerepet játszott, elsősorban a természetvédelem és vízügy terén, széleskörü nemzetközi szerződésalkotási tevékenységével hozzájárulva a környezetvédelmi szabályozás fejlődéséhez. Különböző jogi szabályozások kerültek kidolgozásra, regionális és univerzális szinten is, például a szennyezőforrásokkal, így az olajszennyezéssel, nukleáris teszteléssel, lápokkal, tengeri élővilággal, édesvizek minőségével kapcsolatosan.

A harmadik korszak 1972-től indult és ugyancsak egy ENSZ Konferencia ${ }^{201}$ - „ENSZ Környezet és Fejlődés Konferencia” - zárta 1992 júniusában, Rió de Janeiroban. A Konferencia megteremtette a kapcsolatot a környezetvédelem és a fejlődés között a fenntartható fejlődést és annak fogalmát állítva a középpontba. A 27 alapelvből álló nyilatkozat a környezetvédelem minden területére kiterjed. A Konferencián két meghatározó jelentőségű egyezményt is elfogadtak: az Éghajlatváltozásról szóló Keretegyezményt ${ }^{202}$ és a

\footnotetext{
${ }^{196}$ North Pacific Fur Seal Convention, 1911. (1911.) Washington.

197 The Convention Relative to the Preservation of Fauna and Flora in the Natural State. 1933. (1933.) London.

${ }^{198}$ International Agreement for the Regulation of Whaling. 1937. (Kiegészítő Jegyzőkönyv: 1938., 1945.), London.

${ }^{199}$ International Convention for the Regulation of Whaling 1946. (1946.) Washington. Magyarország egyazon napon lépett be az ICRW-be (The International Convention for the Regulation of Whaling) és az Európai Unióba.

${ }^{200}$ Stockholm, The United Nations Conference on the Human Environment, 1972. jún. 5-16.

${ }^{201}$ Rio de Janeiro, The United Nations Conference on Environment and Development (UNCED), 1992. jún. 3-14.

${ }^{202}$ United Nations Framework Convention on Climate Change. Az Egyesült Nemzetek Szervezetének Klímaváltozásról szóló Keretegyezménye.1992. (1994.) New York UNTS 1771107 p.
} 
Biológiai Sokféleség Egyezményt ${ }^{203}$. Az Agenda 21 program pedig irányt jelöl a XXI. század számára. A program 40 fejezetből áll, és mintegy 800 oldalon keresztül részletezi a jelen században elvégzendő feladatokat és fő célkitüzése, hogy megoldást találjon az évszázad környezeti kihívásaira. A program jelentősége a kormányok azon felismerése, hogy világméretü összefogás szükséges a problémák orvoslására és, hogy a fenntartható fejlődés jegyében összehangolják a gazdasági fejlődés és az egészséges környezet iránti igényt. Ebben a korszakban az ENSZ egy hatékony koordinációs rendszert igyekezett kidolgozni és müködésbe helyezni, a nemzetközi környezeti kérdésekre való válaszadásként. Regionális és univerzális egyezményeket fogadtak el, és elsőként került betiltásra bizonyos termékek gyártása, fogyasztása és nemzetközi kereskedelme.

A negyedik korszak napjainkban is tart. Ez a korszak föként arról szól, hogy a nemzetközi környezeti és környezetvédelmi kérdések hogyan integrálhatók más kérdéskörökbe, illetőleg azokat hogyan lehet hatékonyan érvényesíteni: így hangsúlyossá vált a nemzetközi környezeti elöírások és vállalt kötelezettségek, akár bírói úton való kikényszerítése. ${ }^{204} \mathrm{Az}$ ENSZ keretében tartott konferenciák sora folytatódott, 2002-ben Johannesburgban (Fenntartható Fejlödés Világkonferencia) ${ }^{205}$, majd 2012-ben újra Rióban ${ }^{206}$ találkoztak az államok.

A CITES-t 1973-ban írták alá, vagyis történeti szempontból a környezetvédelmi jog fejlődésének harmadik korszakához kötődik. A CITES kettős céllal jött létre: először is annak érdekében, hogy megállítsa a vadon élő állat- és növényfajok eltünését, másrészt a kihalással fenyegetett fajok védelmének előmozdítása érdekében ${ }^{207}$. Az Egyezmény azonban nem minden veszélyeztetett faj védelmét foglalja magában, csupán azokra tér ki, amelyeket érint vagy érinthet a nemzetközi kereskedelem. Nem vitás, hogy az államok bizonyos kockázatot is vállaltak a CITES megalkotásával, hiszen nem álltak

\footnotetext{
${ }^{203}$ Convention on Biological Diversity. A biológiai sokféleségről szóló egyezmény. 1992. (1993.), Rio de Janeiro UNTS 1760 79. p. Kihirdette: 1995. évi LXXXI. törvény.

204 A nemzetközi környezetjog fejlődéséről bővebben: SANDS, PHILIPPE: Principles of International Environmental Law. Third Edition. Cambridge University Press, Cambridge, 2012. 22-49. p.

205 Johannesburg, The World Summit on Sustainable Development 2002. aug. 26 - szept. 4.

${ }^{206}$ Rio + 20, The United Nations Conference on Sustainable Development 2012. jún. 20-22.

${ }^{207}$ Ezt támasztja elő az Egyezmény preambuluma is, amely a következőképpen szól: ,a Szerződö Államok, felismerve, hogy a vadon élö állatok és növények sok szép és változatos formájukban a föld természeti rendszereinek pótolhatatlan részét képezik, amelyeket a jelen és a jövö nemzedékek számára meg kell óvni, tudatában annak, hogy a vadon élö állatok és növények egyre nagyobb esztétikai, tudományos, kulturális, pihenési és gazdasági értéket jelentenek, felismerve, hogy a népek és Államok saját vadon élö állat- és növényviláguk legjobb oltalmazói, illetöleg azoknak kell lenniük, felismerve továbbá, hogy a nemzetközi együttmüködés alapvetö jelentöségü a vadon élö állatok és növények bizonyos fajainak a nemzetközi kereskedelem útján történö túlzott mértékü kiaknázásától való megóvásában, meggyözödve az e célt szolgáló megfelelö intézkedések megtételének sürgösségéröl."
} 
rendelkezésre pontos adatok a veszélyeztetett fajok kereskedelméröl, így megbecsülni sem lehetett a szabályozás környezeti és gazdasági hatásait. ${ }^{208}$ A kereskedelemmel érintett fajok védelme elképzelhetetlen nemzetközi szabályozás nélkül, hiszen azok kereskedelme országhatárokon, sokszor kontinenseken átívelő jelenség. A CITES 1975 júliusában lépett hatályba, a tizedik ${ }^{209}$ ratifikációs okmány beérkezése után, jelenleg 183 állam részes fél az Egyezményben. Elmondható, hogy jelentős nemzetközi támogatottság áll mögötte.

A CITES-hez kapcsolódóan ki kell emelni a biodiverzitás megőrzése érdekében elfogadott egyezményeket. A biológiai sokféleség vagy biodiverzitás kifejezés az elmúlt évtizedek ökológiai válsága nyomán vonult be a köztudatba.

A biológiai sokféleség fogalma első pillantásra egyszerűen értelmezhető, hiszen minden laikus számára is egyértelmü, hogy egy adott területen (ez a kutatások tekintetében általában $1 \mathrm{~m}^{2}$ területet jelent) minél több faj van jelen, annál nagyobb a biodiverzitás mértéke. Azonban a biológiai sokféleség nem csupán a fajok számát jelenti, hanem mintegy öt jelentése van. Így jellemezhető „,a) a féleségek (például fajok, populációk vagy gének) számával; b) az egyenletességgel, azaz a féleségek relatív gyakoriságával; c) a féleségek különbözőségének fokával; d) a megfigyelhető térbeli és e) időbeli mintázatokkal." ${ }^{210} \mathrm{~A}$ globálisan folytatott vizsgálatok az első típussal foglalkoznak, így a nemzetközi környezetvédelmi szabályozás szempontjából is ennek van a legnagyobb jelentősége. Az elmúlt száz esztendőben a nemzetközi közösség felismerte a környezetvédelem gondos jogi szabályozásának szükségességét. A jogi szabályozás tárgya és módszere is változáson ment keresztül, hiszen elmozdulás történt az átfogó és kiterjedt egyezmények elfogadása felé. Azonban a nemzetközi környezetjogi irodalom is hangsúlyozza, hogy fel kell ismerni az átfogó jogi rendszer szükségességét, mint az ún. ökoszisztéma-felfogás fontos elemét. A környezetjogban elterjedő új megközelítés szerint olyan szabályozási rendszer megalkotására van szükség, amely a jogi határok helyett az ökológiai határokat veszi figyelembe azzal a célkitüzéssel, hogy az emberi szükségletek kielégítése az ökoszisztéma integritásának és működésének fenntartása mellett történjen. Ez a kettős felfogás számos nemzetközi dokumentumban megjelenik, így a Malawi alapelvekben is, amely 1998-ban került

\footnotetext{
${ }^{208}$ Legislative Development: Conventionon International Trade in Endangered Species of Wild Fauna and Flora. Law and Policy in International Business,Vol. 6. (1974) 1211-1228. p.

${ }^{209}$ Amerikai Egyesült Államok, Nigéria, Svédország, Tunézia, Svájc, Ciprus, Ecuador, Chile, Uruguay és Kanada.

${ }_{210}$ BAJOMI BÁLINT: A biológiai sokféleség és jelentősége. KOVÁSZ, VIII. évfolyam, 1-4. szám 2004. Tavasz - Tél, 7-14. p.
} 
elfogadásra ${ }^{211}$ a Biológiai Sokféleség Egyezmény részes államainak ötödik konferenciáján. Azonban az ökoszisztéma felfogás érvényesítése előtt számos akadály áll, így a környezetjog töredezettsége, a mérlegelésen alapuló vagy „,soft law” jellegű normák alkalmazásának kérdésessége, valamint a nemzetközi környezetjog alapelveinek alkalmazása is inkább az érintett jogalkalmazó szervek gyakorlatán múlik. ${ }^{212}$ A biológiai sokféleség csökkenésének megakadályozása érdekében hozott nemzetközi egyezmények közül nyilvánvalóan azok minősülnek a leghatékonyabbnak, amelyek vagy egy egész területet helyeznek védelem alá, vagy pedig általános szabályokat fogalmaznak meg a biológiai sokféleség védelme érdekében. Ha egy adott területen csupán egy-egy fajt helyezünk védelem alá, az önmagában lehet, hogy annak kiemelt védelmet biztosít, de attól a környezetpusztítás és egyéb romboló tevékenységek a védett faj fennmaradását ugyanúgy veszélyeztetni fogják. Így mivel az ökoszisztéma komplex rendszer, a védelmére alkotott szabályoknak is komplexnek kell lenniük. A nemzetközi környezetjogban új tendenciaként megjelenő ökoszisztéma-felfogás is ennek a gondolatnak a mentén alakult ki, azonban hatékony érvényesüléséhez szükséges szemléletváltás várhatóan még hosszabb időt vesz igénybe a kormányok és a társadalom részéről is. ${ }^{213}$

Kérdésként merül fel, vajon a CITES a széleskörü szabályozási rendszer melyik területén helyezhető el? Amennyiben a biológiai sokféleséget a nemzetközi környezetjog, vagy általánosságban véve a jog szabályozásának tárgyaként kezeljük, ez négy módon képzelhető el. ${ }^{214}$ Az első, és a környezetvédelemben elsőként megvalósuló szabályozási forma az, ha egy-egy fajt részesítünk védelemben. A második lehetőség, hogyha nem egy-egy fajra korlátozzuk a szabályozást, hanem kiterjesztjük azt, és egy adott természeti terület megőrzése érdekében alkotunk egyezményt, természetesen az ott élő fajok védelmével együtt. Mind a két szabályozásnak megvannak a maga előnyei és hátrányai, azonban elözetesen annyi mindenképpen megállapítható, hogy az utóbbi szabályozási forma igényli az elfogadó államok kompromisszumkészségét egy kiterjedt szabályozás elfogadásáért. Az előbbi szabályozási forma már a XX. század elején megvalósult, mind regionális mind univerzális szinten. Néhány fontosabb példa egy-egy vagy néhány faj tekintetében az

${ }^{211}$ Malawi Principles for the Ecosystem Approach. Malawi, 1998. január 26-28.

212 VoIGHT, Christina: Rule of Law for Nature, New Dimension and Ideas in Environmental Law. Cambridge University Press, Cambridge, 2013. 158-175. p.

${ }^{213}$ Ökoszisztéma megközelítésröl bövebben: The Ecosystem Approach. The Secretariat of the Convention on Biological Diversity, Montreal 2004. https://www.cbd.int/doc/publications/ea-text-en.pdf

${ }^{214}$ Szerző saját csoportosítása. 
1973. évi egyezmény a jegesmedvék védelméröl, ${ }^{215}$ és ide sorolhatók a nemzetközi jog első korszakában alkotott már említett egyezmények is. A második szabályozásra is számos példát hozhatunk fel: 1950. Párizs, Egyezmény a madarak védelméről, így az ismert Ramsari Egyezmény ${ }^{216}$ a nemzetközi jelentőségü vadvizekről, amelyet 1971-ben fogadtak el, a Bonni Egyezményt a vándorló, vadon élő állatfajok védelméről (1979), ${ }^{217} 1975$ ben az Amazonas területének védelméről alkottak egyezményt, ${ }^{218}$ 1992-ben Közép-Amerika területének védelméröl, ${ }^{219}$ 2003-ban pedig a Kijevi Egyezményt fogadták el a Kárpátok fenntartható fejlődéséről. ${ }^{220}$ Mindemellett el kell különítenünk azokat a nemzetközi egyezményeket, amelyek önmagát a biodiverzitást teszik a szabályozás tárgyává. Ilyen egyezmény az 1992-ben elfogadott Biológiai Sokféleség Egyezmény. Ezen túl el kell különítenünk azokat a nemzetközi egyezményeket, amelyek nem kifejezetten a környezetet védik, azonban olyan szektorális szabályokat tartalmaznak, amelyek közvetve szolgálják a biológiai sokféleség megőrzését. Rendszertani szempontból a CITES is utóbbi kategóriába sorolható.

${ }^{215}$ Agreement on the conservation of Polar Bears. 1973. (1976.), Oslo UNTS Vol. 2898 243. p. (Magyarország nem részes fél.).

${ }^{216}$ Convention on wetlands of international importance especially as waterfowl habitat (Ramsar Convention). A nemzetközi jelentőségü vadvizekröl, különösen mint a vízimadarak tartózkodási helyéröl szóló, Ramsarban, 1971. február 2-án elfogadott egyezmény és a Kiegészítő Jegyzőkönyvek: 1982., 1987. 1971. (1975.) Kihirdette: 1979. évi 28. tvr. A Jegyzőkönyvekkel egységes szerkezetben: 1993. évi XLII. törvény. ${ }^{217}$ The Convention on Migratory Species of Wild Animals. (Bonn Convention) A vándorló vadon élö állatfajok védelméröl szóló egyezmény. 1979. (1983.) Bonn Kihirdette: 1986. évi 6. tvr.

${ }^{218}$ Agreement for the conservation of the flora and fauna of the Amazonian territories. 1975. (1976.) Lima UNTS 1056127 p. (Magyarország nem részes fél.).

${ }^{219}$ Convention for the Conservation of the Biodiversity and the Protection of Priority Wilderness Areas in Central America 1992. (1994.) Managua (Magyarország nem részes fél.).

${ }^{220}$ The Carpathian Convention. A Kárpátok védelméröl és fenntartható fejlődéséről szóló keretegyezmény. 2003. (2006.) Kijev Kihirdette: 306/2005. (XII. 25.) Korm. rend. 


\section{IV.2. Intézményi, szervezeti kérdések}

Természetesen az egyezményi rendszer müködtetéséhez nélkülözhetetlen egy adminisztratív müködési keret létrehozása. Ez a CITES vonatkozásában a Titkárság, amelynek központja Genfben található. Az Egyezmény XII. Cikkének első bekezdése írja elö, hogy a Titkárságról az Egyesült Nemzetek Környezetvédelmi Programjának Végrehajtó Igazgatósága gondoskodik, amely megállapodást kötött az IUCN-nel ${ }^{221}$ a Titkárság működtetéséről. A Tiktárság finanszírozása korábban az UNEP részéről történt. Napjainkban a szervezet finanszírozását az ún. CITES vagyonkezelői alap biztosítja, amely elsősorban a tagok hozzájárulásából tartja fenn magát. Azonban lehetőség van arra is, hogy alkalmanként külső támogatást is juttassanak a Titkárságnak az Egyezmény céljai elérésének elősegítésére. Példaként megemlíthető, amikor az Európai Bizottság is mintegy 1 millió eurót juttatott annak érdekében, hogy a CITES végrehajtása minél hatékonyabban történjen meg a fejlődő országokban. Ehhez a kezdeményezéshez más államok is csatlakoztak, így az Amerikai Egyesült Államok, Dánia, Franciaország, Japán, Norvégia, Észak-Írország, Nagy-Britannia és Katar. A CITES létrejöttének 35. évfordulóján, 2010-ben, a Genfi Természettörténeti Múzeumban rendeztek különleges fogadást Svájc támogatásával. ${ }^{222} \mathrm{~A}$ Titkárság feladatait részletesen az Egyezmény XII. Cikke határozza meg, amelynek köre átfogja a mindennapi adminisztratív feladatok elvégzését, de idetartozik a tudományos és kutatási feladatok ellátása is. Éppen ezért az Egyezmény hatékonysága nagyban függ a Titkárság kapacitásától. Emiatt az eredetileg tizenegy személyt foglalkoztató Titkárság mára kiterjedt szervezetrendszerré vált. ${ }^{223}$

A Titkárság munkáját az Állandó Bizottság segíti, különösen az Egyezmény végrehajtása tekintetében, továbbá vannak a költségvetéssel kapcsolatos funkciói is. Az Állandó Bizottság tagjai a hat nagyobb földrajzi régiót (Afrika, Ázsia, Európa, Észak-Amerika, Közép- és Dél-Amerika és a Karibi térség, valamint Óceánia) képviselő tagokból áll. ${ }^{224}$ 1987-ben az Ottawai Konferencián kerültek megalakításra az Állat- és Növény Bizottságok, amelyek szakértők bevonásával segítik az érintett területekre vonatkozó kereskedelmi szabályok megalkotását. ${ }^{225}$

\footnotetext{
${ }^{221}$ IUCN: mind államok, mind kormányzati és nem-kormányzati szervek is egyaránt tagjai lehetnek. Az IUCN-nek jelenleg mintegy 1200 tagja van.

${ }^{222}$ How is CITES Financed? https://cites.org/eng/disc/fund.php (2018. november 02.).

${ }^{223}$ The CITES Secretariat https://cites.org/eng/disc/sec/index.php (2018. november 02.).

${ }^{224}$ Standing Committee https://cites.org/eng/disc/sc.php (2018. november 02.).

${ }^{225}$ Animals and Plant Committees https://cites.org/eng/disc/ac_pc.php (2018. november 02.).
} 
A szervezeti struktúrában legnagyobb jelentőséggel a Részes Felek Konferenciája bír, amely minden második vagy harmadik évben újratárgyalja a legfontosabb kérdéseket: a Függelékekben szereplő fajok listáját, az Egyezményhez való csatlakozás lehetőségét, a végrehajtás sikerességét. Az utóbbi érdekében programokat alkot, és mindezen kérdéseket határozatokba és döntésekbe foglalja. A tizenhetedik Konferenciát 2016. szeptember 25. és október 5. között Johannesburgban tartották. ${ }^{226} 2019$. május 23. és június 03. között időszakra tervezték a következő, 18. konferenciát, amelynek helyszíne Colombo, Sri Lanka lett volna. ${ }^{227}$

Az Egyezmény elnyerte az államok széles körü támogatását és a részes felek száma is dinamikusan nőtt. 1976-ra huszonnyolc állam ratifikálta az Egyezményt, és a tagok száma $^{228}$ folyamatosan növekedett egészen napjainkig. Azonban éppen ezért szükséges, hogy az Egyezmény is folyamatosan alkalmazkodjon az újonnan csatlakozó államok igényeihez, és a nagyobb taglétszám mellett a végrehajtás továbbra is hatékony tudjon maradni. Emiatt bírnak olyan kiemelt jelentőséggel a Részes Felek konferenciái, hiszen az ott elfogadott határozatokon keresztül tudnak alakítani a fennálló rendszeren, szabályokon, így alkalmazkodva a kihívásokhoz. Azonban az újító szabályok elfogadása nem csak az elmúlt időszakra jellemző, hanem ha végig tekintjük a CITES történetét - eltérően a legtöbb nemzetközi egyezménytől - az sohasem volt statikus rendszerként leírható. Véleményem szerint inkább jellemezhető az eredeti alapokon és értékeken nyugvó, de folytonosan változó, dinamikus szabályanyagként.

Ez megmutatkozott a kezdeti időszakban is, hiszen már az első, 1976 novemberében, Bernben tartott konferencián is jelentős módosításokat eszközöltek. A CoP-n részt vett az akkori 22 részes állam mellett 12 megfigyelő is, továbbá számos érdeklődő nemzetközi szervezet is jelen volt. A kezdeti időszakban legfontosabb teendő az Egyezmény aláírása óta felismert problémákra való válaszadás és a továbbfejlesztés lehetőségének a megteremtése volt, amellyel kapcsolatosan a felek számos javaslatot tettek. Azonban itt meg kell említeni egy hatásköri kérdést, amely azóta sem került rendezésre. A felek két, illetve háromévente tartott találkozói elsősorban nem az Egyezmény módosításának érdekében

${ }^{226}$ Conference of the Parties https://cites.org/eng/disc/cop.php (2018. november 02.).

${ }^{227}$ CITES Calendar https://www.cites.org/eng/news/calendar.php (2019. 02. 16.).

A 18. részes felek konferenciája eredetileg 2018. május 23. és június 3. között került volna megtartásra, Colombóban. Azonban a Sri Lankában kialakult biztonsági kockázat miatt azt elhalasztották és 2018. augusztus 17. és 28. között, Genfben lesz. Mivel jelen értekezés kézirata 2018. augusztus 10-én lezárásra kerül, a 18. CoP-n elfogadott döntések és határozatok már nem képzik a feldolgozott háttéranyag részét.

${ }^{228}$ List of Partiest to the Convention https://www.cites.org/eng/disc/parties/index.php (2018. november 02.). 
kerülnek megtartásra, hanem a Függelékben szereplö állatfajok listájának felülvizsgálata miatt. ${ }^{229}$ Az Egyezmény érdemi módosítása annak XVII. Cikke alapján történik, amely előírja a rendkívüli ülésszak összehívását. ${ }^{230}$ Visszatérve az első konferenciára, a tanácskozás alapvetően két bizottság: a Tudományos, valamint az Adminisztratív és Jogi Bizottság keretei között zajlott. A Tudományos Bizottság elsősorban a Részes Felek által a Függelékekbe felvételre javasolt állat- és növényfajokkal foglalkozott. Így a legnagyobb veszélyben lévő fajok, mint a krokodilok, tengeri teknősök, föemlősök, elefántok, prémes fajok, pitonok és boák és a préri madarai, a cikászok, az Arecaceae pálma, a fa páfrányok és a Didiereaceae (szegfüvirágúak) kerültek fel a listára. Továbbá, két hipotézis igazolódott be a felvételi folyamat során: inkább olyan fajokat is listára vesznek, amelyeknél a bizonyítékok tisztázatlanok, mintsem fordított irányba tévedjenek. Ezen túl inkább magasabb rendszertani kategóriákat helyezzenek védelem alá, mintsem alfajokat. Ezzel kapcsolatosan elkeserítő példaként hozható fel az afrikai elefántok populációja, amely megmutatja, egyes országok kitartó ellenállása miként gyengítheti meg a CITES védelmi vonalának tartóoszlopait, és hogyan hatnak a kereskedelmi könnyítések az illegális vadászatra. A Tudományos és Jogi Bizottság munkájának eredményeképpen határozatok születtek különleges munkacsoportok létrehozásáról végrehajtási kérdések tekintetében, a Titkárság későbbi kilátásairól és természetéről, valamint a nem részes felek későbbi csatlakozási lehetőségeiröl. ${ }^{231}$

Eddig összesen tizenhét CoP-t tartottak, ${ }^{232}$ a Részes Felek országainak különböző városaiban, ahol számos határozatot fogadtak el az Egyezmény egyes szakaszainak értelmezéséről, az egyes fajokra vonatkozó végrehajtási szabályokról, ${ }^{233}$ valamint számos egyéb témakörről, mint a például besorolási kérdések ${ }^{234}$ és együttmüködési megállapodások.

\footnotetext{
${ }^{229}$ Az Egyezmény kapcsán elfogadott határozatok és döntések kérdésköréről a dolgozat további fejezeteiben részletesen szó lesz.

${ }^{230}$ CITES XVII. Cikk, 1. bekezdés. „A Titkárság tartozik összehívni a Részes Felek konferenciájának rendkívüli ülésszakát, ha a Részes Felek legalább egyharmada írásban kéri az Egyezmény módosításának megvitatását és elfogadását. Az ilyen módositásokat a jelenlevő és szavazó Részes Felek kétharmados többségének kell elfogadnia. Ebböl a szempontból a ,jelenlevő és szavazó Részes Fél” kifejezés a jelenlevő és igennel vagy nemmel szavazó Részes Feleket jelenti. A szavazástól tartózkodó Részes Felek nem számítanak be a módositás elfogadásához szükséges kétharmadba."

${ }^{231}$ NAVID, DANIEL: Trade in Endangered Species: The Washington Convention: First Meeting of the Conference of the Parties. Environmental Policy and Law, Vol. 2 (1976) 167-170. p.

${ }^{232}$ A részes felek 18. konferenciáját az értekezés kéziratának lezárása után, 2019. augusztusában tartották.

${ }^{233}$ Res.s Conf. 9.20. (CoP 15); Conf. 10.10. (CoP 16); Conf. 10.13. (CoP 15); Conf 13.4. (CoP 16).

${ }^{234}$ Res. Conf. 12.11 (CoP 16).
} 
2013 márciusában került bevezetésre az ún. „World Wildlife Day”, amely a CITES aláírásának évfordulója, március 3-a lesz minden évben. Ezen túl határozatokat fogadtak el többek között a Titkárság 2015-2016 közötti finanszírozásáról, más biológiai sokféleséghez kapcsolódó egyezményekkel való együttmüködésről, kiemelten a GSPC-vel, ${ }^{235}$ a CITES-hez való csatlakozás következményeiről a szegények megélhetésére vonatkozóan, és a Tudományos Hatóságok munkájának segítéséről a fajok veszélyeztetettségének vizsgálata tekintetében. Kiemelt jelentőségü, hogy 2013-ban elfogadtak két Akciótervet: az afrikai elefántokra vonatkozóan és egy átfogóbb jelentőségüt, amely egészen 2020-ig irányt mutat az Egyezmény tekintetében.

Ez utóbbi, a CITES Stratégiai Vizió 2008-2020236 elnevezést viselő dokumentum is kimondja, hogy az 1975 óta hatályban lévő Egyezmény a részes felek konferenciáin elfogadott határozatokon keresztül eddig képes volt alkalmazkodni a változó körülményekhez, és konstruktív gyakorlati megoldásokat dolgoztak ki a különösen bonyolult vadvilági kereskedelmi és megőrzési kérdések tekintetében. Már 1994-ben Fort Lauderdaleben felmerült, hogy az Egyezményt hatékonysági szempontok alapján felül kellene vizsgálni, hogy az a következő évtizedek kihívásaihoz is alkalmazkodni tudjon. 1997-ben Hararéban állapodtak meg a felek egy Akcióterv elfogadásában, amely az említett változtatásokra reagál. A 2000-ben elfogadott Stratégiai Vizió 2005 és Akcióterv érvényességét 2004-ben meghosszabbították. A fó célkitüzés a biodiverzitás csökkenésének jelentős mérséklése volt 2010-ig, valamint a fenntartható fejlesztés koncepciójának integrálása az Egyezménybe. A legutóbbi, tizenhetedik konferencián a felek meghosszabbították az Akcióterv érvényességét egészen 2020-ig, kiegészítéseket téve a Biodiverzitási Akcióterv 2011-2020 folytatására, és tekintettel az Aichi Biodiverzitási Célokra, ${ }^{237}$ valamint az Egyesült Nemzetek Fenntartható Fejlődés Konferenciájának lehetséges kimenetelére. Ezzel az új Stratégiai Elképzeléssel kívánják a CITES-t bevezetni az új évezredbe, és az alkalmassá tenni az új kihívásokra való reagálásra. Ennek két fö célja van: először is az Egyezmény müködésének fejlesztése, így a nemzetközi növény-és állatvilágra vonatkozó kereskedelem fenntartható keretek között lesz folytatható, másodsorban annak elősegítése, hogy a CITES irányvonalának fejlesztése összeegyeztethető legyen a nemzetközi

\footnotetext{
${ }^{235}$ Global Strategy for Plant Conservation of the Convention on Biological Diversity.

${ }^{236}$ CITES Strategic Vision: 2008-2020.

${ }^{237}$ Aichi Biodiversity Targets, összesen 20 cél, öt (A-E) stratégiai célkitűzés alá rendelve, amely egy tíz éves keretet szab a biodiverzitás csökkenése elleni harcra.

Bövebben: Strategic Planform Biodiversity and the Aichi Biodiversity Goals. https://www.cbd.int/doc/strategic-plan/2011-2020/Aichi-Targets-EN.pdf (2018. november 02.).
} 
prioritásokkal, és számításba vegye az új nemzetközi kezdeményezéseket is. Természetesen ezen fontos célkitüzések eléréséhez biztosítani kell a megfelelő anyagi erőforrásokat is. Nagyon fontos, hogy a CITES hatékonysága elsősorban a felek általi teljes végrehajtáson múlik, legyenek e felek akár fogyasztók, akár termelők az érintett termékek tekintetében. A teljes végrehajtás a feleknek az Egyezményhez és annak alapelveihez való elkötelezettségén, a tudományos szakértelmen és vizsgálatokon, a kapacitásfejlesztésen és a kikényszerítésen múlik. Ennek alapján három fö stratégiai célkitüzést határoztak meg: az Egyezményhez és annak alapelveihez való elkötelezettséget, az Egyezmény müködéséhez és végrehajtásához szükséges anyagi erőforrások rendelkezésre bocsátását, valamint a CITES és más nemzetközi eszközök és eljárások által, a biodiverzitás csökkenési mértékének jelentős javítását és a kitüzött célok elérését. ${ }^{238}$

Az 1948-ban létrehozott Természetvédelmi Világszövetség mára az a világ legnagyobb és legösszetettebb környezeti hálózata lett. Az IUCN-ben képviselteti magát a kormányzati és közszektor, a magán- és a civilszféra is, egyedülálló erőforrásokat és szakértelmet állítva az emberi- és környezeti fejlődés, valamint a természetvédelem szolgálatába. Az IUCN-nek ezerháromszáz szervezet a tagja és mintegy tizenháromezer szakértőt tömörít, akik fajok túlélése, a környezetjog, védett területek, társadalmi és gazdaságpolitika, ökoszisztéma-gazdálkodás, oktatás és kommunikáció divízióiban fejtik ki tevékenységüket. $^{239}$ A CITES-sel összefüggésben az IUCN a fajok veszélyeztetettségére vonatkozó technikai mutatókat biztosítja, elsősorban a vörös lista és egyéb felmérések segítségével. A fajok széles körére vonatkozóan - elefánt, rinocérosz, tobzoska, tigris, medve, piton, skorpió, tengeri csikó, cikászok, orchideák, cápa, kaméleon - biztosít szakértelmet a CITES tudományos és technikai ülésein, beleértve az Állandó Tanács, a Növény és Állat Bizottságok találkozóit, valamint a részes felek konferenciáit. A legnagyobb hozzájárulás a Washingtoni Egyezményhez a TRAFFIC-el közösen elkészített vélemények és ajánlások, amelyeket az egyes függelékek kiegészítésének terveivel kapcsolatosan nyújtanak be. ${ }^{240}$

Megalakulása óta az IUCN több mint 1300 határozatot fogadott el. A Természetvédelmi Világkongresszushoz benyújtott indítványok és tervezetek természetvédelmi kérdések

238 CITES Strategic Vision: 2008-2020, https://cites.org/sites/default/files/eng/res/16/E-Res-16-03.pdf (2018. november 02.).

${ }^{239}$ IUCN About https://www.iucn.org/about (2019. 03. 09.).

${ }^{240}$ IUCN Our Work https://www.iucn.org/theme/species/our-work/sustainable-use-and-trade/cites (2019. 03. 09.). 
széles spektrumát fogják át és később ajánlás vagy határozat formájában kerülhetnek elfogadásra. A Világkongresszus keretében elfogadásra került határozat jellegü döntések elsősorban magát a szervezetet érintik, míg az ajánlások más ügynökségekhez, harmadik felekhez vagy a nemzetközi közösséghez szólnak. Mivel a határozatokat és a javaslatokat a gyakorlatban sok esetben nehéz megkülönböztetni egymástól, az IUCN kommunikációjában is tudatosan és nyíltan keveredik a két fogalom egymással. Az utóbbi évtizedekben a természetmegörzési törekvéseket jelentősen befolyásolták az IUCN döntései, a következő területeken: a globális természetvédelmi célkitűzések meghatározása; a nemzetközi környezetvédelmi jog fejlesztése; a sürgető kérdések azonosítása a természetvédelemben; speciális figyelmet érdemlő természetvédelmi kérdések azonosítása (például: tengerek, erdők, klímaváltozás). ${ }^{241}$

AZ IUCN nem mindennapos mértékü részvételét a CITES munkájában a Washingtoni Egyezmény teszi lehetővé, amely szavazati joggal nem rendelkező megfigyelőként biztosítja a „vadon élö állatvilág és növényvilág védelmében, megóvásában vagy gondozásában szakértelemmel rendelkezö minden olyan testület vagy ügynökség részvételét" a részes felek konferenciáján, amely részvételét a részes felek legalább egy harmada nem ellenzi. ${ }^{242}$ A nem kormányzati szektor nem csupán részt vesz a legtöbb bizottsági és egyéb ülésen, valamint konferencián, hanem már a kezdetektől jelentős erőforrásokat is invesztáltak a CITES szabályainak megvalósítása és a hatékony végrehajtás érdekében. Utóbbi többek között megnyilvánult egyes állami delegáltak részvételének finanszírozásában, a fajokra vonatkozó felmérések elkészítésében, kevésbé fejlett államokban hivatalos személyek és tisztviselők oktatásában, akár az illegális kereskedelemre vonatkozó saját nyomozások folytatásában. Egyes álláspontok ${ }^{243}$ szerint a nem kormányzati szektor közremüködése nélkül a CITES is a legtöbb vadvilággal kapcsolatos egyezmény, az

${ }^{241}$ The Impact of IUCN Resolutions on international conservation efforts, an overview. IUCN, 2018. 1-19. p. Elérhetö: https://portals.iucn.org/library/node/47226 (2019. 08. 05.).

${ }^{242}$ CITES, XI. cikk 7. pont

„Hacsak a Részes Felek legalább egyharmada nem ellenzi, a következő kategóriába tartozó, a vadon élő állatvilág és növényvilág védelmében, megóvásában vagy gondozásában szakértelemmel rendelkezö minden olyan testület vagy ügynökség részvételét lehetövé kell tenni, amely arról értesitené a Titkárságot, hogy a konferencia ülésszakain megfigyelökkel kívánja képviseltetni magát:

a) nemzetközi kormányközi és nem kormányközi ügynökségek vagy testületek, illetöleg nemzeti kormányügynökségek és testületek; és

b) olyan nemzeti nem kormányzati ügynökségek vagy testületek, amelyek részvételét jóváhagyta az az Állam, amelyben székhelyük van. Ha a részvételt lehetővé tették, e megfigyelök részvételi joggal rendelkeznek, szavazati joguk azonban nincs."

${ }^{243}$ TREXLER, M.C. - KOSLOFF, L.H.. The wildlife trade and CITES: an annotated bibliography for the Convention on International Trade in Endangered Species of Wild Fauna and Flora. Washington D.C. WWF, 1987. 
ismeretlenség sorsára jutott volna. Mivel a nem kormányzati szektort nem köti lojális megfontolás sem a kormányokhoz, sem a kereskedelmi érdekek képviselőihez, a természet- és állatvédelmi kérdésekkel kapcsolatosan szabadon fogalmazhatnak meg kritikai észrevételt vagy előtérbe helyezhetik az ökológiai megfontolásokat. Ez a felfogás nélkülözhetetlen hozzájárulást jelent az állami érdekek és a részes államokkal való jó kapcsolat, valamint a megőrzés elvei között egyensúlyozó Titkárság munkájához. ${ }^{244}$

Logikai megfontolásokból az Európai Unióhoz ${ }^{245}$ kötődő szervezetrendszeri kérdések, a tagállamok és az Európai Unió közötti feladatmegosztás e fejezet részeként kerül integrálásra.

A CITES-hez való csatlakozást követően minden, az Egyezményben részes államnak teljesítenie kell a nemzetközi szerződésből fakadó kötelezettségeit. Amennyiben egy állam egyben uniós tagállamnak minősül, akkor az uniós jogból fakadó kötelezettségeket is teljesíteni kell. Mivel az Európai Unió is részes fél az Egyezményben, az egész EU-nak fel kellett arra készülnie, hogy az ebböl fakadó feladatokat intézményi szinten rendezzék és azokat a gyakorlatban megvalósítsák. Így meg kellett határozni azt, hogyan osztják el a feladatokat az uniós és tagállami intézmények, szervek között.

Az Európai Unió szintjén megalapításra került a Tudományos Felülvizsgálati Csoport és a végrehajtási csoport, ezen túl az Európai Bizottságnak is vannak feladatai. Ugyancsak uniós szinten működik a vadon élö állat- és növényfajok kereskedelmével foglalkozó bizottság. Minden tagállamnak létre kellett hoznia az igazgatási és tudományos hatóságait és tagállami szinten is biztosítani kell a vadvilági rendeletek hatékony végrehajtását, a kikényszerítést. Az Európai Bizottság ellenőrzi az uniós vadvilág kereskedelmi rendeletek végrehajtását a tagállamokban, azokkal együttműködve. Az egyik legfontosabb feladata a Bizottságnak, hogy javaslatokat készítsen elő a CITES jogi szabályozásra vonatkozóan, és hogy végrehajtási rendelkezéseket alkosson. A Bizottság képviselője elnököl a bizottság, a Tudományos Felülvizsgálati Csoport és a végrehajtási csoport ülésein. A Bizottság segíti a tagállamok közötti és harmadik államokkal való kapcsolattartást. A Bizottság felügyeli, hogy a CITES konferenciákon az Európai Unió tagállamai közös álláspontot képviseljenek, azonban a 18. CoP-re vonatkozóan a végleges vélemény

\footnotetext{
244 Bövebben: FInger, MATTHIAS - PRINCEN, ThOMAS: Environmental NGOs in World Politics: Linking the Local and the Global. NGOs and CITES as a biodiversity regime. Routledge, New York, 2001.

${ }^{245}$ Az értekezés kéziratának lezárásakor, 2019 augusztusában, az Európai Uniónak 28 tagállama van, így az nincsen tekintettel az Egyesült Királyság kilépésének lehetőségére (várhatóan 2019 októberében).
} 
kialakítására a tanácsi munkacsoportokban és a részes felek konferenciájának ülésén került sor. ${ }^{246} \mathrm{~A}$ határozat indokolása szerint nem álltak a Bizottság rendelkezésére megfelelő időben azon dokumentumok és információk, amelyek lehetővé tették volna az álláspont kialakítását. „...A Bizottság rendszeres kapcsolatban áll azokkal az érdekelt felekkel, akik érintettek az egyezmény hatálya alá tartozó kérdésekben, például a környezetvédelmi nem kormányzati szervezetekkel, a vadon élö növényekböl és állatokból készült termékek kereskedelmével foglalkozó gazdasági ágazatok képviselöivel, valamint a vadászati vagy halászati szervezetekkel. 2019. január 29-én a Bizottság szolgálatai külön konzultációs találkozót tartottak az érdekelt felekkel a CITES CoP18 kapcsán megvitatandó kérdésekröl alkotott álláspontjuk megismerése érdekében. A javasolt tanácsi határozat kidolgozása során a Bizottság megfelelö módon figyelembe vette az érdekelt felek által szolgáltatott információkat. ... A CITES CoP18-hoz több munkadokumentum szintén nem állt elég korán a Bizottság rendelkezésére ahhoz, hogy jelen pillanatban javaslatot tudjon tenni az uniós álláspontra. A Bizottság ezért azt javasolja, hogy az e kérdésekkel kapcsolatos álláspontot a tanácsi munkacsoportban folytatott viták során, vagy a csak később elérhetővé váló dokumentumok esetében a felek konferenciájának ülésén alakitsák ki."247 Ugyanaz az indokolás szerepelt az előző, 17. konferenciával elfogadott uniós álláspont kapcsán is. „A CITES CoP 17 számos dokumentuma (különösen a munkadokumentumok; lásd e dokumentum II. mellékletének 1. pontját) nem állt kellö idöben a Bizottság rendelkezésére ahhoz, hogy jelen pillanatban javaslatot tudjon tenni az uniós álláspontra vonatkozóan. A Bizottság így azt javasolja, hogy az e kérdésekkel kapcsolatos álláspontok kialakitására a tanácsi munkacsoport megbeszélésein, a Bizottság értékelése alapján kerüljön sor." 248

A hatóságok első típusa, amelyek feladatokkal rendelkeznek, az igazgatási hatóságok (Managment Authority). Az Európai Unió vadvilági szabályozását alkotó rendeletek hatékony végrehajtása érdekében nélkülözhetetlenek a megfelelően felszerelt és felkészült igazgatási hatóságok léte a tagállamokban. Az igazgatási hatóságok feladatai nem

\footnotetext{
${ }^{246}$ JAVASLAT A Tanács határozata a veszélyeztetett vadon élő állat- és növényfajok nemzetközi kereskedelméröl szóló egyezmény részes felei konferenciájának 18. ülésén (CITES CoP18) az Unió nevében képviselendő álláspontról. COM(2019) 146 final, 2019/0083(NLE). Brüsszel, 2019. 03. 21. [Továbbiakban: $\operatorname{COM}(2019) 146$ final, 2019/0083(NLE)].

${ }^{247} \operatorname{COM}(2019) 146$ final, 2019/0083(NLE). 3. pont „Az Unió által képviselt álláspont”.

${ }^{248}$ JAVASLAT A Tanács Határozata veszélyeztetett vadon élő állat- és növényfajok nemzetközi kereskedelméről szóló egyezmény (CITES) részes felei konferenciájának a dél-afrikai Johannesburgban 2016. szeptember 24. és október 5. között megrendezendő 17. ülésére benyújtott bizonyos javaslatok tekintetében az Európai Unió által képviselendő álláspont meghatározásáról. COM(2016) 437 final, 2016/0200(NLE). Brüsszel, 2016. 07. 01. 5. pont „Egyéb elemek”.
} 
korlátozódnak az engedélyek és bizonylatok kiadására, azonban a humán erőforrás jelentős része erre a tevékenységre kerül alkalmazásra. Mivel szükséges, hogy különböző tagállamok igazgatási hatóságai kommunikálni tudjanak egymással, közös és megosztott számítógépesített rendszerek kerülnek kialakításra az egyes dokumentumok, éves jelentések kibocsátása és az elektronikus kapcsolattartás érdekében. ${ }^{249}$ Az Alap Rendelet minden tagállam számára előírja legalább egy igazgatási hatóság felállítását. ${ }^{250}$

Az elsődleges vagy egyetlen igazgatási hatóság képviselője ugyancsak képviseli a tagállamát az évente három-négy alkalommal összehívott bizottságban (Committee on Trade in Wild Fauna and Flora; a vadon élö állat- és növényfajok kereskedelmével foglalkozó bizottság). A bizottság megvitatja a vadvilági kereskedelemmel kapcsolatos legfontosabb kérdéseket és kialakítja az EU álláspontját, amelyet a CITES konferenciákon képviselnek. A bizottság elnöki posztját az Európai Bizottság látja el. ${ }^{251}$ A legutóbbi ülést 2018 szeptemberében tartották meg, ahol többek között napirendre tűzték a 2019-es évben esedékes, megrendezésre kerülő 18. részes felek konferenciájára való felkészülést. ${ }^{252}$ Az egyes tagállamok kialakíthatnak speciális részlegeket is az igazgatási hatóságokon belül, például amelyek a halászati vagy erdészeti kérdésekkel foglalkoznak.

Minden tagállamnak közzé kell tennie az igazgatási hatóság elérhetőségét. Magyarország tekintetében ez a Agrárminisztérium Biodiverzitás és Génmegőrzési Főosztálya. ${ }^{253}$

A második típusú hatóság, amelyet minden tagállamnak ki kell alakítania, az úgynevezett tudományos hatóság (Scientific Authority). Feladatainak az egyéb kijelölt igazgatási hatóságokétól függetlennek kell lennie. ${ }^{254}$ Minden tagállamnak legalább egy tudományos hatóságot kell felállítania. A tudományos hatóságok legalább egy tagja képviseli

\footnotetext{
${ }^{249}$ European Union Wildlife Trade Reulations. Refernce Guide. TRAFFIC 2017. június. 132. p. [Továbbiakban: Reference Guide, 2017.]

${ }^{250}$ A Tanács 338/97/EK rendelete (1996. december 9.) a vadon élő állat- és növényfajok számára kereskedelmük szabályozása által biztosított védelemröl (Alap Rendelet) 13. cikk (1) a) és b) „Valamennyi tagállam kijelöl egy igazgatási hatóságot, amely elsödlegesen felelös e rendelet végrehajtásáért és a Bizottsággal történö kapcsolattartásért. b) Valamennyi tagállam további igazgatási hatóságokat és más illetékes hatóságokat is kijelölhet a rendelet végrehajtásának céljából, ebben az esetben az elsödleges igazgatási hatóság feladata annak biztositása, hogy a többi hatóság valamennyi, e rendelet végrehajtásához szükséges tájékoztatást megkapjon." [Továbbiakban: Alap Rendelet]

251 The Committee on Trade in Wild Fauna and Flora. http://ec.europa.eu/environment/cites/ctwff_en.htm (2019. 04. 17.).

${ }^{252}$ Draft Agenda 83rd Meeting of the Committee on Trade in Wild Fauna and Flora. Brussels, Friday, 14 September 2018. https://circabc.europa.eu/sd/a/94fcffa4-5672-45e9-908c-a115a1832716/83_COM_agenda.pdf.

${ }^{253}$ Names and addresses of the Management and Scientific Authorities designated by the Member States 59. p. http://ec.europa.eu/environment/cites/pdf/list_authorities.pdf (2019. 04. 17.).

${ }^{254}$ Alap Rendelet 13. cikk (2) bekezdés.
} 
tagállamát a Tudományos Felülvizsgálati Csoport ülésein, tekintettel az éppen tárgyalt témakörre és az ahhoz szükséges speciális ismeretekre.

Minden hatóság tekintetében a tagállamok az EU-nak megadott adatokban bekövetkező valamennyi változást - legkésőbb e változások bekövetkeztét követő két hónapon belül közlik a Bizottsággal. ${ }^{255}$ A tudományos hatóságokon belül ugyanúgy lehetőség van speciális részlegek felállítására, ha azt a szakterület megkívánja. Több tagállamban külön növényvilággal és állatvilággal kapcsolatos hatóságok kerültek kialakításra, vagy a tudományos hatóságot különböző szakértőkből álló bizottságok alkotják. Utóbbi esetekben mindig meg kell határozni az elsődleges hatóságot és képviselőt az átláthatóság és hatékony kommunikáció biztosítása érdekében. ${ }^{256}$

A tudományos hatóságok megfelelő kialakítása a nemzetközi vadvilági kereskedelem akadálymentes lebonyolítása érdekében is nélkülözhetetlen, mivel a CITES egyik elfogadott határozata alapján a részes felek nem fogadhatnak el exportengedélyeket olyan államoktól, amelyek nem értesítették a Titkárságot tudományos hatóságukról, legalább két CoP között eltelt időtartam erejéig. ${ }^{257}$

Az uniós rendeletek, különösen az Alap Rendelet számos más feladat ellátását a tudományos hatóságokhoz utalja. A legfontosabb ezek közül, hogy az igazgatási hatóságot a tudományos hatóságnak kell segítenie mintegy harmincezer állat- és növényfaj lehetséges behozatalára vonatkozó döntésben. ${ }^{258}$ Magyarországon a tudományos testület feladatait a természetvédelemért felelős miniszter látja el. ${ }^{259}$

A Tudományos Felülvizsgálati Csoportot (Scientific Review Group, SRG) az Alap Rendelet hozta létre. A SRG valamennyi tagállam tudományos testületének vagy testületeinek képviselőiből áll, és elnöke a Bizottság képviselője. ${ }^{260}$ Az SRG minden évben háromnégy ülést tart Brüsszelben és megvitat minden olyan tudományos kérdést, amely az EU vadvilág kereskedelmi rendeleteihez kapcsolódik. Ugyancsak állást foglal, hogy a kereskedelem káros hatással rendelkezik-e a fajok megőrzésére. Fontos feladata, hogy a csoport véleményt alkot arról, hogy egy adott faj meghatározott államból történő behozatala találkozik-e a rendeletekben felállított követelményekkel. Azokban az esetekben, amikor az importkorlátozás a Bizottság által kerül elfogadásra, a SRG véleménye alapján, az

\footnotetext{
255 Alap Rendelet 13. cikk (3) bekezdés c) pont.

${ }^{256}$ Reference Guide, 2017. 133. p.

${ }^{257}$ Resolution Conf. 10.3 Designation and role of the Scientific Authorities 2.b.

258 Alap Rendelet 4. cikk A Közösség területére történő behozatal.

259 292/2008. (XII. 10.) Korm. rendelet a veszélyeztetett vadon élö állat- és növényfajok nemzetközi kereskedelmét szabályozó nemzetközi és európai közösségi jogi aktusok végrehajtásának egyes szabályairól. 2.§. ${ }^{260}$ Alap Rendelet 17. cikk (1) bekezdés.
} 
adott faj meghatározott államból történő behozatala tilos lesz. Az SRG véleményét a Bizottság a vadon élő állat- és növényfajok kereskedelmével foglalkozó bizottságnak is továbbítja. ${ }^{261}$

Jellemzően számos hatóság van egy-egy tagállamban, amely a rendeleteknek való megfelelés érdekében a végrehajtást ellenőrzi és felel a szabályok kikényszerítéséért. Ezek a vadvilági kereskedelem tekintetében lehetnek vám, rendőri vagy környezeti felügyeleti szervek és eljárások. A tagállamok igazgatási hatóságai ellenőrzik az Alap Rendeletben szereplő előírások betartását. Amennyiben az illetékes hatóság bármikor úgy véli, hogy sérül az elöírások betartása, megteszi a szükséges lépéseket a jogsértések megszüntetésére vagy jogi beavatkozást kezdeményez. ${ }^{262}$

Az Alap Rendelet elöírja egy végrehajtási csoport (Enforcement Group) létrehozását is, amely valamennyi tagállam képviselőjéből áll és feladata, hogy rendeletben foglalt elöírások megvalósuljanak. A csoport elnöke a Bizottság képviselője. ${ }^{263}$ A csoport feladata, hogy figyelemmel kísérje a tagállamok végrehajtási politikáját és gyakorlatát, valamint ajánlásokat tesz a vadvilág kereskedelmi szabályozás fejlesztésére. Ezen túl a tagállamok közötti információcserét is segíti a vadvilág kontrollra vonatkozó gyakorlatra, szaktudásra vonatkozóan. ${ }^{264}$

A fentiekből is látszik, hogy a CITES hatékony nemzeti szintü végrehajtása és az Egyezményből fakadó kötelezettségek teljesítése érdekében, a részes feleknek számos intézményi, szervezeti követelménynek kell megfelelniük. Azonban nem elégséges pusztán a szervezeti keretek biztosítása, hanem megfelelő szakképzettséggel rendelkező humán erőforrásról is gondoskodni kell, olyan tisztekről, akik képesek azonosítani és felismerni a védett fajokat, azokból készült termékeket. Sok államban - ahogy az értekezés több pontján is utaltam erre - éppen a szaktudás hiánya okoz az Egyezménynek való megfelelési problémákat, így akár a vámszervek, akár az igazságszolgáltatási szervezetrendszer szintjén. Amikor az Európai Unió részes féllé vált az Egyezményben, ki kellett alakítani a különböző szinteken müködő szervek és hatóságok rendszerét is, továbbá a részes felek konferenciáján képviselt álláspontok kialakításának rendjét.

\footnotetext{
${ }^{261}$ Reference Guide, 2017. 135. p.

${ }^{262}$ Alap Rendelet 14. cikk (1) bekezdés a) és b) pontok.

${ }^{263}$ Alap Rendelet 14. cikk (3) bekezdés a) pont.

${ }^{264}$ Enforcement Group. http://ec.europa.eu/environment/cites/eg_en.htm (2019. 03. 03.).
} 


\section{IV.3. A vadvilági kereskedelmet szabályozó nemzetközi egyezmény kritikai vizsgálata}

„A CITES-nek problémái akadnak, amikor magas kereskedelmi értékü fajokkal foglalkozik."265

Bár a CITES-t az egyik legsikeresebb nemzetközi egyezménynek tekintik, az elmúlt évtizedek során több területen is jelentős kételyek merültek fel. A vadvilág védelme érdekében hozott rendelkezések esetében különösen fontos a kritikai szemlélet, hiszen csak így ismerhetők fel azok gyakorlati hatásai, és a hibákból tanulva fejleszthetők tovább. A multilaterális környezeti egyezmények körében a CITES speciális helyet foglal el, hiszen elsődleges célja a kereskedelem szabályozása. Azonban az elmúlt időszak bebizonyította, hogy az egyezmény az elsődleges eszköz a vadvilággal kapcsolatos büncselekmények és az illegális kereskedelem elleni harcban is.

A CITES kritikai szemléletü vizsgálata magában foglalja a következö részterületeket:

1. az Egyezmény elfogadását követően felmerült úgynevezett „történeti” problémák és a hatékonyság kérdése;

2. az egyes fajok besorolása a CITES különböző függelékeibe és annak hatása az orvvadászatra;

3. fenntartások hatása az egyezmény szabályainak valódi érvényesülésére;

4. a CITES érvényesülése a részes felek államaiban, a hatékonyság kérdése és az Egyezmény szabályainak való megfelelés;

5. a CITES és WTO szabályainak összeegyeztethetősége, különös tekintettel a kereskedelmi felfüggesztésekre.

Természetesen nem mondhatjuk, hogy a CITES önmagát egy tökéletesen müködő rendszerként aposztrofálná. A részes felek konferenciáin újra és újra határozatokban célozzák meg azokat a fontos kérdéseket, amelyek akadályozzák az Egyezmény érvényesülését.

Főtitkári visszatekintésében John E. Scanlon ${ }^{266}$ úgy fogalmazott, hogy amikor 2010 elején elfoglalta a CITES főtitkári posztját, mind a magas szintű politikai támogatás, mind a

265 Jeff Rotman, WWF, www.naturepl.com Idézet forrása: http://news.bbc.co.uk/2/hi/science/nature/8606011.stm (2019. 07. 20.) „CITES...gets into difficulty when it tries to deal with species of high commercial value.”

${ }^{266}$ John E. Scanlon (Ausztrália) 2010 és 2018 között töltötte be a CITES fötitkári pozícióját. 
megfelelő finanszírozás hiányzott az Egyezmény mögül. Továbbá számos végrehajtási probléma volt felismerhető, a Titkárság legfontosabb kapcsolati hálói szakadozottak voltak, miközben szembe kellett nézni a vadvilágot károsító büncselekmények és az illegális kereskedelem negatív konzekvenciával, különösen az elefántcsont és a rinocéroszszarv tekintetében. Megfogalmazásában az elmúlt csaknem egy évtizedben a nemzetközi közösség ,újra felfedezte” a CITES-t és számos területen elörelépés történt. Ezek a következőket foglalják magukban:

- a szélesebb hallgatóság elérése;

- a vadvilági illegális kereskedelem természetének, mértékének, hatásainak felismerése és annak súlyos büncselekményként kezelése;

- az illegális kereskedelem elleni harc közös felelősségként való kezelése;

- a CITES hozzákapcsolása a fenntartható fejlődési célkitűzésekhez;

- magas szintü politikai elismertség szerzése a CITES-nek;

- ENSZ Vadvilág Világnap bevezetése (UN World Wildlife Day)

- további CITES-hez csatlakozó részes felek; ${ }^{267}$

- a CITES nem kereskedelemet támogató vagy ellenző, hanem a szabályozott kereskedelem mellett áll;

- az elkobzott elefántcsont és rinocéroszszarv megsemmisítésének kérdése;

- közvetlen kommunikáció egyéb résztvevőkkel, mint a nem kormányzati szervezetek köre;

- a helyi közösségek elérése;

- magas szintü és szervezett részes felek konferenciái;

- új tengeri és fafajok felvétele a CITES listákra;

- a technológia szolgálatba állítása, a hatékony végrehajtás érdekében;

- új finanszírozási források;

- Titkárság reformja. ${ }^{268}$

\footnotetext{
2672010 és 2018 között a CITES részes feleinek száma 175-röl 183-ra nőtt.

${ }^{268}$ John. E. Scanlon: Early reflections on eight years as Secretary-General of CITES, 2010-2018 (2018. 04. 13.).

https://www.linkedin.com/pulse/early-reflections-eight-years-secretary-general-cites-scanlon-am/ (2019. 01. 27.).
} 


\section{IV.3.1. Kezdeti problémák és a hatékonyság kérdése}

A veszélyeztetett fajok kereskedelméről szóló egyezménnyel szemben felhozott ún. „történeti” jellegü problémák között első helyen szerepel a terminológiai bizonytalanság, ami nem csak az értelmezést nehezíti, hanem a nemzeti szintü átültetésben és végrehajtásban is problémákhoz vezet. Az olyan kifejezések, min a ,faj, a „példány”, a „,könnyen felismerhető része vagy származéka”, az „elsődlegesen kereskedelmi célzatból” különösen félreérthetőnek tekintők. Utóbbiak közül az Egyezmény értelmező rendelkezési között megtalálható a ,faj” és a ,példány” meghatározása. ${ }^{269}$ Azonban a ,faj” fogalma figyelmen kívül hagyja azt a tényt, hogy egyes fajok nagy számú populációban élnek bizonyos államokban, míg más ország területén már a kihalás szélére sodródtak. Sőt, a nagyobb kiterjedésű államok esetében, az országon belül fellelhető populációk között is nagy különbségek lehetnek. ${ }^{270}$ A szövegezés és a kifejezések által felvetett problémákat legtöbb esetben a részes felek konferenciáin elfogadott határozatokkal igyekeztek orvosolni. Így 1994-ben, a 9. CoP-n került meghatározásra, mit kell a „könnyen felismerhető része vagy származéka" kifejezés alatt érteni. ${ }^{271}$ A kezdeti időszakok további gondja volt az egyes fajok populációjának megosztott függelékekbe sorolása, vagyis ugyanannak a fajnak különböző populációit eltérő függelékekbe sorolják, a releváns vizsgált populáció adott államban való helyzete szerint. ${ }^{272}$ Különös hangsúllyal merült fel ez a problémakör az afrikai országok elefánt-állománya kapcsán, ahol bizonyos egyedszám vadászatát engedélyezték minden évben és az így befolyt összegeket fajmegőrzési és közösségfejlesztési kiadásokra fordították. ${ }^{273} \mathrm{Az}$ afrikai elefántok példáját több esetben is használhatjuk a CITES-el kapcsolatos kritikai észrevételek alátámasztására. Az értekezés későbbi fejezetében részletesen elemzem, hogy az egyes függelékekbe való sorolás milyen hatással lehet a fajmegőrzési erőfeszítésekre.

Kritika érte a részes államokat abban a tekintetben is, hogy a listára vétel és a védelem tekintetében is előtérbe helyezik az „ölelnivaló állatokat” és a „szép madarakat”.

\footnotetext{
${ }^{269}$ CITES, I. cikk, Meghatározások: „a ,,faj” bármely fajt, alfajt vagy ezek földrajzilag elkülönült populációját jelenti”.

270 MCOMBer, Elizabeth M.: Problems in Enforcement of the Convention on International Trade in Endangered Species. Brooklyn Journal of International Law, Vol. 27. Issue 2. 2002. 690. p. [Továbbiakban: MCOMBER, 2002.].

${ }^{271}$ Conf. Res. 9.6. (Rev. CoP 16) Trade in readily recognizable parts and derivatives.

${ }^{272}$ A megosztott listára vételt nevezik az angol terminológiában ,split-listed” eljárásnak.

${ }^{273}$ MCOMBER, 2002. 695. p.
} 
Általában a legkritikusabb helyzetben lévő fajok „,kevésbé lenyügözők”. ${ }^{274}$ Különösen igaz volt az előbbi megállapítás az 1990-es évek elején, amikor a listára vétel tekintetében háttérbe szorultak egyes növényfajok, illetve azok sokkal kevesebb figyelmet kaptak. Ennek alapján olyan ajánlások kerültek megfogalmazásra, mint a II. Függelékben szereplő növényfajok felülvizsgálata: melyik sorolható a veszélyeztetett kategóriába és pontos, állami szintén készülő statisztikák vezetése a kereskedelem mértékről. Továbbá, megfogalmazásra került az állami végrehajtó szervek, különösen a vámszervek ellenőreinek továbbképzése, a CITES rendelkezések megsértése esetén, állami szinten kiszabható bírságok és büntetések súlyosbítása. ${ }^{275}$

A nem részes fél államokkal való kereskedelem engedélyezése az Egyezmény elfogadásának első percétől kezdődően éreztette a negatív hatását. Még az 1990-es években is a globális kereskedelem mintegy harminc százaléka, vagyis csaknem harmada ilyen államokkal történt. Bár a CITES meghatároz bizonyos garanciákat a nem részes államokkal történő kereskedelem tekintetében, sok esetben a kevésbé fejlett országokban hiányoztak az „illetékes hatóságok”, amelyek ki tudták volna állítani a megfelelő iratokat és engedélyeket. ${ }^{276}$ Bár a felsorolt gondok megoldódni látszanak az Egyezmény tagságának univerzálissá válásával, a megfelelő erőforrásokkal rendelkező hatóságok és az adminisztratív terhek hiányos ügyintézése, éppúgy a szakértelem hiánya, mind a mai napig akadályozza a CITES rendelkezéseinek végrehajtását, a védelem magas szintjét.

A gyakorlatban számos egyéb olyan probléma merül fel, amely nem kifejezetten a CITES megfogalmazásából vagy a kereskedelem szabályozásából adódik, azonban nehezíti, vagy a múltban megnehezítette a részes államokban való hatékony végrehajtást. Utóbbi kérdéskörök egy részét a részes felek konferenciáin igyekeztek orvosolni. Az említett problémákhoz tartoznak nevezetesen az állami végrehajtó, különösen a vámszervek tisztviselőinek és ellenőrzőinek alulképzettsége a fajazonosításban, a szervek erőforráshiánya, valamint az egyes fajok listára való besorolása tekintetében jelentős gondokat okozott az egységes nomenklatúra hiánya.

1973-as megalkotása óta az Egyezményt folytonos módosításokkal és kiegészítésekkel igyekeztek úgy alakítani, hogy megfeleljen az újabb kor követelményeinek és a változó

\footnotetext{
${ }^{274}$ BURNS, WILLIAM C.: CITES and the Regulation of International Trade in Endangered Species of Flora: A Critical Appraisal, 8 Dick. J. Int'l L. 203 (1990) 215. p. [Továbbiakban: BuRNS, 1990.].

${ }^{275}$ BURNS, 1990. 215-223. p.

${ }^{276}$ LIWO, KARL JONATHAN: The Continuing Significance of the Convention on International Trade in Endangered Species of Wild Fauna and Flora during the 1990s, Suffolk Transnational Law Journal Vol. 15. No. 1. (Fall, 1991.) 139-140. p.
} 
kihívásoknak. Azonban, bár sokan tekintik a CITES-t az egyik leghatékonyabb nemzetközi rendszernek, mások számos kritikai észrevételt fogalmaztak meg vele szemben.

Elsősorban a CITES funkcionális hatékonyságával szemben merülnek fel aggályok, amelyek főként a nemzetközi közösségnek a vadvilág megőrzésére vonatkozó eltérő elképzeléseiből, az eltérő hangsúlyokból, a fogyasztás vagy a fenntarthatóság előtérbe helyezéséből, valamint a hatékony megértés és megegyezés hiányából fakadnak. Minden kétséget kizáróan az Egyezmény valódi előrelépés volt és valószínüsíthetően a vadvilág megőrzése körében született nemzetközi egyezmények közül az egyik legfontosabb. Azonban a szkeptikusok a kritikák legszélsőségesebb formáit fogalmazzák meg vele szemben, amelyeket egy olyan korszakban, amikor a biológiai sokféleség csökkenése ellen folytatott harc a nemzetközi közösség prioritása, nem lehet figyelmen kívül hagyni. A kritikusok álláspontja szerint az Egyezmény nem találkozik az új évezred és a XXI. század követelményeivel, ezért új megközelítés szükséges a tárgykörben. A „zöld” nem kormányzati szervezetek részéről főleg az egyes fajok függelékekbe való felvételével, ${ }^{277}$ valamint egyes, az Egyezmény végrehajtásáért felelős személyek korrupcióban való részvételével szembeni fellépés hiánya miatt fogalmaztak meg ellenvetéseket. Így egyes ellenzők ${ }^{278}$ szerint az Egyezmény számos problémával küzd. A legszélsőségesebb álláspontok szerint a CITES elbukott, és a későbbiekben egyáltalán nem kellene támogatni azt. Erre példa a „Friends of the Orangutans” malajziai szervezet petíciója, amely szerint a CITES teljes bukás. Példaként hozzák fel, hogy néhány lépésre a CITES bangkoki irodája mellett van egy piac, ahol minden vasárnap vadvilági termékeket árulnak immáron 20 éve, egy olyan területen, ahol a kereskedelmi tevékenység elvileg a CITES alapján került szabályozásra. ${ }^{279}$ Az ellenzők másik tábora a gazdasági és szociális fejlődés, a nemzeti szuverenitás védelme és a hagyományok tisztelete, a profit maximalizálása és a bürokratikus

\footnotetext{
${ }^{277}$ Ilyen bukásnak tekintették, amikor 2013-ban a jegesmedvéket nem sikerült az I. Függelékbe felvenni, annak ellenére, hogy az őslakosok vadászathoz való jogát nem érintette volna a módosítás. Az érintett államok közül egyedül Kanada engedélyezi a jegesmedvék sportvadászatát és nemzetközi kereskedelmét. See: Animal Welfare Institute, CITES CoP 16. Successes and failures. https://awionline.org/awi-quarterly/2013-spring/cites-cop16-successes-and-failures (2019. 02. 16.).

${ }^{278}$ A negatív vélemények főként az egyes fajok függelékekbe sorolásához kapcsolódva kerülnek előtérbe, a részes felek konferenciái után. Főként, mivel sokszor gazdasági hasznuk miatt nem kerülnek magasabb védelmi szintet biztosító átsorolásra, az érdekelt államok ellenszavazata eredményeképpen. Például: Mark Jones (Care for the Wild International, UK): a CITES a politikai célokat szolgálja. (Mark Jones: Has CITES had its day? 2010., BBC http://news.bbc.co.uk/2/hi/science/nature/8606011.stm). Továbbá: CITES members silent over failure to address illegal toothfish fishing. 2013. (https://www.traffic.org/news/cites-members-silent-over-failure-to-address-illegal-toothfish-fishing/) De a kérdések az elefántcsontkereskedelem kapcsán is felmerültek: VANDEGRIFT, JOSEPH: Elephant Poaching: CITES failure to combat the growth in chinese demand for ivory. In: Virginia Environmental Law Journal Vol. 31, No. 1 (2013), pp. 102-135. ${ }^{279}$ Stop Funding CITES - They Are Part of the Problem Not the Solution. https://www.change.org/p/stopfunding-cites-they-are-part-of-the-problem-and-not-the-solution\#petition-letter.
} 
kontroll minimalizálása tekintetében hozza fel érveit. Az egészen biztos, hogy a valamennyi tábort alapvetően nem csupán a reális megfontolás vezeti, hanem az érzelmek és személyes meggyőződés által irányított érveket is felsorakoztatnak. A legszélsőségesebbek a vadvilágból származó termékek kereskedelmének teljes liberalizálása mellett foglalnak állást, mivel meggyőződésük, hogy a tilalmak csak a feketepiac megerősödéséhez vezetnek. Ami minden oldal számára megfelelő megoldás lehetne, az a CITES határozottabb, hatékonyabb, előrelátóbb végrehajtása. Az Egyezménnyel kapcsolatosan meg lehet fogalmazni azt a kritikai észrevételt, hogy bár elfogadásának időszakában a veszélyeztetett fajokat érintő kereskedelmi tevékenység nagyon súlyos károkat okozott, ahogyan ma is, de emellett az utóbbi időszakban a biológiai sokféleség radikális csökkenésének elsődleges oka a természetes élőhelyek pusztítása. Így a jelenlegi szabályozás ún. „top-down” szisztémát követ. Helyette előnyösebb lenne ennek ellenkezője, vagyis a probléma gyökereit, az alapokat kezelő rendszer. Egyes álláspontok szerint a jelenlegi parancsoló-kontrolláló (command-and-control) rendszer helyett elönyösebb lenne egy elkötelezettségen és engedményeken alapuló rendszer kiépítése. Mindenesetre a biodiverzitás csökkenése ellen tett eddigi erőfeszítések és az ezzel kapcsolatos klasszikus felfogás helyett a nemzetközi közösségnek új irányvonalakat kellene kijelölnie, és követnie, amely az értékek sokféleségének elismerésén és egy kiegyensúlyozott rendszeren nyugszik. ${ }^{280}$

A CITES-el szemben már elfogadásától kezdődően kritikai észrevételeket fogalmaztak meg. Ha végig tekintünk az Egyezmény négy évtizedes történetén, akkor ráeszmélhetünk, voltaképpen minduntalan ugyanazon problémakörök akadályozzák annak hatékony érvényesülését. Visszatérő gondok adódnak az államok adminisztratív szervezetrendszerével, a megfelelő szaktudás hiányával, a kikényszerítés alacsony fokával. További negatív hatások adódnak a fajok függelékekbe való sorolásával, egyes különösen veszélyeztetett és a szabályozás szempontjából kiemelt fajok - mint az afrikai elefántok - populációjával kapcsolatos bizonytalanságokból, az államok egyet nem értéséből. Végül, de nem utolsó sorban országok gazdasági szektorainak lobbija nagy hatással van a részes felek álláspontjának kialakításában. Összességében megállapítható, hogy már a kezdeti, ún. „történeti" problémák és a hatékonysággal kapcsolatos kérdések is mind két dologra, az egységes állami akarat és az országokban rendelkezésre álló erőforrások hiányára vezethetők vissza.

${ }^{280}$ Bowman, MichaEl: A Tale of Two CITES: Divergent Perspectives upon the Effectiveness of the Wildlife Trade Convention. Review of European Community \& International Envi-ronmental Law Vol. 22 (3) (2013). 228-238. p. 


\section{IV.3.2. A CITES szabályozási rendszere - a Függelékekkel kapcsolatos problémák feltárása egy esettanulmányon keresztül}

A részes felek konferenciájának feladata az I. és II. Függelékek módositása, az Egyezmény XV. Cikke alapján. A módosításra lehetőség van a részes felek konferenciáján, vagy a konferenciák közötti időszakban is.

A részes felek konferenciájához kapcsolódóan a Függelékek módosítását bármely részes fél javasolhatja. A módosítás javasolt szövegét az ülésszak előtt legalább 150 nappal közölni kell a Titkársággal. A módosítási javalatról a Titkárság konzultál a többi részes féllel és az érintett CITES testületekkel, majd a választ valamennyi részes féllel közli, az ülésszak elött legalább 30 nappal. A Függelékekben javasolt módosításokat a jelenlevő és szavazó részes felek kétharmados többségének kell elfogadnia. A szavazás szempontjából a jelenlevő, és igennel vagy nemmel szavazó részes feleket kell figyelembe venni. A szavazástól tartózkodó részes felek nem számíthatók be a módosítás elfogadásához szükséges kétharmadba. Az ülésszakon elfogadott módosítások az ülésszak után 90 nappal lépnek érvénybe valamennyi részes fél tekintetében, kivéve, ha fenntartással élnek. ${ }^{281}$

Az I. és II. Függelékek módosítására az ülésszakok közötti időszakban is lehetőség van. Bármely részes fél kezdeményezheti a Függelékekbe sorolt fajok felülvizsgálatát, ilyenkor ún. „postai úton” történő, vagyis alapvetően írásbeli eljárás történik. Az Egyezmény különválasztja a tengeri fajokra és a nem tengeri fajokra vonatkozó módosításokat. A tengeri fajok esetében a módosítási javaslatokat a Titkárság azonnal közli a részes felekkel és konzultál a vonatkozó kormányközi testületekkel is. A konzultáció eredményét és a Titkárság saját álláspontját közli a részes felekkel. A tengeri fajokon kívül eső bármely más faj esetében a kormányközi testületekkel folytatott konzultáció nem része a módosítási eljárásnak. A részes felek a Titkárság értesítésének kézhezvételétől számított 60 napon belül közölheti észrevételeit. A beérkezett válaszokat és saját javaslatait a Titkárság közli a részes felekkel. Amennyiben az utóbbiak közlésétől számított 30 napon belül nem érkezik be kifogás, a módosítás 90 nap múlva lép hatályba, kivéve, a fenntartást bejelentő államokat. Amennyiben a javasolt módosításokkal kapcsolatosan kifogás érkezik a Titkársághoz, azt szavazásra kell bocsátani, amely ugyancsak írásbeli úton történik. A Titkárság értesíti a részes feleket, hogy kifogásról szóló értesítést kapott. Ezen értesítéstől számított 60 napon belül a részes felek igenlő szavazatokat, ellenszavazatokat és

${ }^{281}$ CITES XV. cikk (1) bekezdés (a)-(c) pontok. 
tartózkodást küldhetnek. Amennyiben valamilyen reakció a részes feleknek legalább a felétől nem érkezik be, a javasolt módosítást a következő konferenciára kell utalni, tárgyalás és szavazás céljából. Ha a szavazatok a részes felek legalább felétől beérkeznek, a módosítást az igennel vagy nemmel szavazó részes felek kétharmados többsége fogadja el. A szavazás eredményéről a Titkárság valamennyi részes felet értesíti. Amennyiben a módosítást elfogadják, a Titkárság által küldött értesítés keltétől számított 90. napon lép hatályba a módosítás, kivéve, ha a felek fenntartással élnek. ${ }^{282}$

A III. Függelék módositása egyszerübb eljárás keretében történik, hiszen az nyújtja a legcsekélyebb védelmet a listára vett fajok tekintetében. Bármelyik részes fél bármikor jegyzéket juttathat el a Titkársághoz azon fajokról, amelyeket a saját joghatósága területén a III. Függelékbe tartozónak tekint. A III. Függelék azoknak a részes feleknek a nevét tartalmazza, amelyek javasolták az érintett fajok III. Függelékbe való felvételét, a javasolt fajok tudományos nevét és egyéb, az Egyezmény szempontjából fontos vonatkozó adatokat. A jegyzék előterjesztésekor a Titkárság rendelkezésére kell bocsátani a kérdéses faj védelmére vonatkozó belföldi szabálymódosítást, minden egyéb a Titkárság által igényelt dokumentummal egyetemben. Amennyiben a III. Függelék módosításáról jegyzék érkezik a Titkársághoz, azt azonnal közlik a részes felekkel. A jegyzék a III. Függelék részeként lép hatályba, a közlést követő 90 nap múlva. A III. Függelékkel kapcsolatosan is lehetőség van fenntartás bejelentésére. A III. Függelékben felvétel céljából bejelentető részes fél, azt bármikor visszavonhatja úgy, hogy erről értesítést küld a Titkárságnak, amely közli a visszavonást valamennyi részes féllel. A visszavonás az ilyen közlés keltétől számított 30 . napon lép hatályba. ${ }^{283}$

Más szabályok vonatkoznak az Egyezmény módositására, így az elkülönül a Függelékekbe sorolt fajok jegyzékének módosításától. Az Egyezmény módosítását a részes felek legalább egyharmadának írásban kell kezdeményeznie. Ebben az esetben a Titkárság köteles a rendkívüli ülésszak összehívására, amely megvitatja és szavaz a módosításokról. Minden módosítás javasolt szövegét a Titkárságnak legalább 90 nappal a tanácskozás előtt valamennyi részes félhez el kell juttatnia. Az Egyezmény módosításait a jelenlévő és szavazó részes feleknek kétharmados többséggel kell elfogadnia. A szavazástól tartózkodó részes felek nem számítanak be a módosítás elfogadásához szükséges többségbe. A módosítás az azt elfogadó részes felek tekintetében 60 nappal azután lép hatályba, hogy a részes felek kétharmada a letéteményes kormánynál letétbe helyezte a módosítás

${ }^{282}$ CITES XV. cikk (2) bekezdés (a)-(1) pontok.

${ }^{283}$ CITES XVI. cikk (1)-(4) bekezdések. 
elfogadására vonatkozó okiratot. Ezt követően a módosítás minden további részes fél tekintetében 60 nappal azután lép hatályba, hogy ez a részes fél a módosítást elfogadó okiratát letétbe helyezte. ${ }^{284}$ Az előbbiek alapján egyértelmü, hogy az Egyezmény módosítására kizárólag rendkívüli ülésszakon van lehetőség. Éppen ezért is kérdőjelezték meg a CoP-ken elfogadott egyéb döntések kötelező mivoltát.

A CITES különböző függelékei eltérő védelmet biztosítanak az oda sorolt fajoknak, így a kereskedelem kontrollja is különböző szintü. Az afrikai elefántok példáján keresztül jól szemléltethető, hogy az egyes fajok CITES függelékekbe való besorolása hogyan befolyásolja az orvvadászatot és az illegális kereskedelmet. Bár az utóbbi években a részes felek igyekeztek új programokat kidolgozni az afrikai elefántok populációjának rehabilitálása érdekében, az eddigi, alapvetően politikai indokok által irányított döntéshozatal már helyrehozhatatlan károkat okozott és egyéb gazdasági, kulturális kérdéseket is felvetett. Az orvvadászat sokkal nagyobb szerepet játszik az elefántpopuláció csökkenésében, mint a biodiverzitás csökkenésének második indoka, az ún. élőhelypusztítás. Az 1980-as években az elefántok száma drasztikusan csökkent Afrikában, elsősorban az elefántcsontért való orvvadászatnak köszönhetően. Pontos mutatószámok nem állnak rendelkezésre, az óvatos becslések alapján az 1980-as 1.2 millió egyedszám mintegy 600 ezerre esett vissza 1989-re. Kenyában kétharmaddal, Zambiában és Tanzániában háromnegyeddel csökkent az elefántpopuláció. Az egyedszám zuhanórepülését egyaránt okozta az elefántcsont legális és illegális kereskedelme, amelyet felgyorsított az érintett országok bizonytalan gazdasági struktúrája, a politikai korrupció és az automata gépfegyverekhez való könnyebb hozzáférhetőség. ${ }^{285}$

A részes felek már 1983-ban elkezdtek foglalkozni az afrikai elefántok kérdésével és a gaboron-i konferencián elfogadásra került a Conf. 4.14 határozat, felkérve a Technikai Bizottságot, hogy dolgozzanak ki irányelveket az elefántcsont-kereskedelemre. 1985-ben az Argentínában tartott konferencián új határozatot fogadtak el, amely elöírta, hogy az afrikai államok határozzanak meg exportkvótákat a nyers elefántcsontkereskedelmére, így korlátozva a levadászott elefántok számát. Ekkor az afrikai elefántok a CITES Egyezmény II. Függelékében kaptak helyet. ${ }^{286}$

\footnotetext{
${ }^{284}$ CITES XVII. cikk (1)-(3) bekezdések.

285 HUNTER, DAVID - SALZMAN, JAMES - ZAELKE, DURWOOD: International Environmental Law and Policy. 5. kiadás University Casebook Series, Founation Press, St. Paul, USA, 2015. 1108-1109. [Továbbiakban: HUNTER-SALZMAN-ZAELKE, 2015.].

${ }^{286}$ Trade in Ivory from African Elephants. https://cites.org/sites/default/files/eng/cop/05/doc/E05-22.pdf (2019. 01. 23.).
} 
Néhány évvel később az 1989-es lausanne-i konferencia egyik fő problémája volt az afrikai elefántpopuláció csökkenése, az elefántcsont-kereskedelem és az elefántok I. Függelékbe való áthelyezésének lehetséges következményei. A tárgyalások eredményeként több munkadokumentum került elfogadásra, különösen az alábbi témakörökben: az elefántcsont-kereskedelmi kontrollrendszer hatékonyságának növeléséről, az akkor raktáron lévő elefántcsontról és legfőképpen a kereskedelmi szabályozás változásának hatásairól. $^{287}$

A függelékekbe való besorolással kapcsolatosan meg kell jegyezni, hogy a legmagasabb szintű védelmet biztosító I. Függelékbe sorolt fajok kereskedelme sem esik teljes tilalom alá. Kivitelezhető, ha nem elsősorban kereskedelmi célzatból történik, valamint előzetes engedélyhez van kötve.

A legmagasabb szintü védelmet és így a legszigorúbb szabályokat követelö I. Függelék tekintetében a kereskedelmet a fajok további fennmaradásának veszélyeztetésének megakadályozása érdekében különösen szigorúan kell szabályozni. A kereskedelmet csak rendkívüli körülményei között szabad engedélyezni. ${ }^{288}$ A kivitelhez exportengedély elözetes megadása és bemutatása szükséges. Az exportengedély kiadásához a kivitel helye szerinti állam Igazgatási Hatósága meggyőződik a példány beszerzésének jogszerü voltáról és a szállítás megfelelő körülményeiről. A Tudományos Hatóság meggyőződik az exportnak a faj további fennmaradására gyakorolt hatásairól. Az exportengedély kiadásához szükséges az importengedély megadása is. ${ }^{289} \mathrm{~A}$ bevitel helye szerinti állam Tudományos Testülete kiállíthatja az importengedélyt, de csak abban az esetben, ha a példányt nem elsödlegesen kereskedelmi célzatból használják fel, és ha a bevitel nem hátrányos a faj fennmaradására, valamint az élő példányok tartásához megfelelő feltételek állnak fent. Az I. Függelékbe sorolt fajok behozatalához szükséges az importengedély, az exportengedély vagy re-export bizonyítvány előzetes megadása és bemutatása. ${ }^{290}$ Az újrakivitel kizárólag re-export bizonyítvány alapján lehetséges, amelyek a re-exportáló állam Igazgatási Hatósága állíthat ki. A Hatóságnak meg kell győződnie arról, hogy az bevitel is a CITES szabályokkal összehangban történt meg. ${ }^{291}$ Az Egyezmény külön szabályozza az egyes fajok tengerről történő bevitelhez szükséges eljárást, amely a beviteli állam

\footnotetext{
${ }^{287}$ Agenda and working documents https://cites.org/eng/cop/07/doc/index.php (2019. 01. 23.)

${ }^{288}$ CITES II. cikk (1) bekezdés.

${ }^{289}$ CITES III. cikk (2) bekezdés a) - d) pontok.

${ }^{290}$ CITES III. cikk (3) bekezdés a) - c) pontok.

${ }^{291}$ CITES III. cikk (4) bekezdés a) - c) pontok.
} 
igazgatási hatóságának előzetes bizonylatán és a Tudományos Testület állásfoglalásán alapszik. $^{292}$

Ennek megfelelően, ha az afrikai elefántok az I. Függelékben helyezkednek el, nem lehetséges a nyers vagy megmunkált elefántcsont kivitele, amennyiben a másik országba történő bevitel célja az elefántcsont, vagy az abból készül termékek későbbi értékesítése. Ugyanakkor a kereskedelmi tevékenységgel összefüggésben csak az import van megtiltva, az export nem. Ezért az Egyezmény nem akadályozza meg a trófeák, szuvenírek és a tudományos minta kivitelét az országból, még ha az kereskedelmi célzattal történne is. ${ }^{293}$ A tárgyalások során számos afrikai állam, különösen Afrika déli részéröl, ellenérveket sorakoztatott fel az afrikai elefántok I. Függelékbe való áthelyezése ellen. Különösen az állami jövedelem nagymértékü csökkenését vetítették előre, valamint azt, hogy amint megtörténik a függelékváltás, a tapasztalatok alapján az afrikai elefántok várhatóan sohasem fognak visszakerülni az II. Függelékbe. ${ }^{294}$

Végül 1989-ben az afrikai elefántok átsorolásra kerültek az I. Függelékbe, azonban Japán továbbra is fenntartotta a jogot, hogy nyers elefántcsontot importáljon az afrikai CITES egyezményben részes államoktól. Az afrikai elefántok I. Függelékben való elhelyezésének voltak pozitív hozadékai is. A globális elefántcsont-kereskedelem mintegy 10-15 százalékát lebonyolító Amerikai Egyesült Államok teljesen megtiltotta az elefántcsont bevitelét. Az elefántcsordák újra gyarapodni kezdtek Dél-Afrikában, Zimbabwében, Botswanában, Zambiában, Malawiban és Namíbiában. A vadvilági menedzsment jól müködött az említett országokban, még ha néha ejtettek is el elefántokat, hogy a populáció ne haladja meg az élöhely eltartó képességét. Ugyanakkor a kereskedelmi változásoknak köszönhetően az érintett afrikai államok mintegy 470 tonna elefántcsontot raktároztak, mivel nem tudták azt eladni, még abban az esetben sem, ha az így befolyó jövedelmet az orvvadászat elleni küzdelemre szerették volna fordítani. Ennek eredményeként a ' 90 -es évektől kezdődően nagy erőfeszítéseket tettek, hogy az afrikai elefántok visszakerüljenek a II. Függelékbe, hogy a teljes tilalmat helyettesítse a korlátozott, de legális export. Fő érvük az volt, hogy a vadvilági megőrzés terhe nem a központi kormányzatra, hanem a kis közösségekre hárul, akik addig a legtöbbet profitáltak az illegális vadászatból. Éppen

\footnotetext{
${ }^{292}$ CITES III. cikk (5) bekezdés a) - c) pontok.

293 Consequences of the transfer of the african elephant from Appendix I to Appendix II. Doc. 7.43.1. https://cites.org/sites/default/files/eng/cop/07/doc/E07-43-01.pdf (2019. 01. 23.).

${ }^{294}$ Elephants and ivory trade in southern Africa. https://cites.org/eng/cop/07/doc/index.php (2019. 01. 23.).
} 
ezért a legális kereskedelemre úgy tekintettek, mint egyfajta ösztönző erőre, hogy a kis közösségek is felismerjék ezt a gazdasági alternatívát. 295

Az átsorolást ellenzők, köztük az USA és egyes afrikai államok is, mint Kenya megítélésében az afrikai elefántok II. Függelékbe való visszahelyezése utat nyitott volna az orvvadászatnak, mivel technikailag nem lehet különbséget tenni az orvvadászat eredményeképpen megszerzett és a legálisan ritkított csordákból származó elefántcsont között. További ellenérvek szerint az afrikai államok által felhozott gazdasági problémák orvosolhatók ökoturizmussal és nemzetközi segélyekkel. ${ }^{296}$

Az 1997-ben tartott részes felek konferenciáján három afrikai állam, Botswana, Zimbabwe és Namíbia javasolta, hogy az afrikai elefántok kerüljenek vissza a II. Függelékbe, tekintettel a populáció gyors növekedésre, miáltal csökkent a kihalás veszélye. Bár a javaslatot teljes terjedelmében nem fogadták el, az előbbi három afrikai állam tekintetében egy jegyezettel ellátott kiegészítés történt, amíg a többi állam tekintetében az afrikai elefántok megmaradtak az I. Függelékben. ${ }^{297}$ A három állam mintegy 59 tonna ${ }^{298}$ elefántcsontot kívánt Japánba szállítani és ott értékesíteni. Ennek megfelelően a három állam engedélyt kapott, hogy nem kereskedelmi célból trófeákat, élő állatokat megfelelő és elfogadható célállomásokra, valamint, hasítékbőrt, bőrtermékeket és elefántcsont-faragásokat $^{299}$ exportáljanak. Az Egyezmény módosítása 1999. szeptember 18-án lépett hatályba, onnantól számított 18 hónapig még nem volt engedélyezett az elefántcsonttal való kereskedelem. ${ }^{300}$

A II. Függelékbe sorolt fajok esetében a kereskedelmi kontroll célja, hogy elkerüljék a fennmaradásukkal összeegyeztethetetlen hasznosítást és a fajok példányai kereskedelmének hatékony ellenőrzése. A kivitelhez szükséges az exportengedély előzetes megadása és bemutatása. Az engedély akkor állítható ki, ha a kivitel helye szerinti állam Tudományos Testülete úgy foglal állást, hogy az export nem káros a kérdéses faj fennmaradása szempontjából. Az exportáló állam Igazgatási Hatósága megvizsgálja, hogy a példány megszerzése esetében betartották a vonatkozó állat- és növényvilág védelmére hozott

\footnotetext{
${ }^{295}$ HUNTER - SALZMAN - ZAELKE, 2007. 1109. p.

${ }^{296}$ Michael Lemonik: The Ivory Wars: After a Seven Year Ban, Three African Nations Want to Sell Tusks. Will the Rest of the World Allow it? Time, 1997. június 16. ://content.time.com/time/magazine/article/0,9171,986539,00.html (2019. 01. 23.).

${ }^{297}$ Res. Conf. 10.9. Consideration of proposals for the transfer of African elephant populations from Appendix I to Appendix II.

298 Országokra lebontva: Botswana: 25.3 tonna, Namíbia: 13.8 tonna, Zimbabwe: 20 tonna.

${ }^{299}$ Hasítékbőrt, bőrtermékeket és elefántcsont-faragásokat csak Zimbabwe.

${ }^{300}$ Amendments to Appendices I and II of the Convention 151. p.

https://cites.org/sites/default/files/eng/cop/10/E10-amendments.pdf (2019. 01. 23.).
} 
jogszabályokat és élő példányok szállítása esetében megfelelö körülményeket biztosítanak. ${ }^{301} \mathrm{Az}$ Egyezményben részes fél államok Tudományos Testületei folyamatosan figyelemmel kísérik a II. Függelékbe tartozó fajok esetében kiállított exportengedélyeket és a tényleges kivitelt. Amennyiben felmerül a „,kérdéses faj elterjedési területén az érintett ökológiai rendszerekben játszott szerepének megfelelö szintü fenntartása érdekében” a magasabb szintű védelem biztosításának és az I. Függelékbe való felvétel szükségessége, a Tudományos Testület javaslata alapján az Igazgatási Hatóság korlátozza a kiviteli engedélyek kiadását. ${ }^{302} \mathrm{~A}$ bevitelhez exportengedély vagy re-exportbizonyítvány előzetes bemutatása szükséges. Az újrakivitelhez szükséges a re-export bizonyítvány előzetes megadása és bemutatása. Az újrakiviteli bizonyítvány kiadásához a re-exportáló állam Igazgatási Hatósága meggyőződik az importálás jogszabályszerüségéről és az élő példányok szállításának körülményeiröl. ${ }^{303}$ A II. Függelék esetében is külön szabályozásra kerül a tengerről történő bevitel, amelynél egy évet meg nem haladó időszakra, a bevitelre kerülő példányok teljes száma is meghatározható a Tudományos Testület javaslatára. ${ }^{304}$ A 10.10-es határozat nagyon szigorú szabályokat és követelményeket állított fel az afrikai elefántokkal folytatott kereskedelem tekintetében. Többek között szigorú monitoring rendszert alakítottak ki, és az érintett államoknak bizonyítania kellett, hogy az eladott elefántcsont nem orvvadászatból származik. Ezentúl a kereskedelmi haszon jelentős részét egyenesen az afrikai elefántok megóvására kellett fordítani. ${ }^{305}$ 1999-ben a CITES Állandó Bizottsága megállapította, hogy a követelmények teljesültek és a három érintett országban megtartották az aukciókat, amely során 49.574 tonna elefántcsontot adtak el (mintegy 5446 agyar) körülbelül 5 millió USD értékben. ${ }^{306}$ Azonban ekkor kezdtek el megmutatkozni a II. Függelékbe való áthelyezés negatív hatásai is. A kereskedelmi könynyítés hatására az illegális vadászat mértéke azonnal növekedésnek indult, Zimbabwében mintegy 50 százalékkal ugrott meg. Willis Makombe, aki akkoriban a Harare Nemzeti Park és Vadvilág Részleg vezetője volt, elmondta, hogy a döntés elött havonta mintegy négy, utána havonta hat elefántot mészároltak le az orvvadászok. Mivel az afrikai államok nem rendelkeztek megfelelő erőforrásokkal, továbbá az elefántcsont eredetét nagyon nehéz visszakövetni, az orvvadászat sokaknak újra vonzó tevékenységgé vált. Ghánában a

\footnotetext{
${ }^{301}$ CITES IV. cikk (2) bekezdés a) - c) pontok.

${ }^{302}$ CITES IV. cikk (3) bekezdés.

${ }^{303}$ CITES IV. cikk (5) bekezdés a) - b) pontok.

${ }^{304}$ CITES IV. cikk (6)-(7) bekezdések.

${ }^{305}$ Res. Conf. 10.10. Trade in elephant specimens.

${ }^{306}$ HUNTER - SALZMAN - ZAELKE, 2007. 1110. p.
} 
konferenciát követő szeptemberben 5 elefántot mészároltak le, az elefántcsont-kereskedelem tilalmának bevezetése óta először. A CITES kikényszerítésének hiányát jelzi, hogy Zimbabwe a tilalom ellenére és annak hatálya alatt is exportált elefántcsontot Japánba, Dél-Afrikába, az USA-ba, Kínába, Thaiföldre és Hong Kong-ba. ${ }^{307}$

A következő CITES konferencián, 2000-ben, Dél-Afrika tekintetében is a II. Függelékbe kerültek át az afrikai elefántok. Ugyanakkor Dél-Afrika a kormányzati raktárakban lévő és a Kruger Nemzeti Parkból származó egész elefántagyarak tekintetében kereskedhet legálisan elefántcsonttal. A 2000-ben meghatározott szabályok alapján jelenleg az afrikai elefántok az I. Függelékbe vannak sorolva, kivéve a Botswana, Namíbia és Zimbabwe területén élő populációt és Dél-Afrikát. ${ }^{308}$

A CITES szabályok kikényszerítése és ellenőrzése érdekében hatékony ellenőrző rendszert akartak létrehozni az elefántcsont-kereskedelemre, így létrejött a MIKE, ${ }^{309}$ az illegálisan megölt elefántok monitorozására. A monitoring rendszer 1997-ben, Hararéban került kialakításra, és 2013-ban, a 16.9. határozattal vizsgálták felül. 2001 óta a program afrikai államokban való müködése az Európai Unió finanszírozásával történik. A MIKE 30 afrikai és 13 ázsiai országban müködik. Figyelemmel kíséri az elefántok illegális vadászatát, ezzel segítve a megfelelő döntéshozást és jogalkotást az elefántok tekintetében. A MIKE megállapítja az orvvadászat mértékét, a $\mathrm{PIKE}^{310}$ számok alapulvételével. Az elmúlt néhány év mutatói kifejezetten negatív tendenciákat tükröznek, föleg Közép- és Dél-Afrika területén. A MIKE index 0,5 felett van, ami azt mutatja meg, hogy a halottan megtalált elefántok mintegy felét illegálisan ejtették el. Egyes területeken, mint Garamba, a PIKE index már 0,7 körüli értéket mutat. ${ }^{311}$

A CITES 27 olyan országot azonosított, amelyek különösen érintettek az illegális elefántcsont-kereskedelemben. ${ }^{312}$ Ezeket három csoportba sorolta: elsődlegesen aggályos (kilenc ország vagy terület pl. Kenya, Kína, Thaiföld, Vietnám); másodlagosan aggályos

\footnotetext{
${ }^{307}$ HITCH, SCOTT: Losing elephant wars: CITES and the , ivory ban”. J. INT'L \& COMP. L. Vol. 27:167 184-186. p.

${ }^{308}$ Amendments to Appendices I and II of the Convention 4.p.

https://cites.org/sites/default/files/eng/cop/11/other/E-Amendments_App.pdf (2019. 01. 23.).

${ }^{309}$ MIKE:Monitoring the Illegal Killing of Elephants: Jogellenesen megölt elefántok monitorizálása.

${ }^{310}$ PIKE: Proportion of Illegally Killed Elephants: Illegálisan megölt elefántok aránya.

${ }^{311}$ MIKE Report Levels and trends of illegal killing of elephants in Africa to 31 December 2016 - preliminary findings.

https://cites.org/sites/default/files/eng/prog/MIKE/MIKE_report_released_WWD_3Mar2017.pdf (2019. 01.23.).

${ }^{312}$ A mennyiségi mutatók megállapítását segítik a más rendszerek is: Elefánt Kereskedelmi Információs Rendszer (ETIS: Elephant Trade Information System), Afrikai Elefánt Adatbázis (African Elephant Database).
} 
(kilenc ország pl. Egyiptom, Gabon); és nyomkövetés szempontjából fontos (kilenc ország pl. Angola, Kambodzsa). Ezek közül 19 államot kért fel a CITES egy Nemzeti Elefántcsont $\mathrm{Akció}_{\text {terv }}{ }^{313}$ elkészítésére.

Az orvvadászat továbbra is nagy problémát jelent az afrikai államokban, tovább csökkentve az afrikai elefántok számát. A hatékony küzdelemhez szükséges, hogy azonosítani lehessen az elkobzott elefántcsont földrajzi eredetét, ezért 2010-ben egy, a törvényszéki módszereket is alkalmazó azonosító rendszert hoztak létre az ún. ivoryID-t, amely az izotópos ujjlenyomat példáját alkalmazza az elefántcsontra. Az elefántcsont-azonosító egyrészt alkalmas az elefántcsont korának, másrészt földrajzi eredetének meghatározására. A módszer fejlesztéséhez mintegy 716 mintát vizsgáltak meg, amelyeket múzeumoktól, vadászoktól, civil szervezetektől szereztek be, s melyek segítségével egy referencia-adatbázist hoztak létre Afrikára vonatkozóan. ${ }^{314}$

Az Egyezmény szabályainak gyakorlati megvalósítása leginkább a kereskedelmi tevékenység engedélyezése és felügyelete érdekében kiadott engedélyek és bizonyítványok rendszerében mutatkozik meg. Az egyes Függelékek kapcsán, az importra, az exportra és a re-exportra vonatkozóan a részes felek hatóságainak engedélyeket és bizonyítványokat kell kiállítaniuk. Az Egyezményhez csatolt függelékek irányt mutatnak az engedélyek és bizonyítványok tartalmára. Az exportengedélyek a megadástól számított hat hónapon belül használhatók fel. ${ }^{315}$ Minden engedélynek és bizonyítványnak tartalmaznia kell az Egyezmény nevét, a kibocsátó Igazgatási Hatóság nevét és azonosító bélyegzőjét, valamint az Igazgatási Hatóság által adott ún. ellenőrzési számot. ${ }^{316}$ Minden másolatot és eredeti példányt világosan meg kell jelölni. Az eredeti helyett, a másolt dokumentumok csak az eredeti példányon megjelölt mértékben használhatók. ${ }^{317}$ Amennyiben a példányok több küldeményben kerülnek szállításra, minden küldeményhez külön engedély vagy bizonyítvány szükséges. ${ }^{318}$ Bármely példány importáló állama Igazgatási Hatóságának érvénytelenítnie kell és be kell vonnia az adott példányra vonatkozólag már bemutatott exportengedélyt vagy re-export bizonyítványt és minden vonatkozó importengedélyt. ${ }^{319} \mathrm{~A}$ dokumentumok hamisításának megakadályozása érdekében az Igazgatási Hatóságok

\footnotetext{
313 NIAPs: National Ivory Action Plans https://cites.org/eng/news/pr/2016_trends_in_African_elephant_poaching_released_\%E2\%80\%93_CITES_MIKE_programme_03032017 (2019. 01. 23.)

314 IvoryID https://ivoryid.org/en/pages/about/how_it_all_began (2019.01.23.)

315 CITES VI. cikk (2) bekezdés.

${ }^{316}$ CITES VI. cikk (3) bekezdés.

${ }^{317}$ CITES VI. cikk (4) bekezdés.

${ }^{318}$ CITES VI. cikk (5) bekezdés.

${ }^{319}$ CITES VI. cikk (6) bekezdés.
} 
minden példányt ,jellel" láthatnak el, amely lehet kitörölhetetlen lenyomat, ólompecsét vagy más hasonló eszköz. ${ }^{320}$

Az afrikai elefántok esetén keresztül szemléltethető a legjobban, hogy egyes országok kitartó ellenállása miként gyengítheti meg az Egyezmény által biztosított védelmet, valamint megmutatkozik a kereskedelmi könnyítések illegális vadászatra gyakorolt hatása is. Az Egyezmény alaprendelkezései azonban nem alkalmazhatók a tranzit, vagyis átmenő forgalomra és a részes felek területén való rakodásra mindaddig, amíg a példányok vámhatósági ellenőrzés alatt állnak. ${ }^{321}$

További mentességek kerülnek meghatározásra, amikor az Egyezmény szabályait nem kell alkalmazni. Ide tartozik, ha az exportáló vagy re-exportáló állam Igazgatási Hatósága meggyőződött arról, hogy a példányt azelőtt szerezték be, hogy a CITES rendelkezéseit alkalmazni kellett volna és erröl bizonyítványt állít ki. ${ }^{322}$

Az Egyezmény mentességeket határoz meg - mind a három Függelékre vonatkozóan ha a példányok személyi vagy háztartási ingóságok, azonban ezt a kitételt nem lehet mindig alkalmazni. ${ }^{323}$

Különleges kivételek vonatkoznak arra, ha az adott faj egyede nem a vadonból származik. Ha az I. Függelékbe sorolt állatfaj példányait fogságban nevelik, vagy növényfaj egyedeit mesterségesen szaporítják kereskedelmi célból, azokra a II. Függelékben szereplő példányokra vonatkozó szabályokat kell alkalmazni. ${ }^{324}$ A fogságban nevelés vagy mesterséges szaporítás tényéről az exportáló állam Igazgatási Hatósága győződik meg és állít ki bizonyítványt, amelyet mind a három Függelékbe sorolt fajok esetében elfogadhatják a részes felek, bármely engedély vagy bizonyítvány helyett. ${ }^{325}$

\footnotetext{
${ }^{320}$ CITES VI. cikk (7) bekezdés.

${ }^{321}$ CITES VII. cikk (1) bekezdés.

322 CITES VII. cikk (2) bekezdés.

${ }^{323}$ CITES VII. cikk (3) bekezdés. Ezt a mentességet nem lehet alkalmazni a következő esetekben: „a) az I. Függelékben szereplö fajok példányai esetében, ha ezeket a tulajdonos azon Államon kívül szerezte be, ahol szokásos lakhelye van, és ebbe az Államba viszi be öket; vagy

b) a II. Függelékben szereplö fajok példányai esetében, ha:

(i) ezeket a tulajdonos azon Államon kívül szerezte be, ahol szokásos lakhelye van, és olyan Államban, ahol a természeti környezetböl való kiemelésük történt,

(ii) abba az Államba viszik be öket, ahol a tulajdonos szokásos lakhelye van, és

(iii) az az Állam, ahol a természeti környezetböl való kiemelésük történt, exportengedélyek elözetes megadását követeli meg az ilyen példányok bármilyen exportja elött; kivéve, ha az Igazgatási Hatóság meggyözödött arról, hogy a példányok beszerzése azt megelözöen történt meg, hogy az Egyezmény rendelkezései azokra alkalmazandók lettek volna."

${ }^{324}$ CITES VII. cikk (4) bekezdés.

325 CITES VII. cikk (5) bekezdés.
} 
Az általános, kereskedelemre vonatkozó szabályok nem alkalmazhatók növénygyüjteményi példányok vagy más múzeumi példányok nem kereskedelmi célú kölcsönzésére. ${ }^{326}$ Bármely részes állam engedélyek vagy bizonyítványok nélkül engedélyezheti az olyan példányok mozgását, amelyek egy utazó állatkert, vándorcirkusz, utazó állatgyüjtemény, növénykiállítás vagy más vándorkiállítás részét képezik, meghatározott feltételek teljesítése esetében. ${ }^{327}$

Az Egyezménynek, a kereskedelem kontrolljára vonatkozó szabályait - különösen az engedélyek, bizonyítványok és dokumentáció tekintetében - a részes államok belső jogszabályai egészítik ki.

${ }^{326}$ CITES VII. cikk (6) bekezdés. „A III-V. Cikk rendelkezései nem alkalmazandók növénygyüjteményi példányoknak vagy más konzervált, szárított vagy beágyazott múzeumi példányoknak vagy valamely Igazgatási Hatóság által kiadott vagy elfogadott jellel ellátott élö növényanyagnak az Államuk Igazgatási Hatósága által bejegyzett tudósok vagy tudományos intézmények közötti nem kereskedelmi kölcsönzésére, ajándékozására vagy cseréjére."

${ }^{327}$ CITES VII. cikk (7) bekezdés. „Ha: a) az exportőr vagy importőr az ilyen példányok összes részletét regisztráltatja az Igazgatási Hatóságnál, b) a példányok e cikk akár 2., akár az 5. bekezdése által meghatározott kategóriákba tartoznak; és c) az Igazgatási Hatóság meggyözödött arról, hogy minden élö példányt úgy szállitanak és gondoznak, hogy a lehetö legkisebbre csökkentsék a sérülés, az egészségi károsodás vagy a kegyetlen bánásmód veszélyét." 


\section{IV.3.3. A CITES-hez füzött fenntartások hatása a fajok védelmére}

A kritikai észrevételek sorából nem lehet kihagyni a fenntartások említését sem. Jelen esetben az a kérdés merül fel, hogy a fenntartások jelenlegi formában akadályozzák-e a CITES céljainak megvalósulását? Mennyiben élhetnek vissza a részes államok az egyes fajok védelme alól való kibújással? Összességében befolyásolja-e az Egyezményhez füzött fenntartások sora az a CITES végrehajtásának hatékonyságát?

A fenntartások kérdése az egyik olyan kritikus pont a CITES-re vonatkozóan, amely az egyezményi rendszer gyakorlati megvalósulását és ezen keresztül a veszélyeztetett fajok megőrzését, a tágabb értelemben vett célok elérését is érinti. Amíg alapvetően a nemzetközi egyezményekhez füzött fenntartások hasznosnak bizonyulnak, hogy az állam ne kényszerüljön adott specifikus rendelkezés betartására, addig a CITES-hez füzött fenntartások rendszere felelős egyes fajok kereskedelmi kizsákmányolásáért, amely a veszélyezteti vadvilágot. ${ }^{328}$

A fenntartások kialakulására a sok állam részvételével kötött, multilaterális egyezmények számának növekedésével került sor, amely együtt járt a nemzetközi szervezetek keretében kötött nemzetközi szerződések elfogadása során alkalmazott többségi elv elterjedésével is. Azonban a fenntarások egyre elterjedtebb alkalmazása szembe került a szerződések integritásának elvével. Bruhács szerint az áthidalhatatlan véleménykülönbségek, amelyek szükségessé tették a fenntartások alkalmazását, a nemzetközi közösség „,heterogenitásából" adódnak, amely miatt a többség által elfogadható álláspont a kisebbség számára elfogadhatatlan volt, szükségszerüvé téve a fenntartások engedését. ${ }^{329}$ A nemzetközi szerződésekhez füzött fenntatások alapvetően lehetőséget biztosítanak az államoknak arra, hogy egyes rendelkezések alkalmazását kizárják. A Szerződések jogáról szóló 1969. Bécsi Egyezmény ${ }^{330}$ szerint fenntartás „olyan bárhogyan fogalmazott és nevezett egyoldalú nyilatkozat, amellyel valamely állam egy szerzödés aláírása, megerősitése, elfogadása, jóváhagyása, vagy ahhoz történö csatlakozása során kifejezésre juttatja, hogy a szerzödés bizonyos rendelkezéseinek jogi hatályát a reá való alkalmazásban kizárni vagy

328 Alagappan, MeEnA: United States' Enforcement of the Convention on International Trade in Endangered Species of Wild Fauna and Flora, 10 Nw. J. Int'l L. \& Bus. 541 (1990) 553. p.

${ }^{329}$ BRUHÁCs JÁnOs: Nemzetközi jog I. Általános Rész. Dialog Campus Kiadó, 2008. Budapest-Pécs. 102. p. 103. bekezdés.

${ }^{330}$ Vienna Convention on the Law of Treaties. A nemzetközi szerződések jogáról szóló bécsi egyezmény. 1969. (1980.) UNTS vol. 1155, p. 331. Kihirdette: 1987. évi 12. tvr. [Továbbiakban: Bécsi Egyezmény, 1969.]. 
módositani óhajtja.”331 Így , ,a fenntartás arra szolgál, hogy egy állam akkor is részesévé válhasson egy többoldalú nemzetközi szerzödésnek, ha annak nem minden pontjával, de a túlnyomó részével egyetért. Ebben az esetben fenntartással él a számára elfogadhatatlan rendelkezéssel szemben, annak tartalmát magára nézve teljes egészében kizárja vagy módositja, azonban a szerzödés többi része kötelezi."332

A nemzetközi egyezményekhez füzött fenntartásokkal a Nemzetközi Bíróság is foglalkozott, jelen esetben a népirtás megelőzéséről és megtorlásáról szóló egyezményhez füzött fenntartások tárgyában hozott tanácsadó véleménye bír jelentőséggel. ${ }^{333}$ A tanácsadó véleményben a Nemzetközi Bíróság szakít a nemzetközi szerződések abszolút integritásának elvével. ${ }^{334}$ Lényegében azt az alaptételt fogalmazzák meg, hogy inkább legyen részes fél az egyezményben minél több állam, megvédve és elősegítve a szerződéses célok elérését, mintsem pusztán a szerződések integritásának teljes megőrzése érdekében kizárják azon államok csatlakozását, amelyek valamely fenntartással élnének. ${ }^{335}$ Utóbbi álláspont mutatkozik meg a Washingtoni Egyezmény kapcsán is, hiszen az elsődleges cél a CITES univerzális tagságának elérése volt, mintsem, hogy egyes államok csatlakozását pusztán az esetleges fenntartások tétele miatt megakadályozzák. Azt is mondhatnánk, hogy ha az univerzalitás és az integritás elvei találkoznak egymással, ott a modern nemzetközi szerződéses rendszerben az univerzalitás iránti igény kerül előtérbe.

A gyakorlatban a fenntartásokhoz hasonló jogintézmények is kialakultak a szerződésjogban, amelyek bár következményeiket tekintve mutatnak azonosságokat a klasszikus értelemben vett fenntartásokkal, azok inkább tekinthetők megszorító klauzuláknak vagy megállapodásoknak. ${ }^{336}$ Olybá tünhet, hogy az elérendő cél kivételével a fenntartások és a megszorító klauzulák minden tekintetben különböznek egymástól, hiszen utóbbiak nem egyoldalú kijelentések az államok részéről, hanem a szerződésben részes felek közötti, vagy egyes részes államok közötti megállapodás. Ahol a megszorító klauzulák magukban a nemzetközi egyezményekben találhatóak, ott a kiegészítések csak meghatározott részes felek tekintetében lépnek hatályba, vagy különböző egyéb eljárások kerülnek bevezetésre, amelyek elvezetnek a multilaterális egyezmények „kétoldalúsitásához”. Ha pedig

\footnotetext{
331 Bécsi Egyezmény, 1969. 2. cikk A kifejezések használata, 1. d) pont.

${ }^{332}$ SZALAI ANIKÓ: Nemzetközi szerződések. ijoten (Internetes Jogtudományi Enciklopédia), 2018. [29] https://ijoten.hu/szocikk/nemzetkozi-szerzodesek (2019. 08. 01.)

${ }^{333}$ Reservations to the Convention on Genocide, Advisory Opinion: I.C.J. Reports 1951, 15. p. [Továbbiakban: Advisory Opinion, 1951.]

${ }^{334}$ KOVÁCs PÉTER: A nemzetközi jog fejlesztésének lehetőségei és korlátai a nemzetközi biróságok gyakorlatában. Pázmány Péter Katolikus Egyetem Állam- és Jogtudományi Kar, Budapest, 2010. 24. p.

${ }^{335}$ Advisory Opinion, 1951. 25. p.

${ }^{336}$ Angol nyelvü terminológiában: „Restrictive clauses and agrrements”.
} 
az ilyen jellegü eljárásokra és módszerekre fenntartásként tekintenek, az komoly félreértések forrása lehet. Több tárgykört felölelő nemzetközi egyezményben találhatóak a nemzetközi szerződésből eredő kötelezettségek korlátozására irányuló megszorító klauzulák. Az érintett nemzetközi szerződések között találhatóak környezeti, kereskedelmi, emberi jogi tárgykörüek is. ${ }^{337}$ A Nemzetközi Jogi Bizottság 2011-ben közreadott jelentése ${ }^{338}$ alapján a CITES VII. cikkében található „A kereskedelemre vonatkozó mentességek és más különleges intézkedések" között meghatározott kivételek is ebbe a kategóriába sorolhatók. Bár a megszorító klauzulák és a fenntartások célja hasonló, azok müködése egészen más: a megszorító klauzulák esetében az általános kizárás magából a szerződésből ered, míg a fenntartások esetében bár a lehetőség az egyezményböl ered, az csak a csatlakozással egyidejűleg tett egyoldalú állami nyilatkozat után éri el a kívánt hatást. ${ }^{339}$ Véleményem szerint a CITES kapcsán nem jelent különösebb problémát a fenntartások és a korlátozó intézkedések elkülönítése. Elsősorban, azok külön cikkekben kerülnek szabályozásra így a szerződés szövegéből eredő megszorító intézkedések jól érthető és különálló engedményeket, illetve egyéb lehetőségeket tartalmaznak. Továbbá, a Washingtoni Egyezmény ténylegesen csak az államok által tett nyilatkozatok kapcsán, a Függelékek módosítására használja a fenntartások kifejezést.

A fenntartások rendszere lehetőséget biztosít a részes feleknek, hogy egy számukra nem elfogadható módosításból kimaradjanak, ugyanakkor a fenntartások lehetősége éppen az Egyezmény lényegét kérdőjelezi meg, amely a veszélyeztetett fajoknak nyújtott védelem, azok kereskedelmének szabályozásán keresztül. A fö kérdés, hogyan tudná a CITES megvalósítani a célkitüzésit, ha a részes felek minden korlátozás nélkül távol maradhatnak a nekik nem tetsző, vagy nem előnyös rendelkezések megvalósításától? A Washingtoni Egyezmény nem engedi meg általános fenntartások tételét, azonban meghatározott cikkekhez kapcsolódóan lehetősége van a részes feleknek egyes rendelkezéseknek a kizárására. A Függelékek módosításával kapcsolatos eljárás során a CITES lehetőséget biztosít

\footnotetext{
${ }^{337}$ Környezeti tárgyú egyezmények közül ide sorolható pl. a Luganói Egyezmény környezetre veszélyes tevékenységekből eredő károk megtérítésére vonatkozó polgári jogi felelösségről (1993.) 4. cikke, vagy a környezetben tartósan megmaradó szerves szennyező anyagokról szóló Stockholmi Egyezmény (2001.) 4. cikke. A kereskedelmi tárgyú nemzetközi szerződések közül a GATT 1947 egyes rendelkezései, így XII., XIV., XX., XXI. cikkek. Az emberi jogi tárgyú egyezmények közül az 1966-ban elfogadott Gazdasági, Szociális és Kulturális Jogok Nemzetközi Egyezségokmányának 4. cikke kerül említésre a Bizottság jelentésében.

${ }^{338}$ Report of the International Law Commission. UN, New York, 2011. A/66/10/Add.1 124.p. [Továbbiakban: Report of the International Law Commission].

http://legal.un.org/docs/?symbol=A/66/10/Add.1 (2019. 08. 01.).

${ }^{339}$ Report of the International Law Commission, 125. p.
} 
fenntartások tételére. ${ }^{340}$ Valamint bármely állam a megerősítő, elfogadási, jóváhagyási vagy csatlakozási okiratának letétbe helyezésekor különös fenntartást terjeszthet elő az I., II. vagy III. Függelékben szereplő bármelyik faj, vagy a III. Függelékben szereplő fajra vonatkozóan közelebbről megjelölt bármely rész vagy származék tekintetében. Ameddig nem történik meg a fenntartás visszavonása, a részes felet úgy kell tekinteni, mint amely nem részese az Egyezménynek az ilyen fenntartásban pontosan megjelölt faj vagy részek, vagy származékok kereskedelme vonatkozásában. ${ }^{341}$ Az előbbiek alapján három módon lehet fenntartást füzni az Egyezményhez. Elöször is a Washingtoni Egyezményhez való csatlakozáskor, amely egészen a visszavonásig érvényes lesz. Továbbá, a Függelékek módosítása esetében, az I. és II., magasabb szintű védelmet biztosító Függelékek módosítási eljárása során, valamint a III. Függelékben szereplő fajok tekintetében.

Amennyiben egy faj törlésre kerül az egyik Függelékből és egyidejüleg egy másik Függeléken kerül listázásra, a részes feleknek az adott fajhoz szereplő fenntartásai érvénytelenné válnak. Így az érintett faj tekintetében a részes félnek új fenntartást kell tennie, ha továbbra is szeretné kizárni az Egyezmény alkalmazási köréből. ${ }^{342}$ Továbbá, a fenntartásoktól függetlenül a részes feleknek továbbra is dokumentációt és információt kell biztosítani - jelentéstételi kötelezettségük keretében - az adott fajok tekintetében is. ${ }^{343} \mathrm{~A}$ fenntartásokra vonatkozó szabályok értelmezése alapján, ha egy faj a II. Függelékből az I. Függelékbe kerül át, és ehhez a részes fél fenntartással él, továbbra is a biztosítania kell a II. Függelékhez füződő védelmet. Amennyiben pedig egy új faj kerül felvételre az I. Függelékbe és ehhez a részes fél fenntartást tesz, úgy kell tekinteni, mintha a faj a II. Függelékben szerepelne - beleértve a kereskedelem ellenőrzését és a dokumentációt. ${ }^{344}$ Így érdekes kérdésként merül fel, mi történik, ha egy olyan államba importálják az I. Függelékben szereplő faj egyedét, amely bár részes fél az Egyezményben, fenntartással élt. Ha az exportáló állam nem él fenntartással, az importengedély kibocsátása után szükséges lesz az exportengedély. Azonban az importáló állam részéről elegendő az export engedély vagy re-export bizonyítvány. ${ }^{345}$

\footnotetext{
${ }^{340}$ CITES XV. és XVI. cikkei alapján.

${ }^{341}$ CITES XXIII. Cikk. (1)-(3) bekezdések.

${ }^{342}$ Res. Conf. 4.25 (Rev. CoP14) Reservations 3. pont.

${ }^{343}$ Res. 4.25 (Rev. CoP14) 4. pont.

${ }^{344}$ CITES Secretariat Reservations 4. p. [Továbbiakban: Reservations ppt]. https://cites.unia.es/cites/file.php/1/trainers/Reservations.ppt (2019. 01. 21.).

${ }^{345}$ Reservations ppt 10. p.
} 
A legtöbb esetben a részes államok gazdasági célzatból élnek fenntartással olyan fajok tekintetében, amelyek kereskedelme jelentős bevételt jelent. Azonban ez alapjaiban ássa alá az Egyezmény céljait. Az előbbiek alapján meg kell indokolni, miért is engedték meg egyáltalán a fenntartások tételének lehetőségét? Az első érv, hogy a fenntartások lehetősége a Washingtoni Egyezmény általános támogatottságát segíti elö, hiszen az államok kivonhatják magukat egy-egy faj kereskedelmi korlátja alól. Másrészt a CITES célja a kereskedelem kontrollja, nem a teljes tilalom, így a fenntartások lehetősége elősegíti az Egyezmény általános támogatottságát, a kereskedelem magas szintű és kiterjedt szabályozása mellett. A fenntartások nélkül az Egyezmény arra kényszerítené az államokat, hogy válasszanak a teljes védelem és a védelem abszolút hiánya között. Végül, az Egyezmény szövegezői reménykedtek a fenntartások csak alkalomszerü, nem kiterjedt alkalmazásában. Azonban, ha két azonos tartalommal bíró fenntartást tevő állam között kerül sor kereskedelemre, az Egyezményben nem részes államokkal történő kereskedelmet szabályozó X. cikk védelme nem érvényesülhet. Az Egyezmény történetében több esetben is határozottan megállapítható volt a fenntartásokból következö hatékonyságcsökkenés, így a CITES céljai nem valósulhattak meg. A két széles körben említett példa a bordás krokodil (Crocodylus porosus) és a tengeri teknösök (superfamily Chelonioidea) esetei. 1979-ben Franciaország, Olaszország, az NSZK és Svájc megtagadta az egyezményi védelem kiterjesztését a bordás krokodilokra, mivel évente több mint egy millió krokodilbőrt állítottak elő, az akkori nemzetközi kereskedelem tárgyát képező termékek hatvan százalékát. Ezentúl Japán, amely a világ negyedik legnagyobb piaca volt a vizsgált időszakban, a krokodilbőrök tekintetében, szintén fenntartással élt az Egyezményhez való csatlakozásakor. Utóbbi eseményekre utalt Sand akképpen, hogy „első alkalommal ásta alá egy különösen veszélyeztetett faj globális védelmét az importáló államok ipari lobbistáinak összehangolt együttmüködése." 346

Az I. Függelékhez füzött fenntartásokkal az IUCN is foglalkozott. A Természetvédelmi Világszövetség határozatában megállapította, hogy a legmagasabb védelmi szintet jelentő Függelékhez tett fenntartások egyetlen célja, hogy a részes felek döntése által okozott esetleges gazdasági károkat rövid távon kiküszöbölje egy országra, vagy annak lakosaira nézve. Továbbá, kimondásra került az a tétel is, hogy a fenntartások hosszú távú

\footnotetext{
346 Stewart, GWyneth G.: Enforcement Problems in the Endangered Species Convention: Reservations Regarding the Reservation Clauses. Cornell International Law Journal. Vol. 14. (1981.) 435-439. p.
} 
megtartása aláássa az Egyezmény célkitűzéseit. ${ }^{347}$ Utóbbi megállapításból is leszürhető, hogy a CITES esetében a fenntartások leginkább átmeneti megoldásnak tekinthetők, amelyek lehetőséget adnak egy-egy országnak, hogy az újabb döntések esetleges gazdasági kockázatait mérsékeljék vagy kivédjék. Jelenleg is számos faj tekintetében éltek fenntartással a részes felek, azonban mivel a legveszélyeztetettebb fajokkal jellemzően csupán kevés számú állam folytat kereskedelmi tevékenységet, azok köre egyszerűen megállapítható. A következő táblázatban összegzésre kerültek azon részes felek, amelyek fenntartással éltek valamely I. vagy II. Függelékbe sorolt faj esetében, számszerüen megmutatva, összesen az egyes Függelékek tekintetében mennyi fenntartással éltek. ${ }^{348}$ A táblázat alapján is jól látható, hogy csak egyes államok folytatnak kereskedelmi tevékenységet a legveszélyeztetettebb fajokkal. Annak ellenére, hogy az Egyezmény szabályaitól való eltérést az IUCN is csupán átmeneti jellegünek tekinti, a legtöbb, jelenleg is hatályban lévő fenntartást a részes felek a csatlakozás során, a '80-as, '90-es évek végén tették. Jellemzően ezek a fenntartások gazdasági megfontolásokból erednek, az érintett fajok kereskedelmi szempontból bírnak jelentőséggel a részes felek számára. Például Japán, Izland és Norvégia a cetek rendjéhez élt fenntartásokkal, a delfinek, barna delfinek és bálnák tekintetében. Jól ismert tény, hogy az európai államok közül Norvégia és Izland folytat bálnavadászati tevékenységet, ${ }^{349}$ míg a Japán által folytatott egyes vadászati tevékenység már a Nemzetközi Bíróság előtt is tárgyalásra került. ${ }^{350}$ Így nem véletlen, hogy a CITES kapcsán is fenntartásokkal éltek a megnevezett államok. Szaúd-Arábia a sólyomfélékkel kapcsolatosan tér el az Egyezmény szabályaitól. Végül, de nem utolsó sorban, az I. Függelékhez tett fenntartások közül ki kell emelni a hüllökkel kapcsolatos kivételeket, amelyeket Palau, Kuba, Suriname és Szent-Vincent és a Grenadine-szigetek tettek.

\footnotetext{
${ }^{347}$ IUCN GA 1990 REC 040 Appendix I Reservations within CITES (A határozat elsősorban a Japán által tett nagyszámú fenntartásra vonatkozik.).

348 2. táblázat a szerző saját szerkesztése. A táblázat a 2019. augusztus 1-i állapotot tükrözi. Forrás: https://cites.org/sites/default/files/eng/app/2017/E-Reserv-2017-07-05.pdf (2019. 08. 01.).

${ }^{349}$ Norvégia és Izland az egyedüli olyan államok a világon, akik engedélyezik a bálnavadászati tevékenységet. Norvégia nem tarja magára nézve kötelezőnek a bálnavadászati moratóriumot, amely ellen 1986-ben tiltakozott is. Japán hivatalosan „tudományos kutatás” céljából vadászik, bár az elejtetett egyedek legnagyobb része gazdasági célú felhasználásra kerül, például, éttermek részére árulják.

See Agence France-Presse: Norway boots whaling quota despite international opposition. https://www.theguardian.com/environment/2018/mar/07/norway-boosts-whaling-quota-international-opposition (2019. 08. 02.).

${ }^{350}$ Whaling in the Antarctic (Australia v. Japan: New Zealand intervening), Judgment, I.C.J. Reports 2014, 226. p.
} 
2. táblázat Fenntartások az I. és II. Függelékekhez

\begin{tabular}{|c|c|c|}
\hline Fenntartást tevő állam & I. Függelék & II. Függelék \\
\hline Dánia & & 1 \\
\hline Dél-Korea & & 3 \\
\hline Egyesült Arab Emírségek & 1 & 1 \\
\hline Észak-Macedónia & 1 & 1 \\
\hline Fülöp-szigetek & 3 & \\
\hline Guyana & & 6 \\
\hline India & & 1 \\
\hline Indonézia & & 3 \\
\hline Izland & 8 & 14 \\
\hline Japán & 10 & 11 \\
\hline Jemen & & 3 \\
\hline Katar & & 2 \\
\hline Kongói Demokratikus Köztársaság & 1 & \\
\hline Kuba & 2 & \\
\hline Kuvait & & 2 \\
\hline Liechtenstein & & 6 \\
\hline Malawi & 1 & \\
\hline Namíbia & 1 & \\
\hline Norvégia & 5 & 4 \\
\hline Palau & 15 & 19 \\
\hline $\begin{array}{l}\text { Saint Vincent és a } \\
\text { Grenadine-szigetek }\end{array}$ & 2 & \\
\hline Suriname & 3 & \\
\hline Svájc & & 8 \\
\hline Szaúd-Arábia & 16 & 1 \\
\hline Szíriai Arab Köztársaság & & 2 \\
\hline
\end{tabular}


Tagság szempontjából 183 részes fél állammal a CITES gyakorlatilag univerzális egyezménynek tekinthető. Már a '70-es évektől kezdődően felmerültek a fenntartásokkal kapcsolatos problémák. Ezek közül kiemelendő, hogyha két, azonos fenntartást tevő állam folytat kereskedelmi tevékenységet egymással, akkor nem érvényesül az Egyezmény X. Cikke által támasztott védelmi szint sem. ${ }^{351}$ Valóban igaz az a megállapítás, hogy a fenntartások engedése elősegíti az Egyezményhez való csatlakozást, hiszen így olyan államok is részes féllé váltak, amelyek nem értettek egyet bizonyos kereskedelmi tárgyú intézkedésekkel. Ugyanakkor a CITES fő célja a veszélyeztetett, vadon élö állat- és növényfajok védelme, azok kereskedelmének szabályozásán keresztül. Ha gazdasági érdekből, az államok fenntartással élhetnek, akkor vajon mennyire kérdőjeleződik meg a fő célkitüzés? Több faj esetében megmutatkozott, hogy a fenntartások jelentősen alááshatják a fajmegőrzési kísérleteket és éppen ez a kritikai észrevétel az, amely talán a legnehezebben orvosolható. Ha egy-egy állam gazdasága jelentős mértékben egy adott fajra vagy abból készült termékekre épül, az ipari lobbinak nagy szerepe lehet az államok CITES kapcsán képviselt álláspontjának kialakítására. Utóbbi mutatkozott meg a bordás krokodilok kereskedelmi szabályozásában is, amikor 1979-ben azokat áthelyezték volna az I. Függelékbe. Abban az esetben, ha pont a kereskedelmi tevékenység nagyobb részét lebonyolító részes felek nem támogatják a szigorúbb szabályozást, a CITES célkitűzések megvalósulása ténylegesen csorbulhatnak a fenntartások tételével. Ugyanakkor a mai nemzetközi szerződésjogtól nem lehet idegen a fenntartások engedése és azok szerves részét képezik a multilaterális egyezményi rendszereknek. A szerződések integritása tehát már évtizedekkel ezelött fejet hajtott a sok, különböző érdeket képviselő állam egy adott egyezményben való tagságának elősegítésével szemben. Mivel a CITES I. Függelékében felsorolt különösen veszélyeztetett fajokkal csupán kis számú állam folytat kereskedelmi tevékenységet, alapvetően nem kérdőjelződnek meg teljesen a célok. Azonban ez csak általános megállapításnak tekinthető és a mai fajmegőrzési kísérletek során meg kell akadályozni, hogy a gazdasági érdekek akadályozzák a hatékony nemzetközi szabályozás elfogadását és így a veszélyeztetett fajok megőrzését.

\footnotetext{
${ }^{351}$ CITES X. cikk: „Ha olyan Államból vagy Államba történik export, re-export vagy import, amely nem részese az Egyezménynek, bármely Részes Fél az Egyezmény szerinti engedélyek és bizonyitványok helyett elfogadhatja a kérdéses Állam illetékes hatóságai által kibocsátott hasonló dokumentációt, ha az alapjában véve megfelel az egyezmény által az engedélyekkel és bizonyitványokkal kapcsolatban elöirt követelményeknek."
} 


\section{IV.3.4. A CITES végrehajtása és érvényesülése az államokban - megfe- lelés az Egyezmény által támasztott kötelezettségeknek}

A kritikai észrevételek egyik legfontosabb formája a kereskedelmi felfüggesztések köre és azok összeegyeztethetősége a nemzetközi kereskedelmi jogi szabályozással.

A nemzetközi szerződések esetében is fontos, hogy a részes államok eleget tegyenek az egyezményből eredő kötelezettségeknek, és azt megvalósítsák az adott államban. Ebben a tekintetben a multilaterális környezeti egyezmények sorában a CITES speciális helyet foglal el.

A legtöbb multilaterális környezeti egyezmény, megállapodás (MEA) tartalmaz szabályokat, specifikus rendelkezéseket az egyezmény betartását illetően, azonban a Washingtoni Egyezmény nem tartalmaz kifejezett cikkeket, amelyek az Egyezményből eredő kötelezettségek megszegésére vonatkoznak. Ugyanakkor nem mondhatjuk azt, hogy emiatt a CITES betartását semmilyen szabály nem érinti, hiszen annak ellenére, hogy az Egyezmény önmaga nem tartalmaz nevesített rendelkezéseket, a gyakorlatban széles körü „,következményrendszer" került kidolgozásra, ha egy részes állam nem tesz eleget a szerződésből eredő kötelezettségeinek. A következőkben elemzésre kerül, az egyes államok hogyan tehetnek eleget a Washingtoni Egyezménynek és milyen szankciórendszer került kialakításra az elmúlt évtizedekben. A CITES mint a vadvilági kereskedelmet érintő legfontosabb nemzetközi egyezmény, különösen nagy jelentőséggel bír az illegális vadvilági kereskedelem mértékére. Így a téma szempontjából feltétlenül szükséges annak feltérképezése, hogy a Washingtoni Egyezményben részes államokat milyen kötelezettségek terhelik az Egyezményhez való csatlakozással, és milyen szankciókkal kell szembenézniük szembe az előbbiek megsértése vagy elmulasztása esetében. A multilaterális környezeti egyezményeknek való nemzeti megfelelés kérdésével a UNEP is foglalkozott, különösen a kapacitásépítés és a hatékony, állami szintü végrehajtás tekintetében. ${ }^{352}$

Amennyiben egy állam részes fél a Washingtoni Egyezményben, legalapvetőbb kötelezettsége, hogy a Függelékek valamelyikében listára vett fajok kereskedelmét az Egyezmény rendelkezéseivel összhangban szabályozza és engedélyezze. ${ }^{353}$

\footnotetext{
${ }^{352}$ UNEP Governing Council decision SS.VII/4. (2002) Compliance with and enforcement of multilateral environmental agreements.

${ }^{353}$ CITES, III. cikk (1) bekezdés: I. Függelék, IV. cikk (1) bekezdés: II. Függelék, V. cikk (1) bekezdés: III. Függelék.
} 
- A szabályozás területe

A részes államoknak megfelelő kereskedelmi kontrollt kell biztosítaniuk, összhangban a vállalt nemzetközi kötelezettségekkel. Az Egyezmény kiterjed bármely, a függelékeiben szereplő faj élő, vagy élettelen egyedeire, bármely könnyen felismerhető részére vagy származékára, azok kereskedelmére, re-exportjára és tengerből való behozatalára. ${ }^{354}$

\section{- Dokumentációs követelmények}

Mivel a CITES fő célkitüzése a kereskedelem szabályozása és nem korlátozása, részletesen meghatározza a behozatal, kivitel vagy re-export során szükséges engedélyeket és bizonyítványokat. Így minden részes félnek kötelezettsége, hogy saját, belső jogi szabályozásában megvalósítsa a dokumentációkra vonatkozó követelményeket. ${ }^{355}$ Ugyanakkor igyekezniük kell olyan adminisztratív rendszer létrehozására, amely lehetőség szerint minimalizálja a kereskedelemmel kapcsolatos bürokratikus követelményeket.

\section{- Szállitással, vámkezeléssel kapcsolatos szabályok}

Továbbá ki kell jelölniük olyan be- és kilépőállomásokat, ahol a vámkezelést lebonyolítják. ${ }^{356}$ Külön gondoskodni kell az élő példányokkal való megfelelő bánásmód biztosításáról. ${ }^{357}$ A részes feleknek meg kell tiltaniuk minden kereskedelmi tevékenységet, amely ellentétes az Egyezmény szabályaival, valamint intézkedniük kell az ilyen jellegü kereskedelemben szereplő példányok elkobzásáról és az exportáló államba való visszaállításáról. Továbbá jogalkotással biztosítani kell a jogellenes kereskedelem vagy birtoklás vagy mindkettőnek hátrányos jogkövetkezményekkel való sújtását. ${ }^{358}$

\section{- Jelentéstétel}

A CITES elöírja részletes nyilvántartások vezetését az I-III. Függelékben szereplő fajok példányainak kereskedelmi forgalmáról, amelyek meghatározott, részletes információkat tartalmaznak. ${ }^{359}$

\footnotetext{
${ }^{354}$ CITES I. cikk: Meghatározások.

${ }^{355}$ CITES VI. cikk Engedélyek és bizonyítványok.

${ }^{356}$ CITES VIII. cikk (3) bekezdés $A$ részes felek által foganatositandó intézkedések.

${ }^{357}$ CITES VIII. cikk (3) bekezdés ,,...valamennyi élő példányt az átszállitás, tartás vagy szállitmányozás minden szakaszában a megfelelö módon gondozzanak úgy, hogy a lehetö legkisebbre csökkentsék a sérülés, az egészségkárosodás vagy a kegyetlen bánásmód, kezelés veszélyét."

${ }^{358}$ CITES XVIII. cikk (1) bekezdés (a) - (b) pontok.

${ }^{359}$ CITES VIII. cikk (6) bekezdés (a) - (b) pontok.

„... a kiadott engedélyek és bizonyítványok számát és típusát; azokat az Államokat, amelyekkel ilyen kereskedelmet bonyolitottak le; a példányok számát vagy mennyiségét és típusát, a fajok nevét az I-III. Függelék szerint, és ahol ez alkalmazható, a kérdéses példányok méretét és nemét."
} 
Az Egyezmény végrehajtása érdekében a feleknek megfelelö intézkedéseket kell foganatosítaniuk, amely magában foglalja az időszakos jelentéstételt is. A jelentéstétel két területre terjed ki: először is a részes feleknek nyilvántartást kell vezetniük az I-III. Függelékben szereplő fajok példányainak kereskedelmi forgalmáról, amely kapcsán jelentésben tájékoztatnak a kiadott engedélyek és bizonyítványok számáról és típusáról; azokról az Államokról, amelyekkel ilyen kereskedelmet bonyolítottak le; a példányok számát vagy mennyiségét és típusát, a fajok nevét az I-III. Függelék szerint, és ahol ez alkalmazható, a kérdéses példányok méretét és nemét. ${ }^{360}$ Utóbbiakról éves jelentést tesznek a Titkárságnak. Másodsorban a részes felek kétévente jelentést tesznek az Egyezmény rendelkezéseinek érvényesítésére hozott jogalkotási, szabályozási és igazgatási intézkedésekről. ${ }^{361}$

- Szervezetrendszerrel kapcsolatos követelmények

Szervezetrendszeri szinten minden részes államnak ki kell jelölnie az Egyezmény végrehajtásához szükséges alapvető szerveket. Ennek alapján meg kell határozni egy vagy több Igazgatási Hatóságot, amely illetékes engedélyek vagy bizonyítványok kiadására, és legalább egy Tudományos Testületet. Mivel mind a két testületnek fontos szerepe van az engedélyek, bizonyítványok és tilalmak kapcsán, a kijelölésekben vagy felhatalmazásokban beállt minden változásról az érintett részes félnek értesítenie kell a Titkárságot, hogy ezt valamennyi más részes államhoz továbbíthassa. ${ }^{362}$

- Nemzeti jogalkotás fejlesztése

A nemzeti szabályozások fejlesztését és a megfelelőséget mozdítja elő a Nemzeti Jogalkotási Projekt, ${ }^{363}$ amelyet a részes felek nyolcadik konferenciáján fogadtak el.

\footnotetext{
${ }^{360}$ CITES VIII. cikk (6) bekezdés (b) pont.

${ }^{361}$ CITES VIII. cikk (7) bekezdés (b) pont.

${ }^{362}$ CITES IX. cikk (1)-(4) bekezdések Igazgatási hatóságok és tudományos testületek.

${ }^{363}$ A nemzeti jogalkotás segítő CITES program elnevezése: National Legislation Project.
} 


\section{IV.3.4.a) Megfelelőségi kérdések}

A CITES-hez kapcsolódó megfelelőségi kérdések előtt ki kell térni az ahhoz kapcsolódó fogalmakra. Napjainkra a széles körü egyezményalkotásnak köszönhetően környezeti egyezmények százai kerültek elfogadásra, amelyek közül jelen értekezés keretében is megnevezésre került néhány, a biodiverzitással kapcsolatosan nagy jelentőséggel bíró szerződés. Azonban minden nemzetközi egyezmény, így környezeti témakörben elfogadott szerződések esetében is, nem elegendő, ha azokban egy állam részes féllé válik, hanem szükséges az egyezményből eredő kötelezettségek teljesítése is. A Washingtoni Egyezménnyel kapcsolatosan három kérdés merül fel: az Egyezmény szabályainak nemzeti szintű megvalósítása; azok „átültetése” a belső jogba ${ }^{364}$, az Egyezményből folyó kötelezettségek állami szintü kikényszerítése, végrehajtása ${ }^{365}$ valamint az Egyezménynek való megfelelöség. ${ }^{366}$ A Washingtoni Egyezményben részes államokkal kapcsolatosan mind a három területen merültek fel problémák.

Környezeti témakörben a kikényszerítés ,egy kötelezettség megsértésére adott formális, jogilag körülírt reakcióként” lett megfogalmazva. El kell egymástól határolni a nemzetközi és nemzeti/állami szintü kikényszerítés dimenzióit. Az állami szintü kikényszerítés általában egyének által elkövetett jogsértések esetén történik. Nemzetközi szinten történő kikényszerítésről akkor beszélhetünk, ha egy állam mulasztja el teljesíteni a nemzetközi jogból eredő kötelezettségeit. Így a nemzetközi környezeti egyezmények nemzeti szintű végrehajtása és az azokból eredő kötelezettségek teljesítésének kikényszerítése az egyezmény szabályainak való megfelelést biztosítják. Azonban a megfelelés nem összetévesztendő a hatékonyság kérdésével, hiszen az egyezményekből eredő kötelezettségek minimális, az elfogadhatóság szintjén mozgó megvalósítása nem biztosítja a rendelkezések hatékony érvényesülését a gyakorlatban. ${ }^{367}$ A Washingtoni Egyezmény állami szintü megvalósításának hiánya több esetben maga után vonta a megfelelőségi eljárások lefolytatását és különösen a fejlődő államnak minősülő részes felek tekintetében előfordulnak súlyos hiányosságok az Egyezmény rendelkezéseinek megvalósításában.

A CITES 1975 júliusában lépett hatályba, így viszonylag régi egyezménynek tekinthető. Az elmúlt több mint négy évtizedben az államok gyakran kerültek szembe az Egyezmény

\footnotetext{
${ }^{364}$ Az Egyezményhez kapcsolódó eredeti, angol nyelvű rendelkezésekben: „implementation”.

${ }^{365}$ Az Egyezményhez kapcsolódó eredeti, angol nyelvü rendelkezésekben: „enforcement”.

${ }^{366}$ Az Egyezményhez kapcsolódó eredeti, angol nyelvü rendelkezésekben: „,compliance”.

367 ReEVE, RosALIND: Enhancing the International Regime for Protecting Endangered Spe-cies: the Example of CITES. Max-Planck-Institut für ausländisches öffentliches Recht und Völkerrecht. ZaöRV 63 (2003) 349-350. p.
} 
betartásából és a rendelkezések végrehajtásából eredö nehézségekkel, amelyek négy fö csoportba sorolhatók. A legtöbb esetben az Egyezmény cikkeinek értelmezése okozott gondot, hiszen az olyan kifejezések, mint „elsödlegesen kereskedelmi célzatból”, nem minden esetben egyértelműek, ahogyan arra a történeti jellegü problémáknál már korábban utaltam. Az értelmezésből eredő nehézségek oda vezetnek, hogy a Washingtoni Egyezmény szabályai nem egységesen kerülnek végrehajtásra az államokban. Ez gyengíti az egyébként létrehozni kívánt védelem mértékét. A problémák második csoportja abból adódik, hogy a CITES által támasztott kötelezettségeket nem valósítják meg nemzeti szinten. Utóbbi abból is adódhat, hogy egyes államok nem rendelkeznek megfelelő erőforrásokkal azok teljesítéséhez, például nem tudják finanszírozni a végrehajtó hatóságok müködését. Harmadsorban, számos részes fél a nem megfelelés általános kategóriáját valósítja meg, beleértve a rendszeres beszámolók küldésének vagy az illegális kereskedelem büntetésének elmulasztását. Végül, az Egyezmény szabályai betartásának megsértése megvalósulhat az egyes Függelékekben listázott fajokkal kapcsolatosan is. ${ }^{368}$

Az autentikus értelmezést a részes felek konferenciáján hozott határozatok biztosítják. Ezeket az általában minden második-harmadik évben tartott CoP-n, kétharmados többséggel fogadják el. Eddig több mint száz határozat került elfogadásra, amelyek kötelező erejét többsoron megkérdőjelezték. A határozatok kötelező erejét illetően éppen az Európai Közösségek Bizottsága és Franciaország közötti „,bolíviai szőrme” ügyben ${ }^{369}$ merült fel kérdés az Európai Bíróság előtt. Az ügyben 1986-ban Franciaország engedélyezte hatezer Geoffroy-macska szőrméjének Bolíviából történő behozatalát, miközben egy évvel korábban a részes felek konferenciája határozatot fogadott el a Bolíviából történő behozatal tilalmát illetően az érintett államban fellelhető illegális kereskedelem, hamis export és re-export engedélyek miatt. Az Európai Bíróság döntése alapján Franciaország elmulasztotta a kötelezettségei teljesítését azzal, hogy engedélyezte a szőrmék behozatalát. Ezzel kvázi kijelentette, hogy a részes felek konferenciáján hozott határozatok kötelező erővel bírnak, és azokat be kell tartani. ${ }^{370} \mathrm{Az}$ ügy azért is jelentős, mivel a CITES történetében Bolíviával szemben alkalmaztak először kereskedelmi embargót, amelyet azóta több mint száz esetben hoztak olyan államokkal szemben, amelyek vagy megsértették az

\footnotetext{
${ }^{368}$ Beyerlin, UlRICH - STOLl, PETER-TOBIAS - WOLFRUM, RÜDLIGER: Conclusions drawn from the Conference on Ensuring Compliance with MEAs. Studies on the Law of Treaties: Ensuring Compliance with Multilateral Environmental Agreements. Brill | Nijhoff., Vol. 2. (2006.) 92. p.

${ }^{369}$ Az Európai Közösségek Bizottsága kontra Francia Köztársaság. ECLI:EU:C:1990:427 [Továbbiakban: ECLI:EU:C:1990:427].

${ }^{370}$ ECLI:EU:C:1990:427 7. (1) bekezdés és döntés.
} 
Egyezményböl eredő kötelezettségeik teljesítését, vagy az Egyezményben nem részes államok tekintetében, amelyek nem biztosítottak összehasonlítható és megfelelő dokumentációt. A CITES határozatokban megalkotott eljárási rend és kereskedelmi felfüggesztések rendszere kérdéses, mennyiben illeszkedik a létező nemzetközi közjogi és magánjogi keretekbe. A nemzetközi közjog területén leginkább az államok felelősségének kérdése és a felelősségi tervezettel ${ }^{371}$, míg a nemzetközi kereskedelmi jog tekintetében a WTO szabályrendszerével való összeegyeztethetőség merülnek fel. ${ }^{372}$

Amennyiben a CITES rendszerét be kellene sorolni valamely kategóriába, az leginkább a „kvázi jogalkotási hatáskörrel” rendelkező csoportba sorolható. Olyan esetekhez hasonlítható, ahol a nemzetközi szervezetek által hozott normákat nem kell ratifikálni, így általában biztosítják a döntésből való kimaradás, „opt-out” lehetőségét. Ez a szisztéma több MEAs esetében is megfigyelhető, így a CITES esetében is. Számos nemzetközi környezeti egyezmény menedzselését végző szervezet alkalmaz a függelékek vagy mellékletek módosításából való kimaradási lehetőséget biztosító eljárásokat. Ehhez hasonlatosan a CITES Függelékeinek módosításakor is minden esetben, mind a három Függelék változtatásakor lehetősége van a részes feleknek azoktól fenntartásokkal távol maradni. A Függelékek módosításával foglalkozó részletszabályokat 1994-ben alkották meg. Az ún. „Everglades-kritériumok” elvileg nem kötelező formában kerültek elfogadásra, azonban a módosítási eljárás nagyban ennek az értelmezése útján valósul meg. ${ }^{373} \mathrm{~A}$ Washingtoni Egyezmény nem határozza meg a részes felek által elfogadott javaslatok megjelenési formáját. Nagyvonalúan pusztán ,javaslat” formájában elfogadható döntésekről beszél, amely általában nem kötelező normákat jelent. 1994 óta határozatok, ${ }^{374}$ felülvizsgált határozatok $^{375}$ és döntések ${ }^{376}$ kerülnek elfogadásra a CoP-n. Míg a döntések általában csak egy-egy konferenciára és a következő konferenciáig érvényesek, a határozatok hosszú távú hatással bírnak. Mindazonáltal egyre több olyan döntéssel találkozhatunk, amelyeknek a határozatéhoz hasonló következményei vannak. Az Egyezmény szövegezésében található javaslatok határozati és döntési formában olyan rendszerré alakultak át, amelyek bár főszabály szerint nem rendelkeznek jogi kötőerővel, a CITES szövegezésekor előre

\footnotetext{
${ }^{371}$ International Law Commission: Draft Articles on Responsibility of States for Internationally Wrongful Acts, 2001.

372 SAND, PeTER H.: Endangered Species, International Protection. Max Planck Encyclopedia of Public International Law. Oxford University Press. Vol. 3. (2012.) Online elérhető: 2017. március 18. p.

${ }^{373}$ SOMMER, JULIA: Environmental Law-Making by International Organisations. Max-Planck-Institut für ausländisches öffentliches Recht und Völkerrecht. ZaöRV 63 (1996.) 646-647. p.

${ }^{374}$ Az Egyezményhez kapcsolódó eredeti, angol nyelvü terminológiában: „resoution”.

${ }^{375}$ Az Egyezményhez kapcsolódó eredeti, angol nyelvü terminológiában: „revised resolution”.

376 Az Egyezményhez kapcsolódó eredeti, angol nyelvű terminológiában: „decision”.
} 
nem látható követkeményekkel járnak. A határozatokat a jogilag kötelező dokumentumokra jellemző szövegezéssel fogalmazzák és az Egyezményben részes fél államok jogait és kötelezettségeit befolyásolják. A határozatoknak való nem megfelelés pedig szigorú eljárásokat vonhat maga után. Összességében elmondható, hogy a részes felek konferenciáin elfogadott határozatok de facto jogalkotásnak minősülnek. ${ }^{377}$

A részes felek által megvalósítandó végrehajtási intézkedéseket pontosította az 1992-ben elfogadott határozat, ${ }^{378}$ amelyet a 14. és 15 . konferenciákon vizsgáltak felül. A határozat kiemeli, hogy az Egyezmény nemzeti kikényszerítése érdekében a részes felek körülbelül fele nem tett megfelelő intézkedésket. A részes felek konferenciája felhívta a Titkárságot azon részes államok azonosítására, amelyek elmulasztották legalább egy Igazgatási vagy Tudományos Testület létrehozását, elmulasztották az Egyezmény megsértésével folytatott kereskedelem tilalmát vagy annak büntetését, illetve az illegális kereskedelem tárgyaként szolgáló vagy birtokolt példányok elkobzását. ${ }^{379}$ A határozat kiemeli az Állandó Bizottságot, hogy határozza meg, mely részes államok nem fogadtak el megfelelő intézkedéseket az Egyezmény hatékony végrehajtása érdekében és fontolja meg a kereskedelem esetleges felfüggesztését is magában foglaló megfelelőségi intézkedések meghozatalát, a 14.3-as határozattal összehangban. ${ }^{380}$

Mivel önálló testület, amely az Egyezmény megfelelőségi kérdéseivel foglalkozik, nem került létrehozásra, ehhez kapcsolódó hatáskörökkel a részes felek konferenciája, az Állandó Bizottság, a Növény- és Állat Bizottságok és a Titkárság bírnak. ${ }^{381}$ A megfelelőséggel kapcsolatos egyezményi alapot a XIII. cikk adja, „Nemzetközi Intézkedések” címmel. Ha a Titkárság a hozzá érkezett tájékoztatás alapján arról győződött meg, hogy az I. vagy II. Függelékben szereplő valamelyik fajra káros hatást gyakorol az ezen fajhoz tartozó példányokkal folytatott kereskedelem, vagy hogy az Egyezmény rendelkezéseit nem hatékonyan hajtják végre, ezt az információt közölnie kell az érintett részes fél vagy részes felek megbízott Igazgatási Hatóságával. Ha bármely részes fél ilyen jelzett közlést kap, a lehető leghamarabb értesíti a Titkárságot minden lényeges tényről, ha jogszabályai ezt megengedik, és adott esetben orvosló intézkedéseket javasol. Ha a részes fél úgy véli,

\footnotetext{
${ }^{377}$ FUCHS, CHRISTINE: Convention on International Trade in Endangered Species of Wild Fauna and Flora (CITES) - Conservation Efforts Undermine the Legality Principle. German L. J. Vol. 09. No. 11. 2008. 1574-1576. p.

${ }^{378}$ Res. Conf. 8.4. (Rec. CoP15) National laws for implementation of the Convention.

${ }^{379}$ Res. Conf. 8.4. 1. bekezdés (a) pont i)-iv) alpontok.

${ }^{380}$ Res. Conf. 8.4. 3. bekezdés.

${ }^{381}$ CITES Compliance and Enforcement Regime, expert meeting, 2012. Montreal. https://www.cbd.int/doc/meetings/abs/absem-comp-01/other/absem-comp-01-presentation-cites-en.pdf (2019. 01. 16.) [Továbbiakban: Meeting, 2012.].
} 
hogy kívánatos lenne vizsgálat lefolytatása, ezt a vizsgálatot a részes fél által kifejezetten feljogosított egy vagy több személy végezheti el. A részes fél által rendelkezésre bocsátott bármely érintett vizsgálatból származó információt meg kell vizsgálni a részes felek legközelebbi Konferenciáján, amely általa helyénvalónak tartott bármilyen ajánlást tehet. ${ }^{382}$

A megfelelőségi eljárások több lépcsőből állnak és a fokozatoság elve alapján müködnek. Az eljárások első lépcsője a lehetséges megfelelőségi kérdések azonosítása. Ha bármely részes felet aggodalommal tölt el bármely CITES-listázott faj példányaival folyatott kereskedelem egy másik részes állam részéről, közvetlenül megkeresheti az érintett részes felet vagy a Titkársághoz fordulhat segítségért. A Titkárság információt biztosít a megkereső részes fél számára a másik részes állam Egyezménnyel való megfelelésével kapcsolatosan. A részes feleket is arra biztatják, hogy biztosítsanak korai előrejelzést, ha nem tudják valamely, az Egyezményből folyó kötelezettségüket időben teljesíteni, például a meghatározott időpontig való információszolgáltatást. A második lépcsőfok a megfelelőségi kérdések megfontolása. Amennyiben egy részes fél elmulasztja a megfelelő javító intézkedéseket ésszerü határidőn belül megtenni, a kérdést a Titkárság továbbítja az Állandó Bizottsághoz. Az Állandó Bizottság tájékoztatása általában írásban történik, a megfelelő részletek feltárásával, az elmulasztott kötelezettségekre és a mulasztás lehetséges indokaira is kitérve. Az Állandó Bizottság elutasítja azon megfelelőségi kérdéseket, amelyek triviálisak vagy alaptalannak bizonyulnak. Amennyiben a megfelelőségi kérdést nem sikerül orvosolni, az Állandó Bizottság egy vagy több intézkedést is hozhat az alábbiak közül:

- tanács, információ vagy segítség biztosítása;

- különleges beszámoló kérése;

- írásbeli felszólítás küldése, válaszkéréssel és segítségajánlással;

- különleges intézkedések ajánlása;

- az érintett részes fél kérése alapján segítségnyújtás, amely lehet technikai is;

- nyilvános értesítés küldése minden részes félnek, a Titkárságon keresztül, felhívva a figyelmet a megfelelőségi problémára;

- figyelmeztetés kibocsátása;

- megfelelőségi akcióterv benyújtására való felhívás.

${ }^{382}$ CITES XIII. cikk Nemzetközi Intézkedések (1)-(3) bekezdések. 
Néhány esetben az Állandó Bizottság egy vagy több CITES listán szereplő faj kereskedelmének felfüggesztéséről dönt. A kereskedelem felfüggesztésére akkor van lehetőség, ha a részes fél nem felel meg az Egyezmény által támasztott kötelezettségeknek, amely mulasztás állandósul és megoldatlan marad, valamint a részes fél nem mutat hajlandóságot a megfelelőség elérésére vagy nem nyújtja be a X. Cikk ${ }^{383}$ által megkövetelt dokumentációt. A kereskedelem felfüggesztése minden esetben kimondottan és kizárólagosan az Egyezményen és a részes felek konferenciáin elfogadott határozatokon és döntéseken alapszik. Amennyiben az Állandó Bizottság megfontolja egy vagy több intézkedés meghozatalát, figyelembe veszi a részes fél lehetőségeit, a megfelelöségi kérdés típusát, mértékét és gyakoriságát, az arányosság elvét és a lehetséges pozitív hatásokat a vadvilág megörzésére és fenntartható használatára. Az Állandó Bizottság által hozott intézkedéseket minden esetben felügyelik a Titkárság segítségével. A részes fél által benyújtott különleges riport vagy egyéb információ alapján az Állandó Bizottság megvizsgálja az elörelépést és további intézkedések alkalmazásáról dönthet. A kereskedelem felfüggesztését elrendelő intézkedéseket azonnal vissza kell vonni, amennyiben a megfelelőségi kérdés megoldódott vagy jelentős előrelépés történt a részes fél részéröl. Az Állandó Bizottság jelent a részes felek konferenciájának megfelelőségi kérdésekben. A Titkárság jelentést tesz az Állandó Bizottságnak és a részes felek konferenciájának az érintett kérdésekben. ${ }^{384}$

${ }^{383}$ CITES X. cikk Kereskedelem az Egyezményben nem részes Államokkal. „Ha olyan Államból vagy Államba történik export, re-export vagy import, amely nem részese az Egyezménynek, bármely Részes Fél az Egyezmény szerinti engedélyek és bizonyitványok helyett elfogadhatja a kérdéses Állam illetékes hatóságai által kibocsátott hasonló dokumentációt, ha az alapjában véve megfelel az egyezmény által az engedélyekkel és bizonyítványokkal kapcsolatban elöirt követelményeknek." ${ }^{384}$ Meeting, 2012. 11-18. p. 


\section{IV.3.4.b) „A nem felelt meg minősítés” - kereskedelmi felfüggeszté- sek}

A kereskedelmi felfüggesztések a megfelelőségi eljárásokat követő legsúlyosabb következménynek tekinthetők. A CITES azonban a kereskedelem felfüggesztésére irányuló határozatokat „ajánlásnak” tekinti, amelyek a gyakorlatban azonban szinte kivétel nélkül érvényesülnek. Egy állammal szemben egy időben több különböző határozat meghozatala is lehetséges, amelyek irányulhatnak egy meghatározott faj kereskedelmének felfüggesztésére, vagy akár minden CITES listán szereplő fajjal kapcsolatos kereskedelemre. Ilyen esetekben az engedélyek és bizonyítványok kibocsátásakor minden körülményt figyelembe kell venni a részes felek igazgatási hatóságainak. A CITES interpretációjában a kereskedelmi felfüggesztésre vonatkozó ajánlások célja egyértelműen az, hogy előmozdítsa a részes feleknek az Egyezménynek való megfelelőségét. A határozatok meghozatalának három fő oka: a megfelelő jogalkotás elmaradása, az illegális vadvilági kereskedelem és a jelentéstételi kötelezettség elmulasztása. ${ }^{385}$ Jelenleg több mint két tucat, többségében afrikai és ázsiai állammal szemben élnek kereskedelmi felfüggesztések. A részes államokat értesítés ${ }^{386}$ formájában informálják, hogy mely államokkal szemben ajánlják a kereskedelem felfüggesztését, hivatkozva a határozat meghozatalának okára és a felfüggesztés terjedelmére.

Mindazonáltal a kereskedelmi felfüggesztések tekintetében nem kerül alkalmazásra a szankció kifejezés. A részes felek konferenciáin hozott határozatok helyzetét a fentiek alapján úgy összegezhetnénk, hogy a CoP a CITES alapján kizárólag javaslatok tételére jogosult, amely az elmúlt évtizedekben de facto jogalkotásnak minősülő, az államok szerződésből eredő jogait és kötelezettségeit érintő, egyedi határozati rendszerré formálódott. A kereskedelmi felfüggesztéseket annak érdekében alkalmazzák, hogy a részes államok teljesítsék szerződésből eredő kötelezettségeiket és megfeleljenek a CITES-nek. A határozatokról a részes feleket értesítik, amely elvileg azt jeleni, hogy ajánlják a határozatban megnevezett államokkal szemben, az abban foglalt mértékü korlátozás követését. Ugyanakkor bebizonyosodott, hogy az így hozott határozatok be nem tartása ugyancsak a CITES-ből eredő kötelezettségek be nem tartását jelenti. Amennyiben egy állam részes fél egy nemzetközi szerződésben, köteles mindent megtenni annak érdekében, hogy a

\footnotetext{
${ }^{385}$ Countries currently subject to a recommendation to suspend trade. https://www.cites.org/eng/resources/ref/suspend.php (2019. 01. 21.).

${ }^{386}$ Az Egyezményhez kapcsolódó eredeti, angol nyelvű terminológiában: „notification”.
} 
szerződésben foglaltak érvényesüljenek. Amennyiben a határozatokra úgy tekintünk, mint a CITES szabályainak érvényesülését garantáló instrumentumokra, azok betartásának kötelezettsége „idealizálható” a nemzetközi szerződések érvényesülésére vonatkozó általános nemzetközi jogi normákkal. Azonban a CITES kereskedelmi felfüggesztésinek rendszere gyakran olyan kérdéseket vet fel, amelyek megválaszolása, nemzetközi jogi alapokon nem vezet igazán kedvező eredményre - az Egyezmény tekintetében.

A Washingtoni Egyezmény lehetőséget biztosít a részes feleknek, hogy az CITES rendelkezéseinél szigorúbb szabályokat foganatosítsanak. ${ }^{387}$ Így a határozatokban megfogalmazott kereskedelmi felfüggesztésre vonatkozó ajánlás vezethet időleges, többoldalú kereskedelmi tilalomhoz, amely a célzott országok megfelelőségét nagyban előmozdítja. De mi teszi hatékony „büntetési” rendszerré ${ }^{388}$ a határozatokban megfogalmazott kereskedelmi felfüggesztéseket, amely a CITES-nek való megfelelőség irányába mozdítja a renitens részes feleket? Ahogyan korábban már említésre került, a vadvilági kereskedelem olyan hatalmas piaci lehetőség, amely számos állam esetében éves szinten több milliárd USD hasznot hoz, akár a nyersanyagok, akár az élő példányok vagy vadvilági termékek tekintetében. Ezért egy olyan kereskedelmi tilalom, amely minden CITES részes fél esetében kizárja a lehetőséget a listán szereplő egyedek tekintetében, nagy ösztönzést jelenthet az államok számára. A szakirodalom a CITES rendszerét a „,multilaterálisan felhatalmazott kereskedelmi embargó” prototípusának tartja. Ugyanakkor a kereskedelmi tevékenységben kulcsszerepet játszó államok részéről való végrehajtás nélkülözhetetlen a nemzetközi nyomásgyakorláshoz, amely végül megfelelésre sarkallja a részes feleket. ${ }^{389}$ A kritikai észrevételek egy másik területe azzal kapcsolatos, hogy a CITES alapján alkalmazható kereskedelmi felfüggesztések köre beilleszthető-e a nemzetközi jog rendszerébe. A CITES végrehajtásából eredő problémák, a megfelelőségi kérdések már részletesen tárgyalásra kerültek. Azonban a kritikai megközelítés egyik lényeges eleme az

\footnotetext{
387 CITES, XIV. cikk.
}

1. Az Egyezmény rendelkezései semmiképpen nem érintik a Részes Felek azon jogát, hogy

a) szigorúbb belsö intézkedéseket fogadjanak el az I-III. Függelékben szereplö fajok példányai kereskedelmének, befogásának, birtoklásának avagy szállitásának a feltételeivel vagy ezek teljes megtiltásával kapcsolatban; vagy

b) olyan belső intézkedéseket hozzanak, amelyek korlátozzák vagy megtiltják az I., II. vagy III. Függelékben nem szereplö fajok kereskedelmét, befogását, birtoklását vagy szállitását.

${ }^{388}$ A szakirodalomban a szankciók kapcsán tárgyalt „stick-carrot approach”, vagyis büntetési-jutalmazási rendszerben a CITES kereskedelmi felfüggesztésekre vonatkozó határozatait a „stick” vagyis büntetési típusú eszközök közé sorolják.

${ }^{389}$ SAND, Peter H.: Sanctions In Case of Non-Compliance And State Responsibility: Pacta Sunt Servanda - Or Else. Making Law Work: Environmental Compliance and Sustaina-ble Development. Cameron May Ltd., London, Vol. 1. (2005.) 263-265 p. 
Egyezmény gyakorlati megvalósításából eredő problémák említése. Az Egyezmény szabályainak kikényszerítése állandó kérdés a részes felek között, így több konferencián is foglalkoztak vele. A kereskedelmi embargó bevezetése lehetséges egy meghatározott szektor tekintetében és lehetséges általánosan, valamint az Egyezményben nem részes államokkal szemben is. Egyes államok korábbi kibújási lehetősége, vagyis az Egyezményben nem részes államokkal külső piacokon folytatott kereskedelem, ${ }^{390}$ gyakorlatilag megszünt az államok nagy részének csatlakozása következtében. A szankciós rendszer sikerességét azonban alátámasztja az, hogy a nem megfelelő végrehajtás következtében alkalmazott embargós intézkedések mintegy 80\%-ban egy éven belül feloldhatók voltak. Figyelemre méltó arány azonban, hogy a korlátozó intézkedéseket mintegy 95\%-ban a harmadik világ államaival szemben alkalmazták. A CITES alapján hozott szankciókat a „normatív diplomácia intézményesüléseként” szokták emlegetni. A jelenlegi szakirodalmi álláspontok szerint a CITES által alkalmazott kereskedelmi korlátozások összeegyeztethetők mind a nemzetközi jogi szabályokkal, mind pedig a Kereskedelmi Világszervezet rendszerével. Ez utóbbi igazolással szolgálhat, hogy e tekintetben még egyetlen állam sem fordult a WTO vitarendezési mechanizmusához. ${ }^{391}$ Utóbbi témakör kifejtése később történik meg részletesen.

\footnotetext{
${ }^{390}$ Ezt a jelenséget hívják úgy, hogy ,free-riding”.

${ }^{391}$ SAND, PETER H.: Enforcing CITES: The Rise and Fall of Trade Sanctions. Review of Eu-ropean Community \& International Environmental Law Vol. 22 (3) (2013). 251-263. p.
} 


\section{IV.3.4.c) A nemzetközi kereskedelmi jog kapcsolódási pontjai a Wa- shingtoni Egyezményhez}

Az elmúlt évtizedekben a szabadkereskedelem és a gazdasági globalizáció költségvonzatai, előnyei és hosszú távú hatásai a politikai közgondolkodás frontvonalába kerültek. Egyik fő vonatkozásnak tekinthető, hogy a kereskedelmi liberalizáció hogyan befolyásolja a környezetminőséget és közvetlenül vagy közvetve milyen hatással van a környezetre. Mára rendelkezésre állnak olyan becslési és adatelemzési módszerek, amelyekkel a környezeti hatások mértéke elég nagy bizonyossággal megbecsülhetők. ${ }^{392}$ Amikor a környezetminőség lehetséges változását vizsgálják, elsősorban a legfontosabb tényezőkre vonatkozó indikátorok alkalmazása történik. Így vizsgálat tárgyát képezi, hogy a gazdasági globalizáció milyen hatással lehet a szennyezőanyagok kibocsátására, a veszélyes hulladékok, anyagok termelésére és mennyiségére. A fő következtetés úgy vonható le, hogy nem is az a fő kérdés, hogy önmagában a szabadkereskedelem negatívan vagy pozitívan befolyásolja-e a környezetminőséget, hiszen a kutatások és a gyakorlat változó eredményeket mutatnak a különböző gazdasági szektorokban. Leglényegesebben a környezeti szabályozás hatékonysága, különösen az átmeneti időszakokban, amikor az államok megnyitják piacaikat a nemzetközi versenynek, az adminisztratív terhek csökkentése érdekében modernizálják a standardokat és szabályokat, megtörténik a piacok átalakítása. Az előbbiek fényében megállapítható, hogy a szabadkereskedelem felé nyitó államoknak a verseny-, beruházási- és kereskedelmi szabályok mellett ugyanakkora hangsúlyt kell fektetniük a környezetre vonatkozó jogi instrumentumok fejlesztésére is, kiküszöbölve az esetleges negatív hatásokat és már megelőzve azok jelentkezését. ${ }^{393}$ Egyes források ugyanakkor rámutatnak, hogy a szabadkereskedelem és a környezetminőség közötti öszszefüggés bonyolultabb, mint ahogy első pillanatban gondolnánk és több területre is kiterjednek: a bevételek növekedése és a környezetminőség iránti igény; környezeti termékekkel való közvetlen kereskedelem (hagyományos termékek pl. energiahordozók és környezeti szempontból hasznos termékek pl. organikus termékek); a környezeti

\footnotetext{
${ }^{392}$ Free Trade and the Environment: The Picture Becomes Clearer. Commission for Environmental Cooperation of North America 2002. Preface V.

The Environmental Effects of Free Trade: Papers Presented at the North American Symposium on Assessing the Linkages between Trade and Environment (October 2000), CEC 2002. [Továbbiakban: Free Trade and Environment 2002.].

${ }^{393}$ Free Trade and Environment 2002. 1-3. p.
} 
szabályozásra és a technikai fejlődésre való közvetett hatások. ${ }^{394}$ Jelen értekezés szempontjából a CITES és a WTO közötti összefüggések bírnak jelentőséggel, így eltekintve a szabadkereskedelem és a kereskedelmi globalizáció általános környezeti hatásainak részletes ismertetésétől, a fókuszpont az előbbi kérdésen van.

A kereskedelem és a természetvédelem, a fenntartható fejlődés közötti összefüggések vitathatatlanok, ahogy arra a Riói Nyilatkozat 12. elve is rámutat.

„Államok müködjenek együtt egy támogató és nyitott nemzetközi gazdasági rendszer elösegitésében, ami valamennyi országban gazdasági növekedéshez és fenntartható fejlödéshez vezethet annak érdekében, hogy jobban lehessen megoldani a környezetromlás problémáit. A környezeti célú kereskedelmi-politikai intézkedések nem képezhetnek önkényes vagy indokolatlan megkülönböztetést vagy rejtett korlátozást a nemzetközi kereskedelemben. Kerülni kell azokat az egyoldalú intézkedéseket; amelyek az importáló ország fennhatóságán túlmenően foglalkoznak a környezeti problémákkal. A határokon átterjedö vagy a globális környezeti problémákkal foglalkozó környezeti intézkedéseknek - amennyire lehetséges nemzetközi egyetértésen kell alapulniuk."395

A fenntartható fejlődés célkitüzése a WTO-t létrehozó Marrakeshi Egyezmény ${ }^{396}$ preambulumában is szerepel.

„...lehetővé teszik a világ erőforrásainak optimális használatát összhangban a fenntartható fejlödés céljával, kivánva mind a környezet védelmét és megóvását, mind az ezt szolgáló eszközök erösitését oly módon, ami megfelel igényeiknek és aggályaiknak a gazdasági fejlödés különbözö szintjein." 397

A WTO környezeti hatásaira vonatkozó vita hosszú múltra tekint vissza, azonban az utóbbi évtized irodalma kevésbé éles szemmel vizsgálja a Kereskedelmi Világszervezet ilyen irányú hatásait. ${ }^{398}$ Többek között kiemelésre kerül, hogy a WTO szabályrendszere önmagában nem akadályozza a létező multilaterális környezetvédelmi egyezmények érvényesülését és nem felelős az állami szintü környezetpolitika hiányosságaiért, valamint a vitarendezés sem elfogult a kereskedelmi érdekek iránt a környezeti megfontolásokkal

\footnotetext{
${ }^{394}$ GARDNER, B. DELWORTH: Globalization, Free Trade and Environmental Quality. Hoover Press: Anderson/Prosperity. DP0 HANDEP0400 rev1. 116. p.

${ }^{395}$ Rio Declaration on Enviornment and Development, 1992. 12. elv.

${ }^{396}$ Marrakesh Agreement Establishing the World Trade Organization. A Kereskedelmi Világszervezetet létrehozó Marrakeshi Egyezmény. Kihirdette: 1998. évi IX. törvény.

${ }^{397}$ A Kereskedelmi Világszervezetet létrehozó Marrakeshi Egyezmény, Preambulum.

${ }^{398}$ IRWIN, Douglas A.: Free trade under fire. Princeton, N.J.: Princeton University Press. 4. kiadás, 2015. IRWIN, DOUGLAS A.: Free trade under fire. The Milken Institute Review. Second Quater, 2002. 69-82. p.
} 
szemben. Ugyanakkor a jövőt tekintve a megállapítások kissé pesszimistának tekinthetők, hiszen a WTO keveset tett a környezetvédelem tényleges fejlesztéséért, az elővigyázatosság elve nem kerül figyelembevételre a kereskedelmi szabályok kidolgozása során és föként, nehéz lesz a szervezetet kimozdítani a jelenlegi, környezetminőséggel kapcsolatos nyugvópontról. ${ }^{399}$ Az összefüggés a CITES és a nemzetközi kereskedelmi szabályozás között egyértelmű. A Washingtoni Egyezmény elsősorban a veszélyeztetett fajok jogszerü kereskedelmének kereteit határozza meg és a fajok védelme csupán ezen keresztül valósul meg. Így mindenképpen megállapítható, hogy bizonyos fokú összeütközés lesz a nemzetközi kereskedelmi folyamatokat szabályozó egyezmények és a CITES között. Utóbbi különösen a kereskedelmi felfüggesztések kérdéskörében mutatkozik meg. Érdekes azonban, hogy a CITES részes felek konferenciái és az Állandó Bizottság által javasolt kereskedelmi korlátozások, felfüggesztések még sohasem kerültek megmérettetésre a WTO vitarendezési mechanizmusában. A téma kutatása során folyamatosan szembesülünk a kérdéssel, vajon a CITES a környezetvédelem instrumentuma vagy az államok eszköze, hogy a vadvilági kereskedelmet fenntartható keretek között tartsák? Az elöbbi kérdésre megnyugtató választ aligha kaphatunk. Azonban annyi biztos, hogy a CITES részes feleinek konferenciája már 1992-ben is határozatot ${ }^{400}$ fogadott el a „vadvilági kereskedelem elönyeinek elismeréséröl”, amelyet 2004-ben a 13. CoP-n vizsgáltak felül. A határozat kimondja, hogy a fajok és az ökoszisztéma védelmére, valamint a helyi közösségek fejlődésére a kereskedelemre hasznos is lehet, amennyiben a kérdéses fajok túlélésére nem hátrányos mértékben kerül kivitelezésre. ${ }^{401}$

A nemzetközi kereskedelmi jog története az I. világháború utáni időszakra vezet vissza, amikor az 1929-es gazdasági világválság idején az államok protekcionista intézkedéseket vezettek be. Ezek az intézkedések azonban a XX. század folyamán jelentősen megnehezítették a nemzetközi kereskedelmi tranzakciókat. A különböző import- és exportkvóták, vámterhek, mennyiségi korlátozások gátat szabtak az államok közti folyamatoknak. A Bretton Woods-i tárgyalások ${ }^{402}$ és a nemzetközi pénzügyi intézmények létrehozása mellett megfogalmazódott a Nemzetközi Kereskedelmi Szervezet megalapításának ötlete.

\footnotetext{
${ }^{399}$ NEUMAYER, ERIC: The WTO and the environment: its past record is better than critics believe, but the future outlook is bleak. Global environmental politics. 2004. Vol. 4. (3.) 1-8 p.

${ }^{400}$ Res. Conf. 8.3. (Rev. CoP 13.) Recognition of the benefits of trade in wildlife.

${ }^{401}$ Res. Conf. 8.3. (Rev. CoP 13.) 1. pont.

402 1944. július 1-től július 22-ig. Lásd. Tarján M. Tamás: 1944. július 22. Létrehozzák a Bretton Woods-i rendszert.

http://www.rubicon.hu/magyar/oldalak/1944_julius_22_letrehozzak_a_bretton_woodsi_rendszert/ (2019. 04. 21.)
} 
Bár az ITO létrehozására ${ }^{403}$ sohasem került sor, 1947-ben 27 állam megkötötte az Általános vám- és kereskedelmi egyezményt, amely egészen az 1990-es évek elejéig alapot biztosított a nemzetközi kereskedelmi szabályozásnak. A GATT a nem pénzügyi jellegü kereskedelmi akadályok felszámolásában nem volt olyan sikeres, mint a különböző vám, és vám jellegü terhek csökkentésében. Az 1986 és 1994 között tartott Uruguay tárgyalási forduló eredményeként létrehozták a Kereskedelmi Világszervezetet, amelynek 2016 júliusa óta 164 tagállama van. A nemzetközi kereskedelmi jog jelenleg a GATT 1994-re, a tizenkét kiegészítő egyezményre, az azok alapján folytatott gyakorlatra és a Marrakeshi jegyzőkönyvre épül. ${ }^{404}$ A WTO-tól nem idegenek a környezeti kérdések, hiszen többsoron is szembe került olyan esetekkel, ahol a kereskedelmi és környezeti megfontolások kerültek ütközőzónába.

A nemzetközi kereskedelmi jog egyes egyezményei is tartalmaznak „,zöld”, környezettel kapcsolatos rendelkezéseket, amelyeket az egyes államok figyelembe vehetnek. Utóbbiak általában a „emberi, állati vagy növényi élet vagy egészség védelméhez” kötődnek, amelyeket a részes államok figyelembe vehetnek állat- vagy növény-egészségügyi intézkedések, ${ }^{405}$ azonban ezeknek összhangban kell lenni a nemzetközi szabványokkal, irányelvekkel vagy ajánlásokkal, ${ }^{406}$ és el kell kerülni az önkényes vagy indokolatlan megkülönböztetéseket. ${ }^{407}$ Továbbá, lehetőséget biztosít olyan vállalatok támogatására, amelyek új környezeti intézkedéseket vezetnek be, a kiadások 20 százalékáig. 408

\section{A fö kérdés az, hogyha állam azt feltételezi, hogy egy másik állam kereskedelme kárositja} a környezetet, mit tehet - felfüggesztheti-e az érintett állammal folytatott kereskedelmet? Mivel kifejezetten ilyen kérdés még nem került a vitarendezési testület elé, a WTO általános rendelkezéseiből az vezethető le, hogy a feleknek együtt kell müködniük a környezet védelme érdekében. A környezeti indokok alapján bevezetett behozatali korlátozások nem lehetnek diszkriminatívak, és minden állammal szemben azonos standardokat kell alkalmazni. Amennyiben az érintett kérdésre valamilyen környezeti megállapodás vonatkozik, akkor annak a szabályai lesznek irányadók. Ha nem, a WTO rendelkezések alapján

\footnotetext{
${ }^{403}$ A Nemzetközi Kereskedelmi Szervezetet a Havannai karta hozta volna létre, amelyet 1948-ban írtak alá. Azonban a ratifikációs folyamat megakadása miatt az sohasem lépett hatályba.

${ }^{404}$ Kende TAMÁs - NAgY BoldizSÁR - Sonnevend PÁl - VAlKi LÁszló: Nemzetközi jog. Wolters Kluwer Kft. Budapest, 2014. 611-615. p.

405 GATT, Megállapodás az állat- és növény-egészségügyi intézkedések alkalmazásáról.

${ }^{406}$ GATT, Megállapodás az állat- és növény-egészségügyi intézkedések alkalmazásáról, 3. cikk.

${ }^{407}$ Kockázatbecslés és az állat- és növény-egészségügyi védelem megfelelő szintjének meghatározása 5. cikk 5. pont.

${ }^{408}$ Agreement on Subsidies and Countervailing Measures Part IV. Art. 8. bekezdés c. pont (ii.) alpontok.
} 
kell eljárni. Ezzel kapcsolatban két fontos szabályt kell megemlíteni: a kereskedelmi korlátozások nem alapulhatnak pusztán azon a tényen, hogy egy terméket milyen módon állítanak elő, valamint egy állam nem kényszerítheti rá az elöírásait egy másik államra. Ha két állam között vita merül fel egy ilyen intézkedéssel szemben, a vitarendezési testülethez fordulhatnak. ${ }^{409} \mathrm{~A}$ veszélyeztetett fajok védelme érdekében hozott hatékony rendelkezések alapvetően nem összeegyeztethetetlenek a nemzetközi kereskedelmi szabályokkal, ahogyan arra a tengeri teknös ügyben a vitarendezési testület is rámutatott. Azonban ezeknek a korlátozásoknak az alapvető elveknek és követelményeknek is meg kell felelnie. ${ }^{410}$

1994-ben Miniszteri Bizottsági döntés született egy külön, környezeti kérdésekkel foglalkozó bizottság létrehozásáról, amely napjainkban is müködik. A Kereskedelem és Környezet Bizottság szavatolja, hogy a WTO globális szinten, megfelelő mértékben hozzá tudjon járulni a környezeti kérdések tárgyalásához. A CITES 1997 óta állandó megfigyelöként müködik közre a CTE munkájában. ${ }^{411}$ A CTE a környezettel kapcsolatos kereskedelmi kérdések széles körét fogja át, és két alapelvre épül: a WTO nem környezeti ügynökség, nem célja, hogy beavatkozzon a nemzeti vagy nemzetközi környezetpolitikába; valamint a Bizottság feladata a problémák azonosítása és a megoldásoknak követniük kell a WTO kereskedelmi elveit. A CTE tevékenységi köre több területre kiterjed, ezek közé tartoznak: a környezeti kérdésekkel kapcsolatos viták rendezése, a WTO és a multilaterális környezeti egyezmények kapcsolata, az „eco-labelling”, az átláthatóság és információcsere, az olyan nemzeti szinten tiltott termékek, mint a veszélyes anyagok vagy kemikáliák, a kereskedelem liberalizációja és a fenntartható fejlődés, valamint a szellemi alkotások és szolgáltatások. ${ }^{412}$ A WTO vitarendezési testülete több alkalommal is szembe találta magát a tagállamok között felmerülő olyan esetekkel, amelyek kifejezetten környezetvédelmi vonatkozásokkal rendelkeztek. Az ügyek általában az importtilalom kapcsán merültek fel, mint garnélarák-tengeri teknős ${ }^{413}$ vagy a tonhal-delfin ${ }^{414}$ ügyekben.

\footnotetext{
${ }^{409}$ WTO Green Provisions

https://www.wto.org/english/thewto_e/whatis_e/tif_e/bey2_e.htm (2019.02.06.).

${ }^{410}$ United States - Import Prohibition of Certain Shrimp and Shrimp Products (USA v India, Malajzia, Thaiföld, Pakisztán) DS58.

${ }^{411}$ Roberto Azevêdo: WTO igazgatója in: CITES and WTO Enhancing Cooperation for sustainable Development. WTO Titkárság, Svájc, 2015. 4.p. [Továbbiakban: CITES and WTO].

412 The environment: a specific concern

https://www.wto.org/english/thewto_e/whatis_e/tif_e/bey2_e.htm (2019.02.04.).

${ }^{413}$ United States - Import Prohibition of Certain Shrimp and Shrimp Products (USA v India, Malajzia, Thaiföld, Pakisztán) DS58.

${ }^{414}$ United States - Measures Concerning the Importation, Marketing and Sale of Tuna and Tuna Products (USA v Mexico) DS381.
} 
Mivel jelen értekezésnek nem célja a WTO környezetvédelemmel kapcsolatos rendelkezéseinek és joggyakorlatának elemzése, azok nem kerülnek részletesen kifejtésre. Általában véve megállapítható, hogy a WTO alapvetően nem környezeti, hanem kereskedelmi szervezet, amely az 1980-as évektől kezdődően egyre inkább szembekerül a környezetvédelem és a kereskedelmi érdekek ütközésének problémájával. A téma szempontjából a WTO keretében kidolgozott szankciók kérdése és a CITES által alkalmazott kereskedelmi felfüggesztések összeütközésének problémája jelentős. Továbbá, a téma szempontjából meg kell határozni a WTO és a multilaterális környezeti megállapodások kereskedelmi rendelkezéseinek kapcsolatrendszerét.

Jelenleg 250 multilaterális környezeti megállapodás van hatályban, amelyböl húsz a kereskedelem kontrollján keresztül valósítja meg a célkitüzéseit. A WTO utóbbi MEAs-el tart fenn állandó együttmüködést és monitorizálja azok kereskedelemmel kapcsolatos döntéseit, amelyeket egy kétévente felülvizsgálatra kerülő ún. Mátrix rendszerben követhető módon tesznek közzé. Az első Mátrix elfogadására 2001-ben került sor, amelyet legutóbb 2017 októberében vizsgáltak felül. ${ }^{415}$ Az együttmüködésben részvevő megállapodások körébe tartoznak többek között ${ }^{416}$ a CITES, a Biológiai Sokféleség Egyezményhez füzött Cartagena Jegyzőkönyv, ${ }^{417}$ a Klímaváltozási Keretegyezmény, a Kiotói Jegyzőkönyv és a Párizsi Klímamegállapodás, ${ }^{418}$ a Bázeli egyezmény a veszélyes hulladékok országhatárokat átlépő szállításának ellenőrzéséről és ártalmatlanításáról, ${ }^{419}$ és a Stockholmi Egyezmény a környezetben tartósan megmaradó szerves szennyező anyagokról. ${ }^{420}$ A környezeti kérdések integrálását segíti 1995 óta a WTO Környezeti Adatbázisa ${ }^{421}$ Az adatbázis tartalmaz minden, a WTO tagállamok által benyújtott, környezeti tárgyú érte-

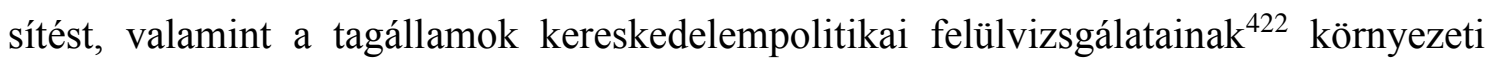

\footnotetext{
415 WTO Mátrixok: https://docs.wto.org/dol2fe/Pages/FE_Search/FE_S_S006.aspx?DataSource=Cat\&query=@Symbol=WT/CTE/W/160/*\&Language=English\&Context=ScriptedSearches\&languageUIChanged=true (2019. 02.05.)

Legutóbbi Mátrix: TN/TE/S/5/Rev.6; WT/CTE/W/160/Rev.8 [Továbbiakban: Mátrix 2017.].

${ }^{416}$ Teljes lista elérhető az alábbi linken:

WTO Matrix on Trade-Related Measures Pursuant to Selected Multilateral Environmental Agreements $(M E A s)$ https://www.wto.org/english/tratop_e/envir_e/envir_matrix_e.htm (2019.02.05.).

417 Cartagena Protocol on Biosafety to the Convention on Biological Diversity. UNTS vol. 2226, 208. p. 2000. (2003.).

${ }^{418}$ United Nations Framework Convention on Climate Change (UNFCCC), UNTS vol. 1771, p. 107. 1992. (1994.) the Kyoto Protocol UNTS vol. 2303, p. 162. 1997. (2005.) and the Paris Agreement 2015. (2016.) ${ }^{419}$ Basel Convention on the Control of Transboundary Movements of Hazardous Wastes and their Disposal UNTS vol. 1673, p. 57. 1989. (1992.).

${ }^{420}$ Stockholm Convention on Persistent Organic Pollutants UNTS vol. 2256, p. 119. 2001. (2004.).

${ }^{421}$ WTO EDT: WTO Environmental Database.

422 Trade Policy Reviews.
} 
rendelkezéseit és politikáját. Az adatbázis csaknem ötezer környezeti tárgyú értesítést, több mint tízezer környezeti tárgyú intézkedést és több mint hétezer környezeti tárgyú kereskedelempolitikai felülvizsgálati szegmenst tartalmaz. ${ }^{423}$ 2017-ben az értesítések 3,5 százaléka volt CITES-el kapcsolatos, amely kb. 130 jelzést takar. ${ }^{424}$

A CITES 1973-ban került aláírásra, 1975-ben lépett hatályba, a WTO és a jelenlegi nemzetközi kereskedelmi jogi rendszer az 1990-es évek elejéhez kötődik. 1960-as évektől kezdődő CITES szövegezési folyamat során is egyértelmü volt, hogy a WTO elödjével, az 1947 óta létező GATT-tal összhangot kell teremteni. Már csak abból a szempontból is, hogy a vadvilági kereskedelemhez szükséges engedélyek és dokumentációk nem pénzügyi jellegü kereskedelmi akadályt képezhetnek. A két szervezet között mindig is szoros együttmüködés volt, amely nélkülözhetetlennek tekinthető az egyes kereskedelmi szektorok összefonódása miatt. Azonban a korai időszakban a kooperáció leginkább az GATT-ban és a CITES-ben is részes fél államok egymás közötti értesítéseiben merült ki, a CITES dokumentációs követelményekre vonatkozóan. ${ }^{425}$

A 2014-ben aláírt TFA ${ }^{426}$ megállapodás, amely kifejezetten a fejlődő és a legkevésbé fejlett országok segítését célozza meg, további lehetőséget nyit a két szervezet közötti együttműködésre. A megfelelő kereskedelemkönnyítések ajtót nyitnak a kooperációnak, amely célja a gazdasági és társadalmi előnyök, a természetvédelmi célkitűzések és a fenntartható használat elérése. ${ }^{427}$ Végig tekintve a TFA részletszabályait, több ponton is megkönnyíti a CITES szabályok tagállami megvalósítását. Rendelkezik a kereskedelemhez szükséges okmányok és dokumentumok elismeréséről, ${ }^{428}$ az államok közötti információmegosztás lehetőségeiről, ${ }^{429}$ a határügynökségek és a vámhatóságok ${ }^{430}$ együttmüködéséröl is.

A CITES keretében több szinten sor kerülhet kereskedelmi jellegü intézkedések meghozatalára. A döntéshozatali szint alapján különbséget tehetünk:

\footnotetext{
${ }^{423}$ WTO EDT https://edb.wto.org/ (2019. 02. 05.).

${ }^{424}$ WT/CTE/EDB/17 2018. november 17.

${ }^{425}$ CITES and WTO 5.p.

${ }^{426}$ TFA: Trade Facilitation Agreement, Kereskedelem Könnyítő Megállapodás, elfogadta a WTO Általános Tanácsa 2014 novemberében. A megállapodás 2017. február 22-én lépett hatályba. Ez az első megállapodás, amelye a WTO keretében fogadtak el és minden tagállam támogatását elnyerte. See: https://www.wto.org/english/thewto_e/20y_e/wto_tradefacilitation_e.pdf (2019. 02. 03.) [Továbbiakban: TFA].

${ }^{427}$ CITES and WTO, 1. p.

${ }^{428}$ TFA 10. cikk.

429 TFA 1. cikk.

430 TFA 8. és 12 . cikkek.
} 
- kötelező erővel bíró kereskedelmi intézkedések (amelyek az Egyezmény szövege alapján kerülnek elfogadásra);

- a részes felek konferenciáin elfogadott kereskedelmi intézkedések;

- a részes felek konferenciája helyett, az Állandó Bizottság által elfogadott kereskedelmi intézkedések;

- a Növény és az Állat Bizottságok által elfogadott kereskedelmi intézkedések;

- a Titkárság által a CoP-nek vagy az Állandó Bizottságnak ajánlott kereskedelmi intézkedések között, valamint meg kell említeni a

- részes felek által elfogadott szigorúbb belső szabályozás kérdését. ${ }^{431}$

Már korábban említésre kerültek az Egyezmény szabályai alapján elfogadható kereskedelmi intézkedések, így röviden utalva azok jogi alapjára: a III-IV-V. Cikkek foglalkoznak a három különböző védelmet biztosító függelék alapján hozható rendelkezésekkel. A IV. Cikk rendezi az engedélyek és bizonyítványok kérdését, a VII. Cikk a kivételeket és más különleges rendelkezéseket, a VIII. Cikk a felek által foganatosítható intézkedéseket, a IX. Cikk az Igazgatási és Tudományos Hatóságokat, és végül a XIV. Cikk a belső jogalkotásra és nemzetközi egyezményekre gyakorolt hatást. A részes felek konferenciáin kiterjedten foglalkoztak a kereskedelemre hatást gyakorló, vagy kifejezetten kereskedelmi intézkedésekkel.

A részes felek konferenciáin foglalkoztak a korlátozások lehetőségével is. Először 1987ben, az Ottawában megrendezett CoP-n fogadtak el egy értelmezéssel kapcsolatos határozatot, amely az Egyezmény szigorúbb belső intézkedésekre vonatkozó rendelkezéseire vonatkozik. ${ }^{432}$ 1994-ben Fort Lauderdaleben (Amerikai Egyesült Államok) az I. Függelékbe sorolt fajokra vonatkozó kvóták értelmezése és alkalmazása körében született döntés. ${ }^{433}$ Néhány évvel később újra terítékre kerültek a kvóták, amikor a Hararéban (Zimbabwe) megrendezett konferencián kifejezetten a személyes használatra szánt leopárdtrófeákra és bőrökre alkalmazott kvótákról határoztak. ${ }^{434}$ Ugyancsak 1997-ben az élő példányok és egyedek szállításával kapcsolatos rendelkezésekről is tárgyaltak. Utóbbiakkal összefüggésben különösen fontos a Nemzetközi Légi Szállítási Szövetség által kidolgozott iránymutatások ${ }^{435}$ figyelembevétele a légi és a CITES javaslatok megfontolása a nem

\footnotetext{
${ }^{431}$ Mátrix 2017. 9. p. Trade-related Measures.

${ }^{432}$ Res. Conf. 6.7 Interpretation of Article XIV, paragraph 1, of the Convention.

${ }^{433}$ Res. Conf. 9.21 (Rev. CoP13) Interpretation and application of quotas for species included in Appendix I.

${ }^{434}$ Res. Conf. 10.14 (Rev. CoP16) Quotas for leopard hunting trophies and skins for personal use.

${ }^{435}$ IATA Live Animal Regulations (állatokra) és IATA Perishable Cargo Regulations (növényekre).
} 
légi szállítás során. Az ezredfordulón Gigiriben (Kenya) rendezett CoP-n foglalkoztak a pézsmaszarvasok egyre nagyobb mértékü illegális kereskedelmével. ${ }^{436}$ Santiagóban (Chile) 2002-ben több határozat is mérvadó a témakörrel kapcsolatosan. Először is egyes halfajok megörzéséről és kereskedelméről, ${ }^{437}$ másodsorban a II. Függelékbe sorol fajok jelentős kereskedelmére vonatkozó szabályokat vizsgálták felül. ${ }^{438}$ 2004-ben Bangkokban (Thaiföld) ült össze a $\mathrm{CoP}$, ahol több soron napirendre tüzték a kereskedelemmel kapcsolatos rendelkezéseket: a biodiverzitás fenntartható használatát, különös tekintettel az Addis Ababa-i elvekre; ${ }^{439}$ az emberszabású majmok megőrzését és kereskedelmét; ${ }^{440}$ a fekete rinocérosz trófeák export kvótáinak felállításáról; ${ }^{441}$ valamint az idegen invazív fajok kereskedelméről. ${ }^{442}$ 2007-ben Hágában (Hollandia) tartották a részes felek konferenciáját, ahol határoztak a CITES és a Nemzetközi Trópusi Erdő Szervezet ${ }^{443}$ közötti, trópusi faanyagra vonatkozó együttmüködésről, ${ }^{444}$ a tengerből történő bevételröl ${ }^{445}$ és a nemzeti szinten meghatározott kiviteli kvóták menedzsmentjéről. ${ }^{446}$ 2010-ben, Dohában vizsgálták felül a vadvilági kereskedelmi politikát, felhívva a figyelmet a releváns társadalmi, környezeti és gazdasági hatások figyelembevételére. ${ }^{447}$ 2013-ban újra Bangokban találkoztak a részes felek, ahol több kérdéskörben is tárgyaltak kereskedelmi vonatkozású témákat. Elfogadták a CITES Stratégiai Vízió 2008-tól 2020-ig tartó programját, ${ }^{448}$ foglalkoztak a CITES és a megélhetés kapcsolatával, ${ }^{449}$ a nem hátrányos megállapításokkal, ${ }^{450}$ a zenei hangszerek nem kereskedelmi célú, gyakori, határt átlépő mozgásával ${ }^{451}$ és az Egyezmény végrehajtásával az agarfa tekintetében. A 2019-ben megrendezésre kerülő 18. CoP előtt utoljára 2016 őszén tartottak konferenciát a dél-afrikai Johannesburgban. A 17. konferencián számos határozatot hoztak, amelynek van kereskedelmi jelentősége. Az illegális kereskedelem leküzdésével kapcsolatosan tárgyaltak a keresletcsökkentési

\footnotetext{
${ }^{436}$ Res. Conf. 11.7 Conservation of and trade in musk deer.

${ }^{437}$ Res. Conf. 12.7 (Rev. CoP 17) Conservation of and trade in sturgeons and paddlefish.

${ }^{438}$ Res. Conf. 12.8 (Rev. CoP 17) Review of Significant Trade in Specimens of Appendix-II species.

${ }^{439}$ Res. Conf. 13.2. (Rev. CoP 14) Sustainable Use of Biodiversity: Addis Ababa Principles and Guidelines.

${ }^{440}$ Res. Conf. 13.4 (Rev. CoP 16) Conservation and trade in great apes.

${ }^{441}$ Res. Conf. 13.5 (Rev. CoP 14) Establishment of export quotas for black rhinoceros hunting trophies.

${ }^{442}$ Res. Conf. 13.10 (Rev. CoP 14) Trade in Alien Invasive Species.

443 ITTO: The International Tropical Timber Organization.

${ }^{444}$ Res. Conf. 14.4 Cooperation between CITES and ITTO regarding trade in tropical timber.

${ }^{445}$ Res. Conf. 14.6 (Rev. CoP 16) Introduction from the sea.

${ }^{446}$ Res. Conf. 14.7 (Rev. CoP 15) Management of nationally established export quotas.

${ }^{447}$ Res. Conf. 15.2 (Rev. CoP 15) Wildlife Trade Policy Reviews.

${ }^{448}$ Res. Conf. 16.3 (Rev CoP 17) CITES Strategic Vision: 2008-2020.

${ }^{449}$ Res. Conf. 16.6 (Rev. CoP 17) CITES and livelihoods.

${ }^{450}$ Res. Conf. 16.7 (Rev. CoP17) Non-detriment findings.

${ }^{451}$ Res. Conf. 16.8 (Rev. CoP 17) Frequent cross-border non-commercial movements of musical instruments.
} 
stratégiákról, ${ }^{452}$ és a jogellenes kereskedelem tárgyaként szolgáló és elkobzott CITES által listázott fajok kezeléséről. ${ }^{453}$ A megfelelés tekintetében az Egyezmény megsértéséből fakadó egyes tevékenységek tiltásáról, megelőzéséről, feltérképezéséről és a korrupció visszaszorításáról határoztak. ${ }^{454} \mathrm{~A}$ fogságban született és nevelt egyedek tekintetében a meghatározott forráskódok $(\mathrm{C}, \mathrm{D}, \mathrm{F}$ és $\mathrm{R})$ alatt, kereskedelmi tevékenység tárgyát képző példányokkal kapcsolatosan is határozatot fogadtak el. ${ }^{455}$ További döntések születtek az I. és II. Függelékekben szereplő fajok trófeáiról, ${ }^{456}$ a tobzoska ${ }^{457}$ és a kalapácsfejü szarvascsőrü madár megőrzéséről és kereskedelméről, ${ }^{458}$ valamint a kígyók megőrzéséről és fenntartható vadászatról. ${ }^{459}$

A WTO szankciós rendszerének fő alapja a „Vitarendezés szabályairól és eljárásáról szóló egyetértés", ${ }^{460}$ amelyet a WTO-t létrehozó Marrakeshi Egyezményhez füzött 2. sz. melléklet tartalmaz. A vitarendezési testülethe ${ }^{461}$ abban az esetben lehet fordulni, ha az ajánlásokat és határozatokat ésszerü időtartamon belül nem hajtják végre. A felek által alkalmazható „ideiglenes intézkedések” a következőket foglalják magukba: kompenzáció és engedmények vagy más kötelezettségek felfüggesztése. ${ }^{462}$

A kötelezettségek egy olyan általános terminus technikus, amit a WTO-megállapodásokban használnak az egyszerüség kedvéért. Azonban ennek leggyakoribb formája az engedmények felfüggesztése, amelyhez a DSB előzetes felhatalmazása szükséges. Az eredeti, angol nyelvü szövegezés a „,countermeasures” szót használja mindazon „,megtorló intézkedések” vagy „szankciók” leírására, amelyek egy másik állammal szemben kerülnek alkalmazásra. A countermeasures kifejezést magyarra ellenintézkedésnek fordítjuk. Utóbbi intézkedések egyéb esetekben összeférhetetlenek lennének a WTO szabályrendszerével.

\footnotetext{
${ }^{452}$ Res. Conf. 17.4 Demand reduction strategies to combat illegal trade in CITES-listed species.

${ }^{453}$ Res. Conf. 17.8 Disposal of illegally traded and confiscated specimens of CITES-listed species.

${ }^{454}$ Res. Conf. 17.6 Prohibiting, preventing, detecting and countering corruption, which facilitates activities conducted in violation of the Convention.

${ }^{455}$ Res. Conf. 17.7 Review of trade in animal specimens reported as produced in captivity.

${ }^{456}$ Res. Conf. 17.9 Trade in hunting trophies of species listed in Appendix I or II.

${ }^{457}$ Res. Conf. 17.10 Conservation of trade in pangolins.

${ }^{458}$ Res. Conf. 17.11 Conservation of and trade in helmeted hornbill.

${ }^{459}$ Res. Conf. 17.12 Conservation, suatainable use of and trade in snakes.

${ }^{460}$ Understanding on Rules and Procedures Governing the Settlement of Disputes. Vitarendezés szabályairól és eljárásáról szóló egyetértés. https://www.wto.org/english/docs_e/legal_e/28-dsu.pdf [Továbbiakban: Vitarendezési egyetértés]

461 Angol nyelvü terminológiában: „DSB: Dispute Settlement Body”.

${ }^{462}$ Vitarendezési egyetértés, 22 . cikk 1. pont.
} 
Ilyen jellegü szankciókhoz csak végső esetben, a súlyos következményt eredményező meg nem felelés esetén lehet alkalmazni a vitarendezési egyetértés alapján. ${ }^{463}$ A vita tárgya, hogy az ideiglenes intézkedések voltaképpen a megfelelés elösegítésének eszközei, vagy pusztán a kölcsönös kereskedelmi előnyök kiegyensúlyozását biztosítja. Mindazonáltal a DSU folyamatosan figyelemmel kíséri a szankcióval sújtott részes államot, és amennyiben újra megfelel a követelményeknek, azonnal meg kell vele szemben szüntetni a hátrányos kereskedelmi intézkedéseket. Így voltaképpen a megtorló intézkedések célja elsősorban a megfelelés biztosítása és annak helyreállítása. Pontosan a megtorló intézkedések kivételes jellege miatt egy általános feltételnek meg kell felelnie a szankcióknak: ugyanabban a szektorban kell alkalmazni, ahol a sérelem vagy egyenlőtlenség történt. ${ }^{464}$

Megvizsgálva tehát a CITES és WTO szankciós rendelkezéseinek összehangját, a következő következtetések vonhatók le. A probléma elsősorban azon államok esetében merülnek fel, amelyek mind a CITES-ben, mind pedig a vonatkozó kereskedelmi megállapodásban részes felek. Jelenleg ez olyan kérdés, amelyet a részes felek szinte „hallgatással” orvosolnak, mivel a DSU előtt soha, egyetlen állam sem indított eljárást egy, a veszélyeztetett fajok kereskedelmére vonatkozó, megtorló vagy hátrányos intézkedés alkalmazása miatt.

Gondolati síkon alapvetően ezek a CITES által alkalmazott kereskedelmi felfüggesztések legtöbbször - véleményem szerint - megfelelnek a WTO megtorló intézkedéseivel szemben támasztott követelményeknek. A kereskedelmi felfüggesztések, embargó bevezetésére a veszélyeztetett fajok kereskedelme és azzal kapcsolatos problémák miatt, ugyanabban a szektorban kerülnek bevezetésre. Ha a részes fél újra megfelel a követelményeknek - általában a kereskedelmi felfüggesztések egy éven belül feloldhatók - azonnal viszszavonásra kerülnek. És végső soron azok vagy a részes felek konferenciáinak, vagy az Állandó Bizottság ajánlásai alapján kerülnek alkalmazásra. Más kérdés az egyes államok által, más államokkal szemben alkalmazott, nemzeti hatáskörben hozott embargós intézkedések hatása. Végső soron azt a következtést vonhatjuk le, hogy nem teljesen elrugaszkodott rendszer a CITES alapján hozott kereskedelmi felfüggesztések köre, azonban a

\footnotetext{
${ }^{463}$ Vitarendezési egyetértés, 3. cikk 7. pont „A kompenzációs rendelkezéshez csak akkor lehet fordulni, ha az intézkedés azonnali visszavonása gyakorlatilag megvalósithatatlan, illetve ideiglenes intézkedésként, az idetartozó egyezménnyel összhangban nem álló intézkedés visszavonásáig. A jelen Egyetértés a vitarendezési eljárást felhívó Tag számára végső lehetőségként az idetartozó egyezmények szerinti engedmények vagy más kötelezettségek diszkriminatív módon történő felfüggesztését teszi lehetövé a másik Taggal szemben, függöen attól, hogy a DSB az ilyen intézkedést jóváhagyja-e."

464 The process - Stages in a typical WTO dispute settlement case. https://www.wto.org/english/tratop_e/dispu_e/disp_settlement_cbt_e/c6s10p1_e.htm (2019.02.06.).
} 
jövőben nem elképzelhetetlen annak DSU előtti megmérettetése. Vajon a környezeti kérdéseket egyre inkább elötérbe helyezö WTO milyen döntést hozna egy ilyen, a nemzetközi kereskedelmi jogot és a környezeti érveket mérlegre helyezö vitában?

Noreena Hertz mondta, hogy „WTO egy olyan szervezet, amely a kereskedelmi értékeket védi....A környezet és az emberi jogok védelmére mindenképpen szükség van egy ellensúlyra." ${ }^{465}$

Tovább gondolva, vajon ezek az ellensúlyok megvalósíthatók-e a WTO rendszerén belül is? Leszükítve a kérdést a vadvilágból származó egyedekkel és termékekkel folytatott kereskedelmi tevékenységre, ésszerü megoldásnak tünik, hogy a már létező két szervezetrendszer, a CITES és a WTO együttmüködése valósuljon meg. Azonban a kereskedelmi intézkedések és elfogadott szabályok esetében mindenképpen tekintettel kell lenni a környezetvédelmi érdekek hatékonyabb képviseletére. Jelenleg viszonylag széles körü kooperáció alakult ki a kereskedelmi tárgyú nemzetközi környezeti egyezmények és a Kereskedelmi Világszervezet között. Azonban, véleményem szerint, a multilaterális környezeti egyezmények „döcögő”, nem zökkenőmentes érvényesülése mindenképpen rányomja a bélyegét a velük kapcsolatos minden egyéb együttmüködési kérdésre is. Így érdemes megvizsgálni a kérdést, hogy a környezetpolitikai hiányosságok, szabályozási elégtelenségek nem inkább a nemzetközi és a nemzeti környezeti szabályozás hiányosságaiból adódik-e inkább, mint a kereskedelmi globalizáció hátrányaiból. Ha a válasz igen, akkor a WTO-t és más kereskedelmi szervezeteket, mint a „rossz hír hozóját” hibáztatja a világ a környezeti hátrányokért, mintsem megoldást keresnének a tényleges, alapot képző problémákra. Bár a szabadkereskedelem és a liberalizáció környezeti hatásai vitathatatlanok, ne felejtsük el, hogy amit a szabályozás nem enged meg, az tilalmazott és jogellenesnek minősül. Ha a környezeti érdekek valódi képviseletre kerülnek egy kereskedelmi tárgyalási folyamatban, akkor a későbbi negatív hatások nem feltétlenül abból erednek, hanem inkább a környezetminőségre fordított figyelem csekély voltából és a hatékony védelmi eszközök hiányából.

\footnotetext{
465 Noreena Hertz (London, 1967-), közgazdász, akadémikus, író.

Idézet forrása: Transcript - Bill Moyers Interviews Noreena Hertz. https://www.pbs.org/now/printable/transcript_hertz_print.html (2019.08.10.)

„Well, the World Trade Organization is an organization that defends trade interests. I think the problem is less that they exist. The problem is that internationally we've only got an organization that protects trade interests. Surely we need some kind of counterweight to protect human rights and the environment too."
} 


\section{IV.4. A hátrányos jogkövetkezmények alkalmazása}

A vadvilággal kapcsolatos büncselekmények sorának van nemzetközi jelentősége. Azonban ezen cselekmények elbírálásának lehetősége állami kereteken belül marad és amíg nem kerül létrehozásra az önálló, környezeti nemzetközi bűncselekményi kategória, ebben nem is lehet jelentős változásra számítani. Felmerül, hogy a Washingtoni Egyezmény vagy az Európai Unió vadvilági rendeleteinek megszegése milyen felelősségrevonást vonjon maga után. Hiszen a bűncselekményi minősítés megállapítása sokáig nem volt egyértelmü az érintett cselekmények körében.

A CITES VIII. Cikke a „Részes felek által foganatositásandó intézkedések” körében a Függelékekben listára vett fajok példányai kereskedelmének vagy birtoklásának vagy mindkettőnek a „hátrányos jogkövetkezményekkel” való sújtására kötelezi az államokat, ha az nem fér össze az Egyezmény rendelkezéseivel. Továbbá, specifikusan az elkobzást emeli ki. ${ }^{466}$ A hátrányos jogkövetkezmények kifejezés nem egyenlő a büntetni rendeléssel, így az kimerülhetne a pénzügyi hátrány vagy más enyhébb jogkövetkezmény alkalmazásában. A CITES Titkárság javaslatokkal és a részes felek konferenciáin elfogadott határozatokkal igyekszik segíteni a nemzeti jogalkotást. Kialakításra került egy olyan „modell jogi szabályozás”, amely segítséget nyújthat a belső jog fejlesztéséhez, az Egyezménynek való megfelelés eléréséhez. A vonatkozó dokumentumban is megállapításra került, hogy hogy a CITES tárgykörébe tartozó fajok illegális kereskedelme többféle jogi szankciót vonhat maga után: különösen büntetőjogi, vámjogi és kereskedelmi jogi, így különösen fontos specifikusan meghatározni, hogy melyik jogkövetkezmény vonatkozik kifejezetten a CITES szabályainak megsértésével elkövetett cselekményekre. ${ }^{467}$ Továbbá, a példaként szolgáló jogszabály kapcsán is megállapításra kerül, hogy jogellenes cselekmények eredményezhetnek közigazgatási, polgári jogi és büntetőjogi felelősséget és jogkövetkezményeket is. ${ }^{468}$

Bizonyos tényezők indikálják azt, amiért a büncselekményi minősités megalapozottnak tekinthető. Elsősorban, a cselekmények motivációja tisztán profitorientált, nem pusztán szabályozás megkerülése a cél. Továbbá, a cselekmények kivitelezése nagy részben gátlástalan kereskedők és terjesztők remélt magatartására támaszkodik. Ezt egészíti ki, hogy

${ }^{466}$ CITES VIII. cikk (1) bekezdés a) és b) pontok.

${ }^{467}$ Model Law on International Trade in Wild Fauna and Flora. CITES Secretariat, 4. p. https://cites.org/sites/default/files/eng/prog/Legislation/E-Model\%20law-updated-clean.pdf $\quad$ (2019. 08. 09.) [Továbbiakban: Model Law]

${ }^{468}$ Model Law, 16. p. 
nem pusztán gondatlan vagy vétlen jogsértésekről van szó, hanem az elkövető tudata átfogja, hogy büncselekményt követ el, annak a megtörténtét kívánja. Különösen nagy jelentőséggel esik latba, hogy az esetek jelentős részében a korábbi bünelkövetés is felmerül, valamint egyre inkább begyürüzik a szervezett bünözési elem, amely megnehezíti nem csak a cselekmények leleplezését, hanem a felderítést is. ${ }^{469}$ Az, hogy a CITES és az EU vadvilági rendeleinek megsértését miként szankcionálja egy állam, annak egyedi döntésén alapul és a belső jog határozza meg. Különösen fontos, hogy az igazságszolgáltató szervezetrendszerben legyenek olyan felkészült személyek, akik megfelelő szaktudással rendelkeznek a bűncselekmények megítéléséhez, az ilyen eljárásokban való részvételhez. Természetesen a vadvilággal kapcsolatos büncselekmények esetében nem pusztán az Egyezmény vagy pedig a rendeletek szabályainak megkerülése vagy megsértése merül fel. Azonban az államok jogában alkalmazott jogkövetkezmény gyakran használatos formájaként tekinthetünk az elkobzásra. Elkobzásra akkor kerül sor, ha a csempészáru a végrehajtó hatóságok látókörébe kerül. A vadvilági bünözés esetében különös fontossággal bír az elkobzott termékek mennyiségére és minőségére vonatkozó információ. Bár gyakran önmagában véve az elkobzásra vonatkozó információk megtévesztő eredményhez vezethetnek, más adatokkal összevetve és kombinálva az illegális piacok természetére vonatkozó értékes forrásként szolgálhatnak. A nagy mennyiségű csempészáru lefoglalása nem utal az adott államban müködő végrehajtó hatóságok gyenge müködési hatékonyságára, hanem éppen ennek ellenkezőjére. A vadvilági kereskedelmi útvonalak felderítésében így különös jelentőséggel bírnak az elkobzások során nyert adatok. ${ }^{470}$

A kapcsolódó büncselekmények körében felmerül: okirathamisítás, csempészet és vámszabályok megsértése, adó, import-export kötelezettségek és devizaszabályok megkerülése, karantén, emberi-, állat- vagy növényegyészségügyi rendelkezések megsértése, bevándorlásra vonatkozó rendészeti szabályok megsértése, lőfegyverrel való visszaélés, megvesztegetés és korrupció, csalás, szervezett bünözés, zsarolás és egyéb maffiatevékenység, bünszövetkezetek létrehozása (összeesküvés), és végül a megszerzett anyagi eszközök mentése, pénzmosás és más kapcsolódó cselekmények. ${ }^{471}$ Utóbbiak köre különkülön is büntetni rendelt az egyes államok belső joga szerint, azonban a specialitást és

\footnotetext{
${ }^{469}$ Sellar, JoHn M.: Investigating and Prosecuting Wildife Crime. How to enforce EU legislation on biodiversity and wildlife trafficking 2016. 3. p. [Továbbiakban: SELLAR, 2016.]. http://ec.europa.eu/environment/legal/law/4/pdf/investigation_and_prosecution_of_wildlife_crime.pdf. ${ }^{470}$ World Wildlife Crime Report, Trafficking in protected species. UNODC, United Nations, New York, 2016. 28. p.

${ }^{471}$ SELLAR, 2016. 41. p.
} 
ezzel a nehézséget az okozza, hogy mindezen cselekmények a nehezen felderíthető vadvilággal kapcsolatos büncselekmények keretében kerülnek elkövetésre. Természetesen, a vadvilági kereskedelemre vonatkozó nemzetközi és uniós instrumentumok megsértése önmagában is büntetendő cselekménynek számít, azonban a büntetési tételek között jelentős különbségek vannak. Az Európai Unió tagállamaiban a vadvilággal kapcsolatos büntetendő cselekmények körét érintő több felmérés is készült, különös tekintettel a jogellenes vadvilági kereskedelem szempontjából kiemelt helyzetben, tranzit- vagy célállamként jelentőséggel bíró országokat tekintve.

Az Egyesült Királyságban 2005-ben egészítették ki azt a szabályozást, amely a CITES kikényszerítésére vonatkozik. A módosítással a büncselekményekért kiszabható maximális börtönbüntetés idejét 2 évről 5 évre emelték fel. A tényleges eljárások száma igen változatos volt, 2007 és 2008 között egy, 2009 és 2010 között huszonegy, 2011 és 2012 között négy, 2013 és 2014 között pedig tizennyolc bünvádi eljárást indítottak. Nem csak az eljárások száma, hanem a kiszabott szankciók is változatosságot mutattak. Így $500 £$ bírságot szabtak ki két gyürüs farkú maki interneten való eladásának kísérlete miatt. Egy másik ügyben kilenc hónapos büntetést szabtak ki, két évre felfüggesztve és csaknem 4 ezer $£$ költség megfizetésére kötelezték a terheltet, aki az Amerikai Egyesült Államokból és Ausztráliából csempészett madártojásokat és adta el azokat. Ténylegesen végrehajtandó börtönbüntetést szabtak ki egy olyan ügyben, ahol a terhelt rinocéroszszarvat kísérelt meg becsempészni Kínából és az Egyesült Államokból. Ugyancsak tényleges börtönbüntetés lett a vége annak az ügynek, ahol több mint $750 \mathrm{~kg}$ ritka és veszélyeztetett korallt és kagylót kíséreltek meg csempészni a vietnámi Ho Chi Minh-böl az Egyesült Királyságba. ${ }^{472}$

Az Európai Unió területén Hollandia ugyancsak kiemelt jelentőséggel bír a vadvilággal kapcsolatos büntetendő cselekmények terén, fontos cél- és tranzitállomása a vadvilágból származó növény- és állatfajoknak, termékeknek. A többi EU tagállamhoz viszonyítva relatíve elég magas az elkobzások aránya, elsősorban a hüllők, madarak, növények és a tradicionális ázsiai gyógyászat termékei tekintetében. Érdekes módon megállapításra került, hogy jelentős szervezett bünözői szálak nem kötődnek a Hollandiában megfigyelhető jogellenes kereskedelmi tevékenységhez. ${ }^{473}$ Ugyanakkor a drogcsempészet hagyományos módszereit felhasználva, a Hollandia területén megtalálható bünözői csoportok

\footnotetext{
${ }^{472}$ ILLES, ANDREA: Wildlife Crime in the United Kingdom. 2016. IP/A/ENVI/2015-10 11-12. p.

${ }^{473}$ VAN DER GRIJP, NICOLIEN: Wildlife Crime in the Netherlands. 2016. IP/A/ENVI/2015-10 7.p. [Továbbiakban: Wildlife Crime in the Netherlands].
} 
madarakat, üllőket csempésznek az ország területére és azonnal megélénkült az illegális kereskedelem, amikor egy influenzavírus miatt tilos lett a veszélyeztetett madarak behozatala. ${ }^{474}$ A holland büntetőjogi szabályozás elég szigorú szabályokat állapít meg, hiszen a büncselekmények esetében akár hat év szabadságvesztés és súlyos (81 ezer EUR, szervezeteknél 810 ezer EUR) pénzbüntetés is kiszabható és a jog ismeri az enyhébben minősülő cselekmények, valamint a közigazgatási szankciók körét is. ${ }^{475}$

További példaként említhető Spanyolország, mint a vadvilági termékek egyik európai belépési pontja, amely földrajzi elhelyezkedése, valamint a latin-amerikai országokkal való kereskedelmi kapcsolatai miatt is jelentőséggel bír. Spanyolország sokszor tranzitállamként szolgál a vadvilági termékek Közép-Keletre vagy Ázsiába történő tovább szállításakor, illetve egyes Spanyolországban honos állat- és növényfajok ${ }^{476}$ kedvelt célpontjai a vadvilági bünözésnek. Az elmúlt tíz évben több olyan müvelet is történt, amely a szervezett bünözői csoportok felszámolására irányult. Azonban a bünözés felszámolása továbbra is nagy kihívás elé állítja a spanyol hatóságokat, különösen, hogy az internet egy szinte lenyomozhatatlan piaci felületet biztosít a jogellenesen megszerzett vadvilági termékek értékesítésében. ${ }^{477}$ A spanyol hatóságok élen járnak a nem kormányzati szervezetekkel való együttmüködésben is, hiszen több megállapodás aláírására sor került, olyan egyedek gondozására is, amelyek származási országa nem állapítható meg vagy nem küldhetök vissza oda. ${ }^{478}$

Különösen a közép-európai jogellenes online kereskedelmet illetően, Lengyelország kiemelt államnak minősül, ugyanakkor jelentős végrehajtási problémák is megmutatkoznak az államban. Lengyelországban minden évben egyre romló tendenciát mutat az orvvadászat és a jogellenes kereskedelem. Bár a jogszabályozásban megjelenik a büncselekményi minősítés, a bírósági eljárások elkerülése érdekében az ügyek legtöbb esetben még nyomozati szakban lezárásra kerülnek. ${ }^{479}$

Németországban a vámhatóságok három különböző elkövetői csoportot különböztetnek meg: a turistákat, akik veszélyeztetett állatokból és növényekből készült szuveníreket visznek be az országba (kisebb jelentőségü büncselekménynek minősülnek); a hivatalos

\footnotetext{
${ }^{474}$ Wildlife Crime in the Netherlands, 10. p.

475 Wildlife Crime in the Netherlands, 13. p.

${ }^{476}$ Különös tekintettel a kétéltüekre és a ragadozó madarakra. Az ázsiai piacon nagy kereslet van a Spanyolországban honos sólyom-félékre és angolnákra.

${ }^{477}$ FAJARDA DEL CASILlO, TERESA: Wildlife Crime in Spain. IP/A/ENVI/2015-10. 2016. 8. p. [Továbbiakban: Wildlife Crime in Spain].

http://www.europarl.europa.eu/RegData/etudes/IDAN/2016/578962/IPOL_IDA(2016)578962_EN.pdf

${ }^{478}$ Wildlife Crime in Spain, 29. p.

${ }^{479}$ PAQUEL, KAMILA: Wildlife Crime in Poland. IP/A/ENVI/2015-10. 2016. 1-15. p.
} 
csempészeket, akik tevékenységében a szervezett bünözés elemei is azonosíthatók; és a különleges fajok gyüjtőit, például kaktuszgyüjtőket, akik nem kereskedelmi, hanem egyéni célzatból vásárolnak, sokszor saját utazásaik során veszélyeztetett fajokat. Németországban a legnagyobb jelentőséggel a turisták és az egzotikus állatokat, növényeket tartó személyek bírnak, azonban az ország az egyik legjelentősebb tranzitállomás a Közép- és Dél-Afrika, valamint a Kelet-, Dél-Kelet-Ázsia (elsősorban Kína és Vietnám) közötti elefántcsont-kereskedelemben. ${ }^{480}$ Annak ellenére, hogy a vám- és rendészeti hatóságok elég sikeresnek mondhatók a jogellenes tevékenységek felderítésében, valamint a jogszabályozás is megfelelőnek tekinthető, köszönhetően az elmúlt évek kiegészítéseinek, még sem beszélhetünk hatékony kikényszerítésröl. Németországban is nagy hátrányt jelent a megfelelő szaktudás hiánya, különösen a vádlói szinttől kezdődően, jelentősen csökkentve a vadvilágot károsító büncselekmények elleni fellépés hatékonyságát. ${ }^{481}$

Az előbbiekből jól leszürhető, hogy azon európai államokban, amelyek különösen ki vannak téve a vadvilággal kapcsolatos büntetendő cselekményeknek, a megfelelő szabályozást jelentősen gyengítik a szaktudásból és a végrehajtásból eredő hiányosságok.

A Magyar Büntetőkönyvről szóló 2012. évi C. törvény a természetkárositás tényállás ${ }^{482}$ keretében rendeli büntetni a vadvilági kereskedelemre vonatkozó szabályok megsértését, amely keretében az uniós jogforrásokra utal vissza. A büntetési tétel alapesetben három évig terjedő, a gondatlan alakzat esetén két évig terjedő és minősített esetben egy évtől öt évig terjedő szabadságvesztés. Az új Btk. hatálybalépése óta összesen egy ügy volt, ahol

480 STOERRING, DAGMARA: Wildlife Crime in Germany. IP/A/ENVI/2015-10. 2016. 8. p. [Továbbiakban: Wildlife Crime in Germany].

${ }^{481}$ Wildlife Crime in Germany 15. p.

482 Természetkárosítás 242. $\S$ (1) bekezdés.

,Aki

a) fokozottan védett élö szervezet egyedét,

b) védett élö szervezet vagy az Európai Unióban természetvédelmi szempontból jelentös növény-vagy állatfaj egyedeit, feltéve, hogy azok külön jogszabályban meghatározott, pénzben kifejezett értékének együttes összege eléri a fokozottan védett élö szervezet egyedei esetében megállapitott, pénzben kifejezett legalacsonyabb értéket,

c) a vadon élö állat- és növényfajok számára kereskedelmük szabályozása által biztositott védelemröl szóló EK tanácsi rendelet A és B melléklete hatálya alá tartozó élő szervezet egyedét

jogellenesen megszerzi, tartja, forgalomba hozza, az ország területére behozza, onnan kiviszi, azon átszállítja, azzal kereskedik, illetve azt károsítja vagy elpusztítja, büntett miatt három évig terjedö szabadságvesztéssel büntetendö.

(2) A büntetés egy évtöl öt évig terjedő szabadságvesztés, ha a természetkárositás az élö szervezet egyedeinek olyan mértékü pusztulását okozza,

a) hogy az (1) bekezdés a) vagy b) pontja esetében az elpusztitott élö szervezet egyedeinek külön jogszabályban meghatározott, pénzben kifejezett értékének együttes összege eléri a fokozottan védett élö szervezet egyedei esetében megállapitott, pénzben kifejezett legmagasabb érték kétszeresét,

b) amely az (1) bekezdés c) pontja esetében az élö szervezet állományának fennmaradását veszélyezteti.

(3) Aki a (2) bekezdésben meghatározott büncselekményt gondatlanságból követi el, vétség miatt két évig terjedö szabadságvesztéssel büntetendö." 
egy barnamedve trófeájának Magyarországra való hozatala kapcsán indítottak büntetőeljárást, azonban a vádlottat végül felmentették. ${ }^{483}$

A környezeti büncselekmények köre egyre nagyobb kihívás elé állítja az államokat. Az IUCN 2016-ban elfogadott határozatában nemzetközi és regionális szinten müködő szervezetek széles körét szólította fel, hogy vizsgálják felül a környezet elleni büncselekmények fogalmát és a vonatkozó jogi instrumentumokat. ${ }^{484}$ Egyre több regionális és helyi szinten tartott találkozó kerül megrendezésre kifejezetten azzal a céllal, hogy az igazságszolgáltatásban dolgozó ügyészeket, bírákat felkészítsék a vadvilággal büncselekményekkel kapcsolatos eljárások lefolytatására. 2018-ban Buthánban találkoztak az államok képviselői azzal a céllal, hogy a dél-ázsiai térségben erőteljesebb nemzeti és regionális együttműködés alakuljon ki a vadvilági büncselekmények felderítése és szankcionálása érdekében. A pozitív példák között is említhető Buthán, amely területének több mint fele védett nemzeti park. Intézkedéseik között megjelenik az informátorok jutalmazása, akár a cselekmények szankcionálásaképpen kiszabható bírságnak megfelelő összeggel. ${ }^{485}$ A vadvilággal kapcsolatos jogi jellegü információk megosztása érdekében került létrehozásra a WILDLEX, amely az IUCN által müködtetett adatbázis. A WILDLEX-en kereshetők az egyes államok bíróságainak döntései, a jogi szabályzás eszközei, valamint irodalmi források. Az adatbázisban korlátozott számban állnak rendelkezésre az államok bírósági döntési. Elsősorban az Amerikai Egyesült Államok, Kína, Nagy-Britannia és egyes afrikai államok joggyakorlata került feltöltésre, amelyek azonban kiemelkedő jelentőséggel bírnak, hiszen mindegyik említett államot nagy mértékben érintik a vadvilággal kapcsolatos büncselekmények. ${ }^{486}$

A vadvilággal kapcsolatos individuális büntetőjogi felelősség megállapítása a belső jog szerint történik. A jogesetek köre változatosságot mutat, azonban több eset is a mükincskereskedők tevékenységével kapcsolatos. Az antikvitások körében a kereskedők látóterébe kerülhetnek olyan mütárgyak, vagy akár nyers termékek, amelyek CITES védelem alatt álló fajokból készültek vagy olyan részeket tartalmaznak. Itt a legveszélyeztetettebb fajok köre jelentős, gondolva az elefántcsonttal díszített szobrokra, faragványokra, használati tárgyakra, a nagymacskák bőréből/szőréből készült díszítő elemekre, az elefántlábasztalkákra, trópusi fákból készült bútorokra. Mindenképpen körültekintőnek kell lenni,

\footnotetext{
${ }^{483}$ A Pécsi Ítélőtábla, mint harmadfokú bíróság. Bhar.I.3/2017/4. szám.

${ }^{484}$ IUCN Res. 078 2016. november 07. Crimes against the environment.

${ }^{485}$ Prosecuting wildlife crimes in South Asia

https://www.unodc.org/southeastasiaandpacific/en/2018/12/wildlife-trafficking/story.html (2019. 03. 16.)

${ }^{486}$ WILDLEX https://www.wildlex.org/ (2019. 03. 16.).
} 
de egyes mükincskereskedők kifejezetten védett fajokból készült, vadvilági termékek kereskedelmére specializálódtak. Emiatt egyre több személy kerül az igazságszolgáltatás látóterébe.

Az egyik legutóbbi eset egy kanadai antikvitás kereskedőt érintett, név szerint Xiao Ju Guant (Tony Guan), aki ellen 2014 júliusában emeltek vádat Manhattanben, mivel egy bünszövetkezet részeseként vadvilági termékeket csempészett, beleértve a rinocérosz szarvat, az elefántcsontot és a védett korallokat is. Guannak Richmondban (British Columbia) volt antikvitáskereskedése. Azután tartóztatták le, hogy két fedett FWS ügynöktől egy bronx-i (New York) raktárban két veszélyeztetett fekete rinocéroszszarvat vásárolt, 45 ezer USD-ért. A vásárlás után Guant és a tolmácsként közremüködő női kísérőjét az ügynökök egy postára fuvarozták, ahol a két szarvat tartalmazó csomagot a vádlott a Washington államban lévő Point Robertsbe adta fel. A csomagra ráírta, kézműves termék, amelynek értéke 200 USD. Guan azt mondta később, hogy vannak emberei, akik a határon átjuttatják az értékes csomagokat, mint azt már sokszor tették. A feltételezések szerint Guan és bűntársai összesen több mint fél millió USD értékben csempésztek különböző amerikai aukciósházaktól vásárolt rinocéroszszarvat, elefántcsontból készült szobrokat és korallokat. A módszerek között szerepelt a lebukás során alkalmazott csempészet, közvetlen postázás Kanadába, hamisított vagy nem létező okmányokkal, engedélyekkel. Elítélése esetén Guan a bünszövetkezetben való részvétel miatt öt évig terjedő, a vadvilággal kapcsolatos vádak miatt további tíz évig terjedő börtönbüntetéssel néz szembe. Ehhez adódik a minden termék esetében kiszabható 200 ezer USD vagy a büncselekmények eredményeként megszerzett hasznok kétszeresig terjedő bírság. ${ }^{487}$

Legújabban a Nemzetközi Büntetőbíróság is foglalkozott a környezeti tárgyú károkozással. Az Ügyészi Hivatal 2016-ban adta ki az ügyek kiválasztására és a prioritásokra vonatkozó szabályzatát. ${ }^{488}$ A Hivatal az államok megkeresése alapján keresi az együttmüködés lehetőségét és közremüködést ajánl a nemzeti jog alapján súlyosnak minősített büncselekményekkel kapcsolatosan. Utóbbiak közé sorolhatók: a természeti erőforrások jogellenes kiaknázása, fegyver- és emberkereskedelem, pénzügyi bűncselekmények és a

\footnotetext{
487 Justice News, Department of Justice Office of Public Affairs. Canadian Antique Dealer Charged with Trafficking Wildlife. 2014. július 29.

https://www.justice.gov/opa/pr/canadian-antique-dealer-charged-trafficking-wildlife (2019. 03. 18.)

488 Office of the Prosecutors. Policy paper on case selection and prioritisation. 2016. szeptember 15. [Továbbiakban: Policy Paper]

Elérhető: https://www.icc-cpi.int/itemsdocuments/20160915_otp-policy_case-selection_eng.pdf (2019. 03. 16.).
} 
környezetpusztítás. ${ }^{489}$ Az ügyek kiválasztásának szempontjai között is megjelenik a környezeti kár és a környezetpusztítás, amely sok esetben súlyos következményekkel jár a helyi közösségekre. Éppen ezért a cselekmények hatásaira tekintettel, a Hivatal fokozott figyelmet fog fordítani olyan cselekmények kivizsgálására, amelyek a környezet károsodását, a termőföldek illegális kisajátítását vagy a természeti erőforrások jogtalan kiaknázását foglalták magukba. ${ }^{490}$

Az ICC 2016-os állásfoglalása a környezeti ügyekről mindenképpen elöremutató, több szempontból is. Először is, jelenleg nincs speciálisan, a környezetjog területén hatáskörrel rendelkező nemzetközi bíróság és az elképzelések alapján nem is várható a közeljövőben, hogy azt sikerül megvalósítani. Másodsorban a nem állami szereplőknek - legyenek azok felperesi vagy alperesi pozícióban - rendkívül korlátozott a környezeti igazságszolgáltatáshoz való hozzáférési joga. Végül rendkívül fontos, hogy a környezet nemzetközi védelme az emberiség közös céljaként legyen meghatározva. ${ }^{491}$

Azonban ki kell emelni, hogy a Római Statútumban ${ }^{492}$ jelenleg nem szerepel a környezeti büncselekmény, mint olyan esetkör, amikor az ICC eljárhat. Ez azt jelenti, hogy az Ügyészi Hivatal bár vizsgálódásaikor és az ügyek kiemelése során figyelmet fordíthat a környezeti károkozásra, a termőföldek jogtalan kisajátítására és a természeti erőforrások jogtalan kiaknázására, azok önálló tényállásként nem szerepelhetnek az ICC előtt.

\footnotetext{
${ }^{489}$ Policy Paper, 5. p.

${ }^{490}$ Policy Paper, 14. p.

${ }^{491}$ Alessandra Lehmen: ICC To focus on environmental crimes: a landmark move for international environmental law. 2017. 03. 21.

https://www.expertguides.com/articles/icc-to-focus-on-environmental-crimes-a-landmark-move-for-international-environmental-law/arljgbwe (2019. 03. 18.).

492 Rome Statue of the International Criminal Court. 1998. (2002.) a Nemzetközi Büntetőbíróság Rómában, 1998. július 17-én elfogadott Statútuma.
} 


\title{
V. Az Európai Unió vadvilági kereskedelemre vonatkozó sza- bályozása
}

\author{
„Az illegális vadvilági kereskedelem büncselekmény, \\ összetett kiváltó okokkal és nagy kiterjedéssel, \\ amely fenyegeti ökoszisztémánkat és a jó kormányzást." ${ }^{\text {493 }}$
}

A világ fejlettebb térségieben élők azt gondolják, hogy a vadvilági kereskedelem nem érinti őket. De a valóságban a problémának részesei és részei vagyunk, amelyről az uniós polgárokat is meg kell győzni, ahogyan azt Mark Jones, a Szabadnak Született Alapítvány (Born Free Fund) igazgatója is kifejtette. Enrico Brivio az Európai Bizottság környezeti és tengeri ügyi szóvivője úgy fogalmazott, hogy Európa mindig is a vadvilági kereskedelem elleni harc frontvonalában volt és az új intézkedéseken keresztül ott is marad. ${ }^{494}$ Az Európai Unió vadvilági kereskedelemre vonatkozó szabályozásának elemző értékelését több tényező is indokolja.

Elsősorban az Európai Unió volt az első (és napjainkig az egyetlen) - a CITES fogalmai alapján - „gazdasági integrációs szervezet”, amely csatlakozott az Egyezményhez. Az európai államok egy része a kezdetektől részt vesz a vadvilági kereskedelem nemzetközi szabályozásában. Alig néhány évvel ezelőtt az Európai Unió is részes féllé vált a CITESben, így szignifikáns kérdéssé vált, hogy az EU-ban miként fog megvalósulni a vadvilági kereskedelem egységes szabályozása.

Másrészről az EU már a CITES-hez való csatlakozást megelőzően is széles körü és Egyezmény rendelkezéseinél több tekintetben szigorúbb szabályozási rendszert alakított ki a veszélyeztetett fajok kereskedelmét illetően, már az 1980-as évek közepén.

Továbbá, a vadvilággal kapcsolatos büntetendő cselekmények terén az Unió az egyik legfontosabb tranzit- és célállomás, amely a téma tárgyalása során szükségszerüen felveti, vajon az EU és tagállamai milyen lépéseket tettek az érintett cselekmények felszámolása

\footnotetext{
${ }^{493}$ Emma McClarkin, European Conservatives and Reformists Group, Egyesült Királyság, rapporteur. Idézet forrása: Using EU trade tools to combat wildlife trafficking. Press release. 2017. 03. 02. http://www.europarl.europa.eu/news/en/press-room/20170228IPR64299/using-eu-trade-tools-to-combatwildlife-trafficking (2019. 08. 10.)

„Illegal trade in wildlife is a crime with complex roots and wide dimensions that threatens our ecosystems, and good governance. We must do all we can to tackle this illegal activity and to ensure that future generations will not be deprived of the beauty and diversity of our environment"

494 Forrás: Irene Banos Ruiz: Europe, a silent hub of illegal wildlife trade. 2017. 01. 20. http://www.dw.com/en/europe-a-silent-hub-of-illegal-wildlife-trade/a-37183459 (2019. 02. 23.)

[Továbbiakban: Europe, a silent hub of illegal wildlife trade].
} 
és terjedésének megakadályozása érdekében. A természetet károsító büncselekmények kapcsán gyakran az a téves elképzelés él, hogy az csak a fejlődő vagy kevésbé fejlett államokat érinti. Az igazság ezzel szemben az, hogy az Európai Unió és tagállamai az egyik legnagyobb jelentőséggel bíró térség, ha a vadvilággal kapcsolatos, jogellenes tevékenységeket tekintjük. Az egyes tagállamok azonban nem egyenlö mértékben vannak kitéve a következményeknek, hiszen azok, amelyek a kereskedelem szempontjából behozatali vagy kilépő pontok, még nagyobb figyelmet kell, hogy fordítsanak a CITES és az uniós jogi normák végrehajtására.

További indokként hozható fel, hogy az uniós tagállamoknak mind a nemzetközi, mind az uniós normáknak megfelelő belső szabályozási rendszert kellett kiépíteniük, több tekintetben is kiegészítve és megváltoztatva a már érvényes állami jogot. Az Európai Unió tekintetében további kihívást jelentenek az újonnan csatlakozó államok, hiszen a belső piac bővülése és a külső határok áthelyeződése jelentős változásokat von maga után. A 10 új állam európai integrációhoz való csatlakozását 2004-ben széles körü elemzés előzte meg, amely kiterjedt a bővítés vadvilági kereskedelmi szabályozásra gyakorolt hatásaira is. A fő célkitűzés az volt, hogy a csatlakozó államok ne gyengítsék meg az egyébként hatékonyan működő kereskedelmi szabályozási rendszert. A felmérések ugyanakkor azt mutatták, hogy egyes államokban már a csatlakozást megelőzően is szigorúbb normák éltek a CITES végrehajtása érdekében, mint amit az uniós jogból fakadó kötelezettségek meghatároztak. Így a fejlesztéseknek leginkább az összehangolt végrehajtás, információs technológiai fejlesztés és szakképzés irányába kellett mutatniuk.

Bár a CITES szempontjából az Európai Unió nemzetközi jogi szempontból nem különbözik az állam részes felektől, az EU vadvilági kereskedelemre vonatkozó szabályozási rendszere önmagában is modellszerü, egységes rendszert alkot. Mivel az EU összes tagállama is részes fél az Egyezményben, ki kellett alakítani azon kereteket, amelyek lehetővé teszik az egységes, uniós álláspont képviseletét anélkül, hogy megfosztaná az egyes államokat saját véleményüktől, érdekeik érvényesítésétől.

Az Európai Unió számos politikai kötelezettséget vállalt a vadvilág megőrzése érdekében. Ezek közé tartozik az Európai Unió Fenntartható Fejlődés Startégiája, amely széles körü keretet biztosít a természeti erőforrások felelősségteljes hasznosításának és megköveteli, hogy a környezeti fenntarthatóság az EU külső politikájának is része legyen. ${ }^{495}$ A

495 Communication from the Commission A Sustainable Europe for a Better World: A European Union Strategy for Sustainable Development (Commission's proposal to the Gothenburg European Council) 2001. 05. 15. $\operatorname{COM}(2001) 0264$ final. 
Környezeti és Természeti Erőforrások Tematikus Programja ${ }^{496}$ az EU külső politikai cselekvési körének volt része és elsődleges céljaként a fejlődő államok és térségek támogatása került meghatározásra. Ezentúl az Európai Uniónak biodiverzitással kapcsolatos stratégiája ${ }^{497}$ és akcióterve ${ }^{498}$, jelentősen hozzájárulnak az európai térség sokféleségének megőrzéséhez és fenntartható használatához. A Stratégiában szerepel az együttmüködés és a szinergiák javítására, valamint a biológiai sokféleséggel kapcsolatos egyezmények közös prioritásainak meghatározása. Az egyezmények között szerepel a CITES is, azonban a veszélyeztetett fajok megőrzésére vonatkozó uniós cselekvés a Washingtoni Egyezményhez való csatlakozással teljesedett ki. ${ }^{499}$

A vadvilággal kapcsolatos büntetendő cselekmények köre és a jogellenes kereskedelem a legkisebb társadalmi figyelmet kapott jelenségek közé tartozik az Európai Unióban, annak ellenre, hogy egyes tagállamoknak súlyos problémákkal kell szembe néznie. A környezeti bűncselekmények és a TOC összefonódása már az Európai Unió részéről is elismerést nyert, az uniós intézmények több döntésben is foglalkoztak a problémával.

Az Európai Unió vadvilági kereskedelemre vonatkozó szabályozásával foglalkozó fejezet több alapvető kérdésre keresi a választ. Elsősorban, egyáltalán milyen jelentőséggel bír a vadvilággal kapcsolatos kereskedelmi tevékenység az Európai Unióban? Továbbá, mikor csatlakozott az EU a CITES-hez és hogyan történt meg a Washingtoni Egyezmény rendelkezéseinek megvalósítása az Európai Unióban és a tagállamok hogyan valósítják meg a CITES-ből és az európai uniós jogból fakadó kötelezettségeiket a vadvilági kereskedelem szabályozása kapcsán? Végül, milyen kormányzó elvek irányítják az Unióhoz kötődő kereskedelmi tevékenységet?

Az Európai Unióhoz kapcsolódó intézményi-szervezti kérdések, amelyek a CITES végrehajtásából adódnak, az értekezés korábbi fejezetében kerültek feltárásra.

\footnotetext{
${ }^{496}$ ENRTP: Environment and Natural Resources Thematic Programme: 2007. és 2013. között.

${ }^{497}$ A Bizottság közleménye az Európai Parlamentnek, a Tanácsnak, a Gazdasági és Szociális Bizottságnak és a Régiók Bizottságának. Életbiztositásunk, természeti tőkénk: a biológiai sokféleséggel kapcsolatos, 2020-ig teljesitendö uniós stratégia 2011. 05. 03. COM/2011/0244 végleges. CELEX-szám: 52011DC0244. [Továbbiakban: A biológiai sokféleséggel kapcsolatos uniós stratégia].

${ }^{498}$ A Bizottság közleménye - A Biológiai sokféleség csökkenésének megállítása 2010-ig - és azon túl - Az ökoszisztéma-szolgáltatások fenntartása az emberi jólét érdekében 2006. 05. 22. COM/2006/0216 végleges. CELEX-szám: 52006DC0216.

${ }^{499}$ A biológiai sokféleséggel kapcsolatos uniós stratégia, 4.1. 9. p.
} 


\section{V.1. A vadvilági kereskedelem jelentősége az Európai Unióban}

Az Európai Unió az egyik legnagyobb és változatosabb piac a világon az élő egyedek, a vadvilági termékek és származékok tekintetében. Az európai integrációhoz csatlakozó tagállamok száma dinamikusan növekedett az elmúlt évtizedekben, ezzel párhuzamosan a vadvilági termékek piaca is változott az Európai Unióban. A 28 tagállam több vadvilági árucikk esetében a legnagyobb globális importőrnek számít, beleértve a hüllő bőröket, az elő hüllőket, a kaviárt, az élő papagájokat és a trópusi fákat is. 2005-ben a vadvilági kereskedelem értéke 93 milliárd EUR volt az EU piacán. Az európai államok mind a CITES listán szereplő, mind pedig az Egyezmény által nem védett fajok tekintetében elsődleges kereskedelmi célpontnak tekinthetők. ${ }^{500}$

Kiemelendő, hogy az Európai Unióban is élesen el kell különíteni egymástól az illegális és jogszerủen folytatott vadvilági kereskedelmet. A nemzetközi szabályozásnál tett megállapítás, hogy a szabályozás a korlátok közé szorított, ellenőrzött, de engedélyezett kereskedelem felé mutat a legveszélyeztetettebb fajok kiemelt védelmével, az Európai Unióban is igaz. Az egységes EU-s szabályozás ellenére számos olyan terület merül fel, amely megnehezíti az illegális kereskedelem elleni küzdelmet. Az első ilyen probléma, hogy a közvélemény csak igen kis százaléka tud és foglalkozik a vadvilági kereskedelemmel, pedig egy-egy távoli országban töltött nyaralás során vásárolt szuvenír kapcsán számos uniós polgár kerülhet kellemetlen helyzetbe a reptéri vizsgálaton. Azonban hozzátehetjük, hogy éppen utóbbi esetek maradnak rejtve legtöbbször a hatóságok elöl.

Ráadásul az évi néhány ezer feltárt eset, mikor illegális kereskedelemi tevékenységet sikerül leleplezni, csak a jéghegy csúcsa, az összes eset mintegy 10-15 százaléka. Az Európai Unió területén egyes őshonos fajok képzik az illegális kereskedelem tárgyát, így a különösen veszélyeztetett európai angolna, amelyet Kínába, Japánba és más ázsiai országokba csempésznek. A jogellenes vadvilági kereskedelem mértékéről az európai színtéren is betekintést biztosít a vámhatóságok és egyéb rendészeti szervek által elkobzott szállítmányok értéke és száma. Az olyan belépési pontok, mint az Egyesült Királyság kikötői és repterei, valamint az ott elkobzott szállítmányok ugyancsak információt biztosítanak a vadvilági kereskedelmi útvonalakról. Az Egyesült Királyság egyik frekventált belépési pontja a Heathrow reptér, amelyet a Manchester és a Gatwick repterek követnek. A

${ }^{500}$ MAYLYNN ENGLER - ROB PARRY-JONES: Opportunity or threat? The role of the European Union in global wildlife trade. Traffic Europe Report 2007., Brüsszel 11. p. 
szállítmányok átvizsgálására és az mérésére a vámhatóságok által csak olyan esetekben kerülhet sor, ahol van határellenőrzés. A határok átjárhatósága az Európai Unióban azt eredményezi, hogy ha egyszer az illegális kereskedelem tárgya bejutott a belső piac területére - olyan belépéséi pontokon keresztül, mint például az Egyesült Királyság - akadályok nélkül áramlik a tagállamok között. Mivel a belső piac a termékek, személyek, szolgáltatások és tőke szabad áramlásán alapszik, a határellenőrzésre vonatkozó közös alapelvek kialakítása nélkülözhetetlen volt. 1996 és 2000 között összesen 2211 elkobzás történt az Egyesült Királyság kikötöiben, amikor CITES listán vagy a WTR mellékletben szereplő fajok illegális szállítása valósult meg. 1999 és 2000 között ezen elkobzott szállítmányok 17 százaléka volt élő egyed, amely csaknem fele hüllő volt. Az összes szállítmány csaknem 75 százaléka a tradicionális ázsiai gyógyászathoz szükséges termékek voltak. Mindazonáltal érdekes a beérkező elefántcsont alacsony aránya, mindösszesen 36 kisebb szállítmányt derítettek fel, amelyből a nyers elefántcsont afrikai országokból, a megmunkált elefántcsont pedig Indonéziából az Amerikai Egyesült Államokból és egyéb országokból származott. ${ }^{501}$ Véleményem szerint az elefántcsont alacsony aránya magyarázható azzal, hogy a 2000-es évek elejére némileg csökkent az illegális kereskedelem, azonban a későbbi mutatószámokból látható majd, hogy alig néhány évvel később az Afrikában új erőre kapott orvvadászat miként hatott az elefántcsont behozatalára.

Az elkobzára vonatkozó legújabb adatok alapján a nemzetközi elkobzás ${ }^{502}$ mintegy 97 százalékát Ausztria, az Egyesült Királyság, Németország, Spanyolország és Dánia jelentette be 2015-ben. A mintegy két évtizeddel korábbi adatokhoz képest jelentősen elöre lépett az elkobzott elefántcsont aránya. A szállítmányok között az első helyet továbbra is a gyógyászati célra használt termékek foglalják el (csaknem 900 ezer növény-származékot tartalmazó tétel és megközelítően 25 ezer állati származék, együttesen 1500 kg súlyban), amelyet több mint fél tonna elefántcsont követ. Ugyancsak magas számban szerepelnek az emlősök, madarak és hüllők (élő egyedek, tetemek, részek és származékok), a korallok, a kaviár és az élő növények. A származási országokat tekintve az Amerikai Egysült Államokból elsősorban a medicina termékei érkeznek. Az Egyesült Királyság 158 esetben jelentett tételenként csekély mennyiségű elefántcsontot tartalmazó szállítmányokat, amelyek nagy részét interneten adták el, Kínából, de maga az elefántcsont afrikai

${ }^{501}$ Switching Channels. Wildlife trade routes into Europe and the UK. A WWF/TRAFFIC Report. 2002 decembere. 12-13. p. [Továbbiakban: Switching Channels].

502 A határoknál történő vizsgálat során felfedezett illegális szállítmányok elkobzása. Például harmadik államokból érkező szállítmányok, amelyet az EU külső határainál ellenőriznek. 
volt. Kínából közvetlenül elsősorban a tradicionális ázsiai medicina termékei érkeznek. Thaiföldről az élő korallok és orchideák, valamint egyéb növények származnak. ${ }^{503}$ Azonban az Európai Unió nem csak cél, hanem tranzitállomás is a vadvilági kereskedelem útvonalain. Ez azt jelenti, hogy földrajzi elhelyezkedésénél fogva az Afrikából, és az USA-ból Európába érkező tételeket nem itt vásárolják meg, hanem azokat tovább küldik Ázsia felé. A harmadik államokkal, az Európai Unióból folytatott export és re-export célállomásai között élen szerepel Kína, amelyet Hong Kong és Thaiföld követ. Utóbbi országokba az elsősorban afrikai elefántcsontot szállítják, de a rinocéroszszarv ugyancsak kedvelt terméknek számít. Az elefántcsontkereskedelem további célállomása Vietnám, ahova a nyers és megmunkált afrikai elefántcsont érkezik. Többek között Franciaországban fedeztek fel elefántagyar darabokat egy vietnámi állampolgár táskájában, amely Angolából származott. A nyers elefántcsont származási helyei leggyakrabban Nigéria, Guinea, Egyenlítői-Guinea és Mali, míg a megmunkált faragványok Nigériából, Elefántcsontpartból és a Kongói Demokratikus Köztársaságból származnak. További fontos kereskedelmi cikknek tekinthetök a szárított csikóhalak és a tobzoska pikkelyek, amelyeket szintén a hagyományos gyógyászatban használnak fel. ${ }^{504}$ Az Európai Unió tehát kiemelt tranzitállomás a kontinensek közötti kereskedelemben. Szlovákia, Csehország, Németország és Belgium pedig az Afrikából, más kontinensekre történő illegális elefántcsontkereskedelem legfontosabb tranzitállamai. Írország és Csehország pedig Kína és Vietnám mellett a legfontosabb felvevőpiacok az illegális elefántcsont tekintetében. Ráadásul, ha egy termék vagy élö példány egyszer átjut a vámellenörzésen, az egész EU területén szabadon mozog és nagy valószínűséggel sohasem kerül a hatóságok látóterébe. ${ }^{505}$ 1997. és 1999. között a nyugat-európai államok csaknem 23 ezer CITES engedélyezés alatt álló szállítmányt importáltak az Európai Unió területére és csaknem 16 ezer ilyen szállítmányt engedélyeztek kivitelre. ${ }^{506}$ A vadvilági kereskedelem éves szinten 8 és 20 milliárd EUR közötti üzlet. Nem meglepő, hogy az utóbbi néhány évben új erőre kapott az illegális tevékenységeknek ez az oly jövedelmező formája. ${ }^{507}$ Az Európai Unió az egyik legfontosabb felvevőpiaca a vadvilági termékeknek, azonban egyes tagállamoknak

\footnotetext{
${ }^{503}$ Briefing prepared by TRAFFIC for the European Commission. Overview of imortant international seizures in the European Union. January to December 2015 Compiled by TRAFFIC (April 2016, updated in March 2017) 1-3. p. [Továbbiakban: Seizures, 2015.].

${ }^{504}$ Seizures, 2015. 4 p.

${ }^{505}$ Europe, a silent hub of illegal wildlife trade.

${ }^{506}$ Switching Channels, 8 p.

${ }^{507}$ The scale of wildlife trafficking.

http://ec.europa.eu/environment/cites/pdf/infographics/infographic-wildlife-scale.pdf (2019. 02. 23.).
} 
problémákkal kell szembe néznie a CITES végrehajtása során. A tranzitállamok kiemelten nehéz helyzetben vannak, hiszen a vám- és egyéb rendészeti szervekre nagy terhet ró a jogellenes kereskedelem felderítése és a CITES szabályok kikényszerítése.

A tagállamok dinamikusan növekvő száma, valamint a közép- és kelet európai országok csatlakozása további nehézségeket és kihívásokat tartogatott az Európai Unió számára. Az Európai Unió tagszámának 15-ről 25-re, majd 2007-ben 27-re és végül 2013-ban 28ra növekedésével kétségtelenül megnőtt a belső piac nagysága. A később csatlakozó államok közül, a Közép- és Kelet-Európai országok tradicionálisan nagy szereppel bírtak mint tranzitállamok - a vadvilági kereskedelemben, már az Unióhoz való csatlakozást megelőzően is. Továbbá, több országban találunk CITES listára vett és a vadvilági kereskedelem szempontjából jelentős őshonos fajokat, mint a barnamedve (Ursus arctos), ragadozómadár fajokat és a hagyományos medicinában felhasznált növényeket, mint a ciklámen. Mindazonáltal a korábban, vagyis 2004 előtt is tag 15 államhoz képest az újonnan csatlakozó országok kevésbé jelentősek a CITES-fajok importját tekintve. ${ }^{508}$ Utóbbi oka, hogy az érintett Közép- és Kelet-Európai államok - földrajzi elhelyezkedésüknél fogva is - kiváló tranzitállomások, azonban a kereslet kisebb a veszélyeztetett fajokra. Bár az őshonos fajok egy részét tekintve, fontos piacot jelentenek a védett és ritka állat- és növényfajokat nézve.

A csatlakozást megelőzően már 2002-ben is készült egy jelentés ${ }^{509}$, amely az új tagállamok csatlakozásának hatását vizsgálta az Európai Unió vadvilági kereskedelemre vonatkozó szabályozását illetően. A 2002-es jelentés is felhívta a figyelmet arra, hogy a keleti kibővítéssel a belsö piac határai jelentősen kitolódnak, ahol szigorú határellenőrzésre és megfelelő szaktudást, valamint erőforrásokat felvonultató vizsgálószerveknek kell rendelkezésre állnia.

Megállapítható, hogy 2004-re, mikor az új EU10 csatlakozott az integrációhoz, már megvalósították azokat a változtatásokat, elsősorban jogszabályalkotással, amelyek lehetővé tették az Európai Unió vadvilági kereskedelemre vonatkozó rendeleteinek végrehajtását. Ugyanakkor egyes államokban, mint Litvániában fontos szabályozási elemek végrehajtása csúszott, a jogszabályalkotás ütemére való tekintettel. Továbbá, néhol az uniósnál

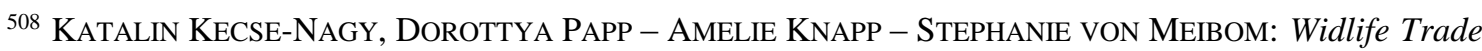
in Central and Eastern Europe. A review of CITES implementation in 15 countries. TRAFFIC Europe report, Budapest, Hungary, 2006. 8. p.

[Továbbiakban: Widlife Trade in Central and Eastern Europe, 2006.].

${ }^{509}$ BERKHOUDT, KARIN: Focus on EU Enlargement és Wildilfe Trade: Review of CITES implementation in Candidate Countries. TRAFFIC Europe, 2002.
} 
szigorúbb szabályozás volt életben - már a csatlakozást megelözően is - a CITES végrehajtása érdekében. Példaként felhozható Magyarország is, ahol többek között a CITES listán szereplő fajok regisztrációja kapcsán szigorúbb előírások voltak, mint amit a rendeletek megköveteltek. Így voltaképpen több esetben is, a szabályozás módosítása a védelmi szint csökkenését jelentette volna. A legnagyobb kihívás az információáramlás biztosítása volt, amely érdekében az újonnan csatlakozó államoknak ki kellett építeni a szükséges rendszereket, hogy az adatbázisokhoz való hozzáférhetőség, valamint a gyors és egyszerű információlekérés megvalósulhasson. További lépéseket kellett tenni a kifejezetten környezettel kapcsolatos büncselekmények felderítése érdekében, így sok esetben külön egységek kerültek létrehozásra a rendőrségen belül (pl. 2005-ben Magyarországon jött létre a környezeti büncselekményekkel foglalkozó egység). ${ }^{510}$ Azonban a legnagyobb kihívás a jogellenes cselekmények leleplezése. Hiszen, ha a határokon nem derítik fel az Európai Unióba jogellenesen érkező szállítmányokat, hiába a büntetőjogi szabályozás, ha maga a tett rejtetten marad. Ennek érdekében több állam figyelmét is felhívták a megfelelő szakértelemmel rendelkező vámtisztek kiképzésére, akik képesek felismerni a vadvilági termékeket, egyedeket és az illegális tevékenységre utaló jeleket. Újra hangsúlyozni kell, ha egy termék vagy egyed bejut a belső piacra, 28 állam között szabadon mozog és a lelepleződés esélye igen csekéllyé válik. Ezért feltétlenül szükséges, hogy az utolsó ,,védelmi vonalat” biztosító tagállamok megfelelő figyelmet tanúsítsanak az egyre fenyegetőbb, vadvilágot károsító büncselekményeknek.

Összegezve elmondható, hogy a vadvilági kereskedelem jelentős szektort jelent az Európai Unióban és a tagállamok gazdasági tevékenységében. Azonban a nagy arányú jogszerü tevékenység mellett egyre inkább teret nyert az illegális vadvilági kereskedelem és a vadvilággal kapcsolatos bűncselekmények. A jelenség elhatalmasodása több tényező eredménye, kezdve az EU belső piacának bővülésével, az újonnan csatlakozó tagállamok miatt, valamint a volt szovjet térségben tevékenykedő szervezett bűnözői csoportok terjeszkedésének. Az Európai Unió 2004-es kibővülése jelentős változásokat hozott a belső piacon és az EU külső határellenőrzésében is. Azonban az Európai Unió széles körü normaalkotással és a nemzetközi szerződéshez való csatlakozással igyekszik felvenni a versenyt a TOC ellen és gátat szabni a veszélyeztetett fajok kihalásának, a biodiverzitás csökkenésének. Mivel számos, az európai kontinensen honos faj is ki van téve az illegális

\footnotetext{
${ }^{510}$ Widlife Trade in Central and Eastern Europe, 2006. 100-102. p.
} 
begyüjtésnek, vadászatnak a téma különös jelentőséggel bír a biológiai sokféleség megőrzése érdekében is.

\section{V.2. Az Európai Unió csatlakozása a Washingtoni Egyezményhez}

Az Európai Unió csatlakozása a CITES Egyezményhez egy több lépcsős folyamat eredménye volt. Az európai integráció tekintetében az Európai Unió létrehozása ${ }^{511}$ és a Liszszaboni Szerződés ${ }^{512}$ által nyert jogi személyiség volt az a két fordulópont, amely nagyban hozzájárult az Egyezményben való részes féllé váláshoz. A EU a Lisszaboni Szerződés hatálybalépésével jogi személyiséget szerzett, ezáltal a nemzetközi jog alanyává vált. A jogalanyiság pedig lehetővé teszi, hogy saját nevében tárgyalhasson és köthessen nemzetközi megállapodásokat, azaz ezen a téren a szerződések által ráruházott hatáskörökkel rendelkezik. ${ }^{513}$ Azonban a Washingtoni Egyezmény tekintetében is változásoknak kellett történni ahhoz, hogy az EU csatlakozhasson a CITES-hez, amelyre végül 2015. július 8án került sor.

Az Egyezményhez való csatlakozás lehetőségét még a CITES gaborone-i módosítása alapozta meg. A gaborone-i módosítás, amelyet a részes felek konferenciája 1983-ban fogadott el Botswanaiban, úgy módosította az Egyezmény XXI. cikkét, hogy az Egyezményhez való csatlakozás - amely addig csak államok számára volt lehetséges - nyitva álljon az olyan, szuverén államok által alkotott regionális gazdasági integrációs szervezetek számára is, amelyek a tagállamaik által a hatáskörükbe utalt és az Egyezmény által szabályozott ügyekben jogosultak nemzetközi megállapodások tárgyalására, megkötésére és végrehajtására. ${ }^{514}$ Azonban a szükséges ratifikációk számára tekintettel a módosítás csak 2013. november 29-én lépett hatályba. Ezután az Európai Unió minden, az Egyezményhez való csatlakozáshoz szükséges jogi lépést a lehető leghamarabb végrehajtott. Az Európai Parlament 2014 decemberében adta beleegyezését a csatlakozáshoz, amelyet

\footnotetext{
${ }^{511}$ Az Európai Uniót a Maastrichti Szerződés hozta létre. Az Európai Unióóól szóló Maastrichti szerződés (1992. február 07.; 1993. november 01.). (OJ C 191, 29.7.1992, p. 1-112) CELEX 11992M/TXT.

${ }^{512}$ Lisszaboni Szerződés az Európai Unióról szóló szerzödés és az Európai Közösséget létrehozó szerződés módosításáról, amelyet Lisszabonban, 2007. december 13-án írtak alá. (2007. december 13.; 2009. december 1.) (OJ C 306, 17.12.2007, 1-271. p.) CELEX 12007L/TXT.

${ }^{513}$ Nemzetközi megállapodások és az EU külügyi hatáskörei http://eur-lex.europa.eu/legal-content/HU/TXT/?uri=LEGISSUM:ai0034 (2019. 02. 23.).

${ }^{514}$ A Tanács (EU) 2015/451 határozata (2015. március 6.) az Európai Uniónak a veszélyeztetett vadon élő állat- és növényfajok nemzetközi kereskedelméről szóló egyezményhez (CITES) való csatlakozásáról (HL L 75., 2015.3.19., 1-3. p.) [Továbbiakban: Tanács (EU) 2015/451 határozata].
} 
Tanács ${ }^{515}$ 2015. március 6-án hagyott jóvá. ${ }^{516}$ Az Európai Unió tagálalmain végig tekintve, azok már a CITES részes feleivé váltak, majd az EU is csatlakozott az Egyezményhez. Az EU tagállamok abban a speciális helyzetben vannak, hogy egyrészről teljesíteniük kell a CITES-hez való csatlakozás által vállalt nemzetközi kötelezettségeiket, másrészt végre kell hajtaniuk az uniós tagságból fakadó, a fajok kereskedelmére vonatkozó jogi szabályozást. Ehhez még hozzájárul a tagállamok belső, vadvilági kereskedelemre és illegális tevékenységekre vonatkozó szabályozása, amelynek összhangban kell lennie mind a nemzetközi, mind az uniós joggal. Így elmondhatjuk, hogy az EU tagállamok, így Magyarország tekintetében is a veszélyeztetett fajok kereskedelmére vonatkozó szabályozásnak három rétege van, amelyek egymásra épülnek és kiegészítik egymást. Ma már minden uniós tagállam részes fél a Washingtoni Egyezményben.

„Az EU büszke arra, hogy világszinten élen jár a vadon élő állat- és növényfajok jogellenes kereskedelme ellen vívott küzdelemben. Véleményünk szerint a konferencia* lehetöséget kínál arra, hogy még keményebben lépjünk fel a vadon élö állat- és növényfajok tiltott kereskedelme és az ehhez táptalajként szolgáló korrupció ellen. A CITES keretében partnereinkkel közösen azon fogunk dolgozni, hogy maradéktalanul végrehajtsuk a vadvilág védelmét szolgáló új uniós cselekvési tervet. Globális szövetséget épitünk abból a célból, hogy az élöhelyükön megóvjuk az állatokat és növényeket, az átkelöhelyeken elzárjuk a csempészek útját, és teljesen felszámoljuk a tiltott kereskedelem iránti keresletet." ${ }^{\prime 517}$

[*Johannesburg, 2016.]

Az Európai Unió 2016. szeptemberében, Johannesburgban vett részt először teljes jogú részes félként a CITES részes feleinek konferenciáján. Az Európai Unió elhivatottan szorgalmazta szigorúbb nemzetközi intézkedések meghozatalát a vadon élő állat- és növényfajok jogellenes kereskedelme ellen, kifejezetten összhangban a témában kidolgozott uniós cselekvési tervvel. A CoP-n képviselt álláspontot a tagállamok és az EU együtt alakítja ki. Az Unió képviseltében Karmenu Vella, a környezetpolitikáért, a tengerügyekért és a halászatipolitikáért felelős biztos vett részt az EU képviseletében. ${ }^{518}$

\footnotetext{
515 Tanács (EU) 2015/451 határozata (2) bekezdés.

${ }^{516}$ EU Accession to CITES http://ec.europa.eu/environment/cites/gaborone_en.htm (2018.09.24.).

${ }^{517}$ Karmenu Vella, uniós biztos. Az EU a globális csúcstalálkozón a vadon élö állat- és növényfajok kereskedelmére vonatkozó szabályok további szigoritását szorgalmazza. Sajtóközlemény, Brüsszel, 2016. szeptember 23. [Továbbiakban: Sajtóközlemény]

Idézet forrása: https://europa.eu/rapid/press-release_IP-16-3144_hu.htm (2019. 08. 10.).

${ }^{518}$ Sajtóközlemény.
} 
3. táblázat Az uniós tagállamok csatlakozása a CITES-hez ${ }^{519}$

\begin{tabular}{|l|c|c|c|}
\hline & $\begin{array}{c}\text { Csatlakozás az } \\
\text { európai integ- } \\
\text { rációs szerve- } \\
\text { zetekhez }\end{array}$ & $\begin{array}{c}\text { Csatlakozás a Washingtoni } \\
\text { Egyezményhez }\end{array}$ \\
\cline { 3 - 4 } & $\begin{array}{c}\text { Csatlakozás } \\
\text { dátuma }\end{array}$ & $\begin{array}{c}\text { Hatálybelé- } \\
\text { pés dátuma }\end{array}$ \\
\hline Ausztria & $1995 / 01 / 01$ & $1982 / 01 / 27$ & $1982 / 04 / 27$ \\
\hline Belgium & $1958 / 01 / 01$ & $1983 / 10 / 03$ & $1984 / 01 / 01$ \\
\hline Bulgária & $2007 / 01 / 01$ & $1991 / 01 / 16$ & $1991 / 04 / 16$ \\
\hline Ciprus & $2004 / 05 / 01$ & $1974 / 10 / 18$ & $1975 / 07 / 01$ \\
\hline Csehország & $2004 / 05 / 01$ & $1993 / 01 / 01$ & $1993 / 04 / 14$ \\
\hline Dánia & $1973 / 01 / 01$ & $1977 / 07 / 26$ & $1977 / 10 / 24$ \\
\hline $\begin{array}{l}\text { Egyesült } \text { Kírály- } \\
\text { ság }\end{array}$ & $1973 / 01 / 01$ & $1976 / 08 / 02$ & $1976 / 10 / 31$ \\
\hline Észtország & $2004 / 05 / 01$ & $1992 / 07 / 22$ & $1992 / 10 / 20$ \\
\hline Finnország & $1995 / 01 / 01$ & $1976 / 05 / 10$ & $1976 / 08 / 08$ \\
\hline Franciaország & $1958 / 01 / 01$ & $1978 / 05 / 11$ & $1978 / 08 / 09$ \\
\hline Görögország & $1981 / 01 / 01$ & $1992 / 10 / 08$ & $1993 / 01 / 06$ \\
\hline Hollandia & $1958 / 01 / 01$ & $1984 / 04 / 19$ & $1984 / 07 / 18$ \\
\hline Horvátország & $2013 / 07 / 01$ & $2000 / 03 / 14$ & $2000 / 06 / 12$ \\
\hline Írország & $1973 / 01 / 01$ & $2002 / 01 / 08$ & $2002 / 03 / 08$ \\
\hline Lengyelország & $2004 / 05 / 01$ & $1989 / 12 / 12$ & $1990 / 03 / 12$ \\
\hline Lettország & $2004 / 05 / 01$ & $1997 / 02 / 11$ & $1997 / 05 / 12$ \\
\hline Litvánia & $2004 / 05 / 01$ & $2001 / 12 / 10$ & $2002 / 03 / 09$ \\
\hline Luxemburg & $1958 / 01 / 01$ & $1983 / 12 / 13$ & $1984 / 03 / 12$ \\
\hline Magyarország & $2004 / 05 / 01$ & $1985 / 05 / 29$ & $1985 / 08 / 22$ \\
\hline Málta & $2004 / 05 / 01$ & $1989 / 04 / 17$ & $1989 / 07 / 16$ \\
\hline Németország & $1958 / 01 / 01$ & $1976 / 03 / 22$ & $1976 / 06 / 20$ \\
\hline Olaszország & $1958 / 01 / 01$ & $1979 / 10 / 02$ & $1979 / 12 / 31$ \\
\hline Portugália & $1986 / 01 / 01$ & $1980 / 12 / 11$ & $1981 / 03 / 11$ \\
\hline Románia & $2007 / 01 / 01$ & $1994 / 08 / 18$ & $1994 / 11 / 16$ \\
\hline Spanyolország & $1986 / 01 / 01$ & $1986 / 05 / 30$ & $1986 / 08 / 28$ \\
\hline Svédország & $1995 / 01 / 01$ & $1974 / 08 / 20$ & $1975 / 07 / 01$ \\
\hline Szlovákia & $2004 / 05 / 01$ & $1993 / 01 / 01$ & $1993 / 03 / 02$ \\
\hline Szlovénia & $2004 / 05 / 01$ & $2000 / 01 / 24$ & $2000 / 04 / 23$ \\
\hline & & \multicolumn{2}{|c|}{} \\
\hline
\end{tabular}

519 3. táblázat a szerző saját fordítása, szerkesztése. A csatlakozási dátumok forrása: List of Contracting Parties. https://www.cites.org/eng/disc/parties/chronolo.php (2019. 07. 21.). 


\section{V.3. Az Európai Unió vadvilági kereskedelemre vonatkozó normái}

\section{V.3.1. A szabályozás kezdeti lépései és módosításai}

Bár hivatalosan csak 2015-ben lett részes fél az Európai Unió, veszélyeztetett fajok kereskedelmére vonatkozó szabályozás szigorúsága tekintetében az Európai Unió, illetve korábban a Közösség már 1984-re megvalósította és néhány tekintetben túl is szárnyalta a CITES által felállított követelményeket. Így voltaképpen már a gaborone-i módosítás elfogadását követő évben megvalósításra kerültek az Egyezmény szabályai. A 3626/82/EGK Rendelet szólt a veszélyeztetett állat- és növényfajok nemzetközi kereskedelméről szóló egyezmény Közösségben való végrehajtásáról. A rendelet 1984-ben lépett hatályba. A rendelet kiemeli, hogy a Közösség tagállamai már 1977-ben ${ }^{520}$ állást foglaltak a vadon élö állat- és növényfajok védelmének szükségessége mellett, amely mind a mai napig egyik alapja az Európai Unió környezetpolitikájának. Mindamellett kiemelik, hogy a CITES főként kereskedelem-politikai eszközöket alkalmaz, így az engedélyek és a szigorú nemzetközi kereskedelmi kontroll módszereit. Már ebben a rendeletben lefektették azt az alapelvet, hogy az Egyezmény szabályainak végrehajtása semmiképpen sem akadályozhatja a tagállamok közötti közös piacon történő kereskedelmet, de mindenképpen alkalmazásra kerülnek a harmadik államokkal folytatott ügyletekben. ${ }^{521}$ A CITES Közösségen belüli végrehajtásának másik eleme a 3418/83/EGK bizottsági rendelet ${ }^{522}$ volt, amely a CITES Közösségen belüli végrehajtásához szükséges dokumentációról és a terminológiáról szólt. 1982-ben az akkori 10 tagállamból csupán öt volt részes fél az Egyezményben. A két rendelet 1984. január 1-jén lépett hatályba és minden tagállamban alkalmazni kellett akkor is, ha azok még nem csatlakoztak a CITES-hez.

1991 decemberében a Bizottság javasolta a Tanácsnak, hogy az 1982-es rendeletet helyettesítsék egy átfogóbb szabályozással, 1993. január 1-jével, vagyis a belső piac létrejöttének dátumától. A módosítást indokolta, hogy a belső határellenőrzés szinte teljes eltünése és a termékek, szolgáltatások, munkaerő és tőke szabad áramlása szükségessé tette

\footnotetext{
${ }^{520}$ Resolution of the Council of the European Communities and of the representatives of the Governments of the Member States meeting within the Council of 17 May 1977 on the continuation and implementation of a European Community policy and action programme on the environment. 1977. május 17-i Tanácsi találkozó (HL C 139., 1977.6.13., 1-46. p.) CELEX-szám: 41977X0613.

${ }^{521}$ A Tanács 3626/82/EGK rendelete (1982. december 03) a CITES Közösségen belüli végrehajtásáról (HL L 384., 1982.12.31., 1-61. p.) CELEX-szám: 31982R3626 Érvényesség vége: 1996. 12. 31.

${ }^{522}$ A Bizottság 3418/83/EGK rendelete a CITES Közösségen belüli végrehajtásához szükséges dokumentumok kérdéséről (1983. november 28.) (HL L 344., 1983.12.7., 1-27. o.) CELEX-szám: 31983 R3418 Érvényesség vége: 1997.05 .31$.
} 
a korábbi rendelet felülvizsgálatát. Továbbá, az 1982-es rendeletet a tagállamok eltérően hajtották végre, amely a részes felek konferenciájának ajánlásaival együtt zürzavarhoz és a harmonizáció hiányához vezetett. Végül az 1980-as évek elején elfogadott szabályozást a vadvilági kereskedelemkontroll technikáinak és politikájának fejlődése miatt is felül kellett vizsgálni.

A Tanácsnak végül az eredeti terveknél jóval tovább tartott az új rendelet elfogadása. 1996. december 9-én fogadták el a 338/97/EK tanácsi rendeletet a vadon élö állat- és növényfajok számára kereskedelmük szabályozása által biztosított védelemröl és a következő évben a Bizottság elfogadta a 939/97/EK rendeletet ${ }^{523}$ a vadon élő állat- és növényfajok számára kereskedelmük szabályozása által biztosított védelemről szóló 338/97/EK tanácsi rendelet végrehajtására vonatkozó részletes szabályok megállapításáról. Az utóbbi rendeletet a Bizottság már két alkalommal is helyettesítette ${ }^{524}$ a részes felek konferenciáin elfogadott új szabályoknak való megfelelés érdekében. ${ }^{525}$ Majd a 791/2012/EU bizottsági rendeletet alkották meg a 338/97/EK tanácsi rendelet végrehajtására vonatkozó részletes szabályok megállapításáról szóló 865/2006/EK rendeletnek a vadon élő állat- és növényfajok kereskedelmére vonatkozó bizonyos rendelkezések tekintetében történő módosításáról. ${ }^{526}$ Ezután a 870/2015/EU bizottsági rendeletet fogadták el, ugyanebben a tárgykörben. ${ }^{527}$ Végül a Bizottság 792/2012/EU végrehajtási rendelete került elfogadásra a vadon élő állat- és növényfajok számára kereskedelmük szabályozása által biztosított védelemről szóló 338/97/EK tanácsi rendeletben elöírt engedélyek, bizonyítványok és más okmányok mintáira vonatkozó szabályok megállapításáról és a

\footnotetext{
${ }^{523}$ A Bizottság 939/97/EK rendelete (1997. május 26.) a veszélyeztetett állat- és növényfajok védelméröl szóló 338/97 tanácsi rendelet részletes végrehajtásáról (HL L 140., 1997.5.30., 9—50. o.) CELEX-szám: 31997R0939 Érvényesség vége: 2001. 09. 21.

${ }^{524}$ Először a Bizottság 1808/2001/EK rendeletével (2001. augusztus 30.) a vadon élő állat- és növényfajok számára kereskedelmük szabályozása által biztosított védelemről szóló 338/97/EK tanácsi rendelet végrehajtására vonatkozó részletes szabályok megállapításáról (HL L 250., 2001.9.19., 1—43. p.) CELEXszám:32001R1808 Érvényesség vége: 2006. 08. 08., majd a jelenleg is hatályos, módosított 865/2006/EK Rendelettel.

${ }^{525}$ Reference Guide, 2017. 144-145. p.

${ }^{526}$ A Bizottság 791/2012/EU rendelete (2012. augusztus 23.) a 338/97/EK tanácsi rendelet végrehajtására vonatkozó részletes szabályok megállapításáról szóló 865/2006/EK rendeletnek a vadon élő állat- és növényfajok kereskedelmére vonatkozó bizonyos rendelkezések tekintetében történő módosításáról (HL L 242., 2012.9.7., 13-45. p.) CELEX-szám: 32012R0791.

${ }^{527}$ A Bizottság 870/2015/EU rendelete (2015. június 5.) a 338/97/EK tanácsi rendelet végrehajtására vonatkozó részletes szabályok megállapításáról szóló 865/2006/EK rendeletnek a vadon élő állat- és növényfajok kereskedelme tekintetében történő módosításáról (HL L 142., 2015.6.6., 3-20. p.) CELEX-szám: 32015R0870.
} 
865/2006/EK bizottsági rendelet módosításáról. ${ }^{528}$ Utóbbi elsősorban az engedélyekre és dokumentumokra vonatkozó rendelkezéseket törölte és helyettesítette.

A legutóbbi jelenleg hatályos jogforrás, a vadon élő állat- és növényfajok számára kereskedelmük szabályozása által biztosított védelemről szóló 338/97/EK tanácsi rendelet végrehajtására vonatkozó részletes szabályok megállapításáról szóló 865/2006/EK rendelet módosításáról 2019. február 6-án került megalkotásra. ${ }^{529}$ Egyrészről az élő orrszarvúakra és élő elefántokra vonatkozó engedélyek és bizonyítványok konkrét tartalmának, másrészt az engedélyekben és bizonyítványokban az érintett példányok leírásaiban alkalmazandó kódok és mértékegység jelölések változtatása történt.

\footnotetext{
${ }^{528}$ A Bizottság 792/2012/EU végrehajtási rendelete (2012. augusztus 23.) a vadon élő állat- és növényfajok számára kereskedelmük szabályozása által biztosított védelemről szóló 338/97/EK tanácsi rendeletben elöírt engedélyek, bizonyítványok és más okmányok mintáira vonatkozó szabályok megállapításáról és a 865/2006/EK bizottsági rendelet módosításáról (HL L 242., 2012.9.7., 13 - 45. p.) CELEX-szám: 32012R0792.

${ }^{529}$ A Bizottság 220/2019/EU rendelete (2019. február 6.) a vadon élő állat- és növényfajok számára kereskedelmük szabályozása által biztosított védelemről szóló 338/97/EK tanácsi rendelet végrehajtására vonatkozó részletes szabályok megállapításáról szóló 865/2006/EK rendelet módosításáról (HL L 35., 2019.2.7., 3-27. p.) CELEX-szám: 32019R0220.
} 


\section{V.3.2. Wildlife Trade Regulations, az Európai Unió vadvilági kereske- delemre vonatkozó rendeletei és döntései}

Természetesen az 1982-ben elfogadott Rendelet számos módosításon esett át és mára az Európai Unió veszélyeztetett fajok kereskedelmére vonatkozó szabályozásának kiterjedt jogszabályi háttere van, amely így jelentős hatást gyakorol a tagállamokra. A CITES szabályai voltaképpen rendeletek és egyéb jogi normák során keresztül kerülnek végrehajtásra az Európai Unióban. Az Unióban nélkülözhetetlen a kereskedelemre vonatkozó egységes szabályozás, hiszen a tagállamok közötti szisztematikus és állandó határellenőrzés hiánya miatt az áruk, így a belső piac területére behozott vadvilági termékek is szabadon mozoghatnak. Az elöbbiekre tekintettel különösen fontos, hogy az egyes tagállamokban az Egyezmény szabályai egységesen kerüljenek végrehajtásra és megvalósításra. ${ }^{530}$ Mivel az Európai Unióban a jogegységesítés elsődlegesen rendeleti szabályozáson keresztül valósul meg, a vizsgált területen is ez a jellemző.

A veszélyeztetett fajok kereskedelmére vonatkozó jogi normák az Európai Unióban:531

- a Tanács 338/97/EK rendelete (1996. december 9.) a vadon élő állat- és növényfajok számára kereskedelmük szabályozása által biztosított védelemröl (Alap Rendelet); ${ }^{532}$

- a Bizottság 865/2006/EK rendelete (2006. május 4.) a vadon élő állat- és növényfajok számára kereskedelmük szabályozása által biztosított védelemről szóló 338/97/EK

\footnotetext{
530 The European Union and Trade in Wild Fauna and Flora. Introduction. http://ec.europa.eu/environment/cites/legislation_en.htm (2019.03.03.).

${ }^{531}$ Az egyes jogforrásokhoz kapcsolódó magyar nyelvű elnevezések az angol nyelvü, az Európai Unió által is széles körben használt megfelelőjükből erednek. Így ennek megfelelően: „Basic Regulation”, vagyis Alap Rendelet; „Implementing Regulation”, amely leginkább Végrehajtási Rendeletnek fordítható; „Permit Regulation”, amely az Engedélyezési Rendelet; és a „Suspension Regulation” vagyis Tilalmi Rendelet. Az értekezés további hivatkozásiban a meghatározott előbbi elnevezések kerülnek alkalmazásra.

${ }^{532}$ HL L 61., 1997.3.3., 1—69. p. CELEX-szám: 31997R0338

Az Alap Rendeletet számos alkalommal módosították már. (Részletesen: https://eur-lex.europa.eu/legalcontent/HU/ALL/?uri=CELEX:31997R0338\&qid=1566983804981)

A 2017. évi részes felek konferenciájára tekintettel az alapdokumentumot módosította a Bizottság (EU) 2017/128 rendelete (2017. január 20.) a vadon élő állat- és növényfajok számára kereskedelmük szabályozása által biztosított védelemről szóló 338/97/EK tanácsi rendelet módosításáról. (HL L 21., 2017.1.26., 1-98. p.) CELEX-szám: 32017R0128 Érvényesség vége: 2017. 01. 26.

Azonban a 2017/128-as rendeletet később megsemmisítették. Helyesbítés a vadon élö állat- és növényfajok számára kereskedelmük szabályozása által biztosított védelemről szóló 338/97/EK tanácsi rendelet módosításáról szóló, 2017. január 20-i (EU) 2017/18 bizottsági rendelethez (HL L 21., 2017.1.26.) (HL L 23., 2017.1.28., 123-123. p.) CELEX-szám: 32017R0128R(01).

Az utolsó, jelenleg is hatályos módosítás: A Bizottság (EU) 2017/160 rendelete (2017. január 20.) a vadon élő állat- és növényfajok számára kereskedelmük szabályozása által biztosított védelemről szóló 338/97/EK tanácsi rendelet módosításáról. (HL L 27., 2017.2.1., 1-98. p.) CLEX-szám: 32017R0160. (A jelentéstételi kötelezettségre vonatkozó módosítások 2020. 01. 01. lépnek majd hatályba.).
} 
tanácsi rendelet végrehajtására vonatkozó részletes szabályok megállapításáról (Végrehajtási Rendelet) ${ }^{533}$ [az előző fejezetben ismertetett módosításokkal]

- a Bizottság 792/2012/EU végrehajtási rendelete (2012. augusztus 23.) a vadon élő állat- és növényfajok számára kereskedelmük szabályozása által biztosított védelemről szóló 338/97/EK tanácsi rendeletben elöírt engedélyek, bizonyítványok és más okmányok mintáira vonatkozó szabályok megállapításáról és a 865/2006/EK bizottsági rendelet módosításáról (Engedélyezési Rendelet); ${ }^{534}$ [amely nagyban módosította a Végrehajtási Rendeletet]

- tilalmi rendeletek, amelyek közül a legutóbbi a Bizottság (EU) 2017/1915 végrehajtási rendelete (2017. október 19.) ${ }^{535}$ egyes vadon élő állat- és növényfajok példányainak az Unióba történő behozatalának tilalmáról.

Az Európai Unió veszélyeztetett fajok kereskedelmére vonatkozó szabályozása több rétegre tagolható. Az alapvető célkitűzéseket tartalmazza az Unió vadvilági kereskedelmi politikája, amely az elfogadott cselekvési tervekben mutatkozik meg. A cselekvési terv a vadon élő állatok és növények jogellenes kereskedelme ellen - a Bizottság 2016. évi egyik közleményében található meg. ${ }^{536}$ Ezt követi a tételes jogi szabályozás, amely elsősorban rendeleti, így kötelező és közvetlen hatályú jogforrási szinten került megállapításra. A három fő rendelet, az Alap Rendelet, a Végrehajtási Rendelet és az Engedélyezési Rendelet alapvető szabályozást fektet le. Ezt a rendszert egészítik ki a tilalmi rendeletek, amelyek egyes vadon élő állat- és növényfajok példányainak az Unióba történő behozatali tilalmáról, vagyis a belső piacon történő megjelenésnek a megakadályozásáról szólnak. Amennyiben módosítás történik az Alap Rendelethez csatolt mellékletekben, így új faj kerül a listára, bizottsági módosító rendelet kerül elfogadásra. A három fő rendelet szabályozását egészítik ki a nem kötelező jogi normaként megjelenő bizottsági ajánlások, amelyek az EU vadvilág kereskedelmi szabályozásának végrehajtására vonatkozó iránymutatásokat részletezik. Utóbbiak elsősorban a tagállamok számára jelentenek segítséget a normák hatékony megvalósítása érdekében. Bár ez EU vadvilági kereskedelemre vonatkozó rendeletei (EU Wildlife Trade Regulations) közvetlenül hatályosak és

${ }^{533}$ HL L 166., 2006.6.19., 1-69. p. CELEX-szám: 32006R0865.

${ }^{534}$ HL L 242., 2012.9.7., 13-45. p. CELEX-szám: 32012R0792.

${ }^{535}$ HL L 271., 2017.10.20., 7-24. p. CELEX-szám: 32017R1915.

536 A Bizottság Közleménye az Európai Parlamentnek, a Tanácsnak, az Európai Gazdasági és Szociális Bizottságnak és a Régiók Bizottságának A vadon élö állatok és növények jogellenes kereskedelme elleni uniós cselekvési terv. Brüsszel, 2016.2.26. COM (2016) 87 final [Továbbiakban: Cselekvési terv]. 
alkalmazandók, a végrehajtási intézkedések meghozatala nagymértékben a tagállami szabályozáson nyugszik. Így a tagállami szintű jogalkotásnak is fontos szerepe van.

A vadvilági kereskedelemre vonatkozó rendeleteken túl nagy jelentősége van az Európai Unió legfontosabb célkitüzéseit tartalmazó cselekvési tervének. Az Európai Parlament 2014-ben fogadott el egy állásfoglalást, amely a cselekvési terv megalkotását szorgalmazta. ${ }^{537}$ A Parlament „sürgeti a Bizottságot, hogy haladéktalanul dolgozzon ki uniós cselekvési tervet a vadon élö növényekkel és állatokkal kapcsolatos büncselekmények és kereskedelem ellen, egyértelmüen meghatározva az elérendö eredményeket és az időkereteket is". ${ }^{538}$ Az Európai Bizottság 2014 februárjában indította el a vadon élő állatok és növények jogellenes kereskedelmének uniós megközelítéséről tartott konzultációt, amely keretében számos uniós tagállam, nemzetközi szervezet, nem kormányzati szervezet és érintett vállalkozás fejezte ki támogatását. ${ }^{539}$ A cselekvési terv elsőként arra hívja fel a figyelmet, hogy a vadon élő állat- és növényfajokkal való jogellenes kereskedelem a szervezett bünözés egyik legjövedelmezőbb formája lett, mintegy 8 és 20 milliárd euró közti éves nyereséggel. A világszerte elharapódzó probléma egyik fő eleme az afrikai illegális elefántcsontkereskedelem. A cselekvési terv utal a fő problémákra, így a jogellenes kereskedelem negatív hatására a jogállamiságra, a bünözésre és az érintett térségek biztonságára nézve. A cselekvési terv ezen túl reflektál a jelenséget övező nagy nemzetközi figyelemre és állást foglal az Unió szerepvállalása tekintetében. ${ }^{540} \mathrm{Az}$ uniós cselekvési terv olyan intézkedések sorozata, amelyeket az EU intézményeinek és/vagy tagállamainak kell megalkotniuk. Azonban az előbbiek támogatásához elengedhetetlen a megfelelő pénzügyi és emberi erőforrás rendelkezésre bocsátása. Emiatt a tervek mindig rendelkeznek a már meglévő erőforrások jobb kihasználhatóságáról és elosztásáról. ${ }^{541}$ A cselekvési terv rendelkezései három prioritáson alapulnak. ${ }^{542} \mathrm{Az}$ egyes prioritásokhoz azonban pontos célkitüzések és intézkedések kapcsolódnak, meghatározva az azért felelős uniós intézményt és/vagy tagállamokat. ${ }^{543} 2016$ júniusában az Európai Unió Tanácsa véleményt

${ }^{537}$ Az Európai Parlament 2014. január 15-i állásfoglalása a vadon élő növényekkel és állatokkal kapcsolatos büncselekményekről. 2013/2747(RSP) [Továbbiakban: Állásfoglalás, 2013/2747(RSP)].

538 Állásfoglalás, 2013/2747(RSP) Fellépés az EU-n belül 9. pont.

${ }^{539}$ Cselekvési terv 5. p.

${ }^{540}$ Cselekvési terv 3-5. p.

${ }^{541}$ Cselekvési terv 5. p.

542 : 1) a vadon élő állatok és növények jogellenes kereskedelmének megakadályozása és a kiváltó okok kezelése; 2) a meglévő szabályok eredményesebb végrehajtása és betartatása, valamint a vadon élő állatokkal és növényekkel kapcsolatos szervezett bünözés elleni hatékonyabb küzdelem; és 3) a származási, célés tranzitországok közötti, a vadon élö állatok és növények jogellenes kereskedelme elleni globális partnerség megerősítése. Cselekvési terv 6. p.

${ }^{543}$ Cselekvési terv 9-23. p. 
fogadott el a cselekvési tervhez kapcsolódóan, amelyben felhívást intézett az időben történő megvalósítás érdekében. ${ }^{544}$ Az előbbi dokumentumban a Tanács is megemlékezett a vadvilági kereskedelem és a szervezett bünözés kapcsolatáról és felszólította az Európai Rendőrségi Hivatalt, hogy vegye megfontolás alá a vadvilági bünözés kérdését a soron következő SOCTA elkészítése során. A környezeti bűncselekményekre és az energiacsalásra pedig az Európai Unió belső biztonságát fenyegető veszélyként tekint. ${ }^{545}$ Ugyancsak megjelenik a vadvilági online kereskedelem kérdése, beleértve a „darkweben” terjedő illegális tranzakciók mértékét. ${ }^{546} \mathrm{Az}$ Európai Parlament is reflektált ${ }^{547}$ a cselekvési terv elfogadására, különösen hangsúlyozva az EU jelentőségét, mint célpiac, származási és tranzitpont. A tagállamok számára elővigyázatos megközelítést javasol a védett fajok vadászati trófeáinak behozatala tekintetében, hiszen a CITES I. és II. Függelékeibe sorolt fajok pusztulásához nagymértékben hozzájárult a trófeáért folytatott vadászati tevékenység. ${ }^{548}$ A dokumentum érdekessége, hogy külön kiemeli a létező kereskedelmi együttmüködések környezeti vonatkozásait és szorgalmazza a CITES és a WTO közötti kooperáció megerősítését, különös tekintettel a fejlődő országok tisztviselői számára a kereskedelmi és környezetvédelmi területen nyújtott technikai segítség és kapacitásépítés tekintetében. ${ }^{549}$ 2017-ben az Európai Parlament állasfoglalást hozott az Európai Unió és Afrika közötti stratégiáról. Az állásfoglalásban utalás történik a környezeti területen való ellenálló képesség fejlesztésére és hangsúlyozza az afrikai kontinensen a biológiai sokféleség védelmét és megállapítja, hogy az EU-Afrika stratégia a vadon élő állatok és növények jogellenes kereskedelme elleni uniós cselekvési terv prioritásaival összhangban kell, hogy müködjön és védelmeznie kell a természeti örökséget, különösen a természetvédelmi területeket és nemzeti parkokat. ${ }^{550}$

\footnotetext{
${ }^{544}$ Tervezet - A Tanács következtetései a vadon élő állatok és növények jogellenes kereskedelme elleni uniós cselekvési tervről - A következtetések elfogadása. Council Conclusions 10512/16 2016. június 21. Brüsszel [Továbbiakban: Conclusion, 10512/16]

${ }^{545}$ Conclusion, 10512/16 6. 18. p.

${ }^{546}$ Conclusion, 10512/16 6. 20. p.

${ }^{547}$ Az Európai Parlament 2016. november 24-i állásfoglalása a vadon élő állatok és növények jogellenes kereskedelme elleni uniós cselekvési tervröl 2016/2076(INI) (HL C 224., 2018.6.27., 117-126. p.) CELEX-szám: 52016 IP0454 [Továbbiakban: Állásfoglalás, 2016/2076(INI)].

548 Állásfoglalás, 2016/2076(INI) 56. pont.

549 Állásfoglalás, 2016/2076(INI) 50. pont.

${ }^{550}$ Az Európai Parlament 2017. november 16-i állásfoglalása az EU-Afrika stratégiáról: a fejlődés fellendítése 2017/2083(INI) (HL C 356., 2018.10.4., 66-76. p.) CELEX-szám: 52017IP0448, 27. pont.
} 


\section{V.4. Főbb különbségek a CITES és az EU vadvilági kereskedelemre vonatkozó szabályozása között}

Bár legtöbb esetben az Európai Unió és a Washingtoni Egyezmény normái átfedik egymást, már az 1982-es uniós rendelet is néhány tekintetben szigorúbb szabályokat határozott meg, mint a nemzetközi egyezmény. A különbségek tekintetében ez a tendencia folytatódott és az Unióban szigorúbb követelményekkel találkozunk, mint nemzetközi szinten. Ezt kiegészítve azzal, hogy több tagállamban is, a vadvilági kereskedelem egyes területein, szigorúbb szabályozás van, mint ami az uniós jogból fakadna.

A legfontosabb differencia a CITES-hez kapcsolódó három függelék és a 338/97/EK rendelet négy melléklete között van. Az Európai Unió vadon élő fajok kereskedelmét szabályozó rendeletének négy melléklete van (A, B, C és D). Az A, B és C melléklet körülbelül megfelel a már korábban említett CITES I., II. és III. Függelékeinek. Azonban a mellékletek tartalmaznak a CITES által fel nem sorolt fajokat is, amelyeket csak az EU belső szabályai védenek. Ezen túl a D melléklet, amelynek tehát nincs megfelelője a CITESben, olyan fajokat sorol fel, amelyeket lehet, hogy valamely másik mellékletbe kell majd felvenni, és amelyeknek ezért az EU-ba történő behozatalát megfigyelés alatt tartják, így erre gyakran „megfigyelési listaként” hivatkoznak.

Összevetve tehát a mellékleteket és a CITES Függelékeit, a következö megállapitások tehetök:

A. Ide sorolható be minden, a CITES I. Függelékében felsorolt faj, kivéve, ha az EU tagállamok fenntartást nyújtottak be. Néhány a CITES II. és III. Függelékében felsorolt faj, amelyekre az EU szigorúbb belső intézkedéseket fogadott el, valamint egyéb, a CITES által fel nem sorolt fajok.

B. Minden olyan, egyébként a CITES I. Függelékében felsorolt faj, amelyekre vonatkozóan az EU tagállamok fenntartást nyújtottak be. Minden más a CITES II. Függelékében felsorolt faj, kivéve, ha az EU tagállamok fenntartással éltek. Valamint egyéb, a CITES III. Függelékében található fajok és más, a CITES által fel nem sorolt fajok.

C. Minden a CITES II. Függelékében felsorolt faj, ha az EU tagállamok fenntartást nyújtottak be. Ezen túl más a CITES III. Függelékében felsorolt fajok, kivéve, ha az EU tagállamok fenntartást nyújtottak be. 
D. Olyan fajok, amelyek a CITES III. Függelékében vannak, de az EU tagállamok fenntartással éltek. Egyéb fajok, amelyek a CITES Függelékekben nem szerepelnek, de az EU területén megfigyelési listára kerültek. ${ }^{551}$

Azonban a CITES és az EU szabályozása között több más érdemi különbség is megállapítható. Így másodsorban az import követelmények eltéréseit kell kiemelni. Importengedély szükséges az 'A' mellékletben felsorolt fajok esetében. Azonban az uniós szabályozás szigorúbb importfeltételeket állapít meg, mint a CITES által megköveteltek. Így az importengedély nemcsak az 'A' mellékletben felsorolt fajok esetében elöírás, hanem a 'B' mellékletben szereplőknél is. A CITES csupán az I. Függelékbe sorolt fajok esetében követeli meg az importengedélyt. Ezen túl ún. importbejelentések szükségesek a 'C' és a 'D' mellékletben felsorolt fajok behozatala esetén is. Az importnyilatkozat egy bejelentés az importőr által, amelyet a megfelelő tagállami vámügyi hivatalhoz kell benyújtani, ahol szükséges a CITES III. Függelékéhez kapcsolódó dokumentációval egyetemben. Az importbejelentés szabályait részletesen tartalmazza az Engedélyezési Rendelet. A legszigorúbb standardokat megkövetelő 'A' és a 'B' mellékletben felsorolt fajok élő példányait kizárólag akkor lehet az Unió területére behozni, ha a címzett bizonyíthatóan megfelelő feltételekkel rendelkezik a példányok tartásához és gondozásához. Míg a CITES csak az I. Függelékben megadott fajok élő példányainak importjánál írja ezt elő. Mivel az uniós szabályozás egyes, a II. Függelékben szereplő fajokat az 'A' mellékletbe sorol, a nemzetközi szabályoktól eltérően, ezekkel nem lehet kereskedni, vagy ezeket kereskedelmi célra használni.

A kereskedelem területét illetően az Unió szabályozása az EU tagállamokon belüli és a tagállamok közötti kereskedelmet, vagyis a belső kereskedelmet, valamint a nem EU tagállamokkal történő kereskedelmet egyaránt szabályozza, míg a CITES csak a nemzetközi kereskedelmet. Tekintettel a belső piacra és az áruk, termékek szabad mozgására, az Európai Unióban speciális szabályokat kellett elfogadni az egyes tagállamokon belüli és a tagállamok közötti kereskedelemre, így különösen a legszigorúbb védelmet élvező 'A' listás fajok tekintetében külön szabályokat határoztak meg. A szabályozás indoka, hogy a rendelet hatálya alá tartozó fajoknak a lehető legszélesebb körü védelmet kívánják biztosítani és ennek érdekében szabályokat kellett meghatározni a fajok Közösségen belüli

${ }^{551}$ The Differences between EU and CITES Provisions in a Nutshell 1.o. http://ec.europa.eu/environment/cites/pdf/differences_b_eu_and_cites.pdf. (2018.09.24.) [Továbbiakban: Különbségek]. 
kereskedelmének és szállításának ellenőrzésével, valamint a példányok tartására vonatkozó feltételekkel kapcsolatosan. Ezt segíti elő, hogy az Alap Rendelet alapján kiállított, e tevékenységek ellenőrzését elősegítő tanúsítványok megadására, érvényességére és használatára közös szabályok kerültek kialakításra. ${ }^{552}$ Az Alap Rendelet felhatalmazza a tagállamokat, hogy felfüggesszék az importot bizonyos fajok és országok tekintetében még akkor is, ha a kereskedelem a CITES alapján engedélyezett. Utóbbihoz szükséges a Tudományos Felülvizsgálati Csoport negatív véleménye. A döntés az EU import felfüggesztések formájában jelenik meg. Az Alap Rendelet felhatalmazza a Bizottságot, hogy meghatározott fajok importját adott államokból akkor is felfüggessze, ha egyébként a kereskedelem a CITES alapján engedélyezett lenne. ${ }^{553}$

Az Alap Rendelet lehetőséget biztosít arra, hogy az Európai Unió területére történő behozatal tekintetében korlátozásokat foganatosítsanak. ${ }^{554}$ Így az Európai Bizottságnak joga van arra, hogy egyes fajoknak az EU-ba történő „,behozatalát általánosságban vagy bizonyos származási országok vonatkozásában korlátozza". 555

Az Európai Unió területére történő behozatal vonatkozásában az Alap Rendelet szigorú feltételeket állapít meg, milyen esetekben adhatják meg a tagállamok hatóságai a behozatali engedélyt. Természetesen, a legszigorúbb követelmények az 'A' mellékletben listázott fajok tekintetében kerültek meghatározásra. Az import felfüggesztéséhez elsődlegesen a Tudományos Felülvizsgálati Csoport negatív véleményalkotása szükséges és az illetékes származási állammal vagy államokkal is konzultálni kell. Negatív véleményt akkor formálhatnak, ha az importról úgy ítélik meg, hogy káros hatása van a faj fennmaradására. Ha egyszer negatív véleményt bocsátottak ki, akkor importengedélyek nem adhatók ki az adott államból származó fajokra. A negatív vélemény azonban időszakos jellegü és amint új információ érhető el a faj kereskedelméről vagy természetvédelmi státuszáról az érintett országban, valamint a felmerült aggodalmakat eloszlatták, az visszavonható.

A Bizottság részéről lehetőség adódik a hosszú távú importfelfüggesztésre is, mikor a hivatalos lapban közzétett felfüggesztő rendelet elfogadására kerül sor. A hosszú távú importfelfüggesztést a negatív véleményhez hasonlóan akkor alkalmazzák, ha az

\footnotetext{
552 Alap Rendelet (10) bekezdés.

${ }^{553}$ A vadon élö fajok kereskedelmének szabályozása az Európai Unióban Bevezetés a Washingtoni Egyezménybe és végrehajtásába az Európa Unióban. Luxembourg: Az Európai Közösségek Hivatalos Kiadványainak Hivatala, 2007. ISBN 978-92-79-05432-7 13. p. [Bevezetés a Washingtoni Egyezménybe, 2007.]. ${ }_{554}$ Alap Rendelet 4. cikk $A$ Közösség területére történö behozatal.

555 Alap Rendelet 4. cikk (6) bekezdés.
} 
importról úgy ítélik meg, hogy káros hatással van a fajok természetvédelmi helyzetére, és ha a kérdéses ország nem szolgáltatott azt cáfoló információt. Ezen túl az Alap Rendelet tételesen meghatározza, hogy mikor kerülhet sor felfüggesztő rendelet elfogadására. ${ }^{556}$ $\mathrm{Az}$ 'A' mellékletben meghatározott fajok esetében két eshetôség áll fent. Egyrészt az illetékes tudományos testület a Tudományos Felülvizsgálati Csoport véleményének figyelembevétele alapján úgy ítéli meg, hogy a Közösség területére történő behozatal hátrányosan befolyásolja a fajok természetvédelmi helyzetét. ${ }^{557}$ Másrészt az érintett fajok populációja által elfoglalt terület kiterjedését vagy az igazgatási hatóság az illetékes tudományos testülettel lefolytatott konzultáció alapján megbizonyosodott arról, hogy a behozatali engedély megadását meghiúsító, a fajok védelmét befolyásoló egyéb ok áll fenn. ${ }^{558}$ A 'B' mellékletben felsorolt fajokkal kapcsolatosan vagy az egyéb védelmet befolyásoló ok áll fent, vagy megállapításra kerül, hogy a kereskedelem jelenlegi és várható mértékét figyelembe véve a fajok természetvédelmi helyzetét vagy az érintett fajok populációja által elfoglalt terültet a behozatal hátrányosan befolyásolja. ${ }^{559} \mathrm{Az}$ élő egyedek tekintetében további megszorítások vannak, ha azok a 'B' mellékletben kerültek listázásra és roszszul türik a szállítást vagy fogságot, ${ }^{560}$ illetve ha bevitelük ökológiai fenyegetést jelent az Unió területén őshonos vadon élő állat és növényfajaira. ${ }^{561}$

A Bizottság az Európai Közösségek Hivatalos Lapjában negyedévente közzéteszi a hoszszú távú importkorlátozások listáját. ${ }^{562}$ A legutóbbi elfogadott rendelet az egyes vadon élő állat- és növényfajok példányai Unióba történő behozatalának tilalmáról szóló 1915/2017/EU bizottsági végrehajtási rendelet, amelyet 2017 októberében fogadtak el. Elődje a 2015/736/EU bizottsági végrehajtási rendelet, ${ }^{563}$ korábban a 2014

\footnotetext{
556 Bevezetés a Washingtoni Egyezménybe, 2007. 14. p.

557 Alap Rendelet 4. cikk (1) bekezdés a) i. alpont.

${ }^{558}$ Alap Rendelet 4. cikk (1) bekezdés e) pont.

559 Alap Rendelet 4. cikk (2) bekezdés a) pont.

${ }^{560}$, ,A B. mellékletben felsorolt olyan fajok élö egyedei vonatkozásában, amelyek magas halálozási arányt mutatnak a szállitás során, vagy azok vonatkozásában, amelyekröl megállapitásra került, hogy fogságban természetes élettartamuknak megfelelö időtartamot valószínüleg nem élik meg." Alap Rendelet 4. cikk (6) c).

561 „Az olyan fajok élö egyedeire, amelyekről megállapitották, hogy a Közösség természeti viszonyai közé történö bevitelük ökológiai fenyegetést jelent a Közösség öshonos vadon élö állat és növényfajaira." Alap Rendelet 4. cikk (6) bekezdés d) pont.

562 Alap Rendelet 4. cikk (6) bekezdés.

${ }^{563}$ A Bizottság (EU) 2015/736 végrehajtási rendelete (2015. május 7.) egyes vadon élő állat- és növényfajok példányai Unióba történő behozatalának tilalmáról. (HL L 271., 2017.10.20., 7-24. p.) CELEX-szám: 32015R0736 Érvényesség vége: 2017. 11. 08.
} 
augusztusában elfogadott 888/2014/EU bizottsági végrehajtási rendelet ${ }^{564}$ tartalmazta a tilalmi rendelkezéseket.

A tilalmi rendelet melléklete tartalmazza azokat a fajokat és származási országokat, ahonnan tilos az Európai Unió területére történt behozatal. Fő rendelkezései pedig a korábbi rendelet módosítására vonatkoznak. A rendelet néhány elemét kiemelve, tilos behozni az Alap Rendelet 'A' mellékletében szereplő fajok közül az EU területére: Üzbegisztánból vadon élő „Capra falconeri” (pödröttszarvú kecske) trófeáját; Oroszországból vadon élő „Ursus thibetanus” (örvös medve) trófeáját; vadon élő „Ursus actors” (barnamedve) trófeáját Kanadából és Kolumbiából; vadon élő „Canis lupus” (szürke farkas) trófeáját Fehéroroszországból, Mongóliából, Tádzsikisztánból és Törökországból; Kamerunból pedig vadon élő „Loxodonta africana” (afrikai elefánt) trófeáját. Jelenleg több száz faj tekintetében van hatályban állandó importkorlátozás, elsősorban a 'B' melléklet tekintetében. 565

A CITES Állandó Tanácsának üléseit követen a UNEP-WCMC ${ }^{566}$ biztosít összehasonlítást a CITES a II. Függelékbe sorolt fajok jelentős kereskedelmének felülvizsgálatára vonatkozó döntések és az EU döntések megfelelöségét illetően. Alapvetően az EU tagállamokban érvényben lévő kereskedelmi felfüggesztések alapulhatnak a CITES értesítéseken is, ahol az állam dönt a saját hatáskörben való felfüggesztésröl és arról értesíti a Titkárságot. ${ }^{567}$ Az Európai Unióban és a tagállamokban alkalmazott kereskedelmi felfüggesztések és a CITES értesítések összehasonlítására azért van szükség, hogy a Washingtoni Egyezmény rendszere és az európai integráció által alkalmazott korlátozások összehangban legyenek egymással. Mivel a vadvilági kereskedelemben az Európai Unió jelentős piacnak minősül, kiemelt jelentőséggel bír, hogy a nemzetközi szinten alkalmazott korlátozások alkalmazásra kerüljenek. Ugyanakkor mivel a CITES is lehetőséget biztosít, hogy a részes felek az előírtnál szigorúbb rendelkezéseket hozzanak a vadvilág védelme keretében, az Európai Unió a vadvilági kereskedelemre vonatkozó rendeletek alapján is

\footnotetext{
${ }^{564}$ A Bizottság 888/2014/EU végrehajtási rendelete (2014. augusztus 14.) egyes vadon élő állat- és növényfajok példányai Unióba történő behozatalának tilalmáról (HL L 243., 2014.8.15., 21-38. p.) CELEXszám: 32014R0888 Érvényesség vége: 2015. 05. 28.

565 Az előző tilalmi rendelethez képest például feloldották a Guyanából a „Palaeosuchus trigonatus” (Schneider-törpekajmán) vadon élő bármilyen példányára vagy származékára vonatkozó tilalmat, az „Orchis pallens" (sápadt kosbor) vadon élő példányaira, vagy azok bármely megjelenési formájára vonatkozó tilalmat, Oroszországot illetően.

${ }^{566}$ World Conservation Monitoring Centre.

${ }^{567}$ UNEP-WCMC technical report. Comparison of EU decisions and CITES suspensions - identification of any outstanding potential discrepancies. UNEP-WCMC Cambridge, 2016. 1. p.
} 
hozhat meghatározott országokra és fajokra vonatkozó tilalmakat. Utóbbiak jelennek meg az Európai Bizottság tilalmi rendeleteiben.

Az Európai Unió és a CITES szabályozása nagyrészben megfeleltethető egymásnak, azonban egyes kérdésekben az uniós jog szigorúbb kötelezettségeket támaszt. Azonban ez a különbség nem az EU Washingtoni Egyezményben való részes féllé válásával függ össze, hiszen már az 1982-es rendelet is ebbe az irányba mutatott. A mindennapi jogalkalmazás egyik legfontosabb követelménye, hogy a kereskedelmi korlátozások megfelelően alkalmazásra kerüljenek az Európai Unióban. 


\section{V.5. A bürokrácia útvesztői - vadvilági kereskedelem a belső pia- con és harmadik államokkal}

Jelen értekezés célkitüzéseiből nem következik az Európai Unió vadvilági kereskedelemre vonatkozó minden szabályának részletes elemzése, különösen a dokumentumok és engedélyek rendszerét tekintve. Azonban a vadvilági kereskedelem jelentősége az uniós piacon és a belső piac eredményeképpen létrejött összetett rendszer bonyolultsága, szükségessé teszik, hogy legalább a belső piacra történő behozatal és a kereskedelmi folyamatok elemzésre és értékelésre kerüljenek.

\section{V.5.1. Fogalmi alapvetések}

Az egyes kereskedelmi tevékenységek pontos fogalmát a rendeletek határozzák meg. Így a kereskedelem tekintetében a legfontosabb fogalmak tisztázása nélkülözhetetlen. A származási ország olyan ország, amelyben a példányt a vadonból fogták be, fogságban tenyésztették vagy mesterségesen szaporították. ${ }^{568}$ Rendeltetési tagország egy példány kiviteléhez vagy újrakiviteléhez használt okmányban megnevezett rendeltetési tagállam vagy tengerről való behozatal ${ }^{569}$ esetében pedig az a tagállam, amelynek joghatósága alá a példány rendeltetési helye tartozik. ${ }^{570}$ A rendeltetési hely az a hely, amelyet az EU-ba történő behozatal időpontjában normális tartási helynek feltételeznek. Az élő példányok esetében pedig ez azon első hely, ahol azokat - valamely egészségügyi vizsgálat, vagy ellenőrzés elvégzésére szolgáló karantént vagy más elhelyezést követően - tartják. ${ }^{571} \mathrm{~A}$ behozatali jelentés olyan nyilatkozat, amelyet az importőr ügynöke vagy képviselöje tesz a 'C' vagy 'D' mellékletben felsorolt fajok valamely példányának Európai Unióba történő behozatalakor a Bizottság által előírt eljárásnak megfelelően meghatározott ürlapon. ${ }^{572}$ Az Európai Unió területéről történő újrakivitel egy korábban behozott példány kivitelét jelenti. ${ }^{573}$ Az EU-ba történő ismételt behozatal egy korábban kivitt vagy újrakivitt példány behozatala. ${ }^{574}$ Mivel a rendeletek a lehető legszélesebb körü védelmet igyekeznek

\footnotetext{
568 Alap Rendelet 2. cikk c) pont.

${ }^{569}$, „Az egyetlen állam fennhatósága alá sem tartozó tengeri környezetben - beleértve a tenger feletti légteret, a tengerfeneket és a tengerfenék alatti altalajt - befogott példány közvetlen behozatala a Közösségbe." Alap Rendelet 2. cikk e)

570 Alap Rendelet 2. cikk h) pont.

${ }^{571}$ Alap Rendelet 2. cikk k) pont.

572 Alap Rendelet 2. cikk d) pont.

${ }^{573}$ Alap Rendelet 2. cikk n) pont.

${ }^{574}$ Alap Rendelet 2. cikk o) pont.
} 
biztosítani, a példány fogalmát is az egyes fajok minden megjelenési formájára kiterjesztették azok bármely, élő vagy elhalt, állati vagy növényi egyedére, ezek bármely részére vagy származékára. ${ }^{575}$ Ezt az elvet követi a CITES is, hiszen az Egyezmény fogalma is minden megjelenési formára vonatkozik.

\section{V.5.2. A megfelelő dokumentáció követelménye}

A behozatalhoz és a kivitelhez szükséges iratok csak meghatározott esetekben és követelmények teljesülése esetén bocsáthatók ki. A feltételeket a tagállami igazgatási hatóságok a tudományos hatóságokkal együttmüködve vizsgálják meg. A dokumentumok bemutatásra kell, hogy kerüljenek a megfelelő vámhivatal előtt, mielőtt a szállítást engedélyezik az EU területére vagy annak területéröl. Az Alap Rendelet is felhívja a figyelmet az egységes dokumentáció szükségességére: a rendeletek végrehajtásához azonos feltételeket kell megállapítani a rendelet által érintett fajok példányainak a Közösségbe történő behozatalának, kivitelének vagy újrakivitelének engedélyezésével kapcsolatos okmányok megadására, használatára és bemutatására vonatkozóan. ${ }^{576}$ Amennyiben a vadvilági termékek vagy fajok kereskedelmét tekintjük, elsődleges forrásként a már megnevezett vadvilági rendeletek szolgálnak. Azonban bizonyos esetekben, különösen élelmiszernek minősülő termékek (pl. tengeri herkentyük, kaviár), élő állatok, valamint állati termékek (egészségügyi, valamint állat- és növény egészségügyi okok miatt) esetében egyéb követelményeket is teljesíteni kell a jogszerü szállításhoz és kereskedelmi tevékenységhez. ${ }^{577}$ Alapvető kitétel, hogy minden, az Alap Rendelet 'A', 'B' vagy 'C' mellékletbe sorolt faj Európai Unióba történő behozatalához, vagy onnan történő kiviteléhez megfelelő dokumentumokra van szükség. Főszabály szerint a ’D' mellékletben listázott faj esetén csak a

\footnotetext{
${ }^{575}$ Az A-D. mellékletben felsorolt fajok bármely, élö vagy elhalt, állati vagy növényi egyede vagy ezek bármely része vagy származéka attól függetlenül, hogy ezek más árukban találhatók-e vagy sem, valamint valamennyi olyan más termék, amely esetén a kisérö okmányból, a csomagolásból, a megjelölésböl vagy címkéböl vagy bármely máskörülményböl következik, hogy az ezen állat-vagy növényfaj részeinek vagy származékainak minösül, illetve azokat tartalmaz, kivéve ha az ilyen rész vagy származék nem tartozik e rendelet elöírásai vagy azon mellékletére vonatkozó elöírás hatálya alá, amelyben az érintett fajt az emlitett mellékletben egy idevonatkozó adat alapján nevezték meg. Példánynak tekintendö az A-D. mellékletben felsorolt fajok egy példánya, amennyiben az olyan állat vagy növény, illetve annak részei és származékai, amelynek legalább egyik ,szülöje” a felsorolt fajok egyikébe tartozik. Azokban az esetekben, amikor egy ilyen állatnak vagy növénynek a „szülei” a különbözö mellékletekben felsorolt fajokba vagy olyan fajokba tartoznak, amelyek közül csak az egyiket sorolják fel, az erösebb korlátozást jelentö melléklet elöirásait kell alkalmazni. Azonban növények hibrid példányai esetén, ha a ,szülök” egyike az A. melléklet szerinti fajba tartozik, az erösebb korlátozást jelentö mellékletet csak akkor kell alkalmazni, ha e fajra a melléklet egy idevonatkozó utalást tartalmaz. Alap Rendelet 2. cikk t) pont

576 Alap Rendelet (5) bekezdés.

${ }^{577}$ Reference Guide, 2017. 21. p.
} 
példány EU területére történő behozatalakor van szükség az iratokra, kivéve, ha egyben a faj szerepel a CITES III. számú Függelékében is.

A jogszerü vadvilági kereskedelmi tevékenység alapját a tevékenységhez szükséges dokumentáció képezi. A különböző iratok rendszerét a vadvilág kereskedelmi rendeletek szabályozzák. Behozatali engedély szükséges az 'A' és 'B' mellékletekben felsorolt példányok behozatalához. ${ }^{578}$ Kiviteli engedély szükséges az 'A', 'B' és 'C' mellékletben szereplő példányok exportjához. ${ }^{579}$ Újrakiviteli bizonyítvány szükséges az 'A', 'B' és 'C' mellékletben szereplő példányok újrakiviteléhez ${ }^{580}$. Valamint, az import engedély előzetes bemutatása szükséges a 'C' és 'D' mellékletekben felsorolt fajok egyedeinek az Unió területére történő behozatalához. ${ }^{581}$ Különös esetekben az engedélyek helyett bizonyítványok alkalmazandóak, például oktatási célú példányok, cirkuszok és utazó kiállítások, botanikus kerti példányok és állatkerti példányok esetében. ${ }^{582}$

Az EU igazgatási hatóságai által kiállított dokumentumokon túl, szükséges lehet az újrakivitel, kivitel vagy import ország által biztosított iratokra is. Így az 'A' és 'B' mellékletben felsorolt példányok behozatala esetében, amennyiben azok a CITES függelékekben is szerepelnek, a származási hely, vagy az újrakivitel szerinti ország által kiadott export, illetve újrakiviteli engedély is szükséges. Még szigorúbb szabályok vonatkoznak azon esetekre, ha a faj az I. Függelékben szerepel, mivel ilyenkor a célállam által kiadott importengedély bemutatása szükséges a kiviteli engedély kiállításához. ${ }^{583}$

A vadvilággal kapcsolatos büntetendő cselekmények következtében egyes fajok a kihalás szélére sodródtak. Ezeknek a fajoknak a nemzetközi közösség különleges védelmet kíván biztosítani, így a CITES is különösen szigorú szabályokat állapít meg a példányokkal való kereskedelem tekintetében. Ezen oknál fogva, illetve az Európai Unió területéhez kapcsolódó kereskedelmi tevékenységhez szükséges, sokszor bonyolult dokumentációs követelmények miatt, külön ajánlások és útmutatók kerültek kidolgozásra. A Bizottság közlemény formájában fogadott el útmutató dokumentumot, 2016-ban az orrszarvúszarvak kivitele, újrakivitele, behozatala és Unión belüli kereskedelme tekintetében. ${ }^{584} \mathrm{~A}$ Bizottság iránymutatást fogadott el az elefántcsont Unión belüli kereskedelme és re-

\footnotetext{
578 Alap Rendelet 4. cikk (1) és (2) bekezdések.

${ }^{579}$ Alap Rendelet 5. cikk (1), (2) és (4) bekezdések.

${ }^{580}$ Alap Rendelet 5. cikk (1), (2) és (4) bekezdések.

581 Alap Rendelet 4. cikk (3) és (4) bekezdések.

${ }^{582}$ Végrehajtási Rendelet 5. cikk (5), IX. melléklet 1. B-Z pontok.

${ }^{583}$ Alap Rendelet 5. cikk (2) c) ii. „Az igazgatási hatóság megbizonyosodott arról, hogy az egyezményben részes fél államába történö kivitele esetében a behozatali engedélyt kiadták."

${ }^{584}$ A Bizottság közleménye (2016/C 15/02).
} 
exportja témakörben. ${ }^{585}$ Valamint, 2017-ben megalkotásra került az iránymutatás a megmunkált példányokhoz a vadon élö állat- és növényfajok kereskedelmét szabályozó uniós rendeletek alapján. ${ }^{586}$

\section{V.5.3. Behozatal az Európai Unió területére}

Mivel az egyes mellékletek különböző mértékü védelmet biztosítanak a fajoknak, az Európai Unióba történő behozatali eljárás is eltéréseket mutat. Az 'A' és 'B' mellékletekben felsorolt fajokra más szabályok vonatkoznak, mint a 'C' és a 'D' mellékletekben listázottakra.

Az 'A' és 'B' mellékletekben található fajok behozatala érdekében az importőrnek be kell nyújtani a behozatali engedély iránti kérelmet a tagállam igazgatási hatóságához, a megfelelö formanyomtatvány pontos kitöltésével. Ez Magyarországon azt jelenti, hogy a kérelmet a vámhatósághoz kell benyújtania. ${ }^{587} \mathrm{~A}$ tagállamok hatóságainak döntése alapján lehetőség van arra, hogy egynél több szállítmány is egy formanyomtatvány benyújtása alapján kerüljön engedélyezésre. ${ }^{588}$ Azonban az egy rakomány részeként behozatalra kerülő példányok esetében minden szállítmány külön importengedélyt követel meg. ${ }^{589} \mathrm{~A}$ rakomány részeként szállított különböző fajokra vonatkozóan külön mellékletet kell a formanyomtatványhoz csatolni. ${ }^{590} \mathrm{Az}$ importengedély iránti kérelmet megfelelő időben kell kérelmezni ahhoz, hogy lehetőség legyen azok kiadására a példányoknak az Unióba történő importjára. ${ }^{591}$ A bizonyítványok és engedélyek kitöltésekor speciális kódokat és referenciákat használnak. Így a példányok leírására és tömegük megadására, az egyes fajok tudományos nevének leírására, a behozatal céljának megállapítására és a példányok eredetének igazolására. ${ }^{592}$ A tagállamok igazgatási hatóságát is határidők kötik, mivel a teljes kérelem benyújtásának napját követő egy hónapon belül kell dönteniük az engedélyek, bizonyítványok és bizonylatok kiadásáról. Amennyiben szükséges, hogy a kiállító hatóság harmadik országgal konzultáljon, akkor a döntés csak a konzultáció eredményes

585 A Bizottság közleménye (2017/C 154/06) Iránymutatásokat tartalmazó dokumentum: Az elefántcsont Európai Unión belüli kereskedelmét és újrakivitelét szabályozó uniós rendszer (HL C 154., 2017.5.17., 414. p.) CELEX-szám: 52017XC0517(01).

${ }^{586}$ A Bizottság közleménye (2017/C 154/07) Iránymutatás a megmunkált példányokhoz a vadon élő állatés növényfajok kereskedelmét szabályozó uniós rendeletek alapján (HL C 154., 2017.5.17., 15-26. p.) CELEX-szám: 52017XC0517(02).

${ }^{587}$ Végrehajtási Rendelet IV. Fejezet Importengedélyek.

${ }^{588}$ Végrehajtási Rendelet 20. cikk (1) bekezdés.

589 Végrehajtási Rendelet 9. cikk.

${ }^{590}$ Végrehajtási Rendelet 6 . cikk (2) bekezdés.

${ }^{591}$ Végrehajtási Rendelet 13. cikk (1) bekezdés.

592 Végrehajtási Rendelet 5. cikk. 
befejezését követően hozható meg. Ilyen esetekben a kérelmezöket értesíteni kell a kérelmeik feldolgozásának lényeges késedelméről. ${ }^{593}$ Kiegészítő szabályként a rendelet előírja, hogy a behozatal tárgyát képző példányok nem nyújthatók be vámeljárás céljára, amíg a szükséges dokumentumokat be nem mutatták. ${ }^{594}$

Az igazgatási hatóságok számára az Alap és a Végrehajtási Rendeletekben meghatározott dokumentációt kell benyújtani, amelyek a CITES szabályok alapján kerültek meghatározásra. Az I. és II. Függelékben felsorolt fajok esetében a kérelmezőnek írásos bizonyítékkal kell tanúsítania, hogy a példányokat az érintett fajokra vonatkozó védelmi jogszabályokkal összhangban szerezte be. Ezt az Egyezmény függelékeiben felsorolt fajok egyedeinek harmadik országból történő behozatala esetében kiviteli engedély vagy újrakiviteli bizonyítvány, valamint ezek másolata bizonyíthatja, amelyet a kiviteli vagy újrakiviteli ország illetékes hatósága adott ki az Egyezményben foglaltakkal összhangban. ${ }^{595}$ Ezt kiegészítő szabály, hogy az 'A' mellékletben felsorolt fajok esetében a behozatali engedély kiadásának nem szükséges feltétele a fenti írásos bizonyíték megléte, de a behozatali engedély eredeti példányát a kérelmező nem kaphatja meg addig, amíg a kiviteli engedélyt vagy az újtakiviteli bizonyítványt be nem mutatja. ${ }^{596}$ A III. Függelékben felsorolt fajok esetében, ha a kivitel olyan államból történik, ahol a faj szerepel a függelékben, szükséges a kiviteli engedély. ${ }^{597}$

Egyes vadvilági termékek tekintetében külön rendeletekben is történik utalás a CITES által védett fajok kereskedelmének egyéb szabályaira. Így történik például a 995/2010/EU Rendeletben a fát és fatermékeket piaci forgalomba bocsátó piaci szereplők kötelezettségeinek meghatározásáról. Az említett rendelet szól arról, mi minősül legálisan kitermelt faanyagnak, ha az említett fajok az Alap Rendelet valamely mellékletében szerepelnek. ${ }^{598}$ A kitöltött formanyomtatványt vagy nyomtatványokat a tagállamok igazgatási hatóságához kell benyújtani. Az igazgatási hatóság a rendelkezésére bocsátott dokumentáció és az egyéb megszerzett információk alapján dönt az importengedély kibocsátásáról. Az importengedélyeket papír vagy elektromos formában bocsátják ki. Meghatározott esetekben az igazgatási hatóság köteles a tudományos hatósággal is konzultálni, a behozatal

\footnotetext{
${ }^{593}$ Végrehajtási Rendelet 8. cikk (3) bekezdés.

${ }^{594}$ Végrehajtási Rendelet 13. cikk (2) bekezdés.

595 Alap Rendelet 4. cikk (2) bekezdés b) pont.

596 Alap Rendelet 4. cikk (2) bekezdés b) ii) alpont.

${ }^{597}$ Alap Rendelet 4. cikk (3) bekezdés b) pont.

598 3. cikk A FLEGT és a CITES hatálya alá tartozó fa és fatermékek jogi helyzete: „A 338/97/EK rendelet A., B. vagy C. mellékletében felsorolt fajok olyan faanyaga, amely megfelel az említett rendeletnek és végrehajtási rendelkezéseinek, e rendelet alkalmazásában legálisan kitermeltnek minősül.”
} 
engedélyezése előtt, például állatfajok fogságban született, illetve szaporított példányai esetében. ${ }^{599}$

Az EU vadvilági kereskedelemmel foglalkozó rendeletei az EU területére történő behozatallal kapcsolatosan egyéb követelményeket is támasztanak. Általános szabály az, hogy a 'A' mellékletben felsorolt fajokat nem lehet elsődlegesen kereskedelmi célzattal importálni. ${ }^{600} \mathrm{Az}$ 'A' és 'B' mellékletekben felsorolt fajok Unió területére történő behozatalát csak akkor lehet engedélyezni, ha a tudományos testület, figyelembe véve a SRG véleményét is, megbizonyosodott arról, hogy az import nem befolyásolja hátrányosan a fajok természetvédelmi helyzetét vagy az érintett fajok populációja által elfoglalt terület kiterjedését. ${ }^{601}$ Olyan esetekben, mikor nem sikerül megfelelő információt szerezni az exportálás vagy újrakivitel helye tekintetében, hogy a példány jogszerüen került-e megszerzésre, nem lehet kibocsátani az importengedélyt. ${ }^{602}$ Egyes példányokat az EU-ba történő behozatal érdekében az Egyezmény részes feleinek konferenciája által az adott példányra vonatkozóan jóváhagyott vagy ajánlott módszerrel meg kell jelölni. ${ }^{603} \mathrm{Az}$ élő példányok tekintetében a tudományos hatóságnak meg kell bizonyosodnia arról, hogy a tervezett rendeltetési helyen az élő példányt annak megörzésére és gondozására megfelelően előkészített telephely várja. Amennyiben az 'A' mellékletben felsorolt fajok élő példányainak behozatalára kérnek engedélyt, a formanyomtatvány megfelelő „dobozában” részletezni kell a későbbi tartás kívánt helyét. A tartási körülmények részletes leírása az 'A' és 'B' mellékletekben listázott fajok behozatala esetében szükséges. Erre azért van szükség, hogy az illetékes hatóságok meg tudjanak győződni a példányok későbbi megfelelő elhelyezéséről. ${ }^{604}$ Az élő példányok szállításáról kifejezetten szól az Alap Rendelet, mikor a szállítás körülményei tekintetében követelményeket ír elő: „,amennyiben élő példányokat szállítanak az Európai Unióba, onnan ki vagy azon belül, vagy egy ideig ott tartják azokat a tranzitszállitás vagy a kirakodás során, ezeket olyan módon kell felkészíteni, szállítani és gondozni, hogy a sérülés, az egészségkárosodás veszélye vagy a kegyetlen bánásmód kockázata minimális szinten maradjon, és állatok esetében az állatok szállítás közbeni

\footnotetext{
599 Végrehajtási Rendelet 54. cikk.

${ }^{600}$ Alap Rendelet 4. cikk (1) bekezdés d) pont.

${ }^{601}$ Alap Rendelet 4. cikk (1) bekezdés a) i) alpont és 4. cikk (2) bekezdés c) pont.

602 2015/870/EU Rendelet 3. pont a 338/97/EK tanácsi rendelet végrehajtására vonatkozó részletes szabályok megállapításáról szóló 865/2006/EK rendeletnek a vadon élő állat- és növényfajok kereskedelme tekintetében történő módosításáról. „A harmadik országok által kiadott exportengedélyek és reexport-bizonyítványok kizárólag abban az esetben fogadhatók el, ha az érintett harmadik ország illetékes hatósága kérésre hitelt érdemlö információkkal tud szolgálni arra vonatkozóan, hogy a példányokra a kérdéses fajok védelmére vonatkozó jogszabályok betartásával tettek szer."

${ }^{603}$ Végrehajtási Rendelet 66. cikk (6) bekezdés.

${ }^{604}$ Alap Rendelet 4. cikk (1) bekezdés c) pont és 4. cikk (2) bekezdés b) pont.
} 
védelméről szóló közösségi jogszabályok betartásra kerüljenek." ${ }^{605}$ Az Európai Unióban specifikusan, az élő állatok szállítására vonatkozóan is elfogadásra került a 2005/1/EK tanácsi rendelet az állatoknak a szállítás és a kapcsolódó műveletek közbeni védelmérö1. ${ }^{606}$ A CITES 16. CoP-n felülvizsgált 10.21-es határozata is ajánlásokat tesz, hogy milyen követelményeket kell a részes feleknek betartani az élő példányok szállítása során (IATA Live Animals Regulations (állatok), az IATA Perishable Cargo Regulations (növények) és a CITES guidelines for the non-air transport of live wild animals and plants/CITES irányelvek élö vadállatok és növények nem légi szállítására). Ezek az elöírások vonatkoznak az élő állatok, növények légi és nem légi úton történő szállítására is. ${ }^{607}$

Ha az importengedély kiállításra kerül, a kibocsátó hatóság a vadvilág kereskedelmi rendeletek és a tagállamnak a végrehajtásukra vonatkozó jogszabályi rendelkezései betartásának biztosítása céljából kikötéseket, feltételeket és elöírásokat adhat ki, amelyeket az érintett engedély tartalmaz. ${ }^{608} \mathrm{Az}$ importengedélyek érvényességi időtartama nem haladhatja meg a 12 hónapot. A korábbiaknak megfelelően az importengedély azonban nem érvényes az exportáló vagy újraexportáló országból származó, megfelelő dokumentáció nélkül. ${ }^{609}$ A példányok Európai Unióba történő behozatala esetében az említett, harmadik országokból származó szükséges dokumentumok csak akkor tekinthetők érvényesnek, ha azokat az adott országban adták ki és onnan történő exportra vagy re-exportra használják fel az érvényességük utolsó napját megelőzően és azokat az EU-ba történő behozatalra használják legkésőbb hat hónappal a kiadásukat követően. Így itt a Rendelet hat hónapban maximálja az érvényességi időt. ${ }^{610}$ A lejárt, felhasználatlan vagy már nem érvényes importengedélyt, exportengedélyt, re-export bizonyítványt, vándorkiállítás-bizonyítványt vagy személyi tulajdon bizonyítványt a tulajdonos köteles haladéktalanul visszajuttatni az igazgatási hatóságnak. Az ilyen dokumentumoknak már nincsen jogi értéke. ${ }^{611}$

A tagállamok az Alap Rendelet alapján behozatali és kiviteli helyeket határoznak meg, így vámhivatalokat jelölnek ki az a Rendelet hatálya alá tartozó fajok Európai Unióba történő behozatalára vonatkozó ellenörzések és vámkezelés, valamint az Unióból történő

\footnotetext{
${ }^{605}$ Alap Rendelet 9. cikk (5) bekezdés.

${ }^{606}$ A Tanács 2005/1/EK rendelete 2004. december 22. az állatoknak a szállítás és a kapcsolódó müveletek közbeni védelméről, valamint a 64/432/EGK és a 93/119/EK irányelv és a 1255/97/EK rendelete módosításáról (HL L 3., 2005.1.5., 1-44. p.) CELEX-szám: 32005R0001.

${ }^{607}$ Conf. Res. 10.21 (Rev. CoP16)

${ }^{608}$ Végrehajtási Rendelet 8. cikk (1) bekezdés.

${ }^{609}$ Végrehajtási Rendelet 10. cikk (1) bekezdés.

${ }^{610}$ Végrehajtási Rendelet 14. cikk.

${ }^{611}$ Végrehajtási Rendelet 10 . cikk (6) bekezdés.
} 
kivitel elvégzésére. ${ }^{612} \mathrm{Az}$ importőrnek a fentiek alapján kijelölt vámhivatalhoz be kell nyújtania valamennyi szükséges iratot: az eredeti importengedélyt (1. formanyomtatvány); a tulajdonos példányát (2. formanyomtatvány) és ha az importengedélyben meg van adva, akkor az exportáló vagy re-exportáló országból származó bármely dokumentációt. ${ }^{613}$ A vámhatóságok elvégzik a szállítmányhoz kapcsolódó megfelelő ellenőrzéseket, különös tekintettel a szükséges iratokra. A jogszerü behozatal bizonyítékaként szolgál később a tulajdonos példánya. ${ }^{614}$

Amennyiben egy tagállam elutasít egy engedély vagy bizonyítvány megadása iránti kérelmet az Alap Rendelet célját érintő jelentős esetben, akkor késedelem nélkül tájékoztatja a Bizottságot az elutasításról és annak okairól. A Bizottság az információt továbbítja a többi tagállamnak a Rendelet egységes végrehajtásának biztosítása érdekében. A kérelmezőt értesíteni kell az elutasítás tényéről és annak indokairól. Az igazgatási hatóság ugyancsak értesíti az export vagy újrakivitel államát és a CITES Titkárságot, amennyiben az elutasítás oka a kiviteli vagy újrakiviteli dokumentációban keresendő. ${ }^{615}$ Az importengedély iránti kérelem elutasításának egyik oka lehet, ha a Bizottság kereskedelmet az érintett faj/fajok tekintetében felfüggesztette. Amennyiben a kérelem benyújtójának korábbiakban már utasították vissza kérelmét az érintett példányok vonatkozásában, erről az igazgatási hatóságit informálnia kell. ${ }^{616}$

A 'C' és 'D' mellékletekben felsorolt fajok tekintetében a rendeletek egyszerüsített szabályokat állapítanak meg, így importbejelentés szükséges és a megfelelő dokumentáció biztosítása. A szabályozás eltérésnek oka, hogy az utóbbi mellékletekben felsorol fajok számára elegendő a kisebb fokú védelem biztosítása.

Ha egy faj a 'C' mellékletben található és egyben a III. Függelékben is, az Egyezménynek megfelelően a kérelmezőnek az ország illetékes hatósága által kiállított kiviteli engedélyt kell bemutatnia arról, hogy a példányok beszerzése az érintett fajok megőrzésére vonatkozó nemzeti jogszabályokkal összhangban történt. ${ }^{617}$ Természetesen azonban az élő példányokra vonatkozó egyéb elöírások, amelyek a példányok jólétét szavatolják, a 'C' és 'D' mellékletek fajaira is vonatkoznak.

\footnotetext{
${ }^{612}$ Alap Rendelet 12. cikk (1) bekezdés.

${ }^{613}$ Végrehajtási Rendelet 22. cikk.

${ }^{614}$ Végrehajtási Rendelet 23. cikk.

615 Alap Rendelet 6. Engedélyek és bizonyitványok megadása iránti kérelmek elutasitása.

${ }^{616}$ Végrehajtási Rendelet 20. cikk (3) bekezdés.

${ }^{617}$ Alap Rendelet 4. cikk (3) bekezdés a) pont.
} 
A 'C' és 'D' mellékletekben felsorolt fajok importja tehát egyszerüsített eljárás alapján történik. Amennyiben az importőr biztosította a szükséges dokumentumokat, és a behozatal során a vámhatóság azokat megfelelőnek találja, a behozatal jogszerünek minősül. Az eredeti és a tulajdonos példánya dokumentumok az igazgatási hatósághoz kerülnek. A tulajdonos példánya később visszakerül, amely a jogszerü behozatal bizonyítékaként szolgál. ${ }^{618}$

\section{V.5.4. Az Európai Unión belüli kereskedelem}

Az Európai Unión belüli kereskedelem magában foglalja az egy tagállamon belül történő és az egyes uniós tagállamok közötti kereskedelmi tevékenységet. A belső piac miatt a tagállamok között - főszabály szerint - nincsen határellenőrzés, így a vadvilági termékeket szabadon lehet szállítani és azokkal kereskedni az EU határain belül. ${ }^{619}$ Mivel azonban az egyes fajoknak magas szintü védelmet kívánnak biztosítani, korlátozásokat volt szükséges bevezetni, föként az 'A' mellékletben szereplö fajok tekintetében.

Az Alap Rendelet kereskedelmi tevékenység ellenőrzésére vonatkozó előírásai között szerepel az a korlátozás, hogy tilos az 'A' mellékletben felsorolt fajok példányainak kereskedelme és szállítása. Kereskedelmi tevékenységnek minősül a fajok megvétele, vételi ajánlat tétele, kereskedelmi célú beszerzése, kereskedelmi célú árubemutatása, kereskedelmi nyereséget célzó felhasználása és eladása, kereskedelmi áru jellegü tartása, eladási ajánlata vagy eladásra történő szállítása. ${ }^{620}$ A tilalom alapvetően vonatkozik az 'A' és a 'B' mellékletben listázott fajokra is, azonban a 'B' melléklet tekintetében egy kivétel kerül megállapításra. A 'B' mellékletben felsorolt fajok esetében a fenti tilalom nem kerül alkalmazásra, „ha az érintett tagállam illetékes hatósága számára bizonyítani lehet, hogy az ilyen példányok beszerzése és - amennyiben azok a Közösség területén kívülről származnak - behozatala a vadon élő állat- és növényfajok megőrzésére vonatkozó egyéb közösségi jogszabályokkal összhangban történt."

Az élő egyedek szállítására vonatkozóan speciális szabályok kerültek kialakításra. Az 'A' melléklet fajai tekintetében, ha élő egyedek szállítására kerül sor, ahhoz szükséges a tagállam (ahol az egyed elhelyezkedik) igazgatási hatóságának előzetes felhatalmazása és a megfelelő igazolás kiállítása. Az igazgatási hatóság csak abban az esetben bocsátja ki az

\footnotetext{
${ }^{618}$ Reference Guide, 2017. 48. p.

${ }^{619}$ Reference Guide, 2017. 101. p.

${ }^{620}$ Alap Rendelet 8. cikk (1) bekezdés.

${ }^{621}$ Alap Rendelet 8. cikk (5) bekezdés.
} 
igazolást, ha a tudományos hatóság megbizonyosodott arról, hogy a rendeltetési helyen az élő példány számára tervezett elhelyezés annak fennmaradása és gondozása céljából megfelelö. ${ }^{622}$

Amennyiben a kereskedelemi tevékenységek ellenőrzésére vonatkozó szabályokat ( 8 . cikk) fogságban született vagy nevelt, illetve mesterségesen szaporított példányokra kell alkalmazni, a 'A' mellékletben felsorolt fajok védelmét a 'B' mellékletben listázott fajok példányaira alkalmazható elő́rásokkal összhangban kell megvalósítani. ${ }^{623}$

A főszabály az, hogy a 'B', 'C' és 'D' mellékletekben felsorolt fajok példányainak tartásához vagy szállításához nem szükséges engedély vagy igazolás. Azonban bármely uniós tagállam dönthet úgy, hogy korlátozza meghatározott egyedek tartását, különösen az 'A' mellékletben listázott fajok élő példányai tekintetében. ${ }^{624}$ Hasonlóan, a 'B', 'C' és 'D' mellékletekben felsorolt példányokkal folytatott kereskedelmi tevékenység nem engedélyköteles az EU-n belül, amennyiben legálisan kerültek megszerzésre és behozatalra. Utóbbiak igazolására azonban meghatározott esetekben dokumentáció biztosítása szükséges. Emiatt javasolt az import dokumentáció másolatának vagy a jogszerü megszerzés más bizonyítékának megőrzése (mint a nemzeti CITES igazgatási hatóságnak az igazolása). ${ }^{625}$

Az EU-n belüli kereskedelmi tilalom alól is kivételek kerültek meghatározásra, amelyeket a Végrehajtási Rendelet tartalmaz. Így az Alap Rendelet 8. cikkének (1) és (3) bekezdése alól általános mentességet élveznek a megjelölt esetek. Így a külön mellékletben meghatározott fajok fogságban született, illetve szaporított példányai és azok hibridjei esetében, feltéve, hogy a megjegyzéssel ellátott fajok példányait megfelelően megjelölték; és növényfajok mesterségesen szaporított példányai esetében; valamint olyan megmunkált példányok esetében, amelyeket több mint ötven évvel korábban szereztek meg, mint az Alap Rendelet több mint 50 évvel korábban beszerzett, megmunkált példányokra vonatkozó rendelkezése. ${ }^{626}$

Az általános kivételeken túl számos speciális kivétel is meghatározásra került a belső kereskedelmi tilalom alól, meghatározott feltételek alapján, az 'A' mellékletben meghatározott fajok tekintetben. A mentességek és eltérések lehetőségét a Végrehajtási Rendelet

\footnotetext{
${ }^{622}$ Alap Rendelet 9. cikk (2) bekezdés a) pont.

623 Alap Rendelet 7. cikk (1) bekezdés a) pont.

${ }^{624}$ Alap Rendelet 8. cikk (2) bekezdés. „A tagállamok megtilthatják példányok tartását, különösen az A. mellékletben felsorolt fajok élö állatainak esetében."

${ }^{625}$ Reference Guide, 2017. 101. p.

${ }^{626}$ Végrehajtási Rendelet 62. cikk 1-2-3.
} 
XV. Fejezete tartalmazza. Ezek az eltérések biztosíthatják a kivételeket a belső kereskedelem alól, tudományos intézetek javára, szavatolhatja az általános mentességet és tenyésztők számára készíthet előzetesen kiadott bizonylatok lehetőségét biztosíthatja ${ }^{627} \mathrm{~A}$ vadon élő állat- és növényfajok megörzésére vonatkozó egyéb uniós jogszabályok követelményeivel összhangban, a kereskedelmi tilalom alól esetenként eltérés engedélyezhető azon tagállam igazgatási hatósága által kiállított ide vonatkozó bizonyítványa révén, amelyben a példányok találhatók, amennyiben a példányok az Alap Rendeletben meghatározott esetek alá tartoznak. Például több mint 50 évvel korábban beszerzett, megmunkált példányok vagy egy állatfajnak fogságban született vagy nevelt példányai, vagy egy növényfajnak mesterségesen szaporított példányai, vagy ilyen példányok részei vagy származéka. ${ }^{628}$ Ezek a kivételek lehetővé teszi az utóbbi fajok példányainak belső kereskedelmét, bizonylat kiadása alapján, eseti alapon. A bizonylatok az Alap Rendelet szabályai szerint kerülnek kiadásra.

Másrészt az utazó kiállítások céljából kiállított bizonylatok használhatók belső kereskedelemi bizonylatokként, engedve a tartónak, hogy a mellékletekben felsorolt fajok példányit kereskedelmi célzattal bemutassa. Azonban a kivétel csak akkor él, ha a példányok fogságban születtek, mesterségesen szaporították őket vagy a tartó bizonyítani tudja, hogy a példányok jogszerüen kerültek behozatalra EU-ba vagy megszerzésre az EU területén, mielőtt a faj listázásra került volna az A vagy C1-es mellékletekben vagy az I-es Függelékben. ${ }^{629}$ A következő táblázat részletesen összefoglalja, hogy milyen dokumentációs követelményeket kell teljesíteni az Európai Unióban az egyes mellékletekbe sorolt fajok kereskedelmének esetében.

Ahogyan korábban arra már történt utalás, nem volt cél a kereskedelemre vonatkozó dokumentációs és engedélyezi szabályok kimerítő részletezése. Azonban a fenti import és egyéb rendelkezések ismertetése előrevetíti, hogy milyen sokrétü és bonyolult feltételekkel történhet a vadvilági kereskedelemre vonatkozó rendeletek alapján kivitelezett tevékenység. Nem meglepő, hogy a CITES és az uniós szabályok állami végrehajtása nagy terhet ró a tagállami hatóságokra.

\footnotetext{
${ }^{627}$ Végrehajtási Rendelet XV. Fejezet 59-63. cikkek.

${ }^{628}$ Alap Rendelet 8. cikk (3) bekezdés b) és d) pontok.

${ }^{629}$ Reference Guide, 2017. 105. p.
} 


\begin{tabular}{|c|c|c|c|}
\hline $\begin{array}{l}\text { Kereskede- } \\
\text { lem típusa }\end{array}$ & Melléklet & $\begin{array}{c}\text { Szükséges dokumentumok } \\
\text { (A dokumentumokat a kereskedelmi } \\
\text { tevékenység lefolytatása előtt be kell } \\
\text { szerezni és azokat a megfelelő vám- } \\
\text { hatóságnak be kell mutatni az EU- } \\
\text { ba/EU-ból történő kereskedelemhez) }\end{array}$ & $\begin{array}{c}\text { Az Alap } \\
\text { Rendelet } \\
\text { megfelelő } \\
\text { szakasza }\end{array}$ \\
\hline \multirow{4}{*}{$\begin{array}{c}\text { Import } \\
\text { (behozatal) }\end{array}$} & $\mathbf{A}$ & $\begin{array}{l}\text { A rendeltetési hely szerinti tagállam } \\
\text { igazgatási hatósága által kiállított be- } \\
\text { hozatali engedély és az export állam } \\
\text { által kibocsátott export engedély vagy } \\
\text { újrakiviteli bizonyítvány. }\end{array}$ & $4(1)$ \\
\hline & B & $\begin{array}{l}\text { A rendeltetési hely szerinti tagállam } \\
\text { igazgatási hatósága által kiállított be- } \\
\text { hozatali engedély és az export állam } \\
\text { által kibocsátott export engedély vagy } \\
\text { újrakiviteli bizonyítvány. }\end{array}$ & $4(2)$ \\
\hline & $\mathbf{C}$ & $\begin{array}{l}\text { Az export szerinti állam által kiállított } \\
\text { kiviteli engedély, újrakiviteli bizonyít- } \\
\text { vány vagy eredetigazolás (tekintettel } \\
\text { arra, hogy az export állam tekintetében } \\
\text { a faj szerepel-e a CITES III. Függelé- } \\
\text { kében) és importőr által tett importbe- } \\
\text { jelentés a behozatali vámhivatalban. }\end{array}$ & $4(3)$ \\
\hline & D & $\begin{array}{l}\text { Importbejelentés elözetesen a behoza- } \\
\text { tali vámhivatalban. }\end{array}$ & $4(4)$ \\
\hline \multirow{4}{*}{$\begin{array}{l}\text { Export } \\
\text { (kivitel) }\end{array}$} & $\mathbf{A}$ & $\begin{array}{l}\text { A kivitel szerinti EU tagállam által ki- } \\
\text { állított exportengedély és a célállam ál- } \\
\text { tal kibocsátott importengedély. (Utóbbi } \\
\text { akkor szükséges, ha a faj a CITES I. } \\
\text { Függelékében listázott.) }\end{array}$ & $5(1)-(2)$ \\
\hline & B & $\begin{array}{l}\text { A kivitel szerinti EU tagállam által ki- } \\
\text { állított exportengedély. }\end{array}$ & \multirow{2}{*}{$5(4)$} \\
\hline & $\mathbf{C}$ & $\begin{array}{l}\text { A kivitel szerinti EU tagállam által ki- } \\
\text { állított exportengedély. }\end{array}$ & \\
\hline & $\mathbf{D}$ & Nincs szükség dokumentációra. & \\
\hline \multirow{4}{*}{$\begin{array}{c}\text { Re-export } \\
\text { (újrakivitel) }\end{array}$} & $\mathbf{A}$ & $\begin{array}{c}\text { Az újrakivitel szerinti EU tagállam ál- } \\
\text { tal kiállított újrakiviteli bizonyítvány } \\
\text { és a célállam által kibocsátott import- } \\
\text { engedély. (Utóbbi akkor szükséges, ha } \\
\text { a faj a CITES I. Függelékében listá- } \\
\text { zott.) }\end{array}$ & $\begin{array}{c}5(1), 5(3), \\
5(5)\end{array}$ \\
\hline & B & $\begin{array}{l}\text { Az újrakivitel szerinti EU tagállam ál- } \\
\text { tal kiállított újrakiviteli bizonyítvány. }\end{array}$ & $5(4)-(5)$ \\
\hline & $\mathbf{C}$ & $\begin{array}{l}\text { Az újrakivitel szerinti EU tagállam ál- } \\
\text { tal kiállított újrakiviteli bizonyítvány. }\end{array}$ & $4(4)-(5)$ \\
\hline & D & Nincs szükség dokumentációra. & \\
\hline
\end{tabular}

${ }^{630}$ 4. táblázat: szerző saját fordítása, szerkesztése. Forrás: Reference Guide, 2017. 22-23. p. 


\section{Konklúzió: a vadvilággal kapcsolatos büntetendő cselekmé- nyek elleni küzdelem eszközei - sarokpontok a védett fajok megőrzésében}

„A vadvilággal kapcsolatos büncselekmények túlmutatnak a természetvédelem határain; ugyancsak fenyegetik a nemzeti és regionális biztonságot, a fenntartható fejlödést akadályozzák és tüzelik a korrupciót." 631

A legfontosabb következtetések a következö pontokban foglalom össze.

A) Bár a természet elleni büncselekmények közé sorolható vadvilággal kapcsolatos büntetendő cselekmények pontos fogalma nem került eddig megalkotásra egyetlen nemzetközi jogi instrumentumban sem, annak lényegi elemei és jellemzői meghatározhatók. Ezentúl minden vonatkozó egyezmény, kormányközi és nem kormányközi nemzetközi szervezet kialakított sajátos fogalmakat, hogy pontosan mit értenek a vadvilággal kapcsolatos büntetendő cselekmények körén.

B) Mivel a vadvilággal kapcsolatos büncselekmények szorosan kötődnek a szervezett bünözéshez és a korrupcióhoz, törekedni kell arra, hogy az államok csatlakozzanak a releváns nemzetközi egyezményekhez, illetve azok végrehajtása érdekében hatékony nemzeti intézkedéseket tegyenek.

C) A biológiai sokféleség megőrzése érdekében kidolgozott természetvédelmi terveket aláássa a vadvilágot károsító kiaknázás és jogellenes kereskedelmi tevékenység. Sok esetben a korrupció és az eltérő társadalmi normák, valamint az igazságosság eszméjének hiánya segíti elő a jogellenes cselekmények kivitelezését. Ezért mindenképpen törekedni kell az olyan jogszabályok kidolgozására, amelyek figyelemmel vannak a helyi sajátosságokra, a fejlődő államok igényeire.

D) A vadvilággal kapcsolatos büncselekmények egyik köre és típusa valóban a transznacionális szervezett bünözés keretében valósul meg, azonban a vonatkozó instrumentumok tételesen nem térnek ki erre. Így nem elvetendő a korrupció és szervezett bünözés elleni

${ }^{631}$ Crawford Allen, Igazgató, America and Wildlife Crime Idézet forrása: https://www.traffic.org/what-we-do/projects-and-approaches/wildlife-crime/ (2019. 03. 09.) „Wildlife crime goes beyond conservation issues, it is also a threat to national and regional security, a barrier to sustainable human development and a fuel for corruption" 
egyezmények kiegészítése, akár jegyzőkönyvi szinten a vadvilággal kapcsolatos büncselekmények és kereskedelem eseteivel.

E) A CITES tagságát tekintve gyakorlatilag univerzális egyezménynek tekinthető, azonban annak hatékony végrehajtása még várat magára. Emiatt támogatni kell a kevesebb erőforrással rendelkező részes feleket, hogy a fajmegörzési tervek keretében hatékony és célravezető megoldásokat dolgozzanak ki és hajtsanak végre nemzeti szinten. A támogatás ki kell, hogy terjedjen mind a pénzügyi-, mind a humánerőforrások fejlesztésére, beleértve a szakértői bázis támogatását. Kiemelt kérdéskör a szakértelem biztosítása, amely kiterjed a határon szolgálatot teljesítő tisztek képzésétől, az igazságszolgáltatásban dolgozó jogászokig.

F) Amennyiben az Egyezménynek való megfelelés kérdését vizsgáljuk, célravezetőnek tekinthető a kereskedelmi felfüggesztések alkalmazása, azonban figyelemmel kell lenni arra, hogy a fejlődő államokat, amelyek eleve kevesebb erőforrással rendelkeznek, ne sújtsák aránytalan mértékben és a szankciók helyett a helyes alkalmazáshoz vezető eszköztárat részesítsék elönyben.

G) Sürgős intézkedéseket igényel a társadalmi tudatosság javítása, amely lehetővé teszi, hogy a magánemberek is szabálykövető módon vásároljanak vadvilági termékeket, vagy csökkenjen a kereslet. A társadalmi tudatosság csak hosszú évek munkájával fejleszthető, leginkább a felmenő generációk tekintetében, azonban elkerülhetetlen a figyelemfelhívó programok szervezése és a megfelelő információk elérhetővé tétele és rendelkezésre bocsátása.

H) Az egyes államokban alkalmazott hátrányos jogkövetkezményeket tekintve, a részes államok között nagy különbségeket találhatunk, különösen a kiszabható szankciók tekintetében. A bünelkövetők által kihasznált ,forum-shopping” lehetőségét csökkentené, sőt ki is zárná, ha a vadvilágot károsító cselekmények egységesen bűncselekményi minősítést kapnának, komoly jogkövetkezményekkel (például: szabadságvesztés-büntetés, magas összegü pénzbüntetés, kitiltás). Differenciálni kell a nemzetközi szinten elkövetett és a biológiai sokféleséget negatívan érintő cselekményeket, amelyek a legtöbb esetben öszszefonódnak a szervezett bűnözéssel is. Továbbá, a különösen veszélyezetetett fajok esetében szigorú intézkedéseket kell alkalmazni, a felelősségrevonás mértékét is figyelembevéve. 
I) A vadvilággal kapcsolatos büncselekmények és az egyes térségek destabilizációja között már megállapított a szoros összefüggés. Éppen ezért törekedni kell a társadalmi, gazdasági és környezeti hatásokat együttesen kezelő programok és tervek kidolgozására, különösen a természeti erőforrások felhasználásával kapcsolatosan.

J) A vadvilággal kapcsolatos büntetendő cselekmények körére a megfelelő és alkalmazandó jogi eszközök rendelkezésre állnak, így a hangsúly a végrehajtás és a hatékonyság kérdésére esik.

Az értekezés első fő célkitüzése a releváns terminológia magyar nyelvbe történő átültetése volt, hogy az megfeleljen mind a tudomány, mind pedig a nyelvhelyesség követelményinek. Ennek eredményeképpen történt meg a vadvilággal kapcsolatos büntetendő cselekmények fogalmának elkülönítése a ténylegesen büntetöjogilag szankcionált büncselekményektől.

A környezet elleni bűncselekmények századunk egyik legnagyobb kihívása a nemzetközi közösség számára. Az egyik fő természetvédelmi célkitűzés, a biodiverzitás védelme és az annak érdekében foganatosított intézkedések hatékony megvalósítását nagyban akadályozzák az olyan jogellenes tevékenységek, mint a szabályok megsértésével végzett kiaknázás, bevétel, vadászat. Nem véletlen, hogy az utóbbi évtizedben a környezet elleni bűncselekmények a nemzetközi érdeklődés központjába kerültek. Ezen túlmenően, a vadvilággal kapcsolatos büntetendő cselekményeket és az illegális vadvilági kereskedelmet a nemzetközi közösség kiemelt kérdésként kezeli. A jogellenes (szabályok megkerülésével vagy megsértésével véghezvitt) kereskedelem a vadvilággal kapcsolatos büncselekmények legtipikusabb formája. A CITES 1973-as aláírása óta eltelt több mint négy évtizedben a veszélyeztetett fajok védelme nélkülözhetetlenné vált. A jog eszköztárában megjelennek a nemzetközi, uniós és állami/tagállami szabályozási szintek is, amelyek egymásra épülve és egymást kiegészítve igyekeznek minél magasabb védelmet nyújtani. Azonban az államok és a nemzetközi közösség erőfeszítéseit kiegészíti a nem kormányzati szektor tevékenysége, olyan szervezetek által, akik pontos, megbízható információkat biztosítanak a jelenség valódi mértékéről. Továbbá az NGO szektor eltérő - elsősorban természetvédelmi szempontokat megjelenítő - nézőpontot képvisel az egyes politikai döntésekkel, valamint jogi normák megalkotásával kapcsolatosan. A vadvilággal kapcsolatos büntetendő cselekmény olyan komplex jelenség, amely átfogja a megszerzéstől, a szállításon át az eladásig a vadvilágból származó egyedekkel vagy a vadvilágból 
származó termékekkel folytatott minden tevékenységet. Így az már az orvvadászat, begyüjtés, kivétel, megszerzés cselekményeivel megvalósul, folytatódik az ilyen példányok vagy termékek akár többszöri eladásával, míg azok eljutnak a végső vásárlóhoz. A Washingtoni Egyezmény azon fajokra koncentrál, amelyek veszélyeztetettek és a kereskedelem árt vagy árthat a fennmaradás esélyeinek. A vadvilági kereskedelem kiemelt figyelmet érdemel, hiszen a határokon átlépő tranzakció biztosítja, hogy a forráshelyről a végső vásárlóig, a fogyasztóig eljusson a vadvilágból származó faj egyede vagy az utóbbiakból készült termék.

A nemzetközi szabályozás alapköve a Washingtoni Egyezmény a veszélyeztetett állat- és növényfajok nemzetközi kereskedelméről. A CITES 1975-ben lépett hatályba és azóta tizenhét CoP került megtartásra, ahol számos határozat, döntés került elfogadásra. ${ }^{632}$ Utóbbiak fő célja, hogy a viszonylag régen elfogadott nemzetközi szerződést a XXI. század kihívásai között is megfelelő hatékonysággal lehessen alkalmazni. Bár az elfogadott határozatok kötelező ereje többször megkérdőjeleződött, az államok jogkövetési magatartása mégis abba az irányba mutat, hogy a CITES részes felei igyekeznek azokat betartani. A határozatoknak nagyobb része foglalkozik egy-egy különösen veszélyeztetett faj kiemelt védelmével (pl. afrikai elefántok) és az Egyezmény gyakorlati megvalósulásának problémáival és a tudományos bizonytalanságból (pl. nomenklatúra) eredő kérdések rendezésével. A nemzetközi színtéren egyre több szervezet foglalkozik a környezet elleni bűncselekményekkel, amely azzal is magyarázható, hogy összetett jelenségről van szó, aminek az államokra és a társadalomra gyakorolt negatív hatásai is sokrétűek. Az utóbbi évtizedben mind az Egyesült Nemzetek Szervezete, mind az ENSZ Környezeti Programja is többsoron tárgyalásra tüzte a jelenséget és a jogellenes vadvilági kereskedelmet. A Kereskedelemi Világszervezet, mint a nemzetközi kereskedelmi kapcsolatok legfontosabb letéteményese, több szempontból is érintett a jelenséggel kapcsolatosan. Az olyan partikuláris nemzetközi szervezetek, mint a Gazdasági Együttmüködési és Fejlesztési Szervezet, a gazdaság és az államokra gyakorolt hatás szemszögéböl közelíti meg a kérdéskört.

Jelenleg nincsen egységesen elfogadott fogalma a vadvilággal kapcsolatos bűncselekményeknek. Azonban minden releváns nemzetközi szervezet és egyezmény meghatározza azt, adott helyzetben mit értenek a vadvilágot kársító cselekmények körén. Véleményem

${ }^{632}$ A 18. részes felek konferenciája 2018. augusztus 17. és 28. között, Genfben lesz. Mivel jelen értekezés kézirata 2018. augusztus 10-én lezárásra kerül, a 18. CoP-n elfogadott döntések és határozatok már nem képzik a feldolgozott háttéranyag részét. 
szerint az egységes fogalom hiánya nem meglepő és annak megalkotása sem feltétlenül szükséges. Hiszen akkor, ha egy kifejezetten büntetőjogi szemszögből közelítő szervezetről van szó - mint a UNODC - akkor az olyan bünözéshez kötődő elemek kerülnek előtérbe, mint a szervezett bűnözéshez kötődő szálak és a korrupció. Más esetekben, ha a biológiai sokféleség megőrzése szempontjából vizsgáljuk a jelenséget, a minél szélesebb körű rendszertani megközelítés, a természetvédelmi szempontok és a veszélyeztetettség kerül előtérbe. Így elmondható, hogy a vadvilággal kapcsolatos büntetendő cselekmények általános jellemzői viszonylag egyszerủen megállapíthatók, egységes fogalomalkotásról nem beszélhetünk és az nem is feltétlenül szükséges. Ennek fényében került az értekezés keretében meghatározásra egy fogalom, valamint a cselekmények sokszínüségére tekintettel, fókuszpontban a kereskedelmi tevékenység elemzése és értékelése történt meg. Jelen dolgozat keretében vizsgálat tárgyát képezték a vadvilággal kapcsolatos büntetendő cselekmények jellemzői, különös tekintettel a nemzeti szintű büntetni rendelésre, a szervezett bűnözésre és a korrupcióra. Összegző jelleggel megállapítható, hogy bár a vadvilágot károsító cselekmények büntetni rendelése minden államban nemzeti szinten valósul meg, előtérbe helyezve a honos állat- és növényvilágot, a nemzetközi közösség szempontjából a határon átnyúló, általában a szervezett bünözés jegyeit is magán viselő tevékenységek bírnak jelentőséggel, ideértve a jogellenes vadvilági kereskedelmet is. Úgy is fogalmazhatnánk, hogy a környezet elleni büncselekmények és a vadvilággal kapcsolatos büntetendő cselekmények már az államon belül megvalósulnak, azonban a jogellenes kereskedelmi tevékenység hatására nemzetközivé válnak és a szervezett bünözés begyürüzése miatt kialakult egy új büncselekményi kategória, amely gyakran együtt jár más büncselekmények megvalósulásával is, ezen belül elsősorban a különböző korrupciós cselekményekkel. Bátran kijelenthető, hogy a vadvilággal kapcsolatos büntetendő cselekmények és tágabb értelemben a környezet elleni bűncselekmények a biodiverzitás és a környezeti erőforrások fenntartható kiaknázásának egyik legnagyobb gátjai.

Bár sokan a CITES-t az egyik legsikeresebb multilaterális környezeti egyezményként aposztrofálják, a rendszer gyengeségei mind a szakirodalomban, mind pedig a gyakorlatban megmutatkoztak. Ezért részletesen elemzésre kerültek azok a legfőbb problémák, amelyek az egyezmény elfogadása óta eltelt több mint négy évtized alatt felmerültek. Elsősorban a függelékekkel kapcsolatos kérdéseket elemeztem, egy esettanulmányon keresztül, az afrikai elefántok populációja tekintetében. Az afrikai elefántok populációja kapcsán kimondtam azt az alaptétel, hogy a fajok védelmére és a veszélyeztetett fajok 
megmentésére tett erőfeszítések nagyban összefüggést mutatnak a CITES védelmének szintjével. Továbbá, a Washingtoni Egyezményhez füzött fenntartások, mint fontos nemzetközi közjogi probléma feltárása következett. Részletes elemzésre kerültek a hatékonyság aspektusai és a kereskedelmi felfüggesztések, mint szankciós intézkedések. Itt kapcsolódott be a nemzetközi kereskedelmi jogi szemszög, a Kereskedelmi Világszervezet és a CITES együttműködése. Összességében elmondható, hogy a CITES-el szemben tett kritikai észrevételek ellenére sem lehet megnyugtatóan egyetérteni azon kijelentésekkel, amelyek az egyezményi rendszer teljes bukását aposztrofálják. Nyilvánvalóan beszámolhatunk a Washingtoni Egyezmény teljes érvényesülését gátló tényezőkről és valóban megállapíthatók a hatékonysághoz kötőtő problémák is. De utóbbiak leginkább az államok szintjén megjelenő erőforráshiányból és egyéb destabilizációs tényezőkből - például korrupció, gyenge kormányzat, alternatív társadalmi szabályok léte - erednek, mintsem a nemzetközi szabályozási rendszer hiányosságaiból. Így fontos az erőforrások aktivizálása, a fejlődő államok támogatása annak érdekében, hogy a biodiverzitás megőrzése érdekében kifejtett természetvédelmi intézkedések minél sikeresebben valósulhassanak meg. Együttesen szükséges a jog, a gazdaságtudomány és a fejlesztési stratégiákat felvonultató tudományterületek együttmüködése, természetesen a CITES állandó megújulása mellett, amely megvalósul a részes felek konferenciáin elfogadott döntéseket és határozatokon keresztül.

Mint a legtöbb multilaterális környezeti egyezmény, a CITES is tartalmaz a „hátrányos jogkövetkezményekre" vonatkozó rendelkezéseket, felvetve az egyéni felelősség kérdését. A környezet elleni büncselekmények minden állam saját, nemzeti szintü szabályozásában jelennek meg, egységes törekvésekröl talán csak az Európai Unióban beszélhetünk. A „hátrányos jogkövetkezmények” kifejezés nem feltételezi a bűncselekményi minősítést, így a CITES részes feleiben is változatos szankciók - a szabálysértésektől a tényleges bűncselekményekig - találhatók. A környezetet kársító cselekmények egyre nagyobb jelentőségre tesznek szert nemzetközi szinten is, ennek eredménye, hogy a Nemzetközi Büntetőbíróság is figyelemmel van az ilyen típusú cselekményekre ügyválasztása során. Azonban nem beszélhetünk nemzetközi szintü büncselekmény kialakulásáról, vagyis az egyéni felelösség elbírálása megmarad az állam igazságszolgáltatási szervezetrendszerén belül. A CITES tekintetében megfontolandó, hogy a vadvilágot károsító bűncselekmények jelentőségére tekintettel ösztönzzék a részes feleket az egységes bűncselekményi minősítés elfogadására és hatékony, súlyos és elrettentő szankciók alkalmazására. 
Az Európai Közösség saját szabályozása révén már az 1980-as évek elejére elérte a CITES által biztosított védelmi szintet. Az integrációs szervezet csatlakozása az Egyezményhez egy évtizedeken átívelő elképzelés volt, amely végül - a CITES gaboron-i módosításának hatálybelépése után - 2015-ben valósulthatott meg. Az Európai Unió kiterjedt vadvilági kereskedelem szabályozása nem csupán eléri, hanem túl is szárnyalja a Washingtoni Egyezmény által, részes feleivel szemben támasztott követelményeket. Ezen túlmenően a belső piac és a tagállamok közötti kereskedelem szükségessé teszi, hogy ne csak az Unióba történő behozatal vagy onnan történő kivitel, hanem a tagállamok közötti, belső kereskedelmi tevékenység is szabályozásra kerüljön. Az elsősorban rendeleti alapokon nyugvó szabályozást egészíti ki a Cselekvési Terv, amely irányt mutatott az EU által, a 17. CoP-n képviselt álláspont meghatározásánál is. Mára minden uniós tagállam részes fél a CITES-ben is, több esetben már az uniós csatlakozást megelőzően csatlakoztak a Washingtoni Egyezményhez, mint Magyarország is. Bár a vadvilági kereskedelemre elsősorban uniós szintű szabályozás alá esik, a részletek meghatározása és a végrehajtás nagy részben a tagállamokon múlik. Ezért minden tagállamnak különös figyelmet kell fordítani a megfelelő hatóságok létrehozására és fenntartására, valamint a belső szabályozását összehangolására a nemzetközi jogból fakadó és az uniós kötelezettségekkel. Véleményem szerint nem tehetünk különbséget aszerint, hogy az uniós szabályozás jobb vagy megfelelőbb, mint a nemzetközi szintű. Mindenképpen a hatékonyság szemszögéből kell megközelíteni a kérdést. A CITES egy környezeti tárgyú, univerzálisnak tekinthető nemzetközi egyezmény, azzal a célkitüzéssel, hogy elsősorban a gazdaság-kereskedelem szemszögéből védi a veszélyeztetett fajokat. A fő keretek kialakítása megtörtént az Egyezmény elfogadásával, de a végrehajtási eszközök pontosítása az államok, a részes felek kezében van. Utóbbi kapcsán mutatkozik meg az egyes országok közötti nagy erőforráskülönbégek szerepe a környezet- és természetvédelemben. Az Európai Unió ebből a szempontból elönyös helyzetben van, hiszen a tagállamok (az értekezés írásakor még 28-an) a fejlett államok közé sorolhatók. Az EU egységesen igyekszik a CITES szabályait meghatározni a tagállamok számára és széles körű normaalkotással védeni a gazdaságilag jelentős veszélyeztetett fajokat. A törekvések az EU Washingtoni Egyezményhez való csatlakozásával teljesedtek ki. Azonban igaz a megállapítás, hogy amennyiben a tagállamok nem biztosítanak megfelelő humán- és gazdasági erőforrásokat, a végrehajtás elmaradása miatt a szabályozás - legyen is az bármennyire szigorú - értelmét veszti. 
Záró gondolatként megjegyezném, hogy jelen értekezés a jog szemszögéböl közelített a vadvilágot károsító cselekményekhez, ezen belül is elsősorban a nemzetközi közjog és uniós jog szempontjából. Azonban nem szabad elfelejteni, hogy teremtett világunk egyetlen összefüggő egységet alkot és ha az egyik alkotóelemet elvesszük vagy megkárosítjuk, nem tudjuk milyen következményekkel kell majd szembenéznünk. A kihalási ráta egyre aggasztóbb mutatószámai, az eltűnő őserdők és élőhelyek, a biodiverzitás megállíthatatlannak tünő csökkenése mind elvezethetnek egy olyan ponthoz, ahonnan már nincs viszszatérés és beláthatatlan ökológiai következményekkel kell szembenéznie az emberiségnek. Ezért különösen fontos eszköz a jog, a mértékadó szabályozás létrehozása és elfogadása a nemzetközi közösség egyetértésével, de nem hunyhatunk szemet a társadalmi tudatosság és az egyéni szintű cselekvés kimagasló jelentősége fölött sem.

„Ha a természetet egyetlen, összefüggő szőttesként fogjuk fel, rögtön nyilvánvalóvá válik a sebezhetösége is. Minden kapcsolatban áll egymással. Ha egy szálat kihúzunk, az egész kárpit felbomolhat." ${ }^{633}$

${ }^{633}$ Andrea Wulf (1972-), történész-író. Idézet forrása: https://www.citatum.hu/szerzo/Andrea_Wulf (2019. 08. 01.) 


\section{Záró gondolatok}

„Föld nem a tulajdonunk, hozzá tartozunk.

Muszáj megosztanunk a vadvilággal." 634

A veszélyeztetett fajok kereskedelmi szabályozásának kérdéskörével először akkor találkoztam, amikor 2015 januárjában az éves ACUNS konferencián vettem részt, Bécsben. A nyomtatott formában kezembe akadt „Wildlife Crime Analytical Toolkit” bevezetett egy olyan nemzetközi jogi területre, amely mind elméleti, mind gyakorlati szinten is kihívásokat tartogat. Környezetvédelmi szakjogász tanulmányaim nagyban hozzásegítettek az értekezés megírásához. Igyekeztem az ökoszisztéma-felfogást követve, modern szemléletben, de a nemzetközi jogi iskola alapértékeit szem előtt tartva feldolgozni ezt a bonyolult, sok tekintetben bizonytalanságoktól övezett témakört. Állat- és természetvédelmi szemléletem további motivációt biztosított az értekezés megírásához. Azonban jogászként mindig szem előtt kell tartani egy téma feldolgozása során, amiképpen a CITES is a fenntartható kiaknázást helyezi előtértbe, ne tegyen elfogulttá személyes meggyőződésem a téma kutatásakor.

Az értekezésem alapjaként szolgáló témával immáron több éve foglalkozom, azonban még mind a mai napig találkozom új megoldandó kérdésekkel, nemzetközi jogi problémákkal. A biológiai sokféleség csökkenése napjaink egyik fenyegetö környezeti kérdése, amely csak nemzetközi szintủ összefogással állítható meg.

Álláspontomban a vadvilággal kapcsolatos büncselekmények és a jogellenes, vadvilágból származó egyedekkel vagy termékekkel folytatott kereskedelem tipikusan abba a témakörbe tartozik, amikor a nemzetközi közösség bár sokat foglalkozik egy kérdéssel, jelenséggel, de a hatékony végrehajtás elmaradása miatt sok elképzelés pusztán üres terv marad. Természetesen, fontos, hogy több színtéren, nemzetközi szervezetekben, államközi tárgyalásokon minél szélesebb körben foglalkozzanak természetvédelmi és megörzési kérdésekkel. Azonban mivel az ellenőrzés, végrehajtás és kikényszerítés szinte teljes egészében az államok akaratán, képességein és lehetőségein múlik, a hangsúlyt a belső szabályozás nemzetközi szabályokkal való megfelelőségére, a vám- és egyéb rendőrségi szervek megerősítésére és a hatékony megvalósítására kell fordítani.

\footnotetext{
${ }^{634}$ Steve Irwin (1962-2006) ausztrál zoológus, természettudós, televíziós személyiség Idézet forrása: IRWIN, STEVEN - IRWIN, TERRI: The Crocodile Hunter: The Incredible Life and Adventures of Steve and Terri. NAL Trade, 2002.

„We don't own the planet Earth, we belong to it. And we must share it with our wildlife."
} 


\section{Irodalomjegyzék}

\section{KÖNYVEK, TANULMÁNYOK}

Alagappan, Meena: United States' Enforcement of the Convention on International Trade in Endangered Species of Wild Fauna and Flora, 10 Nw. J. Int'l L. \& Bus. 541 (1990) pp. 541-568.

Bajomi Bálint: A biológiai sokféleség és jelentősége. KOVÁSZ, VIII. évfolyam, 1-4. szám Tavasz - Tél (2004.) pp. 7-14.

Beyerlin, Ulrich - Stoll, Peter-Tobias - Wolfrum, Rüdliger: Conclusions drawn from the Conference on Ensuring Compliance with MEAs. Studies on the Law of Treaties: Ensuring Compliance with Multilateral Environmental Agreements. Brill | Nijhoff., Vol. 2. (2006.) pp. 359-369.

Blutman László: Az Európai Unió joga a gyakorlatban. II. Kiadás. HVG-Orac, Budapest, 2013.

Borbíró Andrea - Gönczöl Katalin - Kerezsi Klára - Lévay Miklós: Kriminológia. Kriminológiai Elmélet: bünözésmagyarázatok, A kortárs kriminológia tárgya és vizsgálati területei. Budapest, 2016.

Bowman, Michael: A Tale of Two CITES: Divergent Perspectives upon the Effectiveness of the Wildlife Trade Convention. Review of European Community \& International Environmental Law Vol. 22 (3) (2013). pp. 228-238.

Bruhács János: Nemzetközi jog I. Általános Rész. Dialog Campus Kiadó, 2008. BudapestPécs.

Burns, William C.: CITES and the Regulation of International Trade in Endangered Species of Flora: A Critical Appraisal, 8 Dick. J. Int'1 L. 203 (1990) pp. 203-223.

Farer, Tom (szerk.): Transnational Crime in the Americas An Inter-American Dialogue Book. Routledge, New York. 1999.

Farkas Csamangó Erika: Környezetjogi szabályozások. Egyetemi Jegyzet, SZTE ÁJTK, Üzleti Jogi Intézet. 2017. 
Fuchs, Christine: Convention on International Trade in Endangered Species of Wild Fauna and Flora (CITES) - Conservation Efforts Undermine the Legality Principle. German L. J. Vol. 09. No. 11. pp. 1565-1596.

Gardner, B. Delworth: Globalization, Free Trade and Environmental Quality. Hoover Press: Anderson/Prosperity. DP0 HANDEP0400 rev1. pp. 109-142.

Gates, Bill: Business @ the Speed of Thought: Succeeding in the Digital Economy. Grand Central Publishing. NY, 1999.

Görgényi Ilona: A környezetvédelmi büntetöjog megújulása az új évezredben. Miskolci Jogi Szemle, 6. évf. 2001. különszám pp. 94-105.

Görgényi Ilona: Környezetvédelmi büntetőjog az európai elvárásokra figyelemmel. Agrár- és Környezetjog. 2018. 25. szám pp. 46-80.

Guymon, CarrieLyn Doningen: International Legal Mechanisms for Combating Transnational Organized Crime: The Need for a Multilateral Convention. Berkeley J. Int'L. 53. (2000) pp. 53-101.

Harris, Michael R.: The Role of Law, Society and Ethics within Wildlife Importing Countries. Quinninpiac L. Rev. Vol 33. (2015.) pp. 515-536.

Harrison, Joseph R.- Roberts, David L.- Hernandez-Castro Julio C.: Assessing the extent and nature of wildlife trade on the darkweb. Conservation Biology Vol. 30. 2016. augusztus pp. 900-904.

Hitch, Scott: Losing elephant wars: CITES and the Ivory Ban. Georgia Journal of International and Comparative Law, Vol. 27, Issue 1 (1998), pp. 167-198

H. Roth, Harald - Merz, Günter (Szerk.): Wildlife Resources: A Global Account of Economic Use. Springer-Verlag, Berlin Heidelberg, 1997.

Hunter, David - Salzman, James - Zaelke, Durwood: International Environmental Law and Policy. 5. kiadás University Casebook Series, Founation Press, St. Paul, USA, 2015. Irwin, Douglas A.: Free trade under fire. Princeton, N.J.: Princeton University Press. 4. kiadás, 2015.

Irwin, Douglas A.: Free trade under fire. The Milken Institute Review. Second Quater, 2002. pp. 69-82. 
Kende Tamás - Nagy Boldizsár - Sonnevend Pál - Valki László: Nemzetközi jog. Wolters Kluwer Kft. Budapest, 2014.

Kovács József: Környezeti etika. Világosság. 9-10. szám, 2008. pp. 75-108.

Kovács Péter: A nemzetközi jog fejlesztésének lehetőségei és korlátai a nemzetközi biróságok gyakorlatában. Pázmány Péter Katolikus Egyetem Állam- és Jogtudományi Kar, Budapest, 2010.

Legislative Development: Convention on International Trade in Endangered Species of Wild Fauna and Flora. Law and Policy in International Business. 6. (1974) pp. 12111228.

Lemieux, Andrew M., Clarke, Ronald V.: The International Ban on Ivory Sales and its Effects on the Elephant Poaching in Africa. Brit. J. Criminol. Vol. 49. 2009. pp. 451-471.

L. Gore, Meredith - Ratsimbazafy, Jonah - L. Lute, Michelle: Rethinking Corruption in Conservation Crime: Insights from Madagascar. Conservation Letters 6:6 2013. nov./dec. pp. 430-438.

Matthias Finger - Thomas Princen: Environmental NGOs in World Politics: Linking the Local and the Global. NGOs and CITES as a biodiversity regime. Routledge, New York, 2001.

Mascia, Michael B. - Blundell, Art: Discrepancies in Reported Levels of International Wildlife Trade. Conservation Biology. Vol. 19. (2005. december) pp. 2020-2025.

Navid, Daniel B.: Trade in Endangered Species: The Washington Convention: First Meeting of the Conference of the Parties. Environmental Policy and Law, Vol. 2 (1976) pp. 167-170.

Neumayer, Eric: The WTO and the environment: its past record is better than critics believe, but the future outlook is bleak. Global environmental politics. 2004. Vol. 4. (3.) pp. $1-8$.

Neumayer, Eric: Multilateral environmental agreements, trade and development: issues and policy options concerning compliance and enforcement. Consumer Unity \& Trust Society, Jaipur (India). (2002). pp. 1-61. (LSE Research Online (2012.): http://eprints.1se.ac.uk/30858/)

Protecting Endangered Species. Environmental Policy and Law, Vol. 3 (1977) 56. 
Reeve, Rosalind: Enhancing the International Regime for Protecting Endangered Species: the Example of CITES. Max-Planck-Institut für ausländisches öffentliches Recht und Völkerrecht. ZaöRV 63 (2003) pp. 333-354. (http://www.zaoerv.de/63_2003/63_2003_2_a_333_354.pdf)

Roberts, David L.- Hernandez-Castro Julio C: Bycatch and illegal wildlife trade on the dark web. Oryx, The journal of Flora and Fauna International. 2017. pp. 393-394.

Sand, Peter H.: Endangered Species, International Protection. Max Planck Encyclopedia of Public International Law. Oxford University Press. Vol. 3. (2012.) Online elérhető: 2017. március pp. 423-429.

Sand, Peter H.: Enforcing CITES: The Rise and Fall of Trade Sanctions. Review of European Community \& International Environmental Law Vol. 22 (3) (2013). pp. 251-263.

Sand, Peter H.: Sanctions In Case of Non-Compliance And State Responsibility: Pacta Sunt Servanda - Or Else. Making Law Work: Environmental Compliance and Sustainable Development. Cameron May Ltd., London, Vol. 1. (2005.) pp. 259-271.

Sands, Philippe: Principles of International Environmental Law. Third Edition. Cambridge University Press, Cambridge, 2012.

Santos, Anna - Satchabut, Thitikan - Vigo Trauco, Gabriela: Do Wildlife Tade Bans Enhance or Undermine Conservation Efforts? Applies Biodiversity Perspective Series, 1(3) 2011. pp. 1-15.

Sommer, Julia: Environmental Law-Making by International Organisations. MaxPlanck-Institut für ausländisches öffentliches Recht und Völkerrecht. ZaöRV 63 (1996.) pp. 628-667. (http://www.zaoerv.de/56_1996/56_1996_3_a_628_66 7.pdf)

Stewart, Gwyneth G.: Enforcement Problems in the Endangered Species Convention: Reservations Regarding the Reservation Clauses. Cornell International Law Journal. Vol. 14. (1981.) pp. 429-455.

Sterling, Claire: Thieves' World: the threat of the global network of organised crime. Simon and Schuster, NY, 1994.

Sussis, Matt: Endangered at the Border. Animal Trafficking Closely Tied to Drug, Human Trafficking. Center for Immigration Studies, 2018. augustus (https://cis.org/sites/default/files/2018-08/sussis-animals.pdf) 
van Uhm, Daan P. - Moreto, William: Corruption Within the Illegal Wildlife Trade: A Symbiotic and Antithetical Enterprise. Brit. J. Criminol. Vol. 58. 2018. pp. 864-885.

Voight, Christina: Rule of Law for Nature, New Dimension and Ideas in Environmental Law. Cambridge University Press, Cambridge, 2013.

Warchol, Greg L. Zupan, Linda L. Clack, Willie: Transnational Criminality: an analysis of the illegal wildlife market in Southern Africa. International Criminal Justice Review. Vol 13. (2003.) pp. 1-27.

White, Rob - Heckenberg, Diana: Green Criminology: An Introduction to the Study of Environmental Harm. Routledge, NY, USA, 2014.

Zimmerman, Mara E.: The Black Market for Wildlife: Combating Transnational Organized Crime in the Illegal Wildlife Trade. Vanderbilt Journal of Transnational Law Vol. 36, no. 5. (2003. november) pp. 1957-1689.

\section{NEMZETKÖZI SZERZŐDÉSEK}

Agreement for the conservation of the flora and fauna of the Amazonian territories. 1975. (1976.) Lima UNTS 1056127 p.

Basel convention on the control of transboundary movements of hazardous wastes and their disposal. 1989. (1992.) UNTS Vol. 1673. 57. p. Bázeli Egyezmény a hulladékok határokon túlra történő szállításának és ártalmatlanításának ellenőrzéséről. Kihirdette: 101/1996. (VII. 12.) Korm. Rendelet

Convention for the Conservation of the Biodiversity and the Protection of Priority Wilderness Areas in Central America. 1992. (1994.) Managua

Convention for the Protection of Birds Useful to Agriculture. 1902. (1905.) Párizs A mezőgazdaság számára hasznos madarak védelméről szóló egyezmény. Kihirdette: 1906. évi I. törvény

Convention on Biological Diversity. 1992. (1993.), Rio de Janeiro UNTS 1760 79. p. A biológiai sokféleségről szóló egyezmény. Kihirdette: 1995. évi LXXXI. törvény

Convention on International Trade in Endangered Species of Wild Fauna and Flora. Egyezmény a veszélyeztetett vadon élő állat- és növényfajok nemzetközi 
kereskedelméröl. Kihirdette: 2003. évi XXXII. törvény [Magyarország vonatkozásában 1985. augusztus hó 27. napján lépett hatályba.] 1973. (1975.)

Convention on the Protection of Environment through Criminal Law. 1998. november 04. ETS No. 172. (Magyarország nem írta alá és nem részes fél az egyezményben.)

Convention on the Prevention of Marine Pollution by Dumping Wastes and Other Matter. 1972. (1975.) UNTS Vol. 1046. 139. p. A hulladékkal és egyéb anyagokkal való tengerszennyezés megelőzéséről szóló egyezmény. Kihirdette: 1976. évi 20. tvr.

Convention on the Transboundary Effects of Industrial Accidents. 1992. (2000.) UNTS Vol. 2105. 457. p. Az Egyesült Nemzetek Szervezetének Európai Gazdasági Bizottsága keretében létrejött, az Ipari Balesetek Országhatáron Túli Hatásairól szóló, Helsinkiben, 1992. március 17-én kelt Egyezmény. Kihirdette: 128/2001. Korm. Rendelet

Convention on Wetlands of International Importance Especially as Waterfowl Habitat (Ramsar Convention) 1971. (1975.) A nemzetközi jelentőségű vadvizekről, különösen mint a vízimadarak tartózkodási helyéröl szóló, Ramsarban, 1971. február 2-án elfogadott egyezmény és a Kiegészítő Jegyzőkönyvek: 1982., 1987. Kihirdette: 1979. évi 28. tvr. A Jegyzőkönyvekkel egységes szerkezetben: 1993. évi XLII. törvény.

Council of Europe Convention on Laundering, Search, Seizure and Confiscation of the Proceeds from Crime and on the Financing of Terrorism. 2005 Council of Europe Treaty Series - No. 198. Európa Tanács pénzmosásról, a büncselekményből származó jövedelmek felkutatásáról, lefoglalásáról és elkobzásáról, valamint a terrorizmus finanszírozásáról szóló, Varsóban, 2005. május 16-án kelt Egyezménye. Kihirdette: 2008. évi LXIII. törvény.

International Convention on Civil Liability for Oil Pollution Damage. UNTS Vol. 973. 3. p. 1969. (1975.) Protocol: 1992. (1996.) Amendment: 2000. (2003.) Kihirdette: 2007. évi IX. törvény International Convention on Civil Liability for Bunker Oil Pollution Damage. 2001. (2008.) a bunkerolaj-szennyezéssel okozott károkkal kapcsolatos polgári jogi felelősségről szóló egyezmény. Kihirdette: 2007. évi CLXV. törvény

International Agreement for the Regulation of Whaling. 1937. (Kiegészítő Jegyzőkönyv: 1938., 1945.), London

International Convention for the Regulation of Whaling 1946. (1946.) Washington A bálnavadászat nemzetközi szabályozásáról szóló egyezmény. 
International Tropical Timber Agreement 1994. (1997.) UNTS Vol. 1955, p. 81., Intermational Tropical Timber Agreement 2006. (2011.) UNTS Vol. 2797. p. 75. A trópusi faanyagokról szóló nemzetközi megállapodás. Kihirdette: 14/2012. (II.16.) Korm. rendelet

Marrakesh Agreement Establishing the World Trade Organization. A Kereskedelmi Világszervezetet létrehozó Marrakeshi Egyezmény Kihirdette: 1998. évi IX. törvény

North Pacific Fur Seal Convention, 1911. (1911.) Washington

OECD Convention on Combating Bribery of Foreign Public Officials in International Business Transactions. A külföldi hivatalos személyek megvesztegetése elleni küzdelemről szóló Egyezmény. 1997.(1999.) Kihirdette: 2000. évi XXXVII. törvény.

Protocol against the Illicit Manufacturing of and Trafficking in Firearms, Their parts and Components and Ammunition, supplementing the United Nations Convention against Transnational Organized Crime. Az Egyesült Nemzetek keretében létrejött, a nemzetközi szervezett bünözés elleni egyezményt kiegészítő, a tüzfegyverek, részeik, alkotóelemeik és lőszereik tiltott előállítása és kereskedelme elleni jegyzőkönyve 2001. (2005.)

Protocol against the Smuggling of Migrants by Land, Sea and Air, supplementing the United Nations Convention against Transnational Organized Crime. Az Egyesült Nemzetek keretében, Palermóban, 2000. december 14-én létrejött, a nemzetközi szervezett bűnözés elleni Egyezménynek a migránsok szárazföldön, légi úton és tengeren történő csempészete elleni fellépésről szóló Jegyzőkönyve. 2000. (2004) Kihirdette: 2006. évi CIII. tv.

Protocol of 1978 relating to the International Convention for the prevention of pollution from ships, 1973. 1978. (1983.) UNTS 1340 (p.61), 1341 (p.3) A hajókról történő szenynyezés megelőzéséről szóló 1973. évi egyezmény és az ahhoz csatolt 1978. évi Jegyzőkönyv (MARPOL 1973/1978.) Kihirdette: 2001. évi X. törvény

Protocol to Prevent, Suppress and Punish Trafficking in Persons, Especially Women and Children, supplementing the United Nations Convention against Transnational Organized Crime. Az ENSZ nemzetközi szervezett bünözés elleni egyezményének (Palermói Egyezmény) az emberkereskedelem, különösen a nők és gyermekek kereskedelme megelőzéséről, visszaszorításáról és büntetéséről szóló Jegyzőkönyve. 2000. (2003) Kihirdette: 2006. évi CII. törvény 
The Carpathian Convention 2003. (2006.) Kijev A Kárpátok védelméről és fenntartható fejlődéséről szóló keretegyezmény. Kihirdette: 306/2005. (XII. 25.) Korm. rend.

The Convention on Migratory Species of Wild Animals. (Bonn Convention) 1979. (1983.) Bonn A vándorló vadon élő állatfajok védelméről szóló egyezmény. Kihirdette: 1986. évi 6. tvr.

The Convention Relative to the Preservation of Fauna and Flora in the Natural State. 1933. (1933.) London

The Montreal Protocol on Substances that Deplete the Ozone Layer 1987. (1989.) UNTS Vol. 1522. 30. p. Az ózonréteget lebontó anyagokról szóló, Montreálban 1987. szeptember 16-án aláírt jegyzőkönyv. Kihirdette: 35/1990. (II. 28.) MT Rendelet

United Nations Convention against Corruption. Az Egyesült Nemzetek korrupció elleni egyezménye. 2003. (2005.) Magyarországon kihirdette: 2005. évi CXXXIV. törvény

United Nations Convention against Illicit Traffic in Narcotic Drugs and Psychotropic Substances. Az Egyesült Nemzetek Szervezete keretében a kábítószerek és pszichotrop anyagok tiltott forgalmazása elleni, 1988. december 20-án, Bécsben kelt Egyezmény. 1988. (1990.) Kihirdette: 1998. évi L. törvény.

United Nations Convention against Transnational Organized Crime. 2006. évi CI. törvény az Egyesült Nemzetek keretében, Palermóban, 2000. december 14-én létrejött, a nemzetközi szervezett bünözés elleni Egyezmény kihirdetéséről 2000. (2003.)

United Nations Convention on the Law of the Sea. ENSZ tengerjogi egyezménye. 1982. (1994.) UNTS Vol. 1833, 3. p. (Magyarországon nincs kihirdetve.)

United Nations Framework Convention on Climate Change. 1992. (1994.) New York UNTS 1771107 p. Az Egyesült Nemzetek Szervezetének Klímaváltozásról szóló Keretegyezménye.

Vienna Convention on the Law of Treaties. A szerződések jogáról szóló Bécsi Egyezmény Kihirdette: 1987. évi 12. tvr. 1969. (1980.)

Vienna Convention for the Protection of Ozone Layer. 1985. (1988.) UNTS Vol. 1513. 293. p. Egyezmény az ózonréteg védelméről. Kihirdette: 31/1990. (II. 16.) MT rendelet 


\section{NEMZETKÖZI SZERVEZETEK HATÁROZATAI, DÖNTÉSEI}

\section{1. CITES}

Res. Conf. 4.25 (Rev. CoP14) Reservations

Res. Conf. 6.7 Interpretation of Article XIV, paragraph 1, of the Convention

Res. Conf. 8.3. (Rev. CoP13) Recognition of the benefits of trade in wildlife

Res. Conf. 8.4 (Rev. Co15) National laws for implementation of the Convention

Res. Conf. 9.20 (Rev. CoP15) Guidelines for evaluating marine turtle ranching proposals submitted pursuant to Resolution Conf. 11.16 (Rev. CoP15)

Res. Conf. 9.21 (Rev. CoP13) Interpretation and application of quotas for species included in Appendix I

Res. Conf. 10.9 Consideration of proposals for the transfer of African elephant populations from Appendix I to Appendix II

Res. Conf. 10.10 (Rev. CoP17) Trade in elephant specimens

Res. Conf. 10.13 (Rev. CoP15) Implementation of the Convention for timber species

Res. Conf. 10.14 (Rev. CoP16) Quotas for leopard hunting trophies and skins for personal use

Res. Conf. 10.21 (Rev. CoP16) Transport of live specimens

Res. Conf. 11.3 (Rev. CoP17) Compliance and enforcement

Res. Conf. 11.7 Conservation of and trade in musk deer

Res. Conf. 12.7 (Rev. CoP17) Conservation of and trade in sturgeons and paddlefish

Res. Conf. 12.8 (Rev. CoP17) Review of Significant Trade in specimens of Appendix-II species

Res. Conf. 12.11 (Rev. CoP16) Standard nomenclature

Res. Conf. 13.2 (Rev. CoP14) Sustainable use of biodiversity: Addis Ababa Principles and Guidelines

Res. Conf 13.4 (Rev. CoP16) Conservation of and trade in great apes

Res. Conf. 13.5 (Rev. CoP14) Establishment of export quotas for black rhinoceros hunting trophies

Res. Conf. 13.10 (Rev. CoP14) Trade in alien invasive species

Res. Conf. 14.4 Cooperation between CITES and ITTO regarding trade in tropical timber

Res. Conf. 14.6 (Rev. CoP16) Introduction from the sea

Res. Conf. 14.7 (Rev. CoP15) Management of nationally established export quotas 
Res. Conf. 15.2 Wildlife trade policy reviews

Res. Conf. 16.3 (Rev CoP17) CITES Strategic Vision: 2008-2020

Res. Conf. 16.6 (Rev. CoP17) CITES and livelihoods

Res. Conf. 16.7 (Rev. CoP17) Non-detriment findings

Res. Conf. 16.8 (Rev. CoP17) Frequent cross-border non-commercial movements of musical instruments

Res. Conf. 17.4 Demand reduction strategies to combat illegal trade in CITES-listed species

Res. Conf. 17.6 Prohibiting, preventing, detecting and countering corruption, which facilitates activities conducted in violation of the Convention

Res. Conf. 17.7 Review of trade in animal specimens reported as produced in captivity Res. Conf. 17.8 Disposal of illegally traded and confiscated specimens of CITES-listed species

Res. Conf. 17.9 Trade in hunting trophies of species listed in Appendix I or II

Res. Conf. 17.10 Conservation of and trade in pangolins

Res. Conf. 17.11 Conservation of and trade in helmeted hornbill

Res. Conf. 17.12 Conservation, sustainable use of and trade in snakes

Decision 15.57 Combating wildlife cybercrime

Decision 17.92 Combating wildlife cybercrime

Decision 17.93 Combating wildlife cybercrime

Decision 17.94 Combating wildlife cybercrime

Decision 17.95 Combating wildlife cybercrime

Decision 17.96 Combating wildlife cybercrime

\section{2. IUCN}

Res. 078 2016. november 07. Crimes against the environment

IUCN GA 1990 REC 040 Appendix I Reservations within CITES

\section{3. ENSZ KÖZGYÜLÉS}

A/RES/69/314 (2015. augusztus 19.) Tackling illicit trafficking in wildlife A/RES/70/301 (2016. szeptember 09.) Tackling illicit trafficking in wildlife A/RES/71/326 (2017. szeptember 28.) Tackling illicit trafficking in wildlife 


\section{4. ENSZ BizTONSÁGI TANÁCS}

S/RES/2198 (2015. január 29.) Security Council Renews Arms Embargo, Related Sanctions on Democratic Republic of Congo

S/RES/2262 (2016. január 27.) on the Central African Republic

Statement by the President of the Security Council 2015. június 21.

\section{5. ENSZ GAZDASÁgi ÉS SZOCIÁlis TANÁCSA}

Resolutions 2001/12 (2001. július 24.) Illicit trafficking in protected species of wild flora and fauna

Resolution 2003/27 (2003. július 22.) llicit trafficking in protected species of wild flora and fauna

Resolution 2008/25 (2008. július 24.) International cooperation in preventing and combating illicit international trafficking in forest products, including timber, wildlife and other forest biological resources

Resolution 2011/36 (2001. július 28.) Crime prevention and criminal justice responses against illicit trafficking in endangered species of wild fauna and flora

Resolution 2013/40 (2013. október 17.) Crime prevention and criminal justice responses to illicit trafficking in protected species of wild fauna and flora

\section{6. ENSZ KöRnyezeti Programja}

UNEP/EA.1/INF/19 (2014. május 21.) Information note by the secretariat on illegal trade in wildlife: the environmental, social and economic consequences for sustainable development

UNEP/EA.2/L.15/Rev.1. (2016. május 26.) Illegal Trade in Wildlife

UNEP Governing Council decision SS.VII/4. (2002) Compliance with and Enforcement of Multilateral Environmental Agreements

\section{7. ENSZ BÜNMEGELŐZÉSI ÉS BÜNTETŐ IGAZSÁGSZOLGÁLTATÁSI BIZOTTSÁGA}

Resolution 16/1 (2007. április 07.) International cooperation in preventing and combating illicit international trafficking in forest products, including timber, wildlife and other forest biological resources

Resolution 23/1 (2014 májusa) Strengthening a targeted crime prevention and criminal justice response to combat illicit trafficking in forest products, including timber 


\section{8. KERESKEDELMI VILÁGSZERVEZET}

TN/TE/S/5/Rev.6; WT/CTE/W/160/Rev.8 Matrix on trade-related measures pursuant to selected multilateral environmental agreements

Trade Facilitation Agreement, Kereskedelem Könnyítő Megállapodás, elfogadta a WTO Általános Tanácsa 2014 novemberében. A megállapodás 2017. február 22-én lépett hatályba.

\section{AZ EURÓPAI UNIÓHOZ KAPCSOLÓDÓ FORRÁSOK}

\section{1. RENDELETEK}

A Tanács 3626/82/EGK rendelete (1982. december 03) a CITES Közösségen belüli végrehajtásáról (HL L 384., 1982.12.31., 1-61. p.) CELEX-szám: 31982R3626 Érvényesség vége: 1996. 12. 31.

A Bizottság 3418/83/EGK rendelete a CITES Közösségen belüli végrehajtásához szükséges dokumentumok kérdéséröl (1983. november 28.) (HL L 344., 1983.12.7., 1-27. o.) CELEX-szám: 31983R3418 Érvényesség vége: 1997. 05. 31.

A Bizottság 939/97/EK rendelete (1997. május 26.) a veszélyeztetett állat- és növényfajok védelméről szóló 338/97 tanácsi rendelet részletes végrehajtásáról (HL L 140., 1997.5.30., 9-50. o.) CELEX-szám: 31997R0939 Érvényesség vége: 2001. 09. 21.

A Tanács 338/97/EK rendelete (1996. december 9.) a vadon élö állat- és növényfajok számára kereskedelmük szabályozása által biztosított védelemről (HL L 61., 1997.3.3., 1-69. p.) CELEX-szám: 31997R0338

A Bizottság 1808/2001/EK rendelete (2001. augusztus 30.) a vadon élő állat- és növényfajok számára kereskedelmük szabályozása által biztosított védelemről szóló 338/97/EK tanácsi rendelet végrehajtására vonatkozó részletes szabályok megállapításáról. (HL L 250., 2001.9.19., 1-43. p.) CELEX-szám:32001R1808 Érvényesség vége: 2006. 08. 08.

A Tanács 2005/1/EK rendelete 2004. december 22. az állatoknak a szállítás és a kapcsolódó müveletek közbeni védelméről, valamint a 64/432/EGK és a 93/119/EK irányelv és a 1255/97/EK rendelete módosításáról (HL L 3., 2005.1.5., 1-44. p.) CELEX-szám: 32005R0001. 
A Bizottság 865/2006/EK rendelete (2006. május 4.) a vadon élő állat- és növényfajok számára kereskedelmük szabályozása által biztosított védelemről szóló 338/97/EK tanácsi rendelet végrehajtására vonatkozó részletes szabályok megállapításáról (HL L 166., 2006.6.19., 1-69. p.) CELEX-szám: 32006R0865

A Tanács 1005/2008/EK rendelete (2008. szeptember 29.) a jogellenes, nem bejelentett és szabályozatlan halászat megelőzésére, megakadályozására és felszámolására irányuló közösségi rendszer létrehozásáról (HL L 286., 2008.10.29., 1-32. p.) CELEX-szám: 32008R1005

A Bizottság 1010/2009/EK rendelete (2009. október 22.) az 1005/2008/EK tanácsi rendelet alkalmazására vonatkozó részletes szabályok megállapításáról (HL L 280., 2009.10.27., 5-41. p.) CELEX-szám: 32009R1010

A Bizottság 791/2012/EU végrehajtási rendelete (2012. augusztus 23.) a vadon élö állatés növényfajok számára kereskedelmük szabályozása által biztosított védelemről szóló 338/97/EK tanácsi rendeletben elöírt engedélyek, bizonyítványok és más okmányok mintáira vonatkozó szabályok megállapításáról és a 865/2006/EK bizottsági rendelet módosításáról (HL L 242., 2012.9.7., 13-45. p.) CELEX-szám: 32012R0791

A Bizottság 792/2012/EU végrehajtási rendelete (2012. augusztus 23.) a vadon élő állatés növényfajok számára kereskedelmük szabályozása által biztosított védelemről szóló 338/97/EK tanácsi rendeletben elöírt engedélyek, bizonyítványok és más okmányok mintáira vonatkozó szabályok megállapításáról és a 865/2006/EK bizottsági rendelet módosításáról (HL L 242., 2012.9.7., 13-45. p.) CELEX-szám: 32012R0792

A Bizottság 888/2014/EU végrehajtási rendelete (2014. augusztus 14.) egyes vadon élő állat- és növényfajok példányai Unióba történő behozatalának tilalmáról (HL L 243., 2014.8.15., 21-38. p.) Érvényesség vége: 2015. 05. 28. CELEX-szám: 32014R0888

A Bizottság 736/2015/EU végrehajtási rendelete (2015. május 7.) egyes vadon élő állatés növényfajok példányai Unióba történő behozatalának tilalmáról (HL L 271., 2017.10.20., 7-24. p.) Érvényesség vége: 2017. 11. 08. CELEX-szám: 32015R0736

A Bizottság 870/2015/EU rendelete (2015. június 5.) a 338/97/EK tanácsi rendelet végrehajtására vonatkozó részletes szabályok megállapításáról szóló 865/2006/EK rendeletnek a vadon élő állat- és növényfajok kereskedelme tekintetében történő módosításáról (HL L 142., 2015.6.6., 3-20. p.) CELEX-szám: 32015R0870 
A Bizottság (EU) 2017/128 rendelete (2017. január 20.) a vadon élö állat- és növényfajok számára kereskedelmük szabályozása által biztosított védelemről szóló 338/97/EK tanácsi rendelet módosításáról. (HL L 21., 2017.1.26., 1-98. p.) CELEX-szám: 32017R0128 Érvényesség vége: 2017. 01.26.

A Bizottság (EU) 2017/160 rendelete (2017. január 20.) a vadon élö állat- és növényfajok számára kereskedelmük szabályozása által biztosított védelemről szóló 338/97/EK tanácsi rendelet módosításáról. (HL L 27., 2017.2.1., 1-98. p.) CLEX-szám: 32017R0160

A Bizottság 1915/2017/EU végrehajtási rendelete (2017. október 19.) egyes vadon élő állat- és növényfajok példányainak az Unióba történő behozatalának tilalmáról (HL L 271., 2017.10.20., 7-24. p.) CELEX-szám: 32017R1915

A Bizottság 220/2019/EU rendelete (2019. február 6.) a vadon élö állat- és növényfajok számára kereskedelmük szabályozása által biztosított védelemröl szóló 338/97/EK tanácsi rendelet végrehajtására vonatkozó részletes szabályok megállapításáról szóló 865/2006/EK rendelet módosításáról (HL L 35., 2019.2.7., 3-27. p.) CELEX-szám: 32019R0220

\section{2. IRÁNYELVEK}

Az Európai Parlament és a Tanács 2008/99/EK irányelve (2008. november 19.) a környezet büntetőjog általi védelméről (HL L 328., 2008.12.6., 28-37. p.) CELEX-szám: 32008L0099

\section{3. HatározATOK, KerethatÁROZATOK}

Resolution of the Council of the European Communities and of the Representatives of the Governments of the Member States meeting within the Council of 17 May 1977 on the continuation and implementation of a European Community policy and action programme on the environment. 1977. május 17-i Tanácsi találkozó (HL C 139., 1977.6.13., 1-46. p.) CELEX-szám: 41977X0613

A Tanács 2003/80/IB kerethatározata (2003. január 27.) a környezet büntetőjog általi védelméről (HL L 29., 2003.2.5., 55-58. p.) CELEX-szám: 32003F0080

A Tanács (EU) 2015/451 határozata (2015. március 6.) az Európai Uniónak a veszélyeztetett vadon élő állat- és növényfajok nemzetközi kereskedelméről szóló egyezményhez 
(CITES) való csatlakozásáról (HL L 75., 2015.3.19., 1-3. p.) CELEX-szám: 32015D0451

JAVASLAT A Tanács Határozata veszélyeztetett vadon élő állat- és növényfajok nemzetközi kereskedelméről szóló egyezmény (CITES) részes felei konferenciájának a délafrikai Johannesburgban 2016. szeptember 24. és október 5. között megrendezendő 17. ülésére benyújtott bizonyos javaslatok tekintetében az Európai Unió által képviselendő álláspont meghatározásáról. COM(2016) 437 final, 2016/0200(NLE). Brüsszel, 2016. 07. 01. CELEX-szám: 52016PC0437

JAVASLAT: A Tanács határozata a veszélyeztetett vadon élö állat- és növényfajok nemzetközi kereskedelméröl szóló egyezmény részes felei konferenciájának 18. ülésén (CITES CoP18) az Unió nevében képviselendő álláspontról. COM(2019) 146 final, 2019/0083(NLE). Brüsszel, 2019. 03. 21. CELEX-szám: 52019PC0146

\section{4. KÖZLEMÉNYEK}

Communication from the Commission A Sustainable Europe for a Better World: A European Union Strategy for Sustainable Development (Commission's proposal to the Gothenburg European Council) 2001. 05. 15. COM(2001) 0264 final CELEX-szám: 52001DC0264

A Bizottság közleménye - A Biológiai sokféleség csökkenésének megállítása 2010-ig és azon túl - Az ökoszisztéma-szolgáltatások fenntartása az emberi jólét érdekében 2006. 05. 22. COM/2006/0216 végleges CELEX-szám: 52006DC0216

A Bizottság közleménye az Európai Parlamentnek, a Tanácsnak, a Gazdasági és Szociális Bizottságnak és a Régiók Bizottságának. Életbiztosításunk, természeti tőkénk: a biológiai sokféleséggel kapcsolatos, 2020-ig teljesítendő uniós stratégia 2011. 05.03. COM/2011/0244 végleges CELEX-szám: 52011DC0244

A Bizottság közleménye (2016/C 15/02) Útmutató dokumentum: Az orrszarvúszarvak kivitele, újrakivitele, behozatala és Unión belüli kereskedelme (HL C 15., 2016.1.16., 2 7. p.) CELEX-szám: 52016XC0116(01)

A Bizottság közleménye az Európai Parlamentnek, a Tanácsnak, az Európai Gazdasági és Szociális Bizottságnak és a Régiók Bizottságának A vadon élő állatok és növények 
jogellenes kereskedelme elleni uniós cselekvési terv. Brüsszel, 2016.2.26. COM (2016) 87 final CELEX-szám: 52016DC0087

A Bizottság közleménye (2017/C 154/06) Iránymutatásokat tartalmazó dokumentum: Az elefántcsont Európai Unión belüli kereskedelmét és újrakivitelét szabályozó uniós rendszer (HL C 154., 2017.5.17., 4-14. p.) CELEX-szám: 52017XC0517(01)

A Bizottság közleménye (2017/C 154/07) Iránymutatás a megmunkált példányokhoz a vadon élő állat- és növényfajok kereskedelmét szabályozó uniós rendeletek alapján (HL C 154., 2017.5.17., 15-26. p.) CELEX-szám: 52017XC0517(02)

\section{5. ÁlláSFOGLALÁSOK}

Az Európai Parlament 2014. január 15-i állásfoglalása a vadon élő növényekkel és állatokkal kapcsolatos büncselekményekről 2013/2747(RSP)

Az Európai Parlament 2016. november 24-i állásfoglalása a vadon élő állatok és növények jogellenes kereskedelme elleni uniós cselekvési tervről 2016/2076(INI) (HL C 224., 2018.6.27., 117-126. p.) CELEX-szám: 52016IP0454

Az Európai Parlament 2017. november 16-i állásfoglalása az EU-Afrika stratégiáról: a fejlődés fellendítése 2017/2083(INI) (HL C 356., 2018.10.4., 66-76. p.) CELEX-szám: 52017IP0448

Tervezet - A Tanács következtetései a vadon élő állatok és növények jogellenes kereskedelme elleni uniós cselekvési tervröl - A következtetések elfogadása 9721/1/16 REV 1 Brüsszel, 2016. június 13.

\section{6. ÜGYEK}

Sabine von Colson és Elisabeth Kamann v Land Nordrhein-Westfalen. Elözetes döntéshozatal iránti kérelem: Arbeitsgericht Hamm - Németország. Féfiak és a nők közötti egyenlő bánásmód - Munkavállalás. 14/83. sz. ügy ECLI:EU:C:1984:153

Commission of the European Communities $v$ French Republic. Importation of feline skins originating in Bolivia - Implementation in the Community of the Washington Convention. Az Európai Közösségek Bizottsága v Francia Köztársaság. C-182/89. sz. ügy Határozatok Tára: 1990 I-04337 ECLI:EU:C:1990:427 
Az Európai Közösségek Bizottsága v Európai Közösségek Tanácsa. Megsemmisítés iránti kereset - EU 29. cikk, az EU 31. cikk e) pontja, EU 34. cikk és EU 47. cikk - 2003/80/IB kerethatározat - Környezetvédelem - Büntetőjogi szankciók - A Közösség hatásköre Jogalap - EK 175. cikk 2005. szeptember 13. C-176/03. sz. ügy Határozatok Tára 2005 I-07879 ECLI:EU:C:2005:542

\section{KERESKEDELMI VILÁGSZERVEZET VITARENDEZÉSI TESTÜLETÉNEK DÖNTÉSEI}

United States - Import Prohibition of Certain Shrimp and Shrimp Products (USA v India, Malajzia, Thaiföld, Pakisztán) DS58.

United States - Measures Concerning the Importation, Marketing and Sale of Tuna and Tuna Products (USA v Mexico) DS381.

\section{NEMZETKöZI Jogi BIZOTTSÁg TERVEZETEI, JELENTÉSEI}

International Law Commission: Draft Articles on Responsibility of States for Internationally Wrongful Acts, 2001.

Report of the International Law Commission (Reservations). UN, New York, 2011. A/66/10/Add.1 124.p

\section{NEMZETKÖZI BíRÓSÁG DÖNTÉSEI ÉS TANÁCSADÓ VÉLEMÉNYEI}

Reservations to the Convention on Genocide, Advisory Opinion: I.C.J. Reports 1951, 15. p.

Pulp Mills on the River Uruguay (Argentina v. Uruguay), Judgment, I.C.J. Reports 2010, 14. p.

Whaling in the Antarctic (Australia v. Japan: New Zealand intervening), Judgment, I.C.J. Reports 2014, 226. p. 


\section{EGYÉB JOGFORRÁSOK}

292/2008. (XII. 10.) Korm. rendelet a veszélyeztetett vadon élö állat-és növényfajok nemzetközi kereskedelmét szabályozó nemzetközi és európai közösségi jogi aktusok végrehajtásának egyes szabályairól

2012. évi C. törvény a Büntető törvénykönyvről

\section{EGYÉB BÍRÓSÁGI DÖNTÉSEK}

A Pécsi Ítélőtábla, mint harmadfokú bíróság. Bhar.I.3/2017/4. szám. 2017. május 30.

\section{EGYÉB DOKUMENTUMOK}

\section{1. EURóPAi UNió KIADVÁNYAI}

A vadon élö fajok kereskedelmének szabályozása az Európai Unióban. Bevezetés a Washingtoni Egyezménybe és végrehajtásába az Európa Unióban. Luxembourg: Az Európai Közösségek Hivatalos Kiadványainak Hivatala, 2007. ISBN 978-92-79-05432-7

Fajarda Del Casillo, Teresa: Wildlife Crime in Spain. IP/A/ENVI/2015-10. 2016.

ILLES, ANDREA: Wildlife Crime in the United Kingdom. IP/A/ENVI/2015-10. 2016.

PAQUEL, KAMILA: Wildlife Crime in Poland. IP/A/ENVI/2015-10. 2016.

SOCTA: The EU Serious and Organised Crime Threat Assessment 2013.

StOerring, Dagmara: Wildlife Crime in Germany. IP/A/ENVI/2015-10. 2016.

VAN DeR GRIJP, NiCOLIEN: Wildlife Crime in the Netherlands. 2016. IP/A/ENVI/201510

\section{2. CITES}

CITES Strategic Vision: 2008-2020.

\section{3. ENSZ KERETÉBEN ELFOGADOTT JELENTÉSEK}

Brundtland Bizottság Közös Jövőnk c. jelentés, 1987. 
E/CN.15/2002/7 (2002. február 26.) Progress made in the implementation of Economic and Social Council resolution 2001/12 on illicit trafficking in protected species of wild flora and fauna. Report of the Secretary-General

E/CN.15/2005/10 (2005. március 17.) Illicit trafficking in protected species of wild flora and fauna. Report of the Secretary-General

\section{4. IUCN}

The Impact of IUCN Resolutions on international conservation efforts, an overview. IUCN, 2018. 1-19. p.

\section{5. Secretariat of the Commission for EnVironmental CoOperation of NORTH AMERICA (CEC)}

Free Trade and the Environment: The Picture Becomes Clearer. Commission for Environmental Cooperation of North America 2002. Preface V.

The Environmental Effects of Free Trade: Papers Presented at the North American Symposium on Assessing the Linkages between Trade and Environment (October 2000), CEC 2002.

\section{6. UNEP}

Nellemann, Christian (Szerk).: The Rise of Environmental Crime - A Growing Threat To Natural Resources Peace, Development And Security. A UNEP INTERPOL Rapid Response Assessment. UNEP, 2016.

UNEP-WCMX technical report. Comparison of EU decisions and CITES suspensions identification of any outstanding potential discrepancies. UNEP-WCMC Cambridge, 2016.

\section{7. TRAFFIC}

Briefing prepared by TRAFFIC for the European Commission. Overview of imortant international seizures in the European Union. January to December 2015 Compiled by TRAFFIC (April 2016, updated in March 2017)

European Union Wildlife Trade Reulations. Refernce Guide. TRAFFIC 2017. június 
Karin Berkhoudt: Focus on EU Enlargement és Wildilfe Trade: Review of CITES implementation in Candidate Countries. TRAFFIC Europe, 2002.

Katalin Kecse-Nagy, Dorottya Papp, Amelie Knapp and Stephanie von Meibom: Widlife Trade in Central and Eastern Europe. A review of CITES implementation in 15 countries. TRAFFIC Europe report, Budapest, Hungary, 2006.

Maylynn Engler - Rob Parry-Jones: Opportunity or threat? The role of the European Union in global wildlife trade. TRAFFIC Europe Report 2007., Brüsszel

Switching Channels. Wildlife trade routes into Europe and the UK. A WWF/TRAFFIC Report. 2002 decembere

\section{8. WTO}

Roberto Azevêdo, a WTO igazgatója: CITES and WTO Enhancing Cooperation for sustainable Development. WTO Titkárság, Svájc, 2015.

\section{9. WWF}

Trexler, M.C. - Kosloff, L.H.. The wildlife trade and CITES: an annotated bibliography for the Convention on International Trade in Endangered Species of Wild Fauna and Flora. Washington D.C. WWF, 1987.

\section{10.SAJTÓKÖZLEMÉNYEK}

Karmenu Vella, uniós biztos. Az EU a globális csúcstalálkozón a vadon élö állat- és növényfajok kereskedelmére vonatkozó szabályok további szigoritását szorgalmazza. Sajtóközlemény, Brüsszel, 2016. szeptember 23.

UN Press Release GA/SHC/3529 1999. október 18.

White Paper on Transnatinal Organised Crime. CDPC (2014) 11 Strabourg, 2014. május 28.

World Wildlife Crime Report, Trafficking in protected species. UNODC, United Nations, New York, 2016. 


\section{11. NEMZETKÖZI KONFERENCIÁKON ELFOGADOTT ELVEK, DOKUMENTUMOK}

Malawi Principles for the Ecosystem Approach. Malawi, 1998. január 26-28.

Recommendation of Section I on Crimes against the environment. Application of the general part, in: XV.th International Congress of Penal Law, Rio de Janeiro, 4-10 September 1994, International Review of Penal Law, 1995/1-2

Rio Declaration on Enviornment and Development, 1992.

\section{ONLINE FORRÁSOK}

\section{1. ONLINE CIKKEK, SZERZŐVEL}

Agence France-Presse: Norway boots whaling quota despite international opposition. https://www.theguardian.com/environment/2018/mar/07/norway-boosts-whaling-quotainternational-opposition

Alessandra Lehmen: ICC To focus on environmental crimes: a landmark move for international environmental law. 2017. 03. 21. https://www.expertguides.com/articles/icc-tofocus-on-environmental-crimes-a-landmark-move-for-international-environmentallaw/arljgbwe

Aaron Ross: Send in the troops: Congo raises the stakes on illegal mining. 2019. július 17. https://www.reuters.com/article/us-congo-mining-insight/send-in-the-troops-congoraises-the-stakes-on-illegal-mining-idUSKCN1UCOBS

Bennett O'Brien: Four major ways international trade has changed over the past one hundred years. 2015. 01. 13. http://www.tradeready.ca/2015/trade-takeaways/four-waysinternational-trade-changed-one-hundred-years/

Channing Mavrellis: The Illegal Wildlife Trade: Sample Retail Market Prices. 2017. 04. 26. https://www.gfintegrity.org/illegal-wildlife-trade-sample-retail-market-prices/ Damian Carrington: Illegal online sales of endangered wildlife rife in Europe. The Guardian, 2018. 05. 23. https://www.theguardian.com/environment/2018/may/23/illegalonline-sales-of-endangered-wildlife-rife-in-europe 
Damian Carrington: Pangolins thrown a lifeline at global wildlife summit with total trade ban. 2016. 09. 28. https://www.theguardian.com/environment/2016/sep/28/pangolinsthrown-a-lifeline-at-global-wildlife-summit-with-total-trade-ban

Edward Faulks: Al Qaeda profit from the trade of ivory. 2013. 12. 6. https://www.independent.co.uk/voices/comment/al-qaeda-profit-from-the-trade-of-ivory-8989151.html

Fuisz Tibor István: A vándorgalamb (ectopistes migratorius) kiirtása. 2015. december 02 .

https://mttmuzeum.blog.hu/2015/12/02/a_vandorgalamb_ectopistes_migratorius_kiir$\underline{\text { tasa }}$

Irene Banos Ruiz: Europe, a silent hub of illegal wildlife trade. 2017. 01. 20. http://www.dw.com/en/europe-a-silent-hub-of-illegal-wildlife-trade/a-37183459

James Bargent: Colombia Investigation Reveals Workings of Wildlife Traffickers. 2016.

07. 13. InSight Crime https://www.insightcrime.org/news/analysis/colombia-investiga$\underline{\text { tion-reveals-workings-of-wildlife-traffickers/ }}$

Jason Bittel: Last male Sumatran rhino in Malaysia dies. 2019. május 27.

https://www.nationalgeographic.com/animals/2019/05/last-sumatran-rhino-malaysia$\underline{\text { dies/ }}$

Jeffrey Gettleman: Elephants Dying in Epic Frenzy as Ivory Fuels War and Profits. NY Times, 2012. szeptember 03. https://www.nytimes.com/2012/09/04/world/africa/africaselephants-are-being-slaughtered-in-poaching-frenzy.html

John. E. Scanlon: Early reflections on eight years as Secretary-General of CITES, 20102018 2018. 04. 13. https://www.linkedin.com/pulse/early-reflections-eight-years-secretary-general-cites-scanlon-am/

John M. Sellar: Investigating and Prosecuting Wildlife Crime. How to enforce EU legislation on biodiversity and wildlife trafficking 2016. http://ec.europa.eu/environment/legal/law/4/pdf/investigation_and_prosecution_of_wildlife_crime.pdf.

John Vidal: The grey parrot and the race against Africa's wildlife extinction. The Observer, 2016. 09. 24. https://www.theguardian.com/environment/2016/sep/24/cites-endangered-species-meeting-johannesburg 
Mandy Zuo: '15,000 pangolins slaughtered' for 7 tonnes of scales seized in China https://www.scmp.com/news/china/society/article/2166083/15000-pangolins-slaughtered-7-tonnes-scales-seized-china

Michael Lemonick: The Ivory Wars: After a Seven Year Ban, Three African Nations Want to Sell Tusks. Will the Rest of the World Allow it? Time, 1997. 06. 16. http://content.time.com/time/magazine/article/0,9171,986539,00.html

Karimi, Faith: The world's last male northern white rhino is dead. Now what? CNN 2018. 03. 21.

https://edition.cnn.com/2018/03/20/africa/kenya-northern-white-rhino-dies-whats$\underline{\text { next/index.html }}$

Shasta Darlington: Illegal Mining, 'Worse Than at Any Other Time,' Threatens Amazon, Study Finds. The New York Times, 2018. december 10. https://www.nytimes.com/2018/12/10/world/americas/amazon-illegal-mining.html

Szalai Anikó, ijoten (Internetes Jogtudományi Enciklopédia), Nemzetközi szerzödések. 2018. https://ijoten.hu/szocikk/nemzetkozi-szerzodesek

Steve Boyes: The World's Most Traded Wild Birds? Senegal Parrots, color morphs, and the wild-caught bird trade... National Geographic, 2012. 01. 17. https://blog.nationalgeographic.org/2012/01/17/the-worlds-most-traded-wild-birds-senegal-parrots-colormorphs-and-the-wild-caught-bird-trade/

Tarján M. Tamás: 1944. július 22. Létrehozzák a Bretton Woods-i rendszert http://www.rubicon.hu/magyar/oldalak/1944_julius_22_letrehozzak_a_bretton_woodsi_rendszert/

Teresa Fajarda Del Casillo: Wildlife Crime in Spain. European Union, 2016. http://www.europarl.europa.eu/Reg-

Data/etudes/IDAN/2016/578962/IPOL_IDA(2016)578962_EN.pdf

\section{2. EGYÉB ONLINE FORRÁSOK}

Agenda and working documents

https://cites.org/eng/cop/07/doc/index.php

Amendments to Appendices I and II of the Convention https://cites.org/sites/default/files/eng/cop/10/E10-amendments.pdf 
Animals and Plant Committees

https://cites.org/eng/disc/ac_pc.php

Animal Welfare Institute, CITES CoP 16. Successes and failures

https://awionline.org/awi-quarterly/2013-spring/cites-cop16-successes-and-failures

Az orrszarvú szarva az élet kulcsa?

http://wwf.hu/archivum/2010ev/24/az-orrszarvu-szarva-az-elet-kulcsa

CITES Calendar

https://www.cites.org/eng/news/calendar.php

CITES Compliance and Enforcement Regime, expert meeting, 2012. Montreal

https://www.cbd.int/doc/meetings/abs/absem-comp-01/other/absem-comp-01-presentation-cites-en.pdf

CITES Secretariat Reservations

https://cites.unia.es/cites/file.php/1/trainers/Reservations.ppt

Conference of the Parties

https://cites.org/eng/disc/cop.php

Consequences of the transfer of the african elephant from Appendix I to Appendix II. Doc. 7.43.1.

https://cites.org/sites/default/files/eng/cop/07/doc/E07-43-01.pdf

Countries currently subject to a recommendation to suspend trade

https://www.cites.org/eng/resources/ref/suspend.php

Defining transnational organized wildlife crime

https://www.unodc.org/documents/data-and-analysis/wildlife/WLC16_Chapter_1.pdf

Draft Agenda $83^{\text {rd }}$ Meeting of the Committee on Trade in Wild Fauna and Flora. Brussels, Friday, 14 September 2018.

https://circabc.europa.eu/sd/a/94fcffa4-5672-45e9-908c-

a115a1832716/83_COM_agenda.pdf 
Draft Protocol for an International Court for the Environment 2011 februárja https://static1.squarespace.com/static/56c0ae80ab48de4417bd17fa/t/56d33d594c2f85dc 2df9ef37/1456684377825/Draft+Protocol+for+an+ICE.pdf

Elephants and ivory trade in southern Africa

https://cites.org/eng/cop/07/doc/index.php

Enforcement Group

http://ec.europa.eu/environment/cites/eg_en.htm

Environmental Ethics: Between Anthropocentrism and Ecocentrism.

http://home.iitk.ac.in/ anubha/CE213.pdf

Evironmental crimes

http://www.unicri.it/topics/environmental/

Environmental Dispute Resolution

https://pca-cpa.org/en/services/arbitration-services/environmental-dispute-resolution/

EU Accession to CITES

http://ec.europa.eu/environment/cites/gaborone_en.htm

Global Ocean Commission, Drivers of Decline

https://missionocean.me/drivers-of-decline/

How is CITES Financed?

https://cites.org/eng/disc/fund.php

ICCWC

https://www.cites.org/eng/prog/iccwc.php

ICE Coalition

http://www.icecoalition.org/

"Illegal" Logging and Global Wood Markets: The Competitive Impacts on the U.S. Wood Products Industry. Seneca Creek Associates, LLC, 2004.

http://www.unece.lsu.edu/responsible_trade/documents/2003-2006/rt03_036.pdf

Illegal, Unreported and Unregulated fishing (IUU fishing) 
http://www.fao.org/iuu-fishing/en/

In a blow to wildlife, China lifts a ban on the use of tiger and rhino parts 2018. október 29. https://www.worldwildlife.org/stories/in-a-blow-to-wildlife-china-lifts-a-ban-on-theuse-of-tiger-and-rhino-parts

IFAW: Disrupt: Wildlife Cybercrime. Uncovering the scale of online wildlife trade https://www.ifaw.org/sites/default/files/IFAW\%20-\%20Disrupt\%20Wildlife\%20Cybercrime\%20-\%20English.pdf

\section{IUCN Red List Background \& History}

https://www.iucnredlist.org/about/background-history

IvoryID

https://ivoryid.org/en/pages/about/how_it_all_began

Kenya's death penalty plan for poachers has stirred a hornet's nest 2018. május 22. http://theconversation.com/kenyas-death-penalty-plan-for-poachers-has-stirred-a-hornets-nest-96865

Leading tech companies unite to stop online wildlife traffickers 2018. 03. 07. https://www.ifaw.org/european-union/news/leading-tech-companies-unite-stop-onlinewildlife-traffickers

15. Life on land

https://www.un.org/sustainabledevelopment/biodiversity/

Links between corruption and wildlife crime highlighted at UN anti-corruption conference https://www.unodc.org/unodc/en/press/releases/2017/November/links-betweencorruption-and-wildlife-crime-highlighted-at-un-anti-corruption-conference.html

List of Parties to the Convention

https://www.cites.org/eng/disc/parties/index.php

Major impacts

https://www.illegal-logging.info/TOPICS/MAJOR-IMPACTS

MIKE Report Levels and trends of illegal killing of elephants in Africa to 31 December 2016 - preliminary findings. https://cites.org/sites/default/files/eng/prog/MIKE/MIKE_report_released_WWD_3Mar2017.pdf 
National laws for implementation of the Convention https://cites.org/sites/default/files/eng/prog/Legislation/CITES_national_legislative_status_table.pdf

National Wildlife Crime Unit, What is Wildlife Crime?

http://www.nwcu.police.uk/what-is-wildlife-crime/

NIAPs: National Ivory Action Plans https://cites.org/eng/news/pr/2016_trends_in_African_elephant_poaching_released_\%E2\%80\%93_CITES_MIKE_programme_03032017

Malaysia torches 2.8 tonnes of African pangolin scales 2018. december 06.

https://phys.org/news/2018-12-malaysia-torches-tonnes-african-pangolin.html

Model Law on International Trade in Wild Fauna and Flora. CITES Secretariat, 4. p.

https://cites.org/sites/default/files/eng/prog/Legislation/E-Model\%20law-updated-

clean.pdf

Names and addresses of the Management and Scientific Authorities designated by the Member States p. 59.

http://ec.europa.eu/environment/cites/pdf/list_authorities.pdf

Nemzetközi megállapodások és az EU külügyi hatáskörei

http://eur-lex.europa.eu/legal-content/HU/TXT/?uri=LEGISSUM:ai0034

Office of the Prosecutors. Policy paper on case selection and prioritisation 2016. szeptember 15 .

https://www.icc-cpi.int/itemsdocuments/20160915_otp-policy_case-selection_eng.pdf

Pangolins

https://www.pangolinsg.org/pangolins/

Prosecuting wildlife crimes in South Asia https://www.unodc.org/southeastasiaandpacific/en/2018/12/wildlife-trafficking/story.html

Reservations

https://cites.org/sites/default/files/eng/app/2017/E-Reserv-2017-07-05.pdf

Scale of illegal logging

https://www.illegal-logging.info/topics/scale-illegal-logging\%20

Signature and Ratification Status 
https://www.unodc.org/unodc/en/corruption/ratification-status.html

Standing Committee

https://cites.org/eng/disc/sc.php

Strategic Planform Biodiversity and the Aichi Biodiversity Goals

https://www.cbd.int/doc/strategic-plan/2011-2020/Aichi-Targets-EN.pdf

STOP Wildlife Crime

https://www.worldwildlife.org/pages/stop-wildlife-crime

Sustainable Development Goals

https://sustainabledevelopment.un.org/sdgs

The CITES Secretariat

https://cites.org/eng/disc/sec/index.php

The Differences between EU and CITES Provisions in a Nutshell http://ec.europa.eu/environment/cites/pdf/differences_b_eu_and_cites.pdf

The Ecosystem Approach. The Secretariat of the Convention on Biological Diversity, Montreal 2004.

https://www.cbd.int/doc/publications/ea-text-en.pdf

The environment: a specific concern https://www.wto.org/eng-

lish/thewto_e/whatis_e/tif_e/bey2_e.htm

The Millennium Development Goals Report, 2015. 57. p.

https://www.undp.org/content/dam/undp/library/MDG/eng-

lish/UNDP_MDG_Report_2015.pdf

The process — Stages in a typical WTO dispute settlement case

https://www.wto.org/english/tratop_e/dispu_e/disp_settlement_cbt_e/c6s10p1_e.htm

The scale of wildlife trafficking

http://ec.europa.eu/environment/cites/pdf/infographics/infographic-wildlife-scale.pdf

Tananyag

http://www.cites.hu/tanari.html

Trade in Ivory from African Elephants 
https://cites.org/sites/default/files/eng/cop/05/doc/E05-22.pdf

Transnational Organized Crime

https://www.unodc.org/ropan/en/organized-crime.html

Transparency International, How do you define corruption?

https://www.transparency.org/what-is-corruption\#define

UNODC Our Work

https://www.unodc.org/unodc/en/wildlife-and-forest-crime/our-work.html

UNODC: Transnational organized crime: the globalized illegal economy

https://www.unodc.org/toc/en/crimes/organized-crime.html

Urban Threats

https://www.nationalgeographic.com/environment/habitats/urban-threats/

UNODC Wildlife and forest crime

https://www.unodc.org/unodc/en/wildlife-and-forest-crime/overview.html

Welcome to ROUTES

http://routespartnership.org/

WILDLEX

https://www.wildlex.org/

Wildlife crime

https://cites.org/prog/iccwc.php/Wildlife-Crime

Wildlife crime assessed globally for the first time in new UNODC report

https://www.unodc.org/unodc/en/frontpage/2016/May/wildlife-crime-assessed-globallyfor-the-first-time-in-new-unodc-report.html

WTO Green Provisions https://www.wto.org/eng-

lish/thewto_e/whatis_e/tif_e/bey2_e.htm

WTO Mátrixok https://docs.wto.org/dol2fe/Pages/FE_Search/FE_S_S006.aspx?Data-

$\underline{\text { Source }=\text { Cat } \& q u e r y}=@$ Symbol=WT/CTE/W/160/*Language $=$ English $\&$ Con-

text=ScriptedSearches\&languageUIChanged=true 


\section{A FEJEZETEK KEZDETÉN ÉS VÉGÉN ELŐFORDULÓ IDÉZETEK FORRÁSAI}

- Kösznetnyilvánítás, 1. p.

Gerald Durrell: Catch me a Colobus c. könyvéböl. HarperCollins, 1996. 167. p.

„The world is as delicate and as complicated as a spider's web," he wrote. "If you touch one thread you send shudders running through all the other threads. We are not just touching the web. We're tearing great holes in it."

- Bevezető gondolatok, célkitüzések 7. p.

Sir David Frederick Attenborough https://www.citatum.hu/idezet/49783 (2019. 07. 23.)

- A vadvilággal kapcsolatos büntetendő cselekmények jelentősége 18. p.

SCHWEITZER, ALBERT 1923. Civilization and Ethics. Trans.: J. Naish. London: A \& C Black.

- A vadvilági kereskedelmet szabályozó egyezmény kritikai vizsgálata 89. p.

Jeff Rotman, WWF, www.naturepl.com

http://news.bbc.co.uk/2/hi/science/nature/8606011.stm (2019. 07. 20.)

- Az Európai Unió vadvilági kereskedelemre vonatkozó szabályozása 147. p.

Emma McClarkin: Using EU trade tools to combat wildlife trafficking. Press release. 2017.03. 02.

http://www.europarl.europa.eu/news/en/press-room/20170228IPR64299/using-eu-tradetools-to-combat-wildlife-trafficking (2019. 08. 10.)

- Konklúzió 183.p. és 189. p.

Crawford Allen https://www.traffic.org/what-we-do/projects-and-approaches/wildlifecrime/ (2019. 03. 09.)

Andrea Wulf https://www.citatum.hu/szerzo/Andrea_Wulf (2019. 08. 01.)

- Záró gondolatok 190. p.

Irwin, Steven - Irwin, Terri: The Crocodile Hunter: The Incredible Life and Adventures of Steve and Terri. NAL Trade, 2002. 196. p. 